\author{
UNIVERSIDADE DE SÃO PAULO \\ FACULDADE DE FILOSOFIA, LETRAS E CIÊNCIAS HUMANAS \\ DEPARTAMENTO DE HISTÓRIA \\ PROGRAMA DE PÓS-GRADUAÇÃO EM HISTÓRIA SOCIAL
}

\title{
A traição nas Canções de Gesta e o fortalecimento da monarquia capetíngia: França, 1180-1328
}

\section{VERSÃO CORRIGIDA}

Ademir Aparecido de Moraes Arias

Tese apresentada ao Programa de PósGraduação em História Social do Departamento de História da Faculdade de Filosofia, Letras e Ciências Humanas da Universidade de São Paulo, para obtenção do título de Doutor em História

Orientadora: Profa. Dra. Ana Paula Tavares Magalhães Tacconi

São Paulo

2016 
Nome: ARIAS, Ademir Aparecido de Moraes

Título: A traição nas Canções de Gesta e o fortalecimento da monarquia capetíngia: França, 1180-1328

Tese apresentada ao Programa de PósGraduação em História Social do Departamento de História da Faculdade de Filosofia, Letras e Ciências Humanas da Universidade de São Paulo, para obtenção do título de Doutor em História

Aprovado em:

Banca Examinadora

Prof. Dr. Instituição:

Julgamento: Assinatura:

Prof. Dr. Instituição:

Julgamento: Assinatura:

Prof. Dr. Instituição:

Julgamento: Assinatura:

Prof. Dr. Instituição:

Julgamento: Assinatura:

Prof. Dr. Instituição: Julgamento: Assinatura: 


\section{AGRADECIMENTOS}

À minha orientadora, $\operatorname{Prof}^{\mathrm{a}} \operatorname{Dr}^{\mathrm{a}}$ Ana Paulo Tavares Magalhães Tacconi, pela confiança em meu trabalho durante os anos de pesquisa e pela ajuda e força nos meus momentos de ansiedade. Sem isso eu não teria chegado ao dia de minha defesa.

À Prof ${ }^{\mathrm{a}}$ Dr $^{\mathrm{a}}$ Ivone Marques Dias, por ter me atraído para os estudos medievais, pelo incentivo e ajuda desde meus tempos de Graduação.

Ao Prof. Dr. José Roberto de Almeida Mello, por ter me indicado as Canções de Gesta como fonte de estudo, algo pelo qual me apaixonei e ainda sou fiel.

Ao Prof. Dr. Ruy de Oliveira Andrade Filho, por ter me trazido de volta ao mundo acadêmico, incentivando e conduzindo o meu Mestrado na UNESP de Assis e mostrando que eu podia ir além.

Ao Prof. Dr. Carlos Roberto Figueiredo Nogueira e à $\operatorname{Prof}^{a} \operatorname{Dr}^{a}$ Maria Cristina Correia Leandro Pereira, membros da minha Banca de Qualificação do Doutorado, pelos conselhos e ajuda em um momento de dúvidas sobre o caminho a seguir com o meu trabalho.

Ao Prof. Dr. José Rivair de Macedo, pela amizade antiga e pelo estímulo ao meu trabalho, mesmo à distância.

Ao colega de estudos Gesner Las Casas de Brito, pelo interesse em compartilhar idéias e pela ajuda quanto a textos os quais eu acreditava nunca teria acesso. O fato de ele gastar parte de seu tempo de estudo na Inglaterra para me auxiliar demonstra bem o valor de sua amizade e o quanto lhe devo.

Ao pessoal da Administração da FFLCH da USP e ao pessoal da Biblioteca Florestan Fernandes, em especial à Mariana, pela ajuda enquanto fui aluno desta Instituição.

Ao meu pai, minha mãe, minha irmã e meu sobrinho, pelo apoio, pela paciência e por aceitarem as escolhas que fiz. 


\section{RESUMO}

ARIAS, Ademir A. M. A traição nas Canções de Gesta e o fortalecimento da monarquia capetíngia: França, 1180-1328. 2015, 000 folhas. Tese (Doutorado) Faculdade de Filosofia, Letras e Ciências Humanas, Universidade de São Paulo, São Paulo, 2015.

A traição é um tema que temos estudado já faz algum tempo, utilizando como fontes as Canções de Gesta, um gênero literário poético corrente nas regiões que compunham o reino da França, entre o século XI e o século XV. O período áureo dessa poesia coincidiu com o governo da dinastia conhecida como dos "Capetos diretos", cujo reinado e sucessão de pai para filho persistiu sem interrupção de 987 até 1328.

Criadas e difundidas nos diversos senhorios territoriais da França, em especial no norte do reino, as Canções de Gesta tratavam em seus enredos de vários problemas de ordem moral e política vigentes na época. Em uma sociedade cuja coesão, ao menos na sua camada governante, era baseada na fidelidade e na criação de laços vassálicos, a traição constituía uma grave ameaça à estabilidade e à paz. Tanto a moral cristã quanto a moral cavaleiresca condenavam quem a praticasse, mas isso não evitou a sua constante ocorrência.

Estudamos cinco poemas épicos: a Chanson de Roland (c. 1100), o Girart de Vienne (1180-1185), o Renaut de Montauban (início do século XIII), o Gaydon (12301240) e o Jehan de Lançon (metade do século XIII). O Roland, sendo o mais antigo desses poemas, apresenta um monarca respeitado e difere dos poemas posteriores, cujos enredos valorizam os personagens conhecidos desde o século XIX como "Vassalos Rebeldes".

Da análise da traição nessa poesia e da relação entre vassalos e o rei pudemos extrair alguns pontos importantes. De início o ligado à questão vocabular, pois traïson $/$ traïtre / traïr designam um dos mais graves crimes ali descritos, graças a sua ligação com a tradição neotestamentária da entrega de Jesus por Judas Iscariotis, suplantando outros termos de origem latina ou não (proditio, felonie).

Nas Canções, a traição é dirigida primeiramente contra os barões e cavaleiros sendo os seus executores da mesma condição social de suas vítimas. Só tardiamente ela denomina um atentado contra o monarca. Outro ponto é a defesa, nos poemas, do direito à guerra ao senhor caso este não cumprisse suas obrigações de justiça para com seu vassalo. Assim, os heróis em luta contra Carlos Magno não eram mostrados pelo poeta como traidores e sim como vítimas de uma perseguição. Esses cavaleiros conservavam o respeito pelo seu senhor e aspiravam ser perdoados e reintegrados à corte régia.

A responsabilidade pelas traições era direcionada para uma linhagem específica, a de Ganelon, responsável pelo desastre de Roncesvales na Chanson de Roland. Mas se aqui a traição fora um crime individual, desde fim do século XII há um trabalho de readaptação no qual o fato de se pertencer a essa família já tornava o personagem passível de ser um traidor. As suas traições podiam ir da falsa acusação até ao envenenamento de outros personagens. A prova da traição se dava frequentemente através do duelo judicial e os culpados, além de condenados à morte, podiam ter os corpos destruídos para evitar a ressurreição no final dos tempos.

Palavras-chave: Traição, Monarquia, França Capetíngia, Canção de Gesta, Literatura Medieval. 


\begin{abstract}
ARIAS, Ademir A. M. Treason in the Songs of Geste and the Strengthening of Capetingian Monarchy: France, 1180-1328. 2015, 000 folhas. Tese (Doutorado) Faculdade de Filosofia, Letras e Ciências Humanas, Universidade de São Paulo, São Paulo, 2015 .
\end{abstract}

Treason is a theme that we have been studying for some time, using as sources the Songs of Geste, a poetic genre current in the regions that made up the France's kingdom, between the eleventh and the fifteenth centuries. That poetry's golden period coincided as the dynasty of government known as the "direct Capetian" which reign and father to son succession persisted without interruption from 987 to 1328.

Created and disseminated in the various France's territorial manorials, especially in the northern kingdom, the Songs of Geste treated in their plots of various problems of moral and political force at that time. In a society whose cohesion, at least in its ruling layer, was based on loyalty and creating vassalian ties, treason constituted a serious threat to stability and peace. Both Christian morality as the moral chivalry condemned those who practiced it, but that did not stop their constant occurrence.

We studied five epic poems: the Chanson de Roland (C1100), the Girart de Vienne (1180-1185), the Renaut de Montauban (early thirteenth century), the Gaydon (1230-1240) and Jehan de Lançon (half of the century XIII). Roland, is the oldest of those poems, has a respected monarch, and differs from the later poems whose plots value the characters known since the nineteenth century as "Vassals Rebels".

From the analysis of treason in this poetry and the relationship between vassals and the king, we could draw some important points. Initially the connected to the vocabulary question because traïson / traître / traïr designate one of the most serious crimes described there, thanks to its connection with the neo testamentary tradition of Jesus' delivery by Judas Iscariot, supplanting other terms Latin or not (proditio, felonie).

In Chansons, the treason is primarily directed against the barons and knights and the executors are of the same social condition of their victims. Only belatedly it calls an attack against the monarch. Another point is the defense, in the poems, from the right to the war to the lord if he does not achieve his justice's obligations to his vassal. Thus, the heroes in the fight against Charlemagne were not shown by the poet as traitors but as victims of persecution. Those knights keep respect for their master and aspire to be forgiven and reintegrated to the royal court.

Responsibility for treason is directed to a specific lineage, that of Ganelon, responsible for Roncesvales' disaster in the Chanson de Roland. But if here the treason was an individual crime, since the end of the twelfth century there is a readjustment work in which the fact of belonging to that family already makes the character capable of being a traitor. Their treasons can go from false accusation to the poisoning of other characters. The proof of treason is often done through the judicial duel and the guilty, beyond sentenced to death, they might have their bodies destroyed to prevent the resurrection at the end of time.

Keywords: Treason, Monarchy, Capetingian France, Song of Geste, Medieval Literature. 


\section{LISTA DE QUADROS}

Quadro nº $^{\circ}$ - Distribuição de Traïson / Traïtre / Traïr na Chanson de Roland . .71

Quadro n 02- Distribuição de Traïson / Traïtre / Trä̈r no poema Girart de Vienne . .73

Quadro no 03- Distribuição de Traïson / Traïtre / Traïr no poema Renaut de Montauban 74

Quadro n ${ }^{04}$ - Distribuição de Traïson / Traïtre / Trä̈r no poema Gaydon .78

Quadro ${ }^{\circ}$ 05- Distribuição de Trä̈son / Traïtre / Traïr no poema Jehan de Lançon ........79

Quadro n ${ }^{\circ}$ 06- Distribuição de Felonie / Felon - Fel na Chanson de Roland ......................82

Quadro ${ }^{\circ}$ 07- Distribuição de Felonie / Felon - Fel no poema Girart de Vienne ..............84

Quadro ${ }^{\circ}$ 08- Distribuição de Felonie / Felon - Fel no poema Renaut de Montauban .....85

Quadro n ${ }^{\circ}$ 09- Distribuição de Felonie / Felon - Fel no poema Gaydon .............................86

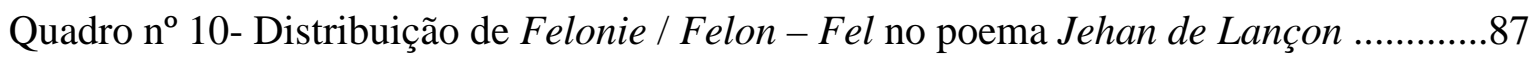




\section{SUMÁRIO}

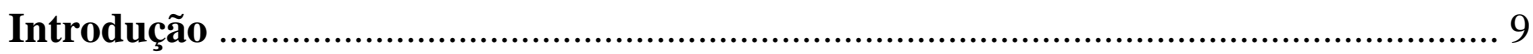

1- As Canções de Gesta, sua relação com a monarquia capetíngia e o problema

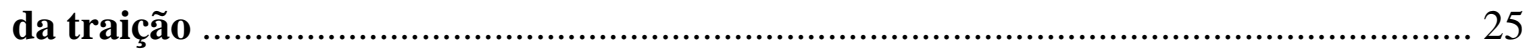

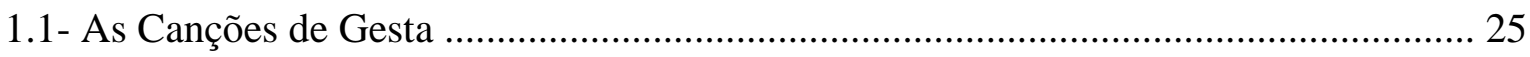

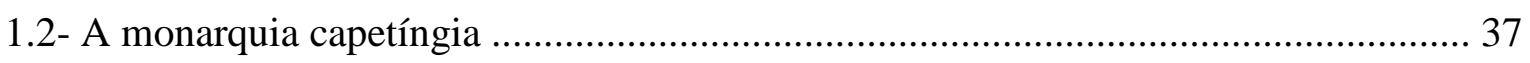

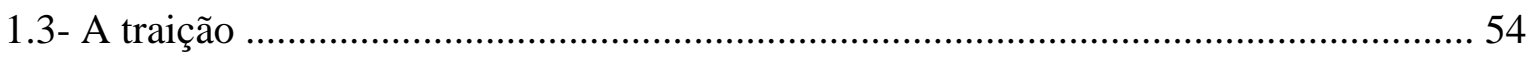

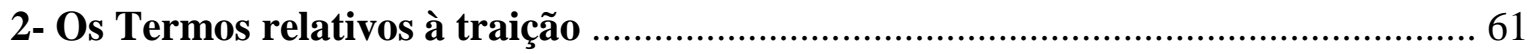

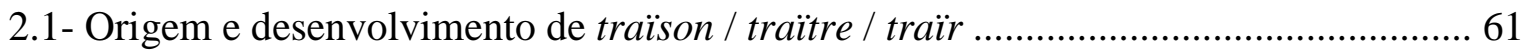

2.1.1- Tradere / traditio / traditor e os designativos latinos da traição ..............................61

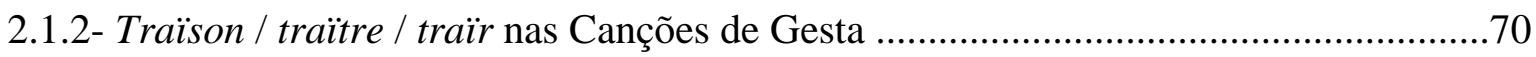

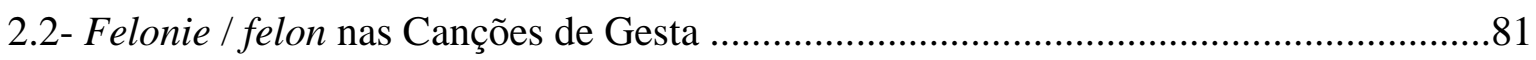

2.3- Termos raros, mas designativos da traição ................................................................ 88

2.4- Palavras que podem tomar o sentido de traição .........................................................92

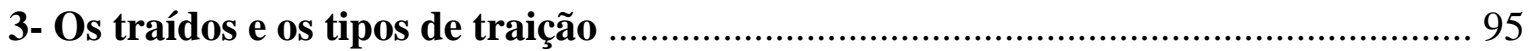

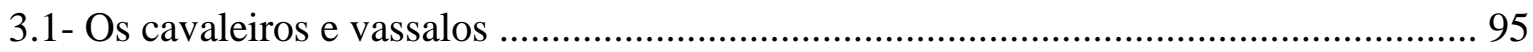

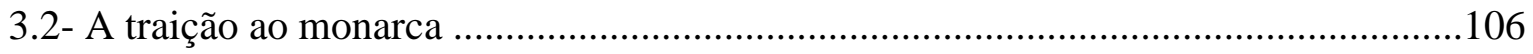

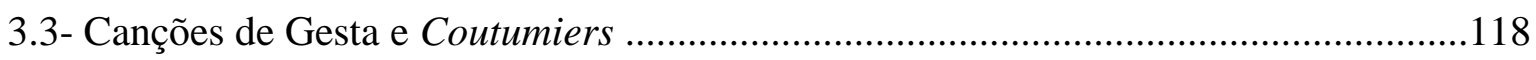

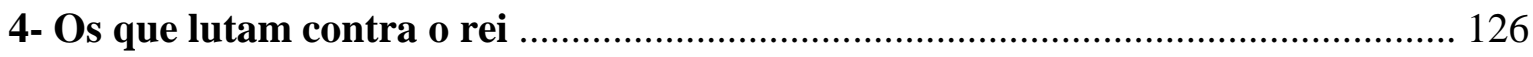

4.1- Entender quem são os vassalos em conflito com o rei .......................................... 126

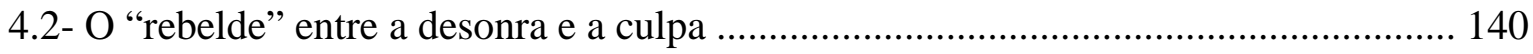

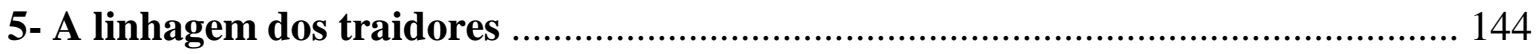

5.1- As transformações do personagem Ganelon e de sua linhagem .............................. 144

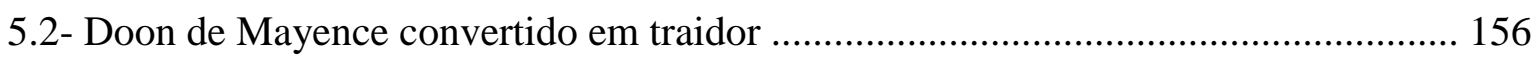

5.3- As dificuldades para descobrir, julgar e punir a traição .......................................... 157 
Conclusão 167

Bibliografia

Apêndices 182

Apêndice 1 - Resumo da Chanson de Roland 183

Apêncide 2 - Resumo do poema Girart de Vienne 187

Apêndice 3 - Resumo do poema Renaut de Montauban 190

Apêndice 4 - Resumo do poema Gaydon 196

Apêndice 5 - Resumo do poema Jehan de Lançon 199

Apêncice 6 - Mapa do império franco após o tratado de Verdun 202

Apêndice 7 - A França feudal (parte Norte e parte Sul) 203 


\section{INTRODUÇÃO}

A traição na Idade Média é um tema que nos prende a atenção já faz alguns anos, assim como o estudo das Canções de Gesta, um gênero literário épico próprio da sociedade aristocrático-cavaleiresca francesa, cuja circulação sob a forma poética deu-se do final do século XI até fins do século XV. Esse interesse levou-nos a elaborar e defender, em 2005, uma dissertação de mestrado na Universidade Estadual Paulista - UNESP, Campus de Assis, para a qual demos o título "A traição na canção de gesta Renaut de Montauban: herança neotestamentária, ética cavaleiresca e evolução política no reino da França no século XIII"1. A escolha da Canção que seria analisada naquele trabalho deu-se após a leitura de várias narrativas distintas e, graças a isso, tínhamos conhecimento do conteúdo de diversos poemas. Nessa época já pensávamos na possibilidade de ampliar nossas pesquisas através da comparação do conteúdo de alguns poemas e verificar como a traição aparecia em cada um deles, levando-se em conta que cada texto havia sido escrito em data diferente a dos demais. Havíamos notado durante o preparo da dissertação a ocorrência de variações quanto ao emprego dos termos designativos da traição e as situações assim identificadas nas diversas narrativas épicas então lidas. Naquele momento não aprofundamos o estudo comparativo, pois havíamos conscientemente limitado nossa empreitada a uma única fonte, a uma única Canção, ao poema Renaut de Montauban.

Retomamos agora esse projeto e observamos muitas mudanças em relação à época das nossas primeiras pesquisas. Embora várias obras no decorrer do século $\mathrm{XX}$ tenham dedicado capítulos ou páginas a essa questão, muitas vezes tentando estabelecer como a traição era vista entre os séculos V e XV, de 2005 em diante muitos estudiosos se voltaram para a análise ou reanálise da traição na Idade Média, tendo havido vários colóquios dedicados a esse tema. Uma das observações relativas à traição, escrita ainda no final do século XIX, e talvez a mais citada trabalhos posteriores, foi dada por F. Pollock e F. W. Maitland na obra The History of English Law before the Time of Edward I, era a de que

\footnotetext{
1 ARIAS, Ademir Aparecido de Moraes. A traição na canção de gesta Renaut de Montauban: herança neotestamentária, ética cavaleiresca e evolução política no reino da França no século XIII. 2005. Dissertação (Mestrado em História Social) - Faculdade de Ciências e Letras de Assis, Universidade Estadual Paulista UNESP. Assis, 2005.
} 
"Traição é um crime que tinha uma circunferência vaga e mais de um centro"2. Ou seja, ela teria sido encarada de uma forma muito maleável e qualquer ato poderia ser qualificado como traição. Isso acabou levando à criação, no reino da Inglaterra, de um "Estatuto das traições", em 1352, sob Eduardo III, no qual se tentava estabelecer o que deveria ser efetivamente tratado como traição ao rei e, desse modo, impedir o monarca de usar esse tipo de acusação para toda situação contrária aos seus interesses.

A Baixa Idade Média (séculos XIV-XV), sobretudo no contexto da Guerra dos Cem Anos e das lutas dos monarcas contra os grandes barões e príncipes territoriais na França (conflito entre Armagnacs e Borguinhões, 1407-1435) e na Inglaterra (Guerra das Duas Rosas, 1455-1485), atraiu pesquisadores interessados nos julgamentos dos casos de traição, tornados comuns nessa época. Esse também foi um período de crises no qual as monarquias europeias, para enfrentá-las, procuraram fortalecer seu poder e o de seus reinos em bases nacionais. J. G. Bellamy ${ }^{3}$ dirigiu seus estudos para a Inglaterra de Eduardo I (1272-1307) até Henrique VII (1485-1509), enquanto S.H. Cuttler ${ }^{4}$ dedicou-se à França dos últimos Capetos “diretos" (1285-1328) e da ascensão da dinastia dos Valois até Luís XI (1461-1483). Para os dois lados do Canal da Mancha, uma das transformações colocadas por esses autores foi a da condenação do levante armado contra o rei, procedimento este aceito enquanto vigorava o entendimento de que a relação entre o monarca e o seu subordinado era contratual, vassálica, e caso o "senhor" falhasse com seu "homem", ao não oferecer proteção ou justiça, este teria o direito de tomar armas contra seu superior.

Não encontramos obras específicas dedicadas ao estudo da traição ao rei ou aos grandes senhores territoriais na França capetíngia, do século XI ao XIII. Mas notamos ter havido um grande interesse por esse tema no caso de trabalhos de erudição sobre as Canções de Gesta, manifestado principalmente sob a forma de artigos e com predileção pela Chanson de Roland. Já em 1869, Léon Gautier havia escrito sobre os ideais políticos presentes na poesia épica e o caso do julgamento de Ganelon teve uma atenção especial, com o autor procurando mostrar que o procedimento legal usado no episódio era baseado

\footnotetext{
${ }^{2}$ POLLOCK, Frederick; MAITLAND, Frederic William. The History of English Law before the Time of Edward I. Cambridge: Cambridge University Press; Boston: Little, Brown, \& Company, Vol. II, 1898, p. 503.

3 BELlamY, J. G. The Law of Treason in England in the Later Middle Ages. Cambridge: Cambridge University Press, 2004.

4 CUTTLER, S. H. The Law of Treason and Treason Trials in Later Medieval France. Cambridge: Cambridge University Press, 1981.
} 
em antigas tradições germânicas ${ }^{5}$. Mais de um século depois, Emanuel J. Mickel ao escrever o livro Ganelon, Treason, and the "Chanson de Roland", reavaliou o crime cometido por Ganelon comparando os procedimentos judiciais descritos no poema com o direito consuetudinário que começava a ser colocado por escrito entre fins do século XII e no transcorrer do século XIII. Para este último autor as ações relacionadas ao julgamento, presentes no texto poético, são aquelas aceitas e correntes na Idade Média Central (séculos XI-XIII), não se tratando, portanto, de antigas tradições germânicas ou carolíngias conservadas sob a forma oral.

Outro artigo sobre traição e Canções de Gesta foi escrito por Adalbert Dessau ${ }^{7}$, em 1960, e embora fosse um texto curto apresentava uma série de apontamentos interessantes relativos à menção desse crime. O principal ponto defendido por esse autor era a ocorrência de uma mudança na visão da revolta contra o monarca, o que refletiria uma alteração nos conceitos sobre a quebra da fidelidade nos meios onde circulavam os poemas épicos, com o público se tornando desfavorável ao "rebelde", mesmo tendo este alguma justificativa para combater o seu senhor. Embora questionemos algumas colocações de Dessau ainda assim o consideramos essencial para qualquer trabalho versando sobre este tema.

Com relação a congressos voltados à traição na Idade Média, entre 24 e 26 de novembro de 1995, em Montpellier, já houvera um colóquio internacional com o tema Felonie, trahison, reniements au Moyen Age. Suas atas foram publicadas em $1997^{8}$ e tanto o encontro como a publicação demonstravam ser esse assunto algo extremamente amplo, pois nele estavam envolvidas a sensibilidade dos indivíduos e a tradição cultural cristã, cujas representações eram manifestadas principalmente através das diversas formas literárias correntes da época, fossem as Canções de Gesta, os Romances Arturianos ou as obras baseadas em histórias da Antiguidade. Observa-se nessa coletânea de artigos o uso da literatura, especialmente aquela voltada à cavalaria, como um tipo de fonte privilegiada para se extrair ensinamentos sobre os temas em foco naquele Colóquio.

\footnotetext{
${ }^{5}$ GAUTIER, Léon. L'Idée politique dans les chansons de geste. Revue des questions historiques, T-VII, 1869 , p. 79-114.

6 MICKEL, Emanuel J. Ganelon, Treason, and the "Chanson de Roland”. [S.1.]: Pennsylvania State University Press, 1989.

7 DESSAU, Adalbert. L'idée de la trahison au moyen âge et son rôle dans la motivation de quelques chansons de geste. Cahiers de civilisation médiévale, T-9, $\mathrm{n}^{\circ}$ 1, 1960, p. 23-26.

8 FÉLONIE, TRAHISON, RENIEMENTS AU MOYEN AGE. Actes du troisième colloque international de Montpellier, Université Paul-Valéry (24-26 novembre 1995). Montpellier: Cahiers du C.R.I.S.I.M.A., 1997.
} 
Em 2007 foram reunidos outros estudos voltados à representação da traição no imaginário das letras europeias e das culturas ocidentais. Sob o título Figures du traître ${ }^{9}$, vários autores analisaram diversos personagens ligados a eventos de traição e tanto Judas Iscariótes como Ganelon não foram esquecidos nessa obra. Apesar de ser uma coletânea abrangente cronologicamente, com artigos dedicados do século IV ao século $\mathrm{XX}$, o medievo se apresentava de um modo marcante na formulação e na fixação da figura do traidor como nós a conhecemos.

Também importante foi a ata de um colóquio realizado na Universidade de Lyon Jean Moulin, entre 11 e 13 de junho de 2008, e cujas comunicações foram reunidas sob o título La trahison au Moyen Age. De la monstruosité au crime politique (V-XV siècle $)^{10}$. Neste caso, houve uma diversificação maior das fontes e os artigos consistiram de estudos pontuais sobre diversos episódios nos quais a traição esteve presente, do período merovíngio até fins do século XV, em especial no reino da França e nos domínios Plantagenetas. Nestes trabalhos foram apresentados vários exemplos de como a traição poderia ser entendida e representada em textos oriundos de diversas regiões da Europa e em épocas distintas do medievo.

Uma iniciativa interessante foi colocada em prática pela Faculté des Lettres d'Orléans, França, onde o estudo literário e o estudo do direito, inseridos no programa La Lettre et le Droit, levaram à realização de jornadas onde eram apresentados artigos relacionados a crimes descritos nas mais diversas obras literárias medievais. Três destes trabalhos, onde a traição era tratada com frequência, e dirigidos principalmente por Bernard Ribemont, foram publicados com os títulos Crimes e chatiments dans la chanson de geste $^{11}$, referente à punição das faltas na epopeia, Le crime de l'ombre ${ }^{12}$, sobre o caráter oculto de alguns crimes, e La faute dans l'épopée médiévale ${ }^{13}$, sobre as incertezas quanto à condenação de alguns atos descritos em obras poéticas. Isso mostra o quanto a traição, como tema de pesquisa, é rico em oportunidades para os pesquisadores nela interessados. Em apoio a isso, as obras escritas deixadas pelo medievo, sejam elas literárias, crônicas,

\footnotetext{
${ }^{9}$ POLLET, Jean-Jacques; SYS, Jacques (Dir.). Figures du traître. Les représentations de la trahison dans l'imaginaire des lettres européennes et des cultures occidentales. Arras : Artois Presses Université, 2007.

10 BILLORÉ, Maïté; SORIA, Myiriam (Direction). La trahison au Moyen Age. De la monstruosité au crime politique (Ve-XVe siècle). Rennes : Presses Univesitaires de Rennes, 2009.

11 RIBÉMONT, Bernard (Dir.). Crimes et châtiments dans la chanson de geste. Paris: Klincksieck, 2008.

12 CRIME DE L'OMBRE (Le). Complots, conspirations et conjurations au Moyen Âge. Sous la direction de Corinne LEVELEUX-TEIXEIRA et Bernard RIBÉMONT. Paris : Klincksieck, 2010.

${ }^{13}$ RIBÉMONT, Bernard (Dir.). La faute dans l'épopée médiévale. Ambigüité du jugement. Rennes : Presses Universitaires de Rennes, 2012.
} 
anais, textos de leis ou costumes, são abundantes e férteis para quem deseje dedicar-se a essa questão.

Talvez o que mais interesse quem estuda a traição na Idade Média seja o fato dela ser citada e de modo recorrente nos textos, tanto os literários quanto as narrativas dos eventos ocorridos na época ou na legislação então usada. Essa recorrência pode indicar a preocupação com algo contrário a uma dupla característica da sociedade europeia medieval, baseada na fidelidade: a valorização da moral cristã e o enaltecimento de um ideal cavaleiresco ${ }^{14}$. O Cristianismo pregava a fidelidade a Deus, mas também entre os homens, entre inferiores e superiores, parentes, cônjuges, súditos e monarcas. Isto sedimentaria a união entre os seguidores de uma mesma religião e garantiria a harmonia daquela sociedade à espera da "segunda vinda do Cristo" e da fixação da Jerusalém celeste na terra. E o ideal cavaleiresco utilizava a representação de cavaleiros fiéis aos seus senhores, companheiros, parentes, incutindo nas mentes dos guerreiros uma conduta conforme a moral cristã e a honra da cavalaria ou da linhagem. O próprio "contrato" feudo-vassálico, ao regular as relações hierárquicas, jurídicas e de bens fundiários ou não, apresentava a fidelidade como condição de manutenção e perpetuação harmônica do sistema social vigente entre os séculos XI e XIII. Seu ritual envolvia o juramento do vassalo em ser fiel a um senhor e o toque em um objeto sagrado fazia da religião uma garantia do seu respeito, pois quem o violasse incorreria no pecado do perjúrio. O homem que prometia ser fiel assumia o compromisso de servir alguém tornado seu "senhor" através de seu apoio, principalmente militar, e por meio de seus conselhos na corte senhorial, deveres estes resumidos na expressão auxilium et consilium, "auxílio e conselho" ${ }^{\text {. }}$. Como quebrar a palavra dada era um perjúrio, quem fora infiel estaria condenando moralmente e a sua salvação após a morte seriamente comprometida. Entretanto, as fontes mais diversas mostram como essa idealização estava bem afastada da realidade. Jean Verdon observou ser o desejo de poder, a cobiça ou sentimentos opostos como amor e ódio os principais motivadores da traição, contrapondo-se a esse ideal de fidelidade cuja força moral era insuficiente para inibir a desejo de alguns indivíduos de obter algum tipo de sucesso a qualquer preço ${ }^{16}$.

\footnotetext{
${ }^{14}$ Empregaremos os adjetivos "cavaleiresco" e "cavaleiresca", embora não dicionarizados em português, em razão de outros estudiosos os utilizarem com frequência. Vide LE GOFF, J. \& SCHMITT, J.-Cl. Dicionário temático do Ocidente medieval. São Paulo: Imprensa Oficial; Bauru: EDUSC, 2002, p. 185, nota 1, do Prof. H. Franco Jr.

${ }^{15}$ GANSHOF, F.-L. Qu'est-ce que la féodalité ? Paris : Tallandier, 1982, p. 139-149.

${ }^{16}$ VERDON, Jean. Intrigues, complots et trahisons au Moyen Âge. Paris : Perrin, 2012, p. 13.
} 
Como material de estudo, pela sua difusão, pelo tempo em que permaneceu como uma forma poético-literária muito difundida nos meios da aristocracia cavaleiresca, pela forma como expressa os ideários morais e políticos da Idade Média Central nas regiões então integrantes do reino de França ou culturalmente ligadas a este, consideramos as Canções de Gesta uma excelente fonte para nossas pesquisas sobre a traição. Mas fomos obrigados a reconhecer duas limitações para o desenvolvimento de nosso trabalho com base nelas.

A primeira limitação foi a inviabilidade do estudo de todas as Canções de Gesta conhecidas, pois há uma quantidade razoável de poemas diferentes (cerca de uma centena), alguns deles com vários milhares ou mesmo dezenas de milhares de versos. Obrigatoriamente teríamos que reduzir nosso corpo de pesquisa, procurando ainda usar as fontes cujos temas, personagens e enredos tivessem algum tipo de ligação intertextual, possibilitando o relacionamento e o cruzamento de informações entre elas.

O segundo problema era a disponibilidade material das fontes, pois estaríamos presos à existência de textos editados e cuja aquisição fosse possível. Embora a Internet tenha disponibilizado muitas edições de poemas épicos, por exemplo, através dos sites da Biblioteca Nacional da França (Gallica), do Google Books e do Open Library, isso ocorreu numa época relativamente recente e boa parte dessas publicações, hoje tornadas de domínio público, surgiram no decorrer do século XIX ou início do XX e muitas já foram suplantadas por outras edições mais recentes.

Nossa escolha recaiu sobre cinco poemas escritos entre fins do século XI e metade do século XIII. Estes foram a Chanson de Roland (1060-1100), Girart de Vienne (11801184), Renaut de Montauban (início do século XIII), Gaydon (primeira metade do século XIII) e Jehan de Lançon (meados do século XIII). Optamos por essas Canções devido à relação existente entre estas, tendo como ponto de convergência a batalha de Roncesvales e a destruição dos pares da França, gerando uma forte dependência das quatro últimas Canções para com a Chanson de Roland. Girart de Vienne, Renaut de Montauban e Jehan de Lançon foram compostos para narrar eventos que teriam antecedido o desastre de Roncesvales, como o surgimento da amizade entre Rolando e Olivier e a possível origem da discórdia entre Ganelon e Rolando. Gaydon trataria de fatos posteriores a esse evento, como o destino dos envolvidos diretamente na punição ou na defesa do traidor dos doze pares da França. Portanto, verifica-se nesses poemas a presença contínua de diversos personagens em torno dos quais foram estruturadas as diversas histórias descritas nos 
textos: Carlos Magno, Rolando, Olivier, Ganelon e sua linhagem, Naimes da Baviera, Ogier o Dinamarquês, os doze pares da França.

Utilizamos a versão da Chanson de Roland existente no manuscrito de Oxford e escrito entre 1140 e $1170^{17}$. Acredita-se ser essa versão uma cópia em anglo-normando de um texto anterior, composto possivelmente em outro dialeto pouco depois de 1050. Embora existam outros seis manuscritos contendo esta narrativa ${ }^{18}$, muitos pesquisadores consideram o conteúdo do manuscrito de Oxford o exemplo mais acabado do gênero épico medieval francês, devido à sua estruturação e ao uso hábil dos recursos poéticos e narrativos pelo autor anônimo ${ }^{19}$. Ao contrário de outros poemas épicos, a Chanson de Roland não tem qualquer indicação de um título e nem diz claramente qual herói está sendo celebrado, mas desde a sua descoberta, na primeira metade do século XIX, a maioria dos estudiosos a considera como dedicada a Rolando, um pretenso sobrinho do imperador Carlos Magno. O poema do manuscrito de Oxford ainda é visto como um testemunho de como seriam as primeiras Canções de Gesta e, também, como a mais antiga narrativa épica francesa colocada por escrito até hoje encontrada. Todo o enredo desse poema gira em torno da traição perpetrada por um membro da hoste imperial levada à Espanha por Carlos Magno. Dessa traição resultara não apenas a destruição da retaguarda franca e a morte do braço direito do imperador, seu sobrinho Rolando, como também dá ensejo a um teste de força entre o poder real e o poder das linhagens, ameaçando o equilíbrio vassálico, defendido na narrativa, no qual o monarca detém uma superioridade moral diante dos grandes do reino.

Dada a sua antiguidade e o seu tema, a Chanson de Roland se presta a servir de parâmetro para a observação das mudanças que afetaram a poesia épica posterior. Isso decorre do fato dos outros poemas estudados aqui, pelo menos as versões usadas por nós e seguindo as análises de seus editores, terem sido desenvolvidas após 1180, enquanto o

${ }^{17}$ CHANSON DE ROLAND (La). Édition critique et traduction de Ian SHORT. Paris: Libr. Générale Française; Le Livre de Poche, 1990. CHANSON DE ROLAND (La). Édition critique par Cesare SEGRE. Genève: Droz, 2 tomes, 1989.

${ }^{18}$ Os seis manuscritos são: Veneza 4, da Biblioteca Marciana de Veneza, cujo texto é o mais próximo à versão do Manuscrito Oxford; Chateauroux, da Biblioteca Municipal desta cidade; Veneza 7, também da Biblioteca Marciana de Veneza; Paris, da Biblioteca Nacional da França; Cambridge, do Trinity College em Cambridge; e Lyon, da Biblioteca Municipal desta cidade. Há uma edição conjunta dos sete manuscritos, $L a$ Chanson de Roland / The Song of Roland. The French Corpus. General editor Joseph J. DUGGAN. Turnhout (Belgium): Brepols, 3 vols., 2005.

${ }^{19}$ Há um nome citado no verso 4002 da Chanson de Roland, "ci falt la geste que Turoldus declinet", mas não há a menor certeza de ser ele o autor do poema, podendo declinet significar apenas quem o transmitiu ou cantou. Vários pesquisadores tentaram identificar Turoldo, mas suas conclusões mostraram-se sempre questionáveis. BOISSONNADE, P. Du nouveau sur la Chanson de Roland. Paris: Ancienne Honoré Champion, 1923, p. 443-464. BURGER, André. Turold, poète de la fidélité. Genève: Droz, 1977, p. 99-107. LAFONT, Robert. La Geste de Roland. L'épopée de la frontière. Paris: L’Harmattan, T-I, 1991, p. 269-274. 
Roland do manuscrito Oxford conserva e transmite uma narrativa anterior ou corrente em 1100

Girart de Vienne, segundo seu editor Wolfgang Van Emden, é um dos poemas mais antigos com a temática da revolta vassálica, tendo sido composto no início do reinado de Felipe Augusto, entre 1181 e $1185^{20}$. Nesses primeiros anos de seu governo, Felipe enfrentou uma rebelião de diversos barões territoriais, entre os quais o conde da Champagne, terra de origem do remanejador da narrativa ${ }^{21}$, e o duque da Borgonha, região na qual vivera um Girart, conde de Vienne (819-877), durante o reinado dos carolíngios Luís o Piedoso e Carlos o Calvo ${ }^{22}$. A versão hoje conhecida na íntegra é obra de Bertrand de Bar-sur-Aube e este deixou claro no próprio texto de seu poema que estava remanejando, ou seja, efetuando alterações em uma narrativa antiga e conhecida, ao incluir-lhe um início e um final ambos desconhecidos de outros poetas e jograis ${ }^{23}$. Existem resumos de uma versão primitiva desta Canção em duas obras do século XIII, na Karlamagnus Saga (c. 1250), tradução norueguesa de uma coletânea de poemas épicos

\footnotetext{
${ }^{20}$ BERTRAND DE BAR-SUR-AUBE. Girart de Vienne, publié par Wolfgang VAN EMDEN. Paris: A. e J. Picard, 1977.

${ }^{21}$ Os estudiosos das Canções de Gesta concordam em que não exise nenhum texto conhecido o qual possa ser considerado como o "original" ou o primeiro escrito de um poema. Todos os manuscritos existentes são considerados "remanejamentos", ou seja, narrativas antigas adaptadas por poetas dos séculos XII e XIII em conformidade com as realidades e os gostos de seu tempo. As Canções primitivas sofreram inclusões de episódios, de personagens e de motivos literários desconhecidos dos poemas quando eles surgiram.

${ }^{22}$ LOUIS, René. De la légende à la histoire: Girart, comte de Vienne (...819-877) et ses fondations monastiques. Auxerre: Aux Bureaux de l'Imprimerie Moderne, 1947.

${ }^{23}$ Bertrand de Bar-sur-Aube afirma, no início de seu poema, nos versos 81-89:
}

Del duc Girart avez sovant oi, cil de Vianne au coraje hardi, et d'Emenjart, et del conte Aimeri ; mes del millor vos ont mis en obli cil chanteor que vos en ont servi, car il ne sevent l'estoire que ge di: la començaille dont la chançon oisi, qui fu Girart ne ses peres ausin; mes geu dirai, que bien le sai de fi.(grifos nossos).

E nos versos 6564-6569, o poeta fala sobre o final da narrativa, após a captura de Carlos por Girart:

Ceste chançon n'est pas par tot seüe.

Tel vos en chante que n'a pas retenue la droite estoire c'avez ci entandue, si com Charlon a la barbe chenue fu pris chacent en la serve ramue, qant l'en mena en sa cité cremue li dus Girart come oisel pris en mue.

São informações claras, do próprio Bertrand, de que ele estava incluindo elementos novos da história de Girart de Vienne, mas tomando o cuidado de negar serem criações suas e sim a retomada de episódios desconhecidos dos demais poetas e jograis. 
franceses ${ }^{24}$, alguns deles sem textos conhecidos em francês, e a Chronique Rimée de Felipe Mousket $(1242)^{25}$, narrativa histórico-poética das origens troianas dos franceses até o reinado de Felipe Augusto. Estes resumos mostram um Girart, senhor de Vienne ${ }^{26}$, desafiador e não cumpridor de seus deveres vassálicos, obrigando Carlos Magno a sitiar a cidade desse barão. No decorrer da luta surge a amizade entre Rolando, sobrinho do imperador, e Olivier, sobrinho de Girart, o que situava este poema como narrativa dos eventos anteriores à expedição contra os sarracenos espanhóis e Roncesvales.

Bertrand altera essa antiga Canção, na qual a responsabilidade pela guerra era lançada sobre um vassalo originalmente desobediente, ao eximir este da culpa pelo início e continuidade da guerra. Para o poeta, Girart teria sido um modelo de fidelidade como cavaleiro e barão desde sua infância e o conflito somente ocorrera devido aos erros de Carlos Magno, incapaz de fazer justiça ao seu homem após este ter sido ultrajado pela rainha. Por ser um dos poemas no qual um vassalo fiel aparece em luta contra seu senhor devido a uma injustiça deste, por ter esse tema se tornado corrente no final do século XII e durante todo o século XIII, e por ser essa alteração mostrada claramente tanto pelas palavras do poeta como pela existência de testemunhos lendários anteriores, nos quais havia uma história muito diferente, incluímos o Girart de Vienne entre os poemas deste estudo. Para nós ele marca o rompimento de uma tradição favorável ao monarca, substituída por outra elogiosa dos vassalos em luta contra o rei. Existem cinco manuscritos desse poema e o editor Wolfgang Van Emden preferiu utilizar como base de sua publicação o manuscrito que leva a codificação G, o qual pertence ao acervo do Museu Britânico em Londres, e cuja escrita foi estimada pelos estudiosos como do final do século XIII. Este é também considerado o texto mais completo e próximo ao original, de autoria de Bertrand, no final do século XII.

O poema Renaut de Montauban foi a fonte usada para o desenvolvimento de nossa dissertação de mestrado ${ }^{27}$. Essa narrativa, descrevendo as lutas de um grupo de cavaleiros contra Carlos Magno, as diversas traições ali orquestradas, nas quais a linhagem de

\footnotetext{
${ }^{24}$ SAGA DE CHARLEMAGNE (La). Traduction, notices, notes et index par Daniel W. LACROIX. Paris: Le Livre de Poche, 2000.

${ }^{25}$ PHILIPPE MOUSKES. Chronique rimée. Publiée par le Baron de Reinffenberg. Bruxelles : M. Hayez, TI, 1836 ; T-II, 1838.

${ }^{26}$ A cidade nomeada nesta Canção de Gesta está localizada às margens do rio Ródano, no atual departamento francês de Isère. Embora o nome latino corrente no tempo do império Romano fosse Viena, preferimos manter o nome "Vienne" no corpo do nosso trabalho para evitar qualquer confusão com a cidade de Viena (Wien, em alemão), localizada às margens do Danúbio e capital da Áustria.

${ }^{27}$ RENAUT DE MONTAUBAN. Édition critique du manuscrit Douce par Jacques THOMAS. Genève: Droz, 1989.
} 
Ganelon tem papel de destaque, onde se chocam as questões da fidelidade ao monarca, da moral feudal e das obrigações dentro das linhagens, tornaram esta Canção extremamente rica e fundamental para a análise comparativa com outras obras épicas. Foi dela que extraímos os dados básicos de nosso estudo e empregamos as informações obtidas durante Mestrado para direcionar as pesquisas nos demais textos. Há ainda uma característica especial em relação aos poemas Gaydon e Jehan de Lançon, pois possivelmente os poetas que criaram estas duas últimas narrativas aproveitaram-se de certos elementos existentes na história do Renaut de Montauban, entre eles o caráter traiçoeiro dos Ganelidas ${ }^{28}$.

Utilizamos a edição estabelecida por Jacques Thomas, utilizando o manuscrito Douce ou “D”, pertencente à Biblioteca Bodleian de Oxford, que apesar da perda de alguns fólios, ainda assim apresenta características condizentes com a versão original do poema, tendo sofrido poucos remanejamentos ou amplificações. Tivemos à nossa disposição outra versão da história dos Aymonidas, existente no manuscrito denominado La Valière ${ }^{29}$, da Biblioteca Nacional da França, e cuja edição original é de 1909. Mas quando comparamos as duas publicações e observamos o conteúdo os dois textos, este último apresenta inclusões de episódios e outros detalhes a diferenciá-lo do manuscrito Douce e afastando-o do poema primitivo ou arquétipo ${ }^{30}$.

Verificamos nessas duas versões do Renaut de Montauban a menção, especialmente nos diálogos entre os diversos personagens, de determinadas aventuras inexistentes nas narrativas contidas nesses manuscritos. O caso mais emblemático é a citação de ter ocorrido, no mesmo momento da morte de Bertolai, a morte de Luís, filho de Carlos Magno, mas pelas mãos de Ricardinho (Richardet, Richardin), o irmão mais novo de Reinaldo. O episódio descrito dessa forma não existe no manuscrito Douce e nem no manuscrito La Valière. Parece ter sido muito amplo o lendário sobre os quatro filhos de Aymon, de modo que os jograis e poetas podiam criar narrativas diversificadas incluindo ou excluindo determinadas aventuras dos irmãos cavaleiros. A eliminação desta "façanha"

\footnotetext{
28 Empregamos a expressão «Ganelidas » para nomear a parentela de Ganelon como um todo. É uso corrente nos estudos sobre as Canções de Gesta identificar uma linhagem com algum personagem de destaque ou fundador de seu poderio e riqueza. Assim, a linhagem de Guilherme de Orange é chamada de "Aymerida", homenageando ao pai do herói, Aymeri de Narbonne. Já os "Aymonidas", no poema Renaut de Montauban, são os filhos de Aymon de Dordonne.

${ }^{29}$ CHANSON DES QUATRE FILS AYMON (La). D'après le manuscrit La Vallière, par Ferdinand CASTETS. Genève: Slatkine, 1974. Trata-se de um reprint da edição de Montpellier, 1909.

${ }^{30}$ PAGANO, Mario. Encore quelques rotules sur les versions D e L du Renaut de Montauban. In : ENTRE ÉPOPÉE ET LÉGENDE: Les quatre fils Aymon ou Renaut de Montauban. Études publiées sous la direction de Danielle QUÉRUEL. Langres - Saint-Geosmes: Dominique Guéniot, Vol. I, 2000, p. 169-181.
} 
em particular impedia a repetição do crime cometido por Bueves de Aygremont, tio dos Aymonidas, e assassino de Lotário, outro filho do imperador. A história de Bueves teve como desfecho a sua morte e a derrota de sua linhagem em combate frente a Carlos, pois não haveria como se obter o perdão quando se matava um filho do monarca. Essa exclusão dá a entender que paz de Reinaldo com o imperador ficaria comprometida se fosse preservado no poema o episódio da morte de Luís.

Editado em 1862, a Canção nomeada Gaydon ${ }^{31}$ não conheceu edições recentes, embora tenha servido de base a um exaustivo estudo por Jean Subrenat ${ }^{32}$. O texto é desenvolvido como uma continuação da Chanson de Roland e mostra as atribulações sofridas por Thierry, o cavaleiro vencedor de Pinabel e responsável por provar a traição de Ganelon. O desastre de Roncesvales e a punição do traidor servem de incentivo à criação desse poema, que não apresenta qualquer elemento histórico discernível em seu enredo. Para Subrenat, esta Canção, escrita na primeira metade do século XIII, talvez entre 1230 e $1234^{33}$, teria surgido para estimular os barões e cavaleiros do Condado de Anjou à aceitação do domínio da monarquia capetíngia, vitoriosa na luta contra o Plantageneta João sem Terra após 1202 e, principalmente, após as fracassadas tentativas de Henrique III, entre 1228 e 1235 , de reaver pelas armas os antigos territórios de sua linhagem ${ }^{34}$. No poema, Thierry, conde de Angers, apesar de injustiçado por Carlos Magno, nunca nega sua condição de vassalo do imperador e nunca dirige ações prejudiciais ao seu senhor. Nos momentos nos quais o discurso do jovem barão toma uma linha mais agressiva, os seus servidores mais velhos dissuadem-no de ações prejudiciais à relação vassálica. Se há guerra, ela decorre dos erros de julgamento do monarca e não de iniciativas hostis do herói. O conflito é incentivado pela linhagem de Ganelon, convertida em fonte de todos os males do reino, mostrada como ambiciosa e infiel ao rei, a quem pretende assassinar. No texto, os Ganelidas chegam a ser demonizados, pois juram sua fé aos demônios e é por estes que as almas de seus mortos são arrebatadas, abrindo a possibilidade de o poeta trabalhar de forma cômica determinadas situações por ele descritas. O manuscrito usado na edição de F. Guessard e L. Luce é o catalogado com o número 860 do fundo francês da Biblioteca Nacional da França.

\footnotetext{
${ }^{31}$ GAYDON, chanson de geste. Publiée pour la première fois d'après les trois manuscrits de Paris, par F. GUESSARD et S. LUCE. Paris: A. Franck, 1862.

${ }^{32}$ SUBRENAT, Jean. Étude sur Gaydon, chanson de geste du XIIIe siècle. Aix-en-Provence: Presses Universitaires de Provence, 1974.

${ }^{33}$ Ibid., p. 29.

${ }^{34}$ Ibid., p. 50-51.
} 
A edição da Canção de Gesta Jehan de Lançon $^{35}$ apresentou vários problemas para nós, pois o único manuscrito completo é do século XV e apresenta-se muito remanejado, inclusive em relação à língua, muito distinta daquela corrente no século XIII, quando o poema original foi escrito. O editor, Jean Duplessy preferiu usar o manuscrito A, Paris, Biblioteca Nacional da França, fundo francês 2495, da segunda metade do século XIII, apesar de mutilado de boa parte do começo da narrativa. Utilizou o manuscrito Paris, Arsenal 3145, do século XV, apenas para suprir a ausência da parte inicial do poema (designação dos doze pares como embaixadores, chegada destes a Lançon, desencadeamento dos combates), mas na condição de apêndice, e assim permitir aos leitores terem uma ideia de como o poema teria sido na integra. Tal escolha se deveu às possíveis diferenças entre os dois textos tornando impraticável uma edição crítica na qual o mais recente deles supriria as carências do mais antigo. Esta Canção é uma narrativa sem fundo histórico. Jehan de Lançon $^{36}$ utilizou elementos e ideias já presentes em poemas épicos anteriores e representou uma alteração no ideário aristocrático-cavaleiresco, pois contrariava o favorecimento dos chamados "Vassalos Rebeldes", motivo este presente em quase todas as Canções de Gesta após 1180. No poema Jehan de Lançon, por mais intransigente e autoritário que Carlos Magno fosse, ele não era criticado por querer impor sua vontade a um barão e submetê-lo ao seu poder. Para justificar sua vitória final, o seu opositor foi caracterizado como alguém originário da linhagem de Ganelon e esta não apenas opõe-se aos interesses do rei, como ainda ambiciona destroná-lo em favor de algum de seus membros. Isso permitia ao poeta criar seu personagem com caráter negativo e assim lançar sobre ele a culpa pelo conflito, além de condenar os seus procedimentos ardilosos contra os doze pares da França e o rei.

Estas são as cinco fontes principais em nosso estudo. Entretanto, diversas outras estão sendo utilizadas como apoio, para subsidiar o desenvolvimento da pesquisa e complementar os dados ou informações extraídos desses poemas. Por exemplo, quando falamos da questão da mudança no repertório das Canções de Gesta a partir de 1180, comparamos o Girart de Vienne de Bertrand de Bar-sur-Aube com os resumos dessa história na Karlamagnus Saga e na Chronique Rimée de Felipe Mousket, pois estas testemunham um estágio anterior do poema. Da Saga temos para estudo uma tradução no

\footnotetext{
${ }^{35}$ JEHAN DE LANÇON. Chanson de geste du XIIIe siècle. Publiée par Jean DUPLESSY. Paris: Le Léopard d'Or, 2004.

${ }^{36}$ Encontramos, durante nossas pesquisas, duas grafias para este poema e para o personagem que o nomeia. Ele é escrito como "Jehan de Lançon" pelo seu editor, J. Duplessy, e como "Jean de Lanson" em artigos consultados, como os de autoria de Dominique Boutet. Adotamos em nosso texto a grafia Jehan de Lançon, uma vez que é aquela utilizada por quem publicou a Canção.
} 
francês moderno, mas a existência desse texto, com a narrativa que nos interessa, basta para os nossos objetivos, pois disponibiliza esse episódio para cotejar com a história criada por Bertrand. Da Chronique obtivemos uma edição antiga, da primeira metade do século XIX, mas ela traz o poema completo, com seus 31.286 versos $^{37}$. O episódio da revolta de Girart corresponde aos versos 4.496 e 4.547.

Do mesmo modo, para tratarmos das transformações verificadas no personagem Ganelon e na sua linhagem, recorremos a outros poemas épicos como o Fierabras $^{38}$ e o Gui de Bourgogne $e^{39}$. Através da comparação entre estes textos e destes com as fontes principais fica mais claro que somente na passagem do século XII para o XIII foi sendo fixada a imagem da má linhagem, degenerada e geradora de traidores. Com isso Ganelon deixou de ser o responsável único pelo desastre de Roncesvales e foi reduzido a apenas um membro, embora exemplar, de uma família dominada pelos vícios, na qual a propensão para trair estava no sangue.

Apesar de afastados da literatura cavaleiresca, empregamos em conjunto com estas alguns "Costumes" (ou Coutumiers) compilados no século XIII em diferentes regiões do reino da França. Assim pudemos relacionar o conteúdo das Canções de Gesta referentes à traição e à infidelidade com testemunhos do pensamento jurídico corrente nesse período. Emanuel Mickel usou esse procedimento e demonstrou ser ele muito útil, pois se percebe como a poesia épica francesa estava imbricada com as ideias e conceitos, inclusive legais, vigentes na época em que foi escrita, distanciando-se do passado carolíngio cuja compreensão já se havia perdido. Esse estudioso coloca as Canções de Gesta como frutos de uma sociedade onde predomina a oralidade, apresentam suas histórias em um presente visto como eterno e igual aos tempos pretéritos e sejam próprias ao período de reorganização feudo-vassálica em favor dos grandes senhores territoriais e do rei francês. Valores e leis são percebidos como se fossem aqueles dos ancestrais embora, na realidade, divirjam destes ${ }^{40}$.

\footnotetext{
${ }^{37}$ Embora a Chronique de Mousket conste em um dos volumes da Monumenta Germaniae Historica, tratase de uma edição parcial e justamente os versos referentes à revolta de Girart de Vienne foram descartados pelo editor, Ad. Tobler. MONUMENTA GERMANIAE HISTORICA. Scriptorum. Tomus XXVI. Leipzig : Verlag Karl W. Hiersemann, 1925, p. 718-821.

${ }^{38}$ FIERABRAS. Chanson de geste du XIIe siècle. Éditée par Marc LE PERSON. Paris: Champion, 2003.

${ }^{39}$ GUI DE BOURGOGNE, chanson de geste. Publiée pour la première fois d'après les manuscrits de Tours et de Londres par MM. F. GUESSARD et H. MICHELANT. Paris : Vieweg, 1859.

${ }^{40}$ MICKEL, Emanuel J. Op. cit., p. 21.
} 
Temos disponíveis para nosso estudo os Coutumes du Beauvaisis, de Felipe de Beaumanoir $^{41}$, escrito em 1283, os Etablissements de Saint Louis ${ }^{42}$, datados de 1272 e originário da região de Orléans e o Coutumiers de Normandie ${ }^{43}$, parte escrita no final do século XII (Summa de legibus Normannie) e parte na metade do século XIII (Grand Coutumier de Normandie). Esses "Costumes", mesmo quando seus autores eram oficiais reais ou senhoriais, permaneciam como obras de caráter privado e tinham por objetivo orientar aqueles que julgavam as ações legais levadas à sua presença, mas sem adquirir uma força coercitiva para a sua aplicação, embora como no caso dos Coutumiers de Normandie, podessem até adquirir uma autoridade quase oficial ${ }^{44}$. Embora existam muitos outros textos legais do século XIII as dificuldades para acesso aos mesmos limitou nossa pesquisa aos citados acima.

Nossa tese está dividida em cinco capítulos. No primeiro procuramos esclarecer o que são as Canções de Gesta, suas características, quando circularam, qual o seu público, as principais teorias sobre suas origens, as reformulações sofridas por elas enquanto circulavam e o paralelo existente entre as transformações que afetaram esse gênero literário e o aumento do poder monárquico na França, a partir de fins do século XII. Também tratamos neste capítulo da dinastia Capetíngia, resumindo sua ascensão ao trono francês, em 987, as dificuldades iniciais dos monarcas para impor-se perante os grandes senhores seus vassalos, em especial a dinastia angevina dos Plantagenetas, e o aumento paulatino de seu poder e riqueza. Demos uma atenção especial ao reinado de Felipe Augusto, quando os grandes barões territoriais são derrotados ou controlados, assim como aos avanços promovidos pelos sucessores deste monarca até a substituição dos chamados "Capetos diretos" pelo ramo dos Valois ${ }^{45}$. Por fim, aproveitamos para fazer um resumo sobre o que se sabe sobre a traição antes de 1180, as divergências quanto a sua definição, o que poderia

${ }^{41}$ PHILIPPE DE BEAUMANOIR. Coutumes de Beauvaisis. Texte critique publié par Am. SALMON. Paris: T-I, Alphonse Picard et Fils, 1899; T-II, A. et J. Picard, 1970.

${ }^{42}$ ÉTABLISSEMENTS DE SAINT LOUIS (Les). Publiées par Paul VIOLET. Paris : Renouard, Tome I, 1881 ; Tomes II et IV, 1886.

${ }^{43}$ COUTUMIERS DE NORMANDIE. Tome I: Le très ancien coutumier de Normandie, texte latin, publié par Ernest-Joseph TARDIF. Rouen : Espérance Cagniard, 1881. COUTUMIERS DE NORMANDIE. Tome I: Le très ancien coutumier de Normandie, textes français et normand, publiés par Ernest-Joseph TARDIF. Rouen : A. Lestrigant; Paris : A. Picard et Fils, 1903. COUTUMIERS DE NORMANDIE. Tome II: La Summa de legibus Normannie in cúria laicali. Textes critiques publiés par Ernest-Joseph TARDIF. Rouen: A. Lestringant ; Paris : A. Picard et Fils, 1896.

${ }_{44}^{44}$ THIREAU, Jean-Louis. Introduction historique au droit. Paris: Flammarion, 2e. édition, 2003, p. 132-134.

45 São conhecidos como "Capetos diretos" os monarcas franceses de Hugo Capeto (+996) até Carlos IV o Belo (+1328), que se sucederam no trono francês de pai para filho, ininterruptamente. A dinastia dos Valois constituía um ramo da linhagem Capetíngia. Felipe VI, o inaugurador da nova dinastia, era sobrinho do rei Felipe o Belo (1285-1314) e foi coroado devido ao falecimento de seus primos sem terem estes deixado um herdeiro do sexo masculino. 
ser entendido como traição na Roma republicana e imperial e entre os grupos germânicos do século V, o possível amálgama de tradições romanas, germânicas e cristãs (através dos Evangelhos) na formação do seu conceito no Ocidente Europeu e depois firmado no transcorrer da Idade Média Central.

Estudamos no segundo capítulo o vocabulário da traição. No caso, os termos traïson / traïtre / trair presentes nas Canções de Gesta e derivados dos termos latinos traditio / traditor / tradere e a ligação deles com a traição de Judas na Vulgata. Quantificamos as ocorrências nos poemas estudados e especificamos as situações onde essas palavras aparecem, mostrando como o seu emprego era direcionado a determinados episódios ou personagens dos poemas e a possível ampliação das situações reconhecidas com essa denominação. Procedemos do mesmo modo com felonie / felon, mas vemos, neste caso, uma descaracterização desses termos como designativos da traição ou mesmo da infidelidade e tentamos esclarecer essa situação. Há outros vocábulos possíveis de designar o crime aqui estudado, embora seu uso seja menos constante, e procuramos relacionar pelo menos aqueles cuja ocorrência aparente uma carga emotiva maior para o poeta e para seu público (p.ex. vendre, boisier). Poderia ocorrer de nomes próprios, como o de Judas Iscariótis, serem vistos como sinônimos de traição e esse é outro ponto analisado nesta parte da Tese.

O capítulo terceiro está voltado aos personagens dos poemas que são vítimas da traição, em primeiro lugar os cavaleiros e barões. Levando-se em consideração o conteúdo das narrativas, no início, tratava-se de um ataque individual e pessoal decorrente de inimizades surgidas na corte ou na hoste franca (Roland, Girart de Vienne). Só posteriormente o monarca é visto como vítima de traição (Gaydon, Jehan de Lançon), mas variando o entendimento de qual ação efetivamente poderia ser vista como tal e quais os personagens capazes de realizá-la (Renaut de Montauban). O estudo das situações onde os personagens são traídos mostra as formas como ela se dava e, ainda, como agiam os traidores, os motivos pelos quais alguns são escolhidos como vítimas dela e outros como seus realizadores.

No quarto capítulo estudamos os personagens designados como "rebeldes", os heróis das Canções Girart de Vienne, Renaut de Montauban e Gaydon, primeiro mostrando a impropriedade da expressão "vassalos rebeldes", dado o seu caráter negativo nas mentalidades cristãs medievais, pois o primeiro rebelde teria sido Lúcifer, com quem os personagens principais das narrativas não poderiam ser comparados. Observamos uma importante alteração na visão expressa pelas Canções de Gesta em relação aos vassalos em 
luta contra o rei, que de condenados em poemas primitivos, passaram a ser vistos com simpatia quando a monarquia capetíngia ameaçou a independência dos grandes senhores territoriais e patrocinadores dos poetas / jograis, de 1180 em diante. É também interessante observar a existência para o "rebelde" épico da possibilidade do perdão régio e da sua reintegração na corte de Carlos Magno, algo negado a quem fosse culpado de traição.

Quanto à origem do conflito entre senhor e vassalo e a sua resolução, estas podem estar associadas a um choque entre uma cultura de vergonha ou de desonra, fruto de uma antiga tradição greco-romana e germânica, com uma cultura de culpa ou de pecado surgida com o Cristianismo, confronto este intrínseco aos poemas épicos. A luta teria início devido a algum personagem se sentir desonrado e obrigado a tirar satisfação de uma afronta através de ações violentas; o final do conflito dar-se-ia quando este personagem, tomado pelo sentimento de culpa, buscasse o perdão do monarca, representante de Deus na terra.

A linhagem traidora é objeto do quinto capítulo e, neste caso, vimos como o personagem Ganelon e sua linhagem sofreram transformações desde a Chanson de Roland até o poema Jehan de Lançon, fazendo uma falta individual, decorrente da iniciativa de um único personagem, tornar-se uma mácula presente em toda uma família de grandes barões franceses. Outro ponto, as Canções de Gesta mostram a traição como algo feito às escondidas e, com isto, torna-se importante "provar" na narrativa a sua ocorrência embora o poeta e seu público saibam antecipadamente de sua existência e quem a perpetrou - e desmascarar o responsável por ela, algo que o enredo dos poemas não torna fácil, como se percebe facilmente no julgamento de Ganelon. Uma vez "provado" o crime, os traidores deveriam ser punidos e aqui não entra apenas a forma cruel das execuções, mas também definir quem seriam os executados, pois toda a linhagem podia estar envolvida nele. A traição como ato semelhante ao de Judas Iscariótis, inclusive devido à terminologia empregada, devia atingir os corpos dos faltosos de forma brutal e isto envolveria até a sua destruição física, talvez um ideal movido pelas crenças na ressurreição da carne no final dos tempos, conforme pregado pela religião cristã e na condenação eterna dos pecadores ao inferno.

A traição como objeto de estudo oferece um leque muito amplo para pesquisa, particularmente para a Idade Média. Além das Canções de Gesta outras fontes legadas pelos séculos $\mathrm{V}$ ao $\mathrm{XV}$ podem trazer elementos importantes para essa pesquisa. Com nosso trabalho esperamos incentivar outros estudiosos a explorar esse tema em outros escritos e em obras de arte deixados pelo medievo. 


\section{1- AS CANÇÕES DE GESTA, SUA RELAÇÃO COM A MONARQUIA CAPETÍNCIA E A PROBLEMÁTICA DA TRAIÇÃO}

Antes de passarmos à análise das nossas fontes e do tema proposto neste estudo, consideramos necessário apresentar um resumo dos três pontos nos quais apoiamos nossa tese: as Canções de Gesta, a realeza capetíngia e a traição. Pretendemos com isso demonstrar a relação existente entre esses pontos para justificar as nossas escolhas e a forma como desenvolvemos nosso trabalho. A poesia épica francesa, se observarmos cronologicamente, tomou forma quando a linhagem de Hugo Capeto substituiu a dinastia carolíngia, em fins do século $\mathrm{X}$, como governante do reino ocidental surgido com a partilha de Verdun (843). Esses poemas épicos e a linhagem capetíngia coexistiram até o desaparecimento do ramo principal desta última, em 1328. Quanto às Canções de Gesta, estas pararam de ser escritas enquanto forma poética na metade do século $\mathrm{XV}$, mas algumas de suas histórias, como a dos quatro filhos de Aymon, sobreviveram em textos em prosa até o começo do século XIX. No mesmo período de existência das Canções e dos Capetíngios, a vassalidade, juntamente com os juramentos de fidelidade, era usada para estabelecer relações hierárquicas dentro do reino da França e, desta forma, manter algum princípio de respeito da parte dos grandes senhores territoriais para com o rei. O rompimento dessas relações e as acusações de infidelidade e traição permeiam muitos textos épicos, levantando questões de grande interesse para o seu público aristocrático.

\section{1- As Canções de Gesta}

Receberam o nome de Canções de Gesta os cerca de cem poemas conhecidos, cujas características particulares os identificavam como um grupo diferenciado frente às outras formas literárias em língua vernácula surgidas nas regiões que constituíam o reino da França, na Idade Média Central. Escritos entre os séculos XI e XV, essas narrativas tratam de atos heroicos e guerreiros, sendo consideradas como o gênero épico francês medieval. A palavra latina Gesta era um neutro plural e pode ser traduzida por "coisas ou ações realizadas" e referia-se principalmente aos feitos heroicos dos antepassados ${ }^{46}$. Passou para

\footnotetext{
${ }^{46}$ SUARD, François. La chanson de geste. Paris: PUF, 1993. Guide de la chanson de geste et de sa postérité littéraire (XIe-XVe siècle). Paris: Honoré Champion, 2011. Estas duas obras de F. Suard são as
} 
a língua românica como uma palavra singular não só mantendo o significado de "façanhas" como também os significados de "Ciclo" (Gesta de Garin de Monglane, ou seja, Ciclo de Garin de Monglane) ou de linhagem (Gesta de Narbonne, entendida como feitos da linhagem narbonesa).

Épicas, as Canções de Gesta dão atenção às atividades guerreiras e àqueles que as executam e, com isso, há dois grupos de poemas correspondentes a dois períodos distintos nos quais os combatentes cristãos estiveram muito ativos. O primeiro deles está voltado para um passado quase mítico, o do reinado da dinastia carolíngia (716-987) e dos francos ancestrais dos franceses. As realizações de Carlos Magno (742-814), rei dos francos a partir de 768, fascinaram os governantes dos reinos surgidos com a fragmentação do império Carolíngio. Carlos extendeu seus domínios conquistando o reino lombardo do norte da península Itálica, submeteu e impôs o Cristianismo às tribos saxãs do norte da Europa, avançou as suas fronteiras para além dos Pirineus, derrotou os pagãos avaros. No ano 800, graças às suas vitórias, ao poder e ao prestígio acumulados, ele foi coroado imperador dos romanos pelo papa Leão III, em Roma. Além disso, esse monarca preocupou-se com a administração do seu vasto domínio, com a reorganização eclesiástica e dos mosteiros e com o incentivo ao ensino e algumas atividades culturais em sua corte ${ }^{47}$. Isso levou os reis e imperadores do século $\mathrm{X}$ em diante, tanto no reino germânico como no reino francês, a verem em Carlos Magno um modelo a ser seguido e divulgarem a sua condição de herdeiros do grande imperador. As Canções de Gesta constituíram uma forma de preservação dessas lembranças, tornadas lendárias, difundindo-as para grupos mais extensos da população, fossem estes membros da aristocracia cavaleiresca ou não.

O outro grupo é formado pelos poemas sobre as cruzadas iniciadas em 1095, cujo resultado foi a tomada de Jerusalém, em 1099, e neste se inclui ainda a Canção da Cruzada Albigense, pois embora referindo-se a fatos ocorridos no início do século XIII, no sul do reino francês, tem na luta contra os inimigos da fé católica romana o seu tema dominante.

Ao decidirmos quais fontes utilizaríamos, consideramos ser mais produtivo o estudo dos textos de temática carolíngia, pois suas narrativas referem-se mais especificamente ao reino da França, originado da fragmentação do império criado por Carlos Magno e do qual tanto a realeza quanto a aristocracia das terras ocidentais se consideravam herdeiros e descendentes. Além disso, para as mentalidades dos jograis e de seu público, o reino

mais atuais para a descrição e a história das Canções de Gesta. Isto motivou o seu uso preferencial na composição desta parte de nosso trabalho.

${ }^{47}$ HALPHEN, Louis. Charlemagne et l'empire carolingien. Paris: Albin Michel, 1979, p. 57-194. 
francês teria sido o principal e o líder daquela criação imperial, conduzida por essa realeza tornada quase mítica, a dos Carolíngios, e cuja lembrança era ainda enaltecida no tempo da monarquia capetíngia. Mas convém observarmos que embora as Canções se afirmem como efetivamente "históricas", de fato elas são anacrônicas, pois não descrevem os tempos do império Carolíngio como de fato eles teriam sido. Os séculos VII-X são pensados e organizados de modo a se parecerem com o mundo ocidental dos séculos XIIXIII, nos hábitos, nas vestimentas, nas armas, nas formas de combate, na estrutura política. Trata-se de uma representação idealizada de um passado visto como o apogeu da Cristandade ${ }^{48}$.

Uma Canção de Gesta é formada por conjuntos de estrofes irregulares, chamadas de laisses. Um poema pode apresentar uma grande variação no número de versos em cada uma de suas laisses. Assim, a Chanson de Roland apresenta cinco versos na laisse 51 e 30 versos na laisse 185. Mas, no poema Huon de Bordeaux, encontramos apenas três versos nas laisses 48 e 49 enquanto há 1.140 versos na laisse 74. Também varia a quantidade total de versos no texto dos poemas. Enquanto Voyage de Charlemagne à Jérusalem et à Constantinople conta 870 versos em seu todo, Renaut de Montauban, na versão do manuscrito Douce, apresenta 14.310 versos. Houve uma tendência à amplificação das Canções no decorrer dos séculos XII e XIII, da qual é testemunha a própria narrativa da Chanson de Roland, pois seu manuscrito mais antigo, o de Oxford, tem 4.002 versos ${ }^{49}$ enquanto os manuscritos Châteauroux - Veneza 7, de fins do século XIII, apresentam 8.204 e 8.397 versos $^{50}$.

A língua predominante das Canções de Gesta é o românico das regiões do norte do reino da França, a chamada langue d'oil (Normandia, Champagne, Picardia). Muitos poemas foram escritos no dialeto anglo-normando e penetraram na Inglaterra sob os reis de origem normanda ou angevina. Poucas narrativas foram escritas na língua corrente no sul

\footnotetext{
${ }^{48} \mathrm{Na}$ recriação do mundo carolíngio feita pelas Canções de Gesta existiram apenas quatro monarcas dessa dinastia: Carlos Martel (714-741), Pepino o Breve (741-768), Carlos Magno (768-814) e Luís o Piedoso (814-840). Os outros monarcas homônimos foram aglutinados a esses quatro nomeados nos textos. Outra característica épica é o nomear os monarcas épicos tanto de "rei" como de "imperador", altenando as duas dignidades para o mesmo personagem durante toda a narrativa, procedimento que mantivemos no transcorrer do nosso texto, quando se tratar de personagens épicos. A coroação de Carlos Mango como imperador, no ano 800, parece ter sido totalmente esquecida pelas Canções de Gesta. Do mesmo modo, a poesia épica qualifica os antigos adversários dos francos, fossem eles os saxões ou os normandos, como sarracenos, o mesmo nome aplicado aos muçulmanos da península Ibérica e da Palestina, nos séculos XI-XIII.

49 LA CHANSON DE ROLAND / The Song of Roland, the French Corpus. Vol. 1: The Oxford Version, edited by Ian SHORT. Turnhout (Belgium): Brepols, 2005, p. I/5-I/338.

50 LA CHANSON DE ROLAND / The Song of Roland, the French Corpus. Vol. 2: The Châteauroux Venice 7 version, edited by Joseph J. DUGGAN. Turnhout (Belgium): Brepols, 2005.
} 
francês, a langue d'oc, e uma das poucas conhecidas é o chamado Roland Occitan ${ }^{51}$. Apesar disso, alguns estudiosos defendem uma origem provençal para a poesia épica francesa ${ }^{52}$.

Os textos mais antigos, como a Chanson de Roland, apresentam laisses assonantes, ou seja, o som final recai sobre a última vogal tônica não importando como se escreve a palavra e as consoantes finais.

Carles li reis, nostre emperere magnes,

Set ans tuz pleins ad estét en Espaigne:

Tresqu'en la mer cunquist la tere altaigne.

$N$ 'i ad castel ki devant lui remaigne ;

Mur ne citét n'i est remés a fraindre

Fors Sarraguce, k'est en une muntaigne.

Li reis Marsilie la tient, $k i$ Deu nen aimet;

Mahumet sert et Apollin recleimet:

Ne s' poet guarder que mals ne l'i ateignet.

$(\text { versos } 1-9)^{53}$

A partir do final do século XII a tendência foi a criação de poemas rimados ou o colocar em rimas as narrativas já existentes. Há manuscritos em que se verifica uma alternância de laisses rimadas e assonantes, caso do poema Renaut de Montauban. Em outros se nota uma tentativa de fazer um remanejamento recente parecer antigo pelo uso da assonância, como ocorre na Canção de Raoul de Cambrai ${ }^{54}$, cuja primeira parte, do início da guerra entre Raul e o clã de Vermandois até a morte do primeiro, constitui a narrativa antiga e está escrita em rimas. Já a segunda parte, da paz provisória entre as linhagens até a morte do escudeiro Bernier, e escrita no final do século XII, é assonante.

Os poemas de temática carolíngia são distribuídos em três Ciclos, segundo uma tradição que remonta ao final do século XII. A Canção de Girart de Vienne, de Bertrand de Bar-sur-Aube, em seu prólogo, já afirmava a divisão ${ }^{55}$ :

n'ot que trois gestes em France la garnie;

ne cuit que ja nus de ce me desdie.

Des rois de France est la plus seignorie, et l'autre aprés, bien est droiz que jeu die, fu de Doon a la barbe florie,

\footnotetext{
${ }^{51}$ ROLAND OCCITAN (Le). Roland à Saragosse; Ronsasvals. Édition et traduction de Gérard GOUIRAN et Roberte LAFONT. Paris : Christian Bourgois, 1991.

${ }^{52}$ LAFONT, Robert. Les origines occitanes de la chanson de geste: le cas de F(i)erabras. Cahiers de civilisation médiévale, T-41, 1998, p. 365-373.

53 CHANSON DE ROLAND (La). Édition critique et traduction de Ian SHORT. Paris : Le Livre de Poche, 1990, p. 28.

${ }^{54}$ RAOUL DE CAMBRAI. Chanson de geste du XIIe siècle. Introduction, notes et traduction de William KIBLER. Texte édité par Sarah KEY. Paris : Le livre de poche, 1996.

${ }^{55}$ BOUTET, Dominique. Formes littéraires et conscience historique. Paris : PUF, 1999, p. 171-172.
} 
cil de Maience qui molt ot baronnie.

(versos 11-16)

La tierce geste, qui molt fist a prisier,

fu de Garin de Monglenne au vis fier.

$\left(\right.$ versos 46-47) ${ }^{56}$

Esse entendimento foi mantido no poema Doon de Mayence, do início do século XIII.

Bien sceivent li plusor, n'en sui pas em doutanche, Qu'il n'éut que.III. gestes u réaume de Franche:

Si fu la premeraine de Pepin et de l'ange,

L'autre après, de Garin de Monglane la franche,

Et la tierche si fu de Doon de Maience,

.I. chevalier vaillant et de grant sapience.

$(\text { versos } 3-8)^{57}$

Embora sejam possíveis vários tipos de agrupamento de Canções de Gesta, essa divisão em Ciclos adotada pelos autores do medievo nos parece a mais útil para o desenvolvimento de nossas pesquisas. Além disso, é a mais difundida entre os estudiosos da poesia épica francesa, desde o século XIX.

O primeiro Ciclo é identificado como "do rei" ou "de Carlos Magno" e narra as aventuras do grande imperador desde a sua concepção (Berte aux-grans-piès) até a sua morte, com atenção especial às guerras movidas pelo monarca épico na península itálica (Chanson d'Aspremont), na Saxônia (Chanson des Saisnes) e, principalmente, na Península Ibérica (Chanson de Roland, Fierabras, Gui de Bourgogne). Nestes poemas a figura do rei é enaltecida, há um contato direto de Carlos com o mundo celeste através dos anjos guardiões ou mensageiros. O monarca consegue impor sua vontade sem que seus barões se sintam prejudicados ou tentados à revolta ou à desobediência.

Outro Ciclo é o de "Aymeri de Narbonne" ou de "Guilherme de Orange", formado a partir do entrelaçamento de dois grupos distintos de poemas, o referente às aventuras da linhagem narbonesa (Aymeri de Narbonne, Narbonnais, Siège de Barbastre, Guibert de Andrenas, Mort Aimery de Narbonne) e o relacionado às lembranças sobre Guilherme de Tolouse, sobrinho de Carlos Magno convertido em santo com a denominação de Saint Guilhem du Desert (Couronnement de Louis, Charroi de Nîmes, Prise de Orange, Chanson de Guillaume / Aliscans, Moniage Guillaume). A união desses personagens em uma grande família de heróis cavaleiros deve ter ocorrido no início do século XII, de modo

${ }^{56}$ GIRART DE VIENNE, par Bertrand de Bar-sur-Aube. Publié par WOLFGANG VAN EMDEN. Paris : A. et J. Picard, 1977, p. 3-5.

57 DOON DE MAIENCE, Chanson de Geste. Publiée pour la premiére fois d'après les manuscrits de Montpellier et de Paris par M. A. PEY. Paris : F. Vieweg, 1859, p. 1. 
que há uma integração muito bem feita entre as narrativas. O tema principal destes poemas é a fidelidade do clã Aymerida ao monarca franco, em especial o fraco Luís, o filho de Carlos Magno que não herdara o caráter enérgico do pai. A linhagem, e particularmente Guilherme, protege o seu rei contra usurpadores e invasores pagãos. Também são responsáveis pela dilatação do império cristão sobre as terras sarracenas, atribuição régia da qual Luís procurava eximir-se.

O último Ciclo é chamado de "Doon de Mayence" ou dos "Vassalos Rebeldes", apesar deste designativo ser desconhecido dos autores medievais. É o conjunto de poemas mais diversificado com relação aos personagens (Chevalerie Ogier de Danemarche, Raoul de Cambrai, Gaufrey, Macaire). Enquanto o "Ciclo do Rei" se apega à figura de Carlos Magno e o "Ciclo de Guilherme de Orange" restringe suas narrativas aos feitos de sua linhagem, o "Ciclo de Doon de Mayence" comporta as aventuras de diversos cavaleiros cujo laço de união é a luta contra o monarca, em geral decorrente de uma falta deste para com seu vassalo. Verificamos neste grupo uma divisão por "subciclos", com alguns poemas narrando as aventuras de uma família de barões ou cavaleiros específica, caso do “Ciclo de Nanteuil" (Aye d'Avignon, Gui de Nanteuil, Parisse la Duchesse) e o "Ciclo dos Lorenos" (Garin le Loherenc, Guibert de Metz, Hervis de Mes).

As Canções de Gesta circularam do século XI ao século XV e essa longevidade deveuse não apenas ao interesse pelas histórias cantadas, mas também pela capacidade de jograis e poetas incluírem nos poemas temas copiados de outros gêneros em românico, em especial através do aprimoramento dos personagens femininos e do papel do amor, sem que a poesia épica perdesse o seu belicoso vigor. Do século XV em diante verificou-se um processo de prosificação dessas Canções, pois os textos poéticos como forma de contar o passado perdera sua atração, enquanto a prosa ganhava respeito como forma de conservar e transmitir a história do reino da França. O período no qual a épica francesa esteve mais em voga foi do final do século XI até fins do século XIII, quando a maioria das narrativas foi criada e, em muitos casos, fixada definitivamente. Mas da metade do século XIII até fins do século XIV poucas Canções foram escritas e estas usavam a época carolíngia para enquadramento dos personagens e suas ações, tornados elementos principais da narrativa, e esmaecendo a figura do monarca. Alguns textos se apresentam como "Canções de Aventuras" e não mais de "feitos heroicos". Uma crise político-social também podia incentivar a criação épica tardia, como ocorreu com o poema Hugues Capet, voltado à narrar uma versão da ascensão dos capetíngios, e escrita pouco depois da crise de 1356-58, 
como resposta à derrota de João II o Bom na batalha de Poitiers para os ingleses e da revolta de Étienne Marcel, em Paris ${ }^{58}$.

As Canções de Gesta eram feitas para recitação pública. Elas eram cantadas acompanhadas por um instrumento de cordas e em sua apresentação celebrava heróis do passado, suas proezas, e era uma forma de manter viva a história dos francos entre seus descendentes franceses ${ }^{59}$. Apesar de dispormos de manuscritos dos poemas épicos, a sociedade na qual eles foram criados e difundidos era predominantemente oral, especialmente no que se refere às línguas vulgares. A oralidade influenciou grandemente o desenvolvimento das Canções, mantendo um caráter flexível e variável nas suas narrativas. Quem colocou por escrito os poemas costumava exaltar a própria obra frente à de outros jograis, estes itinerantes, os quais eram tratados de forma depreciativa e tinham seus poemas vilipendiados como mentirosos ou incorretos. Havia muita competição entre jograis e cada um tentava mostrar seu trabalho como superior ao de seus concorrentes.

O termo jogral designava indivíduos muitas vezes desenraizados, em constante movimento, que circulavam por rotas diversas oferecendo algum tipo de entretenimento a quem quisesse vê-los em ação e, principalmente, pagasse por isso. Podiam ser dançarinos, cantores, acrobatas, adestradores de animais, mágicos, prestidigitadores. Alguns se especializavam como cantadores de histórias, não apenas épicas. Frequentavam lugares onde houvesse aglomeração de pessoas e estas demandassem alguma distração frente à monotonia dos dias ou ao final das lides diárias. Feiras, locais de peregrinação, cidades, vilas, torneios, acampamentos guerreiros serviam de pontos de atração para os jograis e, caso conseguissem agradar, obtinham recursos para manter-se e às suas famílias. Alguns deles conseguiam a proteção na corte de um senhor laico e tornavam-se menestréis, passavam a divertir ao seu patrono, aos seus vassalos e hóspedes, ganhando assim um sustento menos aleatório.

O público das Canções de Gesta devia ser bem variado, pois em feiras e cidades havia pessoas das mais diversas categorias. Um clérigo e tratadista do fim do século XIII, Jean de Grouchy, descreveu essa poesia como feita para idosos, pessoas humildes e trabalhadores, que ao ouvirem as narrativas de sofrimento dos outros eram levados a

\footnotetext{
${ }^{58}$ HUGUES CAPET. Chanson de geste du XIV siècle. Editée par Noëlle LABORDERIE. Paris : Honoré Champion, 1997, p. 9-12. DEMURGER, Alain. Temps de crises, temps d'espoirs, XIVe-XVe siècle. Paris : Seuil, 1990, p. 20-34.

59 Nas narrativas das Canções de Gesta alternam-se os designativos «Franc» (franco) e «Français» (francês), os quais são considerados equivalentes pelo poeta e pelo seu público para nomear os guerreiros cristãos, em especial os mais próximos do imperador, e o Carlos Magno épico é qualificado tanto de "rei dos francos" como de "rei dos franceses".
} 
suportar suas infelicidades e a executar bem seus afazeres ${ }^{60}$. As Canções eram feitas para gerar uma resposta emotiva do público, a aprovação ou censura das ações de personagens encarados como modelos de conduta. Pelo que pudemos observar em nossas leituras, os mais interessados na poesia épica eram os membros da ordem cavaleiresca, pois estes podiam ver nas narrativas a representação de sua atividade. Ouvir sobre o padecimento físico durante uma batalha e sobre o ato de cavalgar para enfrentar um adversário, sobre a alegria de uma vitória, devia gerar uma resposta emotiva muito mais forte naqueles habituados com as experiências ali descritas. Feita para um grupo de guerreiros de elite, senhores e vassalos, as Canções continham as representações e sonhos dessa aristocracia belicosa. A visão de mundo da poesia épica era própria dos cavaleiros e, também, ela apresentava um ideal cavaleiresco adaptado para o reino quase mítico dos carolíngios, oposto muitas vezes à situação concreta dos séculos XII e XIII, quando a força desses aristocratas refluia diante do poder ascendente da monarquia capetíngia.

O clero, tanto o secular quanto o regular, olhava com muitas reservas e mesmo condenavam a atividade dos jograis. Para a Igreja esses elementos desenraizados podiam representar uma ameaça aos seus fiéis, pois os distraía das preocupações importantes, sendo a primeira de todas elas a salvação da própria alma. Danças e músicas podiam ser licenciosas e, portanto, condenáveis. No entendimento dos bispos e padres, o público dos jograis estaria sendo afastado das missas, dos atos de piedade e dos clérigos e abandonando seus guias e pastores espirituais ${ }^{61}$. Mesmo os poemas épicos podiam ser censurados por gerar essa distração, como também ocorria com as histórias arturianas ou de Tristão e Isolda. No século XIII alguns tratadisdas, envolvidos com a aplicação de penitências aos fiéis, tentaram separar em grupos os profissionais da diversão envolvidos ou não com a licenciosidade, para que seus penitenciais abrangessem o maior número de atividades possíveis. Os beneficiados seriam os cantadores dos antigos monarcas e dos santos e mártires. As Canções seriam assim colocadas no mesmo patamar que a hagiografia ${ }^{62}$.

Quanto à execução das Canções de Gesta junto a monarquia capetíngia, na corte régia, isso não parece ter existido. Embora a realeza pudesse fazer uso do lendário épico carolíngio, sua aliança com a Igreja priorizava narrativas desenvolvidas pelos meios eclesiásticos, como a abadia de Saint Denis. Apesar do período mais rico da poesia épica coincidir com o reinado de Felipe Augusto (1180-1223), este monarca não simpatizava

\footnotetext{
${ }^{60}$ SUARD, F. Guide de la chanson de geste ..., p. 25.

${ }^{61}$ FARAL, Edmond. Les jongleurs en France au Moyen Âge. Genève : Slatkine, 1987, p. 25-43.

${ }^{62}$ Ibid., p. 44-60.
} 
com os jograis, pois estes trabalhavam com narrativas constantemente alteradas, algo totalmente diferente do que acontecia com as obras escritas e transmitidas pelo clero, este visto como responsável pela fixação do passado ${ }^{63}$. Além disso, as Canções de fins do século XII e início do século XIII não eram lisongeiras para com os reis épicos e isto podia refletir na imagem da realeza governante, cujas ações preocupavam os príncipes e senhores territoriais, então protetores dos jograis. Mas há pesquisadores convencidos da ligação entre estabelecimentos religiosos próximos à monarquia com alguns autores de textos épicos. Assim, H.-E. Keller defendeu, em alguns artigos, ter sido a Chanson de Roland uma forma de propaganda em favor dos Capetíngios criada e difundida a partir da abadia de Saint Denis ${ }^{64}$. Teria havido, inclusive, um ciclo voltado à explicação das origens das relíquias existentes nesse mosteiro e os poemas Fierabras e Voyage de Charlemagne à Jérusalem et à Constantinople seriam os exemplos desse projeto da abadia.

Sobre as origens da poesia épica francesa, rios de tinta já correram sem que se chegasse a uma conclusão definitiva. A atenção sobre ela como objeto de estudo deu-se no século XIX, quando os diversos países europeus desenvolviam o seu nacionalismo e buscavam resgatar as suas origens, através da coleta de documentos. Isto significava enaltecer suas qualidades em detrimento das dos povos de além-fronteiras. Para a França a origem das Canções de Gesta tinha um peso especial e as ideologias nacionalistas podiam ter efeitos duradouros, principalmente após a derrota na guerra franco-prussiana de 1870-1871.

A primeira teoria sobre o surgimento das Canções foi chamada de "Tradicionalista" e baseava-se na crença de que as mesmas tinham uma origem muito antiga, de cunho popular e herdeira de uma tradição épica germânica de celebração dos heróis guerreiros. $\mathrm{Na}$ época dos próprios eventos narrados diversos cantos curtos, chamados de cantilenas, deviam ter sido criados para homenagear os heróis envolvidos. Tais obras seriam oriundas do povo, interessado em ouvir e preservar na memória os fatos marcantes e os personagens cujos atos foram admirados pelos membros da sua sociedade. Isso era reconhecido como uma característica dos conquistadores germânicos do império romano que, sem ter uma escrita para conservar seu passado, dedicavam-se à transmissão oral e à memória para não perder os feitos de seus antepassados. As cantilenas, curtas quando expressas pela primeira vez, à época dos acontecimentos, eram formas simples de celebrar

\footnotetext{
${ }^{63}$ MORRISSEY, Robert. L'Empereur à la barbe fleurie. Charlemagne dans la mythologie et l'histoire de France. Paris: Gallimard, 1997, p. 102-121.

${ }^{64}$ KELLER, Hans-Erich. Autour de Roland. Recherches sur la chanson de geste. Paris: Champion, 1989, p. 37-92.
} 
a batalha de Roncesvales (788), o cerco de Vienne (870), as lutas de Guilherme de Toulouse contra os sarracenos, no sul da França. Com o passar do tempo os pequenos poemas foram ampliados, episódios e novos personagens incluídos, contos distintos reunidos para formar uma narrativa longa. Esse processo teria levado à formação das Canções de Gesta como são conhecidas hoje. Leon Gautier (1832-1897) ${ }^{65}$ e Gaston Paris $(1839-1903)^{66}$ defenderam essa posição e exerceram influência sobre os pesquisadores da segunda metade do século XIX.

Todavia, alguns estudiosos consideravam a teoria Tradicionalista demasiado "romântica", feita para agradar o sentimento de amor-próprio popularizante e afastada da realidade e dos elementos textuais e históricos existentes nas Canções de Gesta. Mas somente no início do século XX a reação ao Tradicionalismo obteve um partidário vigoroso na pessoa de Joseph Bédier (1864-1938). Em suas obras, em especial nos quatro volumes do Les légendes épiques ${ }^{67}$, Bédier procurou mostrar, a partir do estudo dos textos disponíveis, como era recente a poesia épica francesa, surgida quando muito no início do século XI e, sendo o mais provável, entre a metade e o final desse mesmo século. Como não era possível provar documentalmente a existência de uma tradição oral, a opção plausível era de que as lembranças dos eventos narrados nas Canções estavam inscritas nos anais e crônicas guardados nos santuários, mosteiros e catedrais espalhados pelo território do reino da França e anteriormente parte do império carolíngio. Para atrair peregrinos a esses locais, os clérigos e, principalmente, os monges passaram a divulgar as narrativas de heróis laicos cujos comportamentos piedosos do final de suas vidas levaram a doar seus bens, inclusive armas e suas próprias pessoas aos mosteiros. A divulgação das histórias foi deixada a cargo de jograis encarregados de propagar as aventuras dos beneficiadores desses estabelecimentos religiosos e incentivar seu público a visitar o local onde eles estariam enterrados ou onde eram conservados os seus pertences pessoais. Outro fator a impulsionar os mosteiros foi a retomada das ações guerreiras cristãs contra os muçulmanos na Península Ibérica. Os monarcas cristãos peninsulares mantiveram relações com os condes e duques franceses, da Borgonha, da Provença, da Normandia. Solicitaram, com

${ }^{65}$ GAUTIER, Léon. Les épopées françaises. Étude sur les origines et l'histoire de la littérature nationale. Paris: T-I, Société Générale de Librairie Catholique, 2e édition, 1878; T-II, Librairie Universitaire H. Welter, 1894; T-III, Paris: Société Générale de Librairie Catholique, 1880; T-IV, Paris: Société Générale de Librairie Catholique, 1882.

${ }^{66}$ PARIS, Gaston. Histoire poétique de Charlemagne. Paris: A. Franck, 1865.

${ }^{67}$ BÉDIER, Joseph. Les légendes épiques. Recherches sur la formation des Chansons de Geste. Paris: Honoré Champion, 4 Tomes, 1908-1913. 
frequência, combatentes para expandir os seus territórios e obtiveram o apoio da abadia de Cluny nessa empreitada. Poemas que lembravam as ações bélicas conduzidas contra os pagãos nos tempos de Carlos Magno teriam sido um estímulo à participação dos cavaleiros do século XI, pois estes estariam dando continuidade a uma obra pia em favor da religião. O ponto alto dessa propaganda seria a expedição de 1095 a 1099, dirigida não mais à Espanha, mas sim em direção ao Oriente, para "libertar" Jerusalém dos infiéis. Assim, para Bédier, as Canções de Gesta só poderiam ter surgido no século XI, em decorrencia do espírito de Cruzada então em formação e pela associação de monges e jograis na criação e difusão dos poemas. Como os mosteiros, com suas relíquias, serviam de guardiões das lembranças e centros de propagação da lenda carolíngia, as rotas de peregrinação é que teriam dado origem aos poemas épicos, de modo a fazer das Canções de Gesta uma das primeiras e mais importantes obras na nascente língua francesa, e indicariam a possível existência de alguma forma de nacionalismo "francês" antigo.

Durante a primeira metade do século XX a teoria "Individualista" dominou os estudos sobre as origens das Canções de Gesta e, por vezes, seus adeptos tentaram ultrapassar os limites impostos pelo próprio Bédier. Assim, Pauphilet via um poema como o Gormont et Isembart como a obra pessoal de um poeta de gênio, um criador literário consciente de sua condição, e isto excluía a necessidade de uma aliança entre monges e jograis ${ }^{68}$.

Obviamente que nem todos os estudiosos se filiaram ao Individualismo dominante. Ferdinand Lot $^{69}$ e Robert Fawtier ${ }^{70}$ questionaram o papel determinante dos mosteiros na produção épica. Também não acreditavam terem as Canções de Gesta surgido do nada, já prontas, no século XI. Pare eles, deviam ter existido antecedentes narrativos antes dos textos conservados e a própria constituição destes marcaria uma parte do processo de formação paulatina da épica francesa.

Por volta de 1950 houve uma reação às teorias de Bédier e uma adaptação da teoria Tradicionalista. Isso em parte se devia aos trabalhos de estudiosos espanhóis como Martín de Riquer $^{71}$ e Ramón Menéndez-Pidal ${ }^{72}$. Estes retomaram a ideia de uma gestação prolongada das Canções de Gesta, na qual tanto as histórias quanto os procedimentos narrativos teriam se formado. $\mathrm{O}$ papel do poeta genial não era minimizado por estes

\footnotetext{
${ }^{68}$ PAUPHILET, Albert. Sur la Chanson d'Isembart. Romania, T-50, 1924, p. 161-194.

${ }^{69}$ LOT, Ferdinand. Études sur les légendes épiques françaises. Paris: Honoré Champion, 1970.

${ }^{70}$ FAWTIER, Robert. La Chanson de Roland. Étude historique. Paris: Boccard, 1933.

${ }^{71}$ RIQUER, M. de. Los cantares de gesta franceses, sus problemas, su relación con España. Madrid: Gredos, 1952.

${ }^{72}$ MENÉNDEZ-PIDAL, Ramón. La Chanson de Roland et la tradition épique des Francs. Paris: A. et J. Picard, 1960, 2e. édition.
} 
pesquisadores, mas esse gênio individual era devedor de toda uma tradição anterior voltada a celebrar as aventuras de heróis dos tempos carolíngios. Chamada de "Neotradicionalista", essa teoria deu novo impulso aos estudos épicos, em especial com o trabalho de Jean Rychner ${ }^{73}$, que se preocupou em mostrar como a estrutura das Canções de Gesta, com suas fórmulas, repetições e motivos, caracterizariam uma literatura onde a oralidade predominaria, tanto na criação quanto na transmissão dos poemas.

Existe ainda, nos dias de hoje, alguma preocupação com a origem das Canções de Gesta, mas esse tipo de estudo tem perdido importância frente a novos questionamentos feitos aos poemas. Embora narrando histórias do tempo dos carolíngios, a ambientação das Canções é a vigente nos séculos XII e XIII, salvo algum arcaísmo mantido nos textos. A poesia épica francesa falava do tempo no qual ela circulava, da sociedade, das relações entre monarquia e aristocracia, dos hábitos e das crenças aceitas. Segundo Emanuel J. Mickel, ela refletiria no passado esse presente, tornando o ontem igual ao hoje e justificando as ações cristãs, como a guerra contra os muçulmanos. Para a disciplina de história, Jean Flori tentou deixar bem clara a utilidade da poesia épica:

O que pode esperar um historiador do nosso tempo do estudo das canções de gesta? Muito! Pois a epopeia, como a arte românica à qual a associamos frequentemente, traduz com uma grande fidelidade as instituições políticas, as estruturas sociais e a atividade econômica de uma época, mas mais ainda seus modos, seus costumes e suas ideologias. ${ }^{74}$

Desse leque amplo, para nós, o conteúdo ideológico representa o elemento mais interessante nas Canções de Gesta, não apenas por expor um ideal cavaleiresco e aristocrático, mas também por apresentar questionamentos e posições políticas extraídas do pensamento agostinista ${ }^{75}$. Elas estabeleciam em seus textos um modelo de monarquia cristã e feudal, criticando ao mesmo tempo condutas dos monarcas que não condiziam com essa idealização. Dominique Boutet já notara essa característica na épica francesa, cuja atenção às relações entre rei e vassalo marcara a própria questão da divisão e do exercício do poder no reino da França ${ }^{76}$.

${ }^{73}$ RYCHNER, Jean. La chanson de geste: essai sur l'art épique des jongleurs. Genève; Lille: Droz; Girad, 1955.

${ }^{74}$ FLORI, J. L'historien et l'épopée française. In : VICTORIO, Juan. L'épopée. Turnhout - Belgium : Brepols, 1988, p. 92 (tradução nossa).

${ }^{75}$ ARQUILLIËRE, H.-X. L'Augustinisme politique: essai sur la formation des théories politiques du Moyen Age. Paris: Vrin, 1972, 2e. édition.

${ }^{76}$ BOUTET, Dominique. Les chansons de geste et l'affermissement du pouvoir royal (1100-1250). Annales ESC, 1982, nº 1, p. 3-14. 
A versão da Chanson de Roland do manuscrito de Oxford é datada de 1060 a 1100, coincidindo com o reinado de Felipe I o Gordo na França. O período era de extrema fraqueza da monarquia capetíngia, incapaz de impor-se perante os seus grandes vassalos e, em consequência, limitada a agir apenas buscando o fortalecimento dos seus domínios pessoais. Na passagem do século XII para o XIII, alterações haviam ocorrido e o rei tentava sobrepor-se aos grandes senhores territoriais, o que incomodava a estes, ciosos de sua independência. Acompanhando as alterações nas relações de poder, as Canções de Gesta também mudaram a forma de apresentar os entendimentos e desentendimentos entre senhor e vassalo, o tipo de respeito que cada um devia manter para com o outro e os rompimentos entre eles, dos quais a consequência era o conflito armado.

A poesia épica francesa apresenta antecedentes datados do final do século X. Ela desenvolveu-se no decorrer dos séculos XI-XIII e começou a declinar na metade do século XIV. É notável a concordância entre este gênero literário e a história da dinastia dos Capetos "diretos" (987-1328). Embora falando de Carlos Magno e de seus homens, as Canções tinham à sua frente a realeza governante de seu tempo. É desta família, a dos Capetíngios, da sua ascensão e de suas conquistas políticas que trataremos agora.

\section{2- A monarquia capetíngia}

Em 987 falecia em um acidente de caça o último rei carolíngio da Francia Occidentalis, Luís V, cognominado “o Menino" (l’Enfant). Ainda muito jovem e solteiro, ele não deixou um herdeiro e os grandes do reino reunidos em uma assembleia, incentivados pelo bispo Adalberon de Reims, elegeram para governa-los o duque dos Francos, Hugo Capeto, iniciando a história da dinastia capetíngia, que veria a sucessão ininterrupta de pai para filho até $1314^{77}$. Mesmo as dinastias posteriores, a dos Valois ou a dos Bourbon, eram ramos originários desta linhagem.

Esse evento em 987 pôs fim também a uma luta secular e ao revezamento no trono de duas famílias, a dos carolíngios cujo prestígio era devido à tradição sucessória iniciada em 751 e à lembrança do grande imperador Carlos Magno, e a dos robertíngios, da qual Hugo Capeto era descendente, alçados ao poder na França Ocidental em momentos de crise. A linhagem Robertíngia recebeu esse nome do seu mais antigo representante, Roberto o Forte, herói das lutas contra os normandos no século IX, tendo morrido em batalha contra

\footnotetext{
${ }^{77}$ LUCHAIRE, Achille. Les premiers Capétiens (987-1137). Paris : Tallandier, 1980, p. 152-161. SASSIER, Yves. Hugues Capet. Paris: Fayard, 1987, p. 177-198.
} 
esses invasores. Seus filhos Eudes e Roberto, herdeiros das terras e honras de seu pai, continuaram a atividade guerreira deste e obtiveram, além do aumento do seu patrimônio fundiário, o respeito dos demais chefes do reino. Ao mesmo tempo os carolíngios viam diminuir, juntamente com as suas terras, o seu prestígio. O vasto império de Carlos Magno e de Luís o Piedoso deixara praticamente de existir em 843, pelo tratado de Verdun, no qual Carlos o Calvo ficou com a Francia Occidentalis, Luís o Germânico com a Francia Orientalis e Lotário com o título imperial e um conjunto de terras entre as de seus irmãos e que acabariam anexadas ao reino oriental ou Germania ${ }^{78}$.

Em 885 houve uma momentânea reunificação do império sob Carlos o Gordo ${ }^{79}$, mas quando este morreu a divisão se confirmou e, com o passar dos anos, cada reino acabou escolhendo um governante que não pertencia à linhagem carolíngia, cujos representantes desapareciam sem deixar sucessores ${ }^{80}$. Na Germânia, Conrado I da Francônia assumiu o trono, em 911, e após sua morte a dinastia dos Otônidas tomaria as rédeas do poder no Leste $^{81}$. No ocidente os grandes príncipes territoriais elegeram Eudes, o filho de Roberto o Forte, como rei (888-898). Mas, nesta época, uma mudança dinástica definitiva no reino ocidental não se mostrou viável e, quando Eudes morreu, o carolíngio Carlos o Simples (898-929) foi coroado. A sua falta de habilidade política levou a uma revolta dos grandes que escolheram Roberto, irmão do falecido rei como seu senhor (922) e, apesar da morte deste no decorrer da luta, em 923, Carlos não conseguiu firmar-se no poder, pois nesse mesmo ano foi aprisionado pelo conde Herbert do Vermandois e a coroa acabou indo para um aliado dos Robertíngios, Raul da Borgonha. Com a morte deste último, em 936, Hugo o Grande resolveu entregar o trono a um descendente de Carlos Magno, Luís IV de Ultramar, que até então vivia na Inglaterra, e assumiu uma posição de conselheiro e mentor do novo monarca. Essa política foi seguida pelo duque e por seu filho, Hugo Capeto, em relação aos reis carolíngios posteriores, Lotário (954-986) e Luís V (986-987) ${ }^{82}$.

Quando se deu efetivamente a mudança dinástica, em 987, esta não ocorreu sem problemas, pois havia um descendente de Carlos Magno, Carlos da Baixa Lorena, tio de Luís V e vassalo dos imperadores germânicos Otônidas. A assembleia que escolheu Hugo como rei descartou este outro pretendente, o qual tentou obter pela força a coroa por considerá-la um direito seu. Capturado em Laon (991), graças à traição do bispo desta

\footnotetext{
${ }^{78}$ HALPHEN, Louis. Op. cit., p. 265-356.

${ }^{79}$ Ibid., p. 383-400.

${ }^{80}$ BRÜHL, Carlrichard. Naissance de deux peuples. Paris : Fayard, 1994, p. 175-190.

${ }^{81}$ Ibid., p. 182-210.

${ }^{82}$ SASSIER. Hugues Capet. p. 55-132.
} 
cidade, Adalberon, Carlos morreria prisioneiro e não haveria outras contestações à nova monarquia eleita ${ }^{83}$. No final do século $X$ a ascensão de Hugo Capeto não foi vista como uma usurpação, mas como uma necessidade de manter a coesão do reino ocidental. Se durante o século XI surgiram lendas que faziam do primeiro capetíngio um usurpador elas surgiram entre os grupos em confronto com a monarquia e interessadas em enfraquecê-la ${ }^{84}$, mas nunca houve a intenção de derrubar a família reinante e substituí-la por outra linhagem senhorial.

A primeira preocupação de Hugo Capeto foi de garantir que a função régia continuaria na sua linhagem. Para isso associou ao trono o seu filho Roberto, recorrendo à sagração antecipada deste. Isto não era uma inovação, pois já fora usada pelos carolíngios no decorrer do século $\mathrm{X}$. Com este procedimento tentava-se evitar a eleição de alguém oriundo de outra família senhorial e opor-se de forma não muito aberta ao princípio eletivo da função régia no qual o papel dos grandes senhores territoriais era decisivo. Os capetíngios mantiveram a sagração antecipada do seu herdeiro e a associação deste ao governo até o reinado de Felipe Augusto, sendo este o primeiro a dispensar esse costume em relação ao seu herdeiro, Luís VIII.

Mas apesar de Hugo Capeto ter obtido a coroa real para a sua linhagem e garantido a passagem dela aos seus descendentes, os meios pelos quais o seu poder podia ser exercido ou exibido estavam limitados. Em 987 o patrimônio do novo monarca vira-se muito reduzido e alguns dos grandes do reino dispunham de recursos maiores do que o seu rei. Hugo sabia não possuir força o bastante para impor-se aos príncipes territoriais, mas foi hábil o suficiente para manter suas conquistas e no uso das relações de fidelidade vassálica quando havia necessidade de enfrentar pelas armas os adversários interessados em prejudica-lo, fosse o concorrente Carlos da Baixa Lorena ou o ameaçador conde Eudes de Blois.

Roberto II o Piedoso (996-1031) tentou seguir a política de seu pai, mas alterou uma aliança essencial ao aproximar-se da linhagem de Blois em detrimento da dos condes de Anjou. Também soube usar os princípios vassálicos para conduzir a sua longa guerra na Borgonha (1002-1016) e usar do prestígio sagrado da realeza para adquirir uma vantagem moral forte para contrabalançar sua fraqueza material ${ }^{85}$. Os dois primeiros monarcas

\footnotetext{
${ }^{83}$ LUCHAIRE. Op. cit. p. 152-159; SASSIER. Hugues Capet. p. 194-236

${ }^{84}$ SASSIER. Op. cit. p. 11-21. A história escrita por Richer de Reims, a única que efetivamente é datada da época da ascensão de Hugo Capeto, esteve desaparecida durante séculos, não foi conhecida durante a Idade Média e só foi descoberta em 1833.

${ }^{85}$ THEIS, Laurent. Robert le Pieux. Le roi de l'An mil. Paris : Perrin, 2008.
} 
capetíngios ainda conseguiam apresentar-se com alguma autoridade diante de seus vassalos, como continuadores da antiga monarquia carolíngia, apesar das perdas patrimoniais sofridas com o intento de obter o apoio necessário à superação das dificuldades de seus reinados ${ }^{86}$. Mas tal situação se alterou nos reinados seguintes de Henrique I e de Felipe I o Gordo.

Henrique I (1031-1060) assumiu definitivamente o trono, logo após a morte de Roberto o Piedoso, mas encontrou seus adversários mais perigosos não entre os grandes do reino e sim dentro de sua própria família. Sua mãe, Constança, desejava ver coroado o filho mais novo e tentou impor sua vontade através da revolta contra o primogênito. Henrique superou essa ameaça com apoio do duque da Normandia, Roberto II o Magnífico ${ }^{87}$. O monarca capetíngio procurou mostrar alguma atividade militar, como era esperado de quem exercia uma função como sua, e assim apoiou ao novo duque da Normandia, Guilherme o Bastardo, contra as graves rebeliões orquestradas por alguns barões normandos (1044-1047). Entretanto, na maior parte de seu reinado, Henrique viu diminuir a sua força material e militar enquanto a dos grandes senhores territoriais aumentava e, iniciativa das mais graves, ele rompeu a aliança até então mantida com os duques da Normandia, por recear o fortalecimento excessivo do jovem Guilherme ${ }^{88}$. Quando o rei faleceu, deixou um filho menor de idade, Felipe, sob a tutela do conde de Flandres, Balduino V.

Boa parte da historiografia legou uma imagem nada lisonjeira de Felipe I o Gordo $(1060-1108)^{89}$. Em seu longo reinado foi acusado de simonia e de intrometer-se nos assuntos dos bispados e mosteiros sob sua guarda, justamente quando a Igreja romana lutava para extirpar esse mal das eleições episcopais e mesmo abaciais, assim como procurava impedir toda e qualquer interferência laica nos assuntos eclesiásticos. Enquanto Guilherme da Normandia conquistava a Inglaterra (1066) e os primeiros cruzados partiam para a Terra Santa (1096), Felipe recolheu-se em suas terras. Mantendo com Bertrada de Montfort uma relação matrimonial condenada pela Igreja, deixou-se excomungar e viu seus domínios colocados sob o interdito eclesiástico. Entretanto, observe-se não ter este monarca um auxiliar que lhe escrevesse uma obra de cunho laudatório, como seu filho teve em Suger, o abade de Saint-Denis, e muito se exagerou sobre o seu mau governo para

\footnotetext{
${ }^{86}$ LUCHAIRE. Op. cit., p. 183-187.

${ }^{87}$ GOBRY, Ivan. Henri Ier., 1031-1060. Paris : Pygmalion, 2008. O estudo deste reinado é considerado difícil pela ausência de documentos escritos. O pouco que existe não é favorável a Henrique I.

${ }^{88}$ GOBRY. Ibid, p. 138-146; LUCHAIRE. Op. cit., p. 170-172.

${ }^{89}$ GOBRY, Ivan. Philippe Ier., 1060-1108. Paris: Pygmalion, 2006.
} 
contrastar com o de seu herdeiro. No caso da simonia, estava em jogo mais o direito de eleição de bispos e abades do que propriamente a venda de cargos. Como as funções da Igreja também envolviam a detenção de propriedades terrenas e a disposição de guerreiros, a monarquia usava essas dignidades para ter meios materiais e humanos para opor-se aos senhores laicos. Em 1066, quando o duque da Normandia se tornou rei da Inglaterra, Felipe ainda era muito jovem e estava sob a tutela do conde de Flandres. Em 1095, quando Urbano conclamou a Cruzada, o rei da França estava excomungado devido à sua relação adúltera com Bertrada. Quanto à sua insistência em não deixar esta mulher, convém lembrar que o casamento entre os grandes na França medieval envolvia interesses de linhagens e a obtenção de alianças para fazer frente a outras famílias poderosas. Mas não há dúvida de que a monarquia francesa viu seu poder e prestígio limitados durante o seu reinado, sem forças para impor sua vontade aos diversos senhores territoriais do reino e ameaçada dentro dos próprios domínios pessoais do rei por vassalos e castelões turbulentos.

Podemos observar que apesar de terem ascendido ao trono pela vontade dos grandes do reino, através de uma eleição (987), e de dispor de menos recursos materiais e humanos em relação aos seus subordinados, os primeiros capetíngios, de 987 até 1108 , não tiveram o seu direito à condição régia ameaçada de forma grave. Eles obtiveram o apoio dos vassalos envolvidos na sua aclamação para enfrentar as pretensões do carolíngio Carlos da Baixa Lorena. Conseguiram essa mesma ajuda para conquistar a Borgonha (1002-1016) ou para fazer frente a determinados potentados, cujas ações ameaçavam o equilíbrio de poderes dentro do reino. Os senhores territoriais não ambicionavam a coroa e, portanto, não representavam um perigo de golpe contra os reis Capetos. O único vassalo a conseguir a dignidade régia, Guilherme da Normandia, dirigiu seus esforços para a Inglaterra e sempre manteve uma postura de respeito para com seu senhor da França, mesmo após este mover-lhe ações hostis.

É comum afirmar que com a ascensão de Luís VI o Gordo (1108-1137) a monarquia francesa começou a reagir de modo a impor-se aos seus vassalos, fossem estes os pequenos castelões do domínio real ou os grandes detentores de terras do reino. O próprio Felipe I incumbira seu filho de conduzir as forças reais contra os cavaleiros perturbadores da paz. Após a morte do pai, Luís obteve o apoio de alguns potentados como o conde de Flandres, e viu-se logo em conflito com outros, em especial os duques normandos e reis da Inglaterra Guilherme o Ruivo e Henrique I Beauclerc. Nem sempre os confrontos foram favoráveis ao monarca capetíngio, pois tanto a habilidade militar como a superioridade em recursos 
materiais e humanos esteve do lado de seus adversários. Além disso, as alianças matrimoniais entre as diversas casas senhoriais criavam mais de uma frente de combate para o Capeto. Henrique Beauclerc tinha laços de parentesco com Thierry de Blois e este se mostrou um inimigo encarniçado do rei francês ${ }^{90}$. E na Vida de Luís VI o Gordo, escrita pelo abade Suger de Saint-Denis, há uma menção na qual um adversário pretendera usurpar a coroa da França, no caso o rei da Inglaterra Guilherme o Ruivo ${ }^{91}$ que, ao contrário do irmão Henrique Beauclerc, não deixou uma imagem positiva pelas mãos dos clérigos.

Apesar dos percalços, Luís VI conseguiu controlar os vassalos de seus domínios e os de domínios eclesiásticos sob sua proteção, para criar uma base sólida de onde poderia tirar recursos visando outros objetivos. Também conseguiu se mostrar como alguém superior aos seus vassalos, como detentor de uma função à qual todos deviam unir-se em caso de ameaça ao reino ou diante de uma crise grave. A ameaça ao reino veio em 1124, quando o imperador germânico Henrique V, na tentativa de intimidar a França pelo apoio dado ao papa, reuniu um exército para invadir as terras submetidas aos capetíngios. Luís VI convocou todos os vassalos para enfrentar as forças imperiais e, em uma cerimônia em Saint-Denis, tomou a oriflama (oriflamme), bandeira tornada símbolo da realeza e do reino, ato simbólico para mostrar a união geral contra o invasor ${ }^{92}$. Mesmo Thierry de Blois, continuamente em oposição ao rei, apresentou-se à hoste, obrigado pela sua condição de vassalo.

Quanto à crise, ela ocorreu em Flandres, em 1127, quando o conde Carlos o Bom foi assassinado por alguns de seus vassalos, temerosos de terem seu poder rebaixado diante da acusação de serem de origem servil. Luís reuniu um exército, uniu-se àqueles que desejavam punir os assassinos e comandou o cerco ao reduto dos traidores, a captura e a execução destes. Também foi o rei francês quem garantiu a eleição do novo conde, Guilherme Cliton, e apesar deste ter sido depois repudiado por parte dos castelões e das cidades de Flandres, a supremacia régia acabou reconhecida no final da contenda pois, após a morte de Guilherme Cliton, em 1128, seu adversário Thierry da Alsácia, reconheceu-se vassalo de Luís VI para assumir a dignidade condal ${ }^{93}$. Antes de falecer, Luís conseguiu o casamento de seu filho e herdeiro com Eleonora, herdeira da Aquitania, o

\footnotetext{
${ }^{90}$ BOURNAZEL, Éric. Louis VI le Gros. Paris : Fayard, 2007.

${ }^{91}$ SUGER. Vie de Louis VI le Gros. Éditée et traduite par Henri WAQUET. Paris : Les belles lettres, 2007 , p. 4-13.

92 BOURNAZEL. Op. cit., p. 167-171. PETIT-DUTAILLIS, Charles. La monarchie féodale en France et en Angleterre. Paris : Albin Michel, 1971, p. 88-89.

${ }^{93}$ BOURNAZEL. Op. cit., p. 179-190.
} 
que duplicava o território sob o controle capetíngio. Política e materialmente esse matrimônio traria muitas vantagens para a monarquia, na visão de Luís o Gordo e de seus conselheiros, incluindo Suger.

Ao ascender ao trono Luís VII o Jovem poderia continuar a tarefa de seu pai, mas seu reinado tomou um rumo próprio. O novo monarca só assumira a função régia em decorrência do falecimento do primogênito Felipe, ocorrido em $1131^{94}$. A acentuada devoção e o gosto pelas cerimônias litúrgicas de Luís VII indicariam que ele estava destinado a uma carreira eclesiástica, mas as obrigações para com a linhagem levaram-no a tomar o lugar do irmão primogênito. No início do reinado o jovem monarca foi belicoso e obrigou o velho inimigo dos Capetos, Thibaut de Blois a fazer um acordo de paz $(1144)^{95}$. Surpreendendo a muitos, o rei da França planejou ir defender os reinos latinos na Palestina, ameaçados pelos muçulmanos, talvez devido ao remorso decorrente da tragédia de Vitry, onde centenas de pessoas morreram queimadas em uma igreja durante um ataque das forças reais ${ }^{96}$. O projeto teve o apoio do papa e de São Bernardo de Claraval e, logo, o imperador germânico Conrado III se uniu à expedição. Entretanto, todo o esforço em materiais, homens e tempo redundou em derrota das forças cristãs, em Damasco (1148). Luís levara Eleonora nessa expedição e muitos cronistas dizem que a mulher do rei comportou-se de modo inconveniente na Sicília e em Trípoli. Isso conturbou a já difícil relação do casal régio, pois este, apesar de anos de matrimônio, ainda não havia gerado um herdeiro para o trono ${ }^{97}$. O resultado final seria a anulação do casamento do rei e da duquesa da Aquitania, em 1152.

Luís VII foi censurado por esses "fracassos", mas o sucesso da cruzada dependia de um entendimento entre cavaleiros europeus recém-chegados e os herdeiros dos conquistadores ocidentais instalados na Palestina. Isso não havia e más decisões foram tomadas devido à rivalidade entre os príncipes cristãos no Oriente. Quanto a Eleonora, esta ficou pouco tempo só, casando-se com Henrique II Plantageneta, conde do Anjou, duque da Normandia, e depois rei da Inglaterra e senhor da Bretanha, e estes domínios, junto com a Aquitania, criariam o chamado "império" Plantageneta. Entretanto, dadas as veleidades de independência dos vassalos aquitanos e os recursos escassos do Capeto, não parece possivel ter este condições de torna-se o poder dominante no sul da França tal como ele o era em seus domínios na Ile-de-France. Mesmo os Plantagenetas, apesar da sua riqueza, da

\footnotetext{
${ }^{94}$ Ibid., p. 194-196.

${ }^{95}$ LUCHAIRE, Achille. Philippe Auguste et son temps. Paris : Tallandier, 1980, p. 14-19.

${ }^{96}$ PETIT-DUTAILLIS. Op. cit., p. 98.

97 SASSIER, Yves. Louis VII. Paris: Fayard, 1991, p. 183-189.
} 
sua habilidade política e militar, perdiam seu tempo combatendo revoltas na região do Midi. Foi movendo guerra para impor-se a um vassalo do Limoges, durante o cerco a um castelo, e pouco depois de fazer uma trégua com Felipe Augusto, em 1199, que Ricardo Coração de Leão perdeu a vida ${ }^{98}$.

Mas não se pode dizer ter sido o reinado de Luís VII desfavorável às pretensões monárquicas. Para começar, o sistema vassálico permitiu ao monarca obter o apoio dos barões para opor-se a algum adversário ameaçador, em especial ao expansionismo da linhagem Plantageneta. O próprio Henrique II evitava conduzir uma ação que significasse confrontar diretamente do rei francês, pois aumentaria a oposição dos outros príncipes territoriais aos seus projetos e, principalmente, poderia incentivar atos de hostilidade dos seus próprios vassalos. Talvez fosse devido a esse temor e/ou o respeito ao seu senhor feudal o motivo da renúncia de Henrique em atacar a cidade de Toulouse, em 1159, onde Luís havia adentrado para tentar proteger o conde Raimundo $\mathrm{V}^{99}$. Quanto à cruzada de 1147-1149, se ela não trouxe frutos, ao menos o rei capetíngio teve a oportunidade de mostrar-se diante dos seus súditos mais distantes e para os habitantes de outros reinos e terras como o chefe inconteste do reino da França. Sua fidelidade à Igreja trouxe apoio não apenas dos chefes eclesiásticos das regiões francesas, mas também do próprio papado. Além disso, durante sua prolongada ausência o reino foi dirigido pelo abade de Saint Denis, Suger, não tendo havido nenhuma revolta que ameaçasse os direitos do monarca. Retornando da Terra Santa, Luís promulgou uma legislação para todo o seu reino, tentando transformar a antiga Paz de Deus pregada pela Igreja em uma "paz do rei", e o fato de sua aplicação depender da boa vontade dos senhores regionais não deixava de marcar o desejo régio de ser o legislador máximo nas terras a ele teoricamente subordinadas ${ }^{100}$.

Outra preocupação de Luís VII decorreu da necessidade de manter a França como reino independente e não submisso a um império germânico cujo dirigente, na pessoa de Frederico Barba-Ruiva, desejava ver a ele submetidos, mesmo se fosse apenas simbolicamente, todos os reinos cristãos do Ocidente. Se não houve luta armada entre o rei e o imperador, em diversos encontros diplomáticos, tentou-se fazer do reino francês uma parte do império e, portanto, obrigado a aceitar as decisões imperiais. Exemplo dessas tentativas de submissão ocorreu no encontro de Saint-Jean-de-Losne, em 1162,

\footnotetext{
${ }^{98}$ FLORI, Jean. Richard Coeur de Lion. Le roi-chevalier. Paris : Payot, 1999, p. 231-255.

99 LUCHAIRE. Philippe Auguste ..., p. 46-47.

${ }^{100}$ GRABOIS, Aryeh. De la trêve de Dieu à la paix du roi. In: Mélanges offerts à René Crozet, edités par Pierre GALLAIS et Yves-Jean RIOU. Poitiers: Société d’Études Médiévales, 1966, Tome I, p. 585-596.
} 
onde um grupo pró-imperial da corte francesa quase fez do seu rei um vassalo de Frederico $^{101}$.

Se Luís VI o Gordo concentrou seus esforços no efetivo controle de seus domínios, combatendo seus vassalos da Ile-de-France, e na tentativa de mostrar-se superior aos grandes príncipes territoriais do norte, seu filho levou sua presença aos diversos cantos do seu reino, quer em ações militares quer, principalmente, através de suas peregrinações aos diversos santuários da França ou fora dela (Santiago de Compostela, Cantuária ${ }^{102}$ ). Embora não detivesse um poder material e humano efetivo, Luís VII fortalecera o prestígio da monarquia capetíngia e isto era uma garantia não apenas de sua continuidade, mas também de possível expansão posterior ${ }^{103}$.

Quando o monarca faleceu, em 1180, deixou um filho menor, Felipe $\mathrm{II}^{104}$, em torno do qual duas linhagens disputaram a tutela, a casa da Champagne, a qual pertencia Adélia, a mãe do novo rei, e a casa de Flandres, cujo chefe, o conde Felipe da Alsácia, fora designado como tutor para guardar seu jovem senhor e, aproveitando-se disso, casou este com uma sobrinha sua, Isabela (ou Elisabete) do Hainaut ${ }^{105}$. Mas, ao contrário do que esses príncipes territoriais pensavam, Felipe II não era alguém disposto a aceitar o controle dos outros e, mais ainda, estava convicto de exercer um ministério régio com aura sagrada. Para enfrentar as duas casas senhoriais, unidas contra ele entre 1181 e 1184, o jovem monarca aliou-se ao mais poderoso potentado do reino, Henrique II Plantageneta, e com isso superou sua primeira crise. Mas não demorou muito para o rei se desentender com seu aliado angevino e de iniciar a guerra para eliminar o "império" Plantageneta, cuja existência e poder eram vistos como uma ameaça ao domínio capetíngio e à própria existência dessa monarquia. Os melhores aliados encontrados por Felipe estavam na própria família de Henrique II, os seus filhos Henrique o Jovem, Ricardo Coração de Leão, Godofredo da Bretanha e João Sem Terra. Com estes apoiando seu adversário, o velho rei criador da potência anglo-normando-angevina acabou sendo obrigado a reconhecer a derrota e faleceu, em 1189. As relações entre Felipe II e o novo senhor Plantageneta, Ricardo, logo se tornaram hostis e só não houve uma guerra imediata devido ao voto de

\footnotetext{
${ }^{101}$ LUCHAIRE. Philippe Auguste ..., p. 48-55; SASSIER. Louis VII, p. 307-328.

${ }^{102}$ A peregrinação de Luís VII ao túmulo de Thomas Becket, na catedral da Cantuária, em 1173, deveu-se a uma enfermidade que atingiu seu filho Felipe. FLORI, Jean. Philippe Auguste. La naissance de l'État monarchique. Paris : Tallandier, 2007, p. 23-24.

${ }^{103}$ MENANT, F.; MARTIN, H.; MERDRIGNAC, B.; CHAUVIN, M. Les Capétiens, 987-1328. Paris : Perrin, 2008, p. 280-281.

104 FLORI, Jean. Philippe Auguste. Paris : Tallandier, 2007.

${ }^{105}$ SASSIER. Louis VII, p. 467-473.
} 
ambos os monarcas de marcharem para a Palestina para retomar Jerusalém, reconquistada pelos muçulmanos sob o comando de Saladino, em 1187. A expedição ao invés de arrefecer, acirrou as desavenças entre os reis dadas as suas diferenças de temperamento e de riqueza. Felipe adoeceu e abandonou o exército cruzado logo após a tomada de São João d'Acre e retornou para a França, em 1192, enquanto Ricardo via sua glória aumentar, embora seu objetivo maior, de conquistar novamente a Cidade Santa, não tivesse exito.

Quando Felipe voltou à França começou a negociar com João Sem Terra um acordo contra Ricardo. Este, ao retornar da Palestina, foi capturado pelo duque Leopoldo da Áustria, a quem tinha humilhado no cerco de São João d'Acre, e entregue ao imperador germânico Henrique $\mathrm{VI}^{106}$. O rei francês se aproveitou do incidente para ocupar partes importantes da Normandia e de outros domínios Plantagenetas no continente e tentando abrir a possibilidade de João tornar-se monarca inglês no lugar do irmão. Mas com o pagamento de um imenso resgate, arrecadado por sua mãe Eleonora, Ricardo pode voltar para a Inglaterra e deu início a uma feroz guerra contra o rei francês. A luta entre o Plantageneta e o Capetíngio foi de uma violência pouco vista anteriormente, com o uso de mercenários e o massacre ou mutilação de guarnições inimigas como regra. Mesmo se alguém importante era capturado e fosse oferecido um resgate pela sua libertação esta poderia não ocorrer preferindo-se manter o adversário preso indefinidamente, caso do bispo de Beauvais, Felipe de Dreux, a quem Ricardo considerava um inimigo mortal. Até 1199 a vantagem esteve com o rei da Inglaterra que além de bom guerreiro e líder de tropas dispunha de recursos materiais e humanos superiores aos de Felipe. Também foi capaz de fazer várias alianças com outros príncipes territoriais franceses de modo a reduzir a capacidade militar do Capetíngio e criar-lhe novas preocupações de defesa. Uma trégua foi acertada, em 1199, com a intermediação do papado, este interessado em montar nova expedição para o Oriente, com os dois reis à frente. Entretanto, pouco tempo após o acordo Ricardo era ferido no cerco de um castelo pertencente a um vassalo seu na Aquitânia e sua morte deu a Felipe tempo para reorganizar suas forças e, melhor ainda, colocou à sua frente um adversário muito inferior ao falecido rei inglês, pois João Sem Terra assumira a coroa inglesa e os títulos baroniais e condais do continente, sem ter as qualidades de comando e o carisma do irmão.

Aproveitando-se dos erros cometidos por João diante dos seus vassalos, Felipe conseguiu condena-lo, em 1202, à perda das suas terras francesas, por não cumprimento de

${ }^{106}$ FLORI. Richard Coeur de Lion, p.181-209. 
suas obrigações vassálicas para com o rei da França. A Normandia foi conquistada e também o Anjou, a Tourenne, o Maine e a Bretanha. O Poitou ofereceu maior resistência, revoltando-se sempre que o Plantageneta João vinha enfrentar o Capetíngio ${ }^{107}$. A luta, apesar de favorável a Felipe Augusto, estendeu-se até 1214, quando este conseguiu uma vitória militar decisiva em Bouvines, derrotando não apenas João Sem Terra, mas ainda a Ferrand de Flandres e Renaut de Dammartin, conde de Boulogne, e ao imperador germânico Oto de Brunswick ${ }^{108}$. Expulso de quase todas as terras continentais o Plantageneta logo teria que lutar contra seus vassalos da Inglaterra, até sua morte, em 1216.

Outra região aos poucos submetida ao monarca francês foi o Languedoc dos condes de Toulouse, onde a difusão da heresia cátara levou a Igreja a temer a perda do seu monopólio religioso. Felipe não assumiu o comando de uma expedição contra o sul, mas permitiu que os barões de seus domínios participassem da conquista do Midi, liderados por Simão de Montfort, a partir de 1209. Posteriormente deixou o seu filho e herdeiro Luís participar desse empreendimento, só encerrado em 1229, pelo tratado de Paris. Neste acordo foi selado o casamento de Alfonso, um dos filhos de Luís e Branca de Castela, com Joana, filha de Raimundo VII, e única herdeira do condado, abrindo a possibilidade de uma anexação futura do Languedoc ao domínio real ${ }^{109}$.

O reinado de Luís VIII (1223-1226) foi movimentado apesar de muito curto ${ }^{110}$ e a sua morte desencadeou um levante baronial, favorecido pela menoridade do sucessor, objetivando bloquear o aumento do poder monárquico e sua capacidade de intervir nas grandes propriedades feudais. A revolta fracassou, pois a rainha viúva conseguiu o apoio dos barões dos domínios reais, dos bispos e da população em geral para enfrentar essa ameaça. Isso garantiu a coroação de Luís IX livre das pressões particularistas dos grandes senhores territoriais ${ }^{111}$.

A primeira parte do reinado de Luís IX deu-se sob a tutela ou conselho de sua mãe Branca de Castela e envolveu o confronto constante com barões revoltosos, apoiados pelo rei inglês Henrique III, esperançoso de recuperar as antigas possessões continentais de sua família. Ele era estimulado a isso pelo fato de restar nessas terras muitos simpatizantes dos

\footnotetext{
${ }^{107}$ PETIT-DUTAILLIS. Op. cit., p. 209-217.

${ }^{108}$ DUBY, Georges. Le dimanche de Bouvines. Paris : Gallimard, 1985.

${ }^{109}$ BOUTARIC, Edgard. Saint Louis et Alfonse de Poitiers. Paris : Henri Plon, 1870.

${ }^{110}$ SIVÉRY, Gérard. Louis VIII le Lion. Paris : Fayard, 1995.

111 LANGLOIS, Charles-Victor. Saint Louis, Philippe le Bel, les derniers Capétiens directs (1226-1328). Paris : Tallandier, 1978, p. 3-19.
} 
Plantagenetas, capazes de tomar armas contra os Capetíngios. Esses conflitos só acabaram após a derrota de Henrique III em Taillebourg (1242) e a submissão definitiva de Raimundo VII de Toulouse, em $1243^{112}$.

Entretanto, o maior projeto do jovem monarca francês foi o de libertar a cidade de Jerusalém dos muçulmanos. Contrariando seus conselheiros, seus barões, o clero e até sua mãe, Luís preparou e conduziu uma primeira expedição ao Egito (1248-1254) para forçar os líderes islamitas do Cairo a abandonar a Cidade Santa. Apesar dos sucessos iniciais, como a tomada de Damieta, a empreitada acabou fracassando e o rei foi capturado junto com boa parte de seu exército. Depois de pago seu resgate, Luís ainda ficou alguns anos no Oriente e, apesar da morte de sua mãe (1252), que ficara como regente na França, somente em 1254 decidiu-se a voltar para seu reino. Uma segunda expedição, em 1270, agora direcionada ao norte da África, contra a cidade de Túnis, também não foi bem sucedida e desta vez o próprio monarca acabou morrendo no decurso da Cruzada ${ }^{113}$. Se não foi possível uma vitória militar, ao menos os Capetíngios obtiveram uma grande vitória moral e, acompanhando esta, um prestígio político considerável, pois seu rei morrera como mártir sendo rapidamente canonizado (1297). O fato de ter um santo na linhagem régia traduzia-se em maior influência nas relações políticas com os outros reinos europeus e mesmo diante do papado.

Outra preocupação desse rei, especialmente após seu retorno da Palestina, foi com relação à justiça. Segundo a doutrina agostinista, corrente no pensamento clerical da maior parte da Idade Média, era obrigação do monarca garantir a justiça para os homens a ele subordinados e assim conduzir o seu povo à salvação, conforme prega o Cristianismo. Se a imagem passada através dos séculos foi a de São Luís sentado debaixo de um carvalho, julgando pessoalmente os pedidos de justiça de qualquer pessoa, outras ações tinham efeitos políticos maiores. Assim as enquetes levadas a efeito nos domínios diretamente administrados pelos bailios e senescais do rei, para corrigir abusos e erros destes funcionários reais ${ }^{114}$. Isso também foi aplicado por Alfonso de Poitiers no Languedoc para dar conta dos excessos cometidos contra a população do Midi durante e depois da conquista levada a efeito através da Cruzada Albigense. Dentro dessa premissa de justiça estava também o acordo feito com Henrique III da Inglaterra, em 1259, a quem era cedido o ducado da Gasconha, com Bordeaux como centro principal. Criticado por muitos, Luís

\footnotetext{
${ }^{112}$ SIVÉRY, Gérard. Saint Louis et son siècle. Paris : Tallandier, 1983, p. 374-397.

${ }^{113}$ MENANT; MARTIN; MERDRIGNAC; CHAUVIN. Op. cit., p. 463-473; PETIT-DUTAILLIS. Op. cit., p. 275-277. SIVÉRY. Saint Louis ..., p. 405-469.

${ }^{114}$ PETIT-DUTAILLIS, Op. cit., p. 287-290; SIVÉRI. Saint Louis ..., p. 158-224..
} 
respondeu que desse modo terminava com um conflito entre parentes (eles eram concunhados, seus filhos primos), fazia vigorar a paz no reino e regularizava a condição de Henrique como seu vassalo ${ }^{115}$.

Aos duelos judiciários, condenados pela Igreja, o rei francês deu preferência aos procedimentos inquisitoriais, nos quais as provas materiais e os testemunhos substituíam as práticas nas quais se pedia a intervenção divina. Um caso marcante neste ponto foi o processo de Enguerrand de Couci, acusado de enforcar injustamente três jovens alemães por caçarem em suas terras. Embora o barão quisesse bater-se em duelo, foi adotado o modo inquisitório na corte e Enguerrand só não foi concenado à morte por pressão de outros barões, mas teve que ceder muitos direitos ao rei como compensação ${ }^{116}$.

Com o falecimento de São Luís ascendeu ao trono Felipe III o Ousado (1270-1285) ${ }^{117}$, figura apagada, mas em cujo reinado deu-se continuidade aos procedimentos dos Capetíngios anteriores, como o progresso da justiça real e aquisições territoriais de interesse da monarquia. Começou a manifestar-se, no seu tempo, um aumento nas necessidades financeiras e o recurso a expedientes que viessem a levantar recursos. Sua morte durante uma Cruzada contra o rei de Aragão levou ao trono seu filho, Felipe IV o Belo, e chegava-se talvez ao apogeu da dinastia dos Capetos "diretos".

Sob Felipe o Belo (1285-1314) a monarquia francesa criou novas bases para a administração do reino, fazendo um contínuo uso dos chamados legistas, homens formados nas faculdades de direito da França e da Itália, imbuídos dos ensinamentos oriundos do direito romano e totalmente dedicados a servir aos interesses do monarca. Diversas foram as crises enfrentadas pelo Capeto, da guerra em Flandres à falta de recursos financeiros, da luta contra o papa Bonifácio VIII à perseguição e condenação daqueles que fossem vistos como suspeitos de atos contrários ao rei, ao reino ou à religião. Uma das armas utilizadas por Felipe foi a chamada dos súditos para tomarem conhecimento das decisões régias, através convocação de assembleias das ordens do reino, nas quais era apresentado um resumo do problema - no mais das vezes transmitido de forma a levar os participantes a tomar o partido de seu senhor - e solicitado um parecer sobre as medidas a serem adotadas para enfrentar ou resolver a questão. Tal procedimento mostrou-se útil principalmente na luta contra Bonifácio VIII, pois o apoio das ordens do reino respaldavam as medidas até mesmo truculentas usadas para vencer o papa. Talvez a força da monarquia capetíngia

${ }^{115}$ JOINVILLE. Vie de Saint Louis. Texte établi et traduit par Jacques MONFRIN. Paris : Garnier, 1995, p. 184-185.

${ }^{116}$ PETIT-DUTAILLIS. Op. cit, p. 300-301.

${ }^{117}$ SIVÉRY, Gérard. Philippe III Le Hardi. Paris : Fayard, 2003. 
ficasse demonstrada claramente nesse episódio, pois o monarca francês conseguiu o que os imperadores germânicos não conseguiram em dois séculos, derrotar um papa e barrar o princípio da plenitude do poder defendido pelo papado, o qual colocava o pontífice, pela sua função espiritual, como superior a todos os monarcas laicos, cuja função era meramente terrena ${ }^{118}$.

Após a morte de Felipe o Belo a realeza capetíngia começou a passar por séria crise não tanto devido às revoltas dos grandes senhores territoriais, mas sim pelo falecimento sucessivo dos seus três filhos. Luís X o Rixento (1314-1316) ${ }^{119}$, Felipe V o Longo (13161322) ${ }^{120}$ e Carlos IV o Belo (1322-1328) ${ }^{121}$ não reinaram tempo bastante e nenhum deles deixou um filho homem como herdeiro para substituí-los. Com a morte de Carlos IV extingue-se também o ramo direto dos Capetos, que vinha governando ininterruptamente desde Hugo Capeto e transmitindo a coroa de pai para filho. Os grandes do reino recorreram a um dos ramos laterais para obter um novo rei. Felipe de Valois, sobrinho de Felipe o Belo, suplantou a concorrência de outros senhores importantes, em especial do jovem Eduardo III, rei da Inglaterra e nascido do casamento de Isabela da França, filha de Felipe IV, com Eduardo II. Apesar da mudança dinástica não houve uma crise na administração do reino francês, pois as estruturas criadas e aperfeiçoadas em duzentos anos garantiam a estabilidade para governar a França. Somente na metade do século XIV, quando as disputas entre os monarcas francês e inglês chegaram a um nível de violência exacerbado, caminhando para o início da Guerra dos Cem Anos, foi questionada por Eduardo III, já adulto, a legitimidade da coroação de Felipe VI.

A dinastia Capetíngia governou a França de 987 a 1328, período no qual as Canções de Gesta surgiram, se difundiram, se transformaram e atingiram seu apogeu. Colocaram os reis de Saint Denis como personagens importantes e indispensáveis, personificados nos monarcas carolíngios. A presença constante destes nos poemas fazia com que seus personagens sofressem a influência das conjunturas existentes no tempo e no espaço onde as Canções foram criadas, cantadas ou passadas para os textos. Nesse ponto a poesia épica francesa apresenta-se como uma maneira de expor uma forma de pensamento político e defender uma organização política ideal para a sociedade feudo-vassálica na qual ela circulou. Seus heróis foram tirados do passado quase mítico dos carolíngios, mas a

\footnotetext{
${ }^{118}$ FAVIER, Jean. Um roi de marbre. Philippe le Bel. Enguerran de Marigny. Paris : Fayard, 2005.

${ }^{119}$ GOBRY, Ivan. Louis X, 1314-1316. Paris : Pygmalion, 2010.

${ }^{120}$ GOBRY, Ivan. Philippe V, 1316-1322. Paris : Pygmalion, 2010

${ }^{121}$ GOBRY, Ivan. Charles IV le Bel, 1322-1328. Paris : Pygmalion, 2011
} 
representação expressa nos poemas era própria dos séculos XI, XII e XIII, na qual governaram os Capetíngios "diretos".

Em fins do século X havia um conjunto de lendas sobre Carlos Magno, Luís o Piedoso e os diversos outros heróis que teriam servido sob esses monarcas. O material para a poesia épica estava ainda se acumulando no século X, bastando lembrar o poema Raoul de Cambrai $^{122}$, cujo evento que incitou a Canção teria ocorrido em 943, quando Raoul de Gouy, incentivado pelo rei Luís IV de Ultramar, invadiu as terras de Herbert do Vermandois e encontrou a morte em combate. Quanto a análise da Canção de Gesta cuja versão é considerada a mais antiga, a Chanson de Roland do manuscrito de Oxford (10601100), há indícios da existência de um conjunto de lendas sobre Roncesvales no século X e alguns estudiosos defendem essa posição observando nas listas de testemunhas em documentos, do início do século XI em diante, os nomes de Olivier e de Rolando, dados a irmãos ${ }^{123}$. A história do companheirismo desses combatentes já circulava quando Hugo Capeto subiu ao trono.

Quando as Canções de Gesta começaram a ser escritas, os monarcas capetíngios não dispunham de recursos suficientes para impor-se aos grandes príncipes territoriais. Seus domínios eram inferiores aos de muitos de seus vassalos. A poesia épica, opondo-se a essa realidade, apresentou um Carlos Magno condutor de grandes exércitos e senhor inconteste do império cristão. A obrigação do monarca em seguir o parecer dos conselheiros, na Chanson de Roland, pode bem ser uma crítica à ausência de poder do rei para impor sua vontade. As decisões das assembleias dos vassalos foram prejudiciais a Carlos, ao exército franco e à Cristandade.

O respeito ao monarca ficou presente em outros poemas como o Couronnement de Louis $^{124}$, o Fierabras $^{125}$ e mesmo a Chanson des Saisnes de Jehan Bodel ${ }^{126}$. No Couronnement de Louis há discursos tanto do poeta quanto de Carlos Magno que defendem uma realeza forte e um rei capaz de impor sua vontade e de punir quem o desafiasse. Como o jovem Luís não tinha temperamento para isso o poema acaba defendendo dois princípios, o primeiro, a hereditariedade da função régia. O segundo, o

\footnotetext{
${ }^{122}$ RAOUL DE CAMBRAI, p. 17-20.

123 AEBISCHER, Paul. Trois personnages em quête d'auteurs: Roland, Olivier, Aude. In : Rolandiana et Oliveriana. Genève : Droz, 1967, p. 141-173.

124 COURONNEMENT DE LOUIS (Le). Chanson de geste du XIIe. siècle, éditée par Ernest LANGLOIS. Paris: Champion, 1984, 2e. édition.

${ }^{125}$ FIERABRAS. Chanson de geste du XIIe. Siècle. Éditée par Marc LE PERSON. Paris: Champion, 2003.

${ }^{126}$ JEAN BODEL. La chanson des Saisnes. Édition critique par Annette BRASSEUR, Genève: Droz, 2 vols., 1989.
} 
dever dos vassalos servirem ao seu rei, não importa o caráter deste. Os Capetíngios também desejaram e se esforçaram para manter a coroa dentro de sua família, passando-a de pai para filho, como também exigiram sempre de seus vassalos o cumprimento de suas obrigações $^{127}$.

A partir de Luís VI, os grandes senhores feudais viram seus suseranos fortalecer seu poder e imiscuir-se cada vez mais nos assuntos de seus senhorios, o que gerou apreensão entre os grandes vassalos. Isso se acirraria quando da ascensão de Felipe II Augusto (1180). Este monarca usou, por meio de alianças, uma casa aristocrática contra a outra, aproveitou-se dos problemas de sucessão de certos condados, decorrentes da falta de herdeiros quando morria seu titular. Exerceu controle sobre o casamento das filhas de seus vassalos para poder infiltrar seus homens de confiança nos grandes senhorios. Moveu guerras duras contra os Plantagenetas e não recuou em descumprir suas obrigações como senhor vassálico, quando isso podia ajudar a enfraquecer seu poderoso subordinado. É justamente quando de sua ascensão ao trono que Bertrand de Bar-sur-Aube remaneja a Canção Girart de Vienne. A maior parte dos poemas escritos após o Girart de Vienne vão mostrar um rei arrogante, injusto, belicoso, vingativo e incapaz de controlar-se e manter uma postura condizente com sua função.

A tendência foi para um rebaixamento do caráter de Carlos Magno, acentuando o seu autoritarismo e sua complacência para com alguns vassalos bajuladores, oriundos da linhagem de Ganelon, e mesmo esta sofrendo remanejamento por parte de jograis e poetas. Em Renaut de Montauban e em Gaydon verificamos justamente esses dois sentidos, o do rei iracundo, vingativo, incapaz de perdoar e ludibriado pelos Ganelidas, que se apresentam como fiéis vassalos e desejosos de cumprir a vontade de seu senhor. Talvez o poema mais negativo em relação ao Carlos Magno épico seja o Huon de Bordeaux ${ }^{128}$, pois no seu final é o personagem Auberon, o anão senhor de um mundo feérico, quem faz justiça, pois Carlos se mostrara incapaz disso. Desejoso de vingar a morte de seu filho às mãos de Huon, o imperador rejeitara todas as alegações que atenuavam o crime e, intencionalmente, negou-se a cumprir sua promessa de perdoar Huon caso este executasse uma série de provas impostas para confirmar sua inocência.

\footnotetext{
${ }^{127}$ HUNT, Tony. L'inspiration idéologique du Charroi de Nîmes. Revue belge de philologie et d'histoire. TLVI, 1978, n 3, p. 580-606; VAN WAARD, R. Le Couronnement de Louis et le principe de l'hérédité de la couronne. Neophilologus, Vol. 30, 1946, p. 52-58.

${ }^{128}$ HUON DE BORDEAUX. Édition biligue établie, traduite, présentée et annotée par William W. KIBLER et François SUARD. Paris: Honoré Champion, 2003. Poema datado de cerca de 1260, nós o citamos, embora não faça parte do nosso corpus de estudo, por essa característica do rei não ter mais competência para aplicaçar a justiça em seu reino.
} 
Essa forma de mostrar um rei cheio de imperfeições na poesia épica, não tinha por finalidade criar uma animosidade dos cavaleiros e barões contra seu régio senhor. A Canção de Gesta era cantada como forma de entretenimento e a conduta dos reis épicos tornava os poemas mais dramáticos e cheios de peripécias. Nenhuma Canção pregava ou insinuva que a deposição do monarca seria a solução de uma crise. Também mostravam como ato vergonhoso atacar ou ferir o rei. Os estudos de Pierre Le Gentil sobre os poemas Chevalerie Ogier e Girart du Roussillon deixam bem clara a situação do vassalo prejudicado pelo seu monarca e um conflito resultante. No caso do Girart, Carlos Martel por não suportar a força concorrente de seu vassalo, move-lhe várias guerras sem justificativa válida. Entretanto o barão foi derrotado militarmente e, juntamente com a esposa, obrigado a viver como um simples carvoeiro em uma floresta até arrepender-se de ter lutado contra seu rei. Este seria detentor de um poder superior ao dos demais homens, poder atribuído por Deus, portanto era ilícito combatê-lo ou mesmo competir em poderio com ele ${ }^{129}$. O caso de Ogier foi mais complicado, pois envolveu a morte do filho deste pelas mãos do filho de Carlos Magno. O rei se negou a entregar o assassino para o Dinamarquês exercer seu direito de vingança e começou um luta feroz e impiedosa entre o senhor e seu vassalo. No final, Carlos, diante de uma ameaça de invasão pagã, teve que chamar Ogier em sua ajuda e este exigiu primeiro o exercício do seu direito de vingança. Mas, quando levantou a espada, um anjo segurou o seu braço e o proibiu de tocar no filho do rei, pois ambos eram sagrados e, portanto, fisicamente invioláveis ${ }^{130}$.

Essa oscilação de respeito e oposição ao monarca ficou presente em muitos poemas, do final do século XII em diante, não importa o Ciclo ao qual pertençam. Mas quando as Canções de Gesta declinaram no gosto da sociedade francesa medieval e quando os Capetos diretos já não existiam, foi escrito um poema épico para justificar a ascensão de Hugo Capeto, na tentativa de criar algum tipo de união entre cavaleiros e burgueses para enfrentarem a crise decorrente da Guerra dos Cem Anos e para manterem o respeito ao monarca da dinastia Valois ${ }^{131}$.

A monarquia capetíngia e as Canções de Gesta existiram e se desenvolveram ao mesmo tempo. Por tratar de um rei de Paris ou de Saint Denis ${ }^{132}$ a poesia épica podia falar

\footnotetext{
${ }^{129}$ LE GENTIL, Pierre. Girard de Roussillon, sens et structure du poème. Romania, T-78, 1957, p. 328-389; 463-510.

${ }^{130}$ LE GENTIL, Pierre. Ogier le Danois, héros épique. Romania, T-78, fasc. 310, 1957, no 2, p. 199-233.

${ }^{131}$ HUGUES CAPET, chanson de geste du XIVe. siècle. Éditée par Noëlle LABORDERIE. Paris: Honoré Champion, 1997.

${ }^{132}$ É frequente encontrarmos nos textos das Canções de Gesta as expressões "rois de Saint Denis" ou "roi de Paris" empregadas para designar Carlos Magno ou outros reis carolíngios épicos.
} 
dos monarcas carolíngios, mas estando presente na mente dos poetas e jograis que as produziram e cantaram os reis de seu tempo, os Capetos. Essa relação permite estudarmos as questões políticas do século XI ao século XIV através dessa literatura e entre os problemas trazidos pelos textos épicos franceses estavam o da traição e da infidelidade, convertidas em motivos dominantes em alguns poemas.

\section{3- A traição}

Traição é um termo cujo emprego é muito abrangente. Tem um caráter negativo, qualificando uma ação condenável e prejudicial a alguém individualmente ou a uma comunidade. Se nos atemos aos dias de hoje, podem ser identificadas com esse termo, por exemplo, o adultério, os atos contrários à família, o desrespeito aos amigos, a não observância das regras de determinado grupo ou associação, o prejuízo consciente à empresa onde se trabalha, as ações violentas de cunho político contra a ordem pública, o apoio a um governo estrangeiro contra o próprio país. Trata-se de um ato que envolve tanto a infidelidade do traidor para com as outras pessoas, como a violação dos deveres moralmente ou legalmente exigidos do indivíduo pela sociedade na qual o mesmo vive.

Voltando para a Idade Média, no que se refere às questões legais, políticas e sobre abrangência da traição, F. Pollock e F. W. Maitland deram um parecer tornado clássico e retomado pelos historiadores posteriores cujas obras foram dedicadas a esse tema: "Traição é um crime que tinha uma circunferência vaga e mais de um centro"133. Um desses centros poderia ser a aliança de um homem com os inimigos de sua tribo, comunidade ou país; outro, a quebra dos laços de fidelidade com seu senhor. Nos reinos medievais isto poderia significar o enquadramento como traição de qualquer ato considerado pelo monarca ou seus conselheiros como prejudicial aos seus interesses e nisso estaria presente a desobediência ou o rompimento dos compromissos vassálicos por um subordinado, as ações hostis, guerreiras ou não, ou até mesmo agir de forma desonrosa para com a família do monarca (filhos, mulher, noras) ${ }^{134}$.

É comum considerar a noção de traição medieval como fruto do entrelaçamento das concepções díspares do Império Romano, das tribos germânicas e do Cristianismo. No caso romano havia para os cidadãos a obrigação de fidelidade, devoção e obediência ao

\footnotetext{
${ }^{133}$ POLLOCK, Frederick; MAITLAND, Frederic William. Op. cit., Vol. II, p. 503.

${ }^{134}$ O episódio do adultério das noras do rei Felipe o Belo, em 1314, com a punição cruel dos dois rapazes envolvidos no escândalo é um exemplo dessa aplicação em uma época na qual o monarca dispunha de poder suficiente para conduzir os réus à pena capital. FAVIER. Um roi de marbre, p. 475-477.
} 
Império, este constituído pelo conjunto de instituições, crenças e territórios adquiridos por Roma durante seus séculos de existência, de expansão e de desenvolvimento. O imperador, como representação / personificação da res publica, gozava dos mesmos direitos de respeito devidos a esta. Durante o final do período republicano romano, o Senado se opôs àqueles considerados como uma ameaça pública usando procedimentos excepcionais, criados quando das crises, tal como o chamado Senatus consultum ultimum. Com base nessa decisão senatorial os acusados de ameaçar a res publica eram proscritos, colocados fora da proteção das leis romanas e, portanto, podiam ser executados sem que isto parecesse uma abuso ${ }^{135}$. Foi assim em relação aos Gracos quando estes tentaram aprovar medidas contrárias aos interesses dos patrícios e à tradição política defendida pelos senadores. O mesmo ocorreu em relação à Conjuração de Catilina. Em ambos os casos os envolvidos, tanto os líderes quanto seus seguidores, foram executados sob a justificativa de ameaçarem o império do povo romano ${ }^{136}$. Tibério Graco foi morto em 132 a.C.; seu irmão Caio em 121 a.C. e cerca de três mil dos adeptos deste tiveram o mesmo destino ${ }^{137}$. Catilina morreu em combate em 63 a.C., mas seus seguidores foram executados nas prisões de Roma.

Foi com a criação do Principado que começou a ser formulada uma legislação própria para os crimes que, na nossa visão, poderiam ser chamados de traição, a chamada Lex iulia maiestatis, ampliada paulatinamente até abarcar, no Código de Justiniano, as ações contra a vida do imperador, de seus ministros, senadores, familiares do príncipe; a sedição dos cidadãos contra a autoridade imperial; a deserção militar e a desobediência de oficiais, dos soldados e dos magistrados das províncias romanas; o apoio aos inimigos de Roma ou a incitação à revolta dos povos aliados; as violações da imagem do imperador ou a pronúncia de palavras ofensivas ou maldições contra ele; o recurso a adivinhos para saber os negócios do Estado ${ }^{138}$.

No caso germânico havia uma sociedade bem mais simples do que a romana, mas também preocupada com as atitudes capazes de ameaçar a integridade das comunidades.

\footnotetext{
${ }^{135}$ FINLEY, Moses I. Política no mundo antigo. Lisboa: Edições 70, 1997, p. 13-19.

${ }^{136}$ As Catilinárias, de Cícero, são discursos em defesa das medidas excepcionais e duras adotadas pelo cônsul, justificadas pela necessidade de se combater um cidadão que teria se rebelado contra sua pátria e desejava destruir a cidade de Roma e seus habitantes. CÍCERO. As Catilinárias. SP: Martin Claret, $2^{\mathrm{a}}$ edição, 2006. Esta edição apresenta o texto em latim e a tradução em português.

${ }^{137}$ BLOCH, G. La République romaine. Conflits politiques et sociaux. Paris : Ernest Flammarion, 1913, p. 201-244.

${ }^{138}$ CORPUS IURIS CIVILIS. Volumen Primum. Institutiones, recognovit Paulus Krueger. Digesta, recognovit Theodorus Mommsen, retractavit Paulus Krueger. Berilini, Weidmannos, 1893. A Lei que nos interessa está no Livro XXXXVIII, Título IIII, Ad Legem Iuliam Maiestatis, p. 793-94.
} 
Aqui poderia ser incluído o apoio a um grupo ou tribo adversária, facilitando as ações destas quando lançavam ataques, e a fuga do campo de batalha (herilitz). Os germanos baseavam sua estrutura política na fidelidade à comunidade ou a um chefe. O rompimento desta fidelidade podia ser punido com a morte ou com o exílio de quem o fez. Conforme os territórios germânicos passavam por crises que ao final desencadearam as migrações para o interior do império romano a tendência foi a do crescimento dos laços pessoais de guerreiros desenraizados a um chefe capaz de conduzi-los à vitória no campo de batalha, à obtenção de um butim e ao encontro de lugares seguros onde pudessem viver.

Após a sua instalação nas diversas regiões originalmente partes do império romano, os reis germânicos passaram a organizar seus novos territórios, nos quais seu povo e os povos romanos ou romanizados deveriam coexistir. Isso os obrigou a esboçar uma administração e a organizar leis para seus súditos e alguns reinos, preocupados com a possibilidade de ações contrárias a seu monarca, fizeram uso da legislação romana, adaptando a Lex iulia maiestatis aos seus interesses e à realidade de seu meio. Neste caso, a Lex romana Wisigothorum foi uma das que mais utilizou os textos jurídicos romanos para tentar proteger seu rei ${ }^{139}$. Quanto à presença dos antigos costumes germânicos nas leis sobre a traição, há historiadores que entendem ter sido irrelevante tal contribuição, sendo quase toda a base dos códigos bárbaros extraída de uma legislação romana já influenciada pelo pensamento cristão ${ }^{140}$. De qualquer modo é perceptível que a traição não mais era vista como um atentado contra uma entidade política ou contra o representante legal desta. $\mathrm{O}$ caráter pessoal das relações hierárquicas dominava os novos reinos saídos das crises migratórias e da desagregação do império de Roma e, como consequência, a traição envolvia a quebra da fidelidade de um homem para com seu rei ou superior imediato.

Quanto ao Cristianismo, devemos lembrar que um dos eventos marcantes para o início da nova religião foi uma traição. Judas Iscariótis, um dos doze apóstolos e um daqueles seguidores mais próximos de Jesus de Nazaré, em troca de trinta moedas de prata, entregou seu mestre aos sacerdotes do Sinédrio de Jerusalém, possibilitando a sua crucificação. Embora tal acontecimento pudesse ser justificado pelas profecias referentes à vinda de um Messias, Judas foi execrado na Idade Média e passou a ser visto como uma encarnação da

139 LEAR, Floyd Seyward. Treason in Roman and Germanic Law. Houston; University of Texas Press, 1965. Especificamente sobre a Lei dos visigodos, são os artigos "Crimen Laesae Maiestatis in the Lex Romana Wisigothorum", p. 108-122, e "The public Law of the Visigothic Code”, p. 136-164.

${ }^{140}$ SARDINHA, Carlos. Alta-traição e lesa-majestade. Germanismo e romanismo na história do direito visigótico primitivo. Lisboa: Universidade Católica, 2011. 
infidelidade e da traição ${ }^{141}$. Sua ação direcionou-se a um indivíduo, Jesus, que a crença de seus seguidores entendia como ser alguém divino. Conforme o Cristianismo se fortalecia, expandia-se e, finalmente, era convertido em religião do Estado Romano, a sua concepção de todo o poder provir de Deus levava também ao entendimento de que toda contestação aos poderes constituídos era um atentado contra a ordem divina. Santo Agostinho havia sido claro quanto à necessidade do cristão submeter-se ao poder reinante, mesmo sendo este pagão. Assim a religião, em certo sentido, vinha reforçar uma legislação punitiva a atos contrários aos monarcas, pois enquanto a lei considera isso um crime, o pensamento religioso via-os como sacrilégio. A traição era assim condenada pelas leis humanas e pelas leis divinas.

No mundo franco, tanto merovíngio quanto carolíngio, embora pudesse ser usada a expressão lesa maiestatis para qualificar em textos alguns acontecimentos mostrados como contrários aos monarcas, prevalecia o entendimento de que houvera uma violação da fidelidade devida por um homem ao seu superior ${ }^{142}$. E o laço de fidelidade tivera origem em alguma forma de juramento prestado ao rei ou a um de seus condes. Mas foi apenas com os carolíngios, em especial a partir de Carlos Magno, que as promessas de fidelidade recompensadas com funções, terras ou direitos, dentro do que viria a ser a vassalidade, se tornavam uma instituição do reino franco e, depois, do novo império cristão. Tal procedimento visava tornar mais efetiva a obediência dos sujeitos ao monarca, em decorrência de uma ligação pessoal entre este e seu subordinado. E para conseguir exercer o controle de uma população dispersa em um território vasto, criado através de conquistas, foi estabelecido o dever de os homens de níveis sociais inferiores jurarem fidelidade para os representantes do poder régio, os condes ${ }^{143}$.

No caso de atos de traição, os monarcas carolíngios podiam aplicar todo o rigor na punição contra quem atentasse contra eles. Luís o Piedoso, quando da revolta de seu sobrinho Bernardo da Itália, mandou vazar os olhos deste como castigo, apesar de ambos possuírem laços de parentesco. Mas foi no próprio reinado desse imperador, após 830, que a vassalidade mostrou o seu caráter desagregador, pois muitos condes e guerreiros uniramse aos líderes rebeldes a quem tinham jurado fidelidade desconsiderando aquela devida ao seu monarca. Já os grandes potentados do império se uniram aos filhos de Luís na luta contra seu pai para obter vantagens e aumentar seus patrimônios fundiários. E quando

\footnotetext{
${ }^{141}$ DAUZAT, Pierre-Emmanuel. Judas, de l'Evangile à l'Holocauste. Paris : Perin, 2008.

${ }^{142}$ LEMOSSE, Maxime. La lese-majesté dans la monarchie franque. Revue du moyen âge latin, T-2, 1946, p. $5-24$.

${ }^{143}$ GANSHOF. Op. cit, p. 88-102.
} 
Carlos o Calvo, Luís o Germânico e Lotário lutaram entre si para definir quais seriam seus territórios a barganha com esses vassalos tornou-se ainda mais acirrada. Mas isto não impedia, ocasionalmente, demonstrações de força por parte dos monarcas, se este conseguisse julgar e punir aristocratas acusados de traição, como Carlos o Calvo fez com os dois condes da Septimânia, Bernardo de Toulouse, em 844, e o filho deste, Guilherme, em $850^{144}$.

Após 870, com a sucessão de reis politicamente inábeis e/ou desprovidos de meios para impor-se aos grandes potentados, o poder efetivo passou para as mãos desses senhores territoriais espalhados pelo reino. Eles reconheciam a existência de laços vassálicos para com o monarca, mas tinham objetivos próprios e uniam-se ao seu senhor se isso fosse de seu interesse. A luta entre os últimos carolíngios com os condes robertíngios pela posse da coroa deu mais oportunidades para esses potentados extraírem vantagens do lado ao qual apoiavam e ampliar a sua independência de fato em relação ao monarca, não importa a linhagem de onde este viesse.

Quando Hugo Capeto se tornou rei a vassalidade já havia criado uma enorme distância entre o monarca e a maioria da população de seu reino. Para atingir um indivíduo que não fosse seu vassalo, o rei deveria recorrer ao potentado local, ele sim "homem" do rei, para este apresentar o envolvido na corte régia ou aplicar a punição devida ao crime ocorrido. Era possível também a um senhor territorial, com algum interesse expansionista, alegar sua fidelidade ao monarca após tomar uma fortaleza importante para a defesa dos domínios reais, mas que até então estava sob o controle de outro vassalo. O episódio da tomada e cerco de Melun, em 991, é bem característico dessa situação. Eudes de Blois conseguira cooptar o castelão da cidade, vassalo de Bouchard, conde de Paris, para aquele permitir a sua entrada na localidade. Hugo Capeto e seu filho Roberto conduziram tropas para assediar o lugar e, após a tomada da cidade, o castelão foi enforcado, não pelos reis, mas pelo seu senhor, o conde de Paris, a quem ele tinha traído ${ }^{145}$. Eudes poderia dizer, mais tarde, ser indiferente qual o senhor que guardasse um feudo disputado, pois de qualquer forma o mesmo continuava submetido ao rei.

Era essa a situação do reino da França no século XI, quando as primeiras Canções de Gesta foram escritas. O território estava dividido entre diversos condes e duques praticamente independentes, conduzindo políticas próprias e de acordo com seus

\footnotetext{
144 ZUMTHOR, Paul. Charles le Chauve. Paris : Club Français du Livre, 1957, p. 112-118.

${ }^{145}$ BLOCH, Marc. La société féodale. Paris : Albin Michel, 1994, p. 328 ; SASSIER. Hugues Capet. p. 244245.
} 
interesses, movendo guerras uns aos outros para ampliar seus domínios. Todos se reconheciam vassalos do monarca capetíngio, embora alguns criassem artifícios para encobrir a existência desse laço. Por vezes um desses potentados acabava envolvido numa guerra contra o seu régio senhor, mas nenhum deles procurou renegar o seu laço vassálico, ou levar suas terras à secessão do reino dos francos ou romper definitivamente com o capetíngio. Não constituía traição lutar contra quem se apresentava como o poder supremo do reino e sempre havia a possibilidade de voltar às suas boas graças. E é esse tipo de situação que a epopeia francesa expõe muitas vezes em seus cantos.

No decorrer de nossa pesquisa verificamos a existência de divergências entre alguns historiadores sobre a existência do conceito de traição antes da Idade Média, se ela já estava presente nas sociedades humanas da Antiguidade ou se só no início do medievo ela tomou forma. Para F. S. Lear, a traição "É uma daquelas concepções abstratas da filosofia política que evoluem gradativamente no curso do esforço do homem para criar e desenvolver a autoridade pública" ${ }^{\text {"146 }}$. Assim, nas primeiras sociedades humanas organizadas, baseadas nos grupos familiares, o parricídio seria o mais grave e preocupante dos crimes, pois se atingisse o pater famílias abalaria o sistema de poder e comando da comunidade; se vitimasse um filho, privaria o grupo de um elemento provedor e guerreiro; se dirigido a uma mulher prejudicaria a reprodução e a continuidade da família e da linhagem. Em todos esses casos a sociedade seria afetada e ameaçada em sua existência.

Os gregos teriam as suas próprias noções de traição ligadas às obrigações dos cidadãos à Polis, aos deuses e ao conjunto de conceitos morais aceitos pela cidade como próprios de seus membros. Violar um desses itens poderia levar ao exílio ou à pena capital. Apesar disso não houve entre os gregos uma criação legal própria para os crimes contra a Polis ou contra a comunidade. Essa sistematização jurídica coube aos romanos, desembocando no crime de lesa majestade, como já vimos.

Mas contrapondo-se a essa visão ampla do crime, A. Iglesia Ferreiros defende que a traição só começou a existir de fato na Idade Média e isto era devido ao estabelecimento de relações de fidelidade entre os homens. A hierarquia do poder e das posses tornava-se pessoal, um contrato entre dois indivíduos baseado na lealdade entre um chefe e seus subordinados. Portanto, não se poderia dizer que a traição existiu no Império Romano,

${ }^{146}$ LEAR, Op. cit., p. XIII. 
pois não teria havido laços pessoais nessa sociedade, e a Lex iulia maiestatis não fora destinada a esse tipo de crime ${ }^{147}$.

Consideramos uma dificuldade para nossas pesquisas o fato de dispormos na nossa cultura das palavras já criadas para a falta estudada - traição, trair, traidor - e, quando estas são ditas, despertarem nos ouvintes um conjunto de ideias mais ou menos pré-concebido. Mas aquilo que essas palavras designam para nós tinha outros nomes em outros tempos e em outros povos. Caso disponhamos de textos antigos com referências a determinados atos contra indivíduos ou comunidades dando a entender a ocorrência de traição, eles podem usar vocábulos diferentes dos nossos e obrigar-nos a trabalhar utilizando aproximações com exemplos de nosso conhecimento. Se essa fonte foi escrita por alguém saído de uma determinada cultura, mas descrevendo os costumes de outra, a análise tornase ainda mais delicada. Esse é o caso da Germania de Tácito, um romano culto narrando os hábitos germânicos, aos quais ele opõe à decadência moral romana.

Ao analisarmos nossas fontes também encontramos dificuldades para delinear os diversos tipos de traição descritos nas Canções de Gesta. Vimos que as escolhas dos vocábulos das línguas românicas não derivaram fielmente do vocabulário clássico romano. O uso de determinados termos se expandia em alguns casos. Outros vocábulos tiveram uso muito restrito ou sequer foram utilizados pela língua vulgar. E alguns termos geram dúvidas quanto ao significado. Por esse motivo fizemos um levantamento vocabular, apresentado no capítulo seguinte, tentando definir quais deles nomeavam inequivocamente a traição nos séculos XII-XIII.

${ }^{147}$ IGLESIA FERREIROS, Aquilino. Historia de la traición. La traición regia en León y Castilla. Santiago de Compostela; Universidad de Santiago de Compostela, 1971, p. 9-19. 


\section{2 - OS TERMOS RELATIVOS À TRAIÇÃO}

A literatura medieval em vernáculo, em especial a poesia épica, apresenta vários termos designativos para a traição podendo ser estes explícitos ou uma palavra qualquer que seria entendida nesse sentido, dependendo do contexto em que aparecesse ou da situação descrita pelo poeta. Apresentaremos neste capítulo alguns vocábulos usados na nomeação do ato aqui estudado, observando em especial às palavras "traição", "traidor" e "trair", para as quais faremos uma análise mais pormenorizada. Seremos mais breves em relação aos outros termos, mas esperamos conseguir justificar, durante a exposição, a nossa escolha de certos vocábulos em detrimento de outros.

\section{1- Origem e desenvolvimentos de traïson / traïtre / trair}

\subsection{1- Tradere / traditio / traditor e os designativos latinos da traição}

As palavras "traição", "traidor" e "trair" são derivadas dos vocábulos latinos traditio, traditor e tradere, cujo significado era "entrega", "aquele que entrega" e "entregar". Elas designavam os atos de compra e venda, de troca, de passagem de um bem das mãos de uma pessoa para as de outra, o ato de dar algo para alguém, e aparecem com frequência no Codex Theodosianus ${ }^{148}$, de 438, com esse sentido.

Nos Corpus Iuri Civilis podemos encontrar tradere aplicada a um ato prejudicial à res publica dos romanos e, portanto, incluída nos artigos relativos à Lex iulia maiestatis. Mas tratava-se de nomear uma dentre as várias ações criminosas enquadradas nessa Lei, no caso a entrega de um cidadão (ou soldado romano) aos inimigos de Roma ${ }^{149}$. No mesmo parágrafo do Código encontramos outra situação para o emprego de tradere, o caso de um funcionário imperial de uma província romana recusar-se a passar (non tradidit) o comando de seu exército quando era substituído em sua função ${ }^{150}$. Era pela expressão

\footnotetext{
148 CODEX THEODOSIANUS. Disponível em http://koeblergerhard.de/Fontes/Codex Theodosianus438.htm, 2.29.2; 3.5.3; 3.5.6; 8.12.1, Interpretatio $2 ; 9.37 .4$, Interpretatio; $10.24 .3 ; 12.6 .5$.

${ }^{149}$ CORPUS IURI CIVILIS, Volumen Primo. Institutiones, recognovit Paulur Krueger; Digesta, recognovit Theodorus Mommsen. Berolini: Weidmannos, 1903, p. 794, 48.4.3: ..., qui hostem concitaverit quive civem hosti tradidetit, capitem puniri.

${ }^{150}$ Ibid., Quive, cum ei in província successum esset, exercitum successori non tradidit.
} 
crimen maiestatis que, na Roma imperial, se designava aquilo nomeado por nós como traição ao governo constituído, aos interesses do Estado ou ao representante deste ${ }^{151}$.

O sentido negativo de tradere só vem a ser adquirido quando da tradução do Novo Testamento, e dos Evangelhos sinóticos em particular, para o latim, pois esse verbo, assim como traditor e traditio, serviu para nomear o ato de Judas Iscariótes de "entregar" Jesus Cristo nas mãos de seus inimigos do Sinédrio de Jerusalém, sendo repetido diversas vezes nas Escrituras. Assim em Mateus:

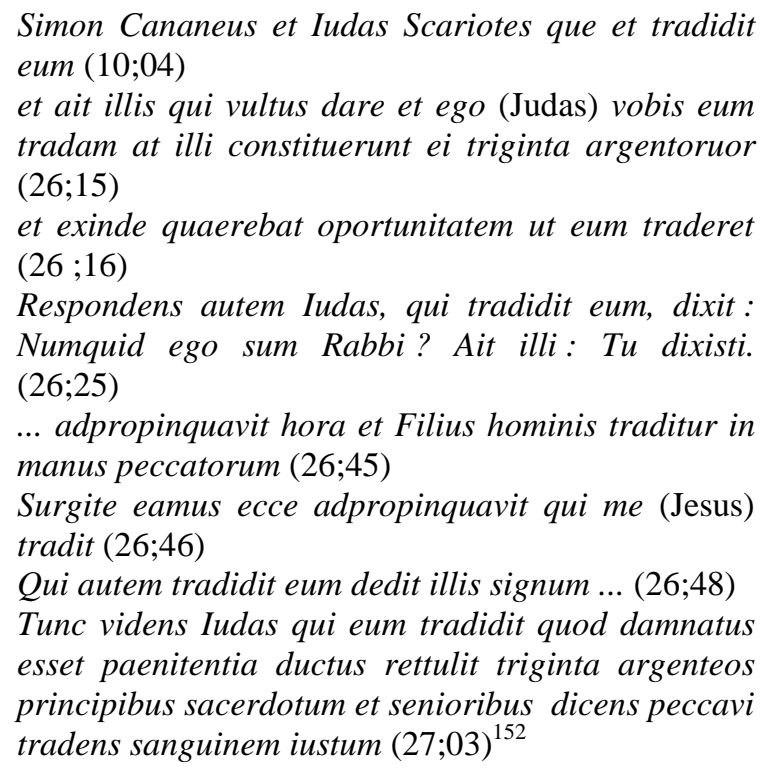

Em Marcos encontramos as seguintes menções:

... et Iudam Scarioth qui et tradidit illum $(03 ; 19)$

... sufficit venit hora ecce traditu Filius hominis in manus peccatorum $(14 ; 41)$

... surgite eamus ecce qui me tradit prope est $(14 ; 42)$

Dederat autem traditor (Judas) eius signum $(14 ; 44)$

E em João:

... amem amem dico vobis quia unus ex vobis tradet me $(13 ; 21)$

Sciebat autem et Judas qui tradebat eum $(18 ; 01)$

\footnotetext{
${ }^{151}$ CORPUS IURI CIVILIS, p. 794, 48.4.11, plane non quisque reus leges Iulia maiestatis est, in eadem condicione est, sed qui perduellionis reus est, hostili animo adversus rem publicam vel principem animatus. 152 BIBLIA SACRA IUXTA VULGATA CLEMENTINAM. Nova editio: Alberto COLUNGA O.P. et Laurentio TURRADO. Matriti: Biblioteca de Autores Cristianos, $10^{a}$ editio, 1999. BÍBLIA SAGRADA. Tradução da Vulgata pelo Pe. Matos SOARES. SP: Paulinas, 1989. Todas as citações bíblicas deste trabalho foram extraídas destas obras.
} 
... stabat autem et Indas que tradebat eum cum ipsis $(18 ; 05)$

Somente no Evangelho de Lucas encontramos o uso do adjetivo proditor aplicado a Judas quando da apresentação deste e dos outros apóstolos:

Iudam Iacobi et Iudam Scarioth qui fuit proditor. $(06 ; 16)$

Mas nos versículos seguintes o evangelista retoma os termos usado por seus companheiros:

Et abiit et locutus est cum principibus sacerdotum et magistratibus quemadmodum illum traderet eis (22;04)

et gavisi sunt et pacti sunt pecunia illi dare $(22 ; 05)$

... et quaerebat oportunitatem ut traderet illum ... $(22 ; 06)$

Iesus autem dixit ei Inda osculo Filium hominis tradis? $(22 ; 48)$

$\mathrm{Na}$ leitura dos quatro Evangelhos o verbo tradere e o adjetivo traditor ocorrem quando Judas Iscariotis é apresentado ou no conjunto de versículos nos quais sua ação contra Jesus toma forma e se concretiza. Por estar associado a uma negociação entre Judas e os membros do Sinédrio de Jerusalém, na qual o discípulo oferece seu mestre em troca de dinheiro para aqueles que desejam "comprá-lo", o ato do Iscariótis só poderia ser malvisto pelos demais apóstolos e pela comunidade formada ao redor de Jesus e de seus discípulos. Embora existam outras ocorrências de tradere / traditor / traditio nos Evangelhos apresentando o sentido de entrega, mas sem este caráter pejorativo ${ }^{153}$, a visão negativa dessas palavras, oriunda da lembrança do episódio da Paixão do Cristo e relembrada anualmente nas festas da Páscoa, tornou-se hegemônica nas doutrinas e nas mentalidades cristãs nos séculos seguintes.

Comparando o Antigo com o Novo Testamento, tradere / traditio mantém no primeiro o sentido simples de entrega conforme verificamos, por exemplo, nos Livros como o do Exxodo e dos Números, quando são feitos os discursos sobre a conquista das terras dos Cananeus ou as vitórias militares sobre os inimigos dos hebreus: Deus fala a estes sobre o destino dos cananeus, “... tradan in manibus vestris habitatores terrae, eteiiciam eos de conspectu vestro" (Exxodo, 23:31); sobre as ofertas feitas à Deus pelos fieis, "quam offerens Domino, trades manibus sacerdotis" (Levítico, 2:8); "Exaudivitque

\footnotetext{
${ }^{153}$ Como exemplos dos termos sem sentido de "traição", podemos citar: Mateus 11:27, Omnia mihi tradita sunt a Patre meo; 25:14, Sicut enim homo peregre proficiscens, vocavit servos suos, et tradidit illis bona sua. Lucas 4:17, Et traditus est illi líber Isaiae prophetae. João 19:30, Et inclinato capite tradidit spiritum.
} 
Dominus preces Israel et tradidit Chananaeum" (Números, 21:3); Deus diz a Moisés a respeito de Og, rei de Basan, “... in manu tua tradidi illum ...” (Números, 21:32); “Tradidit illos Dominus in manus Israel" (Josué, 11:8).

Também podia qualificar as consequências da desobediência do "povo eleito" aos mandamentos de seu Deus, pois como vingança divina, eram entregues às mãos de seus adversários: “... et iratus fueris eis, et tradideris hostibus et captivos duxerint eos in terram longinquam” (2 Crônicas, 6:36); “... tradidit Dominus in manibus eorum infinitam multitudinem ..." (2 Crônicas, 24:24), sobre uma derrota de Judá frente aos Sírios. Todavia esses termos não eram usados em relação às infidelidades e complôs e os episódios desta natureza descritos no Antigo Testamento, como a revolta de Absalão contra seu pai, o rei Davi, recebiam outra designação, conjuração (coniuratio) ${ }^{154}$. É o mesmo termo empregado por Cícero para a conspiração movida por Catilina ${ }^{155}$, em 63 a.C.

Quando da expansão do Cristianismo e das crises decorrentes das perseguições movidas por autoridades romanas ou por sectários das religiões pagãs ameaçadas pela nova fé, traditor reaparece como um termo injurioso adotado pelos chamados Donatistas do norte da África. Segundo os adeptos dessa visão cristã, eram impuros e excluídos da Igreja os bispos que durante a repressão do tempo de Diocleciano, em 303, entregaram os livros sagrados aos magistrados romanos para serem queimados. Esses representantes das comunidades cristãs, por adotarem esse procedimento e evitar outras punições mais duras foram denominados traditores, traidores da fé ${ }^{156}$, e em regiões de língua latina onde já estavam disponíveis os Evangelhos escritos em latim a associação com o ato de Judas Iscariótis era evidente. Os livros bíblicos seriam reverenciados pelos crentes e haveria uma identificação do texto material com a palavra de Deus, daí a violência dos rigoristas contra os acusados de vacilar durante a perseguição ${ }^{157}$. Assim como Judas fora excluído do meio dos apóstolos, quem houvesse fraquejado durante a provação quando das perseguições e não perseverara de forma intransigente na fé também deveria ser excluído da comunidade cristã. Tal entendimento não predominou na maior parte da Igreja, pois podia representar

\footnotetext{
154 No caso de Absalão, a morte deste apresenta certa proximidade com a de Judas Iscariótis, pois enquanto este se enforcava, o filho de Davi, durante a fuga após a derrota em combate, ficou preso em uma árvore pelos cabelos, pendurado entre o céu e a terra, como os enforcados. A diferença é que Joab matou Absalão com suas lanças, conf. 2 Samuel, 18:9-15. Se houve uma associação na Idade Média entre esses dois destinos, ela não fez parte dos motivos usados pelas Canções de Gesta.

${ }^{155}$ CÍCERO. As Catilinárias. SP: Martin Claret, 2006, p. 29-30, "Non vides tuam coniurationem iam teneri constrictam scientia omnium horum?"

${ }^{156}$ DANIÉLOU, Jean; MARROU, Henri: Nova história da Igreja. I- Dos primórdios a São Gregório Magno. Petrópolis: Vozes, $3^{\text {a }}$ edição, 1984, p. 256-259.

${ }^{157}$ MARKSCHIES Christoph. Estructuras del cristianismo antiguo. Madrid: Siglo Veintiuno, 2001, p. 95-96.
} 
um empecilho à difusão do cristianismo, motivo pelo qual o donatismo foi enquadrado como heresia.

O termo traditore e sua relação com Judas também pode ser observado em alguns epitáfios dos séculos VI-VII. Em sua maioria os escritos seguiriam esta forma em seu final: “... ET SI QVIS HVNC SEPVLCHRVM VI.OLAVERIT PARTE ABEAM CVM IVDA TRADITOREM ET IN DIE IVDICII NON RESVRGAT PARTEM SVAM CVM INFIDELIBVS PONAM",158. O medo de ter a sepultura violada por ladrões interessados em subtrair objetos valiosos porventura enterrados com seus falecidos donos levou estes a expressar nas lápides uma forma de maldição condenando o violador ao mesmo destino do Iscariótis. Esse tipo de frase condenatória, na qual se reserva um destino igual ou a companhia junto ao traidor de Jesus, deveria ser corrente na sociedade cristã e foi usada durante séculos, inclusive entre o pessoal da Igreja. Por exemplo, Richer de Reims, ao narrar o episódio da traição de Carlos da Lorena por Adalberon de Laon, em 991, cria um paralelo entre o jantar na noite que antecede a ação do bispo infiel com a última ceia de Jesus ${ }^{159}$. Em dado momento Carlos oferece uma taça a Adalberon e pede para ele jurar sua fidelidade ao candidato ao trono do reino franco ocidental; o clérigo jura de forma veemente - e falsa - pedindo para morrer como Judas, caso faltasse com sua promessa:

Quo (Adalberon) respondente: "Craterem recipiam
et potum libere ebibam!" K[arolus] mox prosecutus
addendum dixit: "et fidem faciam ». Ille
(Adalberon) ebibens prosecutus est: «et fidem
faciam; alioquin cum Juda interea» 160

Isso demonstra que para as mentalidades medievais Judas estava definitivamente condenado pela sua entrega de Jesus. Houve uma seita maniqueísta na qual esse personagem foi visto como o mais fiel e aquele a quem se destinou a tarefa mais difícil e necessária ao processo de salvação dos homens ${ }^{161}$, mas essa vertente religiosa já não existia no século $\mathrm{V}$ e ficou desconhecida no decorrer da Idade Média.

${ }^{158}$ CABROL, D. F.; LECLERCQ, D. H. Dictionnaire d'archéologie chrétienne et de liturgie. Paris : Letouzey et Ané, 1928, T-VIII, prémière partie, p. 273. O verbete relativo a Judas Iscariótis ocupa as páginas de 255 até 279 dessa obra.

${ }^{159}$ RICHER. Histoire de France (888-995). Éditée et traduite par Robert LATOUCHE. Paris : Les belles lettres, Tome II, 1964, p.216-219. SASSIER, Yves. Hugues Capet, p. 231-235.

${ }^{160}$ RICHER, Idem. p. 218-219. “Adalberon responde: 'Tomarei o cálice e beberei de boa vontade'. Carlos logo prossegue, incitando a juntar: 'E guardarei minha fidelidade'. Adalberon prossegue, enquanto bebe: ' $E$ guardarei minha fidelidade; caso contrário, que eu morra como Judas'." (tradução nossa).

${ }^{161}$ IRENEU DE LIÃO. Contra as heresias. SP: Paulus, 1995, p. 122, sobre os Cainitas. 
Alguns textos do século IX ligam traditio / traditor com o episódio bíblico da entrega do Cristo e o associam ao destino de determinados personagens ou ao comportamento censurável de homens cujo dever era apoiar e levar seu senhor à vitória militar. Dois poemas estudados por Claudiane Fabre servem de exemplo ${ }^{162}$. Um deles é sobre a batalha de Fontenoy (841), um escrito favorável ao imperador Lotário I na sua luta contra os seus irmãos Carlos o Calvo e Luís o Germânico, e condenava os guerreiros que o abandonaram na batalha e permitiram a derrota de seu chefe:

Ecce olim velud Judas Salvatorem tradidit, Sic te, rex, tuique duces tradiderunt gládio;

Esto cautus, ne frauderis agnus lupo previo.

O outro poema narra o assassinato do senescal Alard (878), quando este estava em seus domínios no Auxerre. É feita uma associação do seu destino com o de Jesus e mostra sua morte como um martírio, motivada pelo adultério de sua esposa de origem gascã, sendo esta censurada no ultimo verso:

Ecce Iudas uelud olim / salvatorem tradidit, Sic marit (um), sic te duc (em) / mulier mala tradidit.

Martiria innom (era) ... /...

Non est uera adcredenda / mulier uuasconia.

Em ambos os poemas os autores eclesiásticos associam claramente os atos de infidelidade, política ou conjugal, com a traição de Judas Iscariótis. Tal aproximação deveria trazer mais simpatia às vítimas, fosse este o imperador derrotado ou o senescal assassinado, pois colocados na mesma posição de Jesus quando de sua entrega, incapazes de reverter uma situação que lhes era danosa, devido à má-fé das pessoas nas quais confiaram. Esses textos também testemunham o emprego pelos cristãos ocidentais desses vocábulos oriundos da Vulgata para qualificar ainda no latim vulgar os atos de infidelidade ocorridos entre os homens.

Entretanto, os autores latinos da Antiguidade Tardia, da Alta Idade Média e mesmo da Idade Média Central não apreciavam o uso de tradere / traditio / traditor para designar os atos de infidelidade ou ações hostis contra os detentores de algum poder. Presos às

${ }^{162}$ FABRE, Claudiane. Deux planctus rythmiques em latin vulgaire du IXe siècle. In: CHANSON DE GESTE ET LE MYTHE CAROLINGIEN. Mélanges René Louis. Saint-Père-sous-Vézelay: Musée Archéologique Régional, Tome I, 1982, p. 177-252. 
formas de escrita herdadas do império romano os escritores, predominantemente ligados ao clero das catedrais e aos mosteiros, tentavam manter-se fieis aos hábitos de escrita antigos. Por conta disso empregavam as expressões proditio / proditor, insidia, infidelitas / infidus, transfuga, desertor para qualificar aquilo que denominaríamos "traição" ou quem a cometia. Obras como as de Gregório de Tours (século VI) ${ }^{163}$, Richer de Reims (século X), de Guilherme de Poitiers (século XI) ${ }^{164}$, Guibert de Nogent ${ }^{165}$ ou mesmo do abade Suger de Saint Denis (século XII) ${ }^{166}$, utilizam ocasionalmente tradere e seus derivados, entretanto, preferem empregar os termos clássicos de forma fiel ao aprendido em seus estudos, baseados na leitura dos autores da antiguidade romana.

Gregório de Tours, por pretender contar a sua história desde o tempo do Cristo, lembra que este foi "a discipulo traditur" "167, informação repetida posteriormente como “... et Filius hominis traditur ut crucificatur"168. Entretanto, quando se trata das relações humanas, Gregório segue os escritos latinos do império romano e, assim, ao referir-se ao complô contra Constantino, movido por sua esposa Fausta e seu filho Crispus diz: “... scilicet quod proditores regni eius esse voluissent" ${ }^{\text {"169 }}$. Mais adiante, narrando o julgamento de dois bispos, escreve: “... quod essent rei maiestatis et patriae proditores"170. Proditores, o termo usado na Roma imperial, continua sendo usado pelos escritores merovíngios e, também, a expressão "rei maiestatis", mas esta última com sentido diferente, pois não se refere a um atentado contra a "coisa pública" ou ao "poder detido pelo povo romano" e sim ao laço de fidelidade pessoal surgido entre um homem e um superior, no caso o rei franco, sucessor dos imperadores na Gália ${ }^{171}$.

\footnotetext{
${ }^{163}$ GRÉGOIRE DE TOURS. Histoire des Francs, Livres I-VI. Texte du manuscrit de Corbie, Bibliothèque Nationale, ms. Lat. 17665. Publié par Henri OMOUT. Paris: Alphonse Picard, 1886. GRÉGOIRE DE TOURS. Histoire des Francs, Livres VII-X. Texte du manuscrit de Corbie, Bibliothèque Naitonale, ms. Lat. 17665. Publié par Gaston COLLON. Paris: Alphonse Picard et Fils, 1893. GRÉGOIRE DE TOURS. Histoire des Francs. Traduite du latin par Robert LATOUCHE. Paris: Les Belles Lettres, 1999.

164 GUILLAUME DE POITIERS. Histoire de Guillaume le Conquerant. Éditée et traduite par Raymond FOREVILLE. Paris: Les Belles Letres, 1952.

${ }^{165}$ GUIBERT DE NOGENT. Autobiographie. Introduction, édition et traduction par Edmond-René LABANDE. Paris: Les Belles Lettres, 1981.

${ }^{166}$ SUGER. Vie de Louis VI le Gros. Éditée et traduite par Henri WAQUET. Paris : Les belles lettres, 2007.

${ }^{167}$ GRÉGOIRE DE TOURS. Liber I, Cap. XX.

${ }^{168}$ Ibid., Liber V, Cap. XIV.

${ }^{169}$ Ibid., Liber I, Cap. XXXVI.

${ }^{170}$ Ibid., Liber V, Cap. XXVII.

${ }^{171}$ LEMOSSE. Op. cit., p. 5-24.
} 
Richer de Reims sempre emprega termos herdados da tradição latina clássica para qualificar a traição e os traidores, principalmente desertor, proditor, proditio, dolus ${ }^{172}$.

Em Guilherme de Poitiers a palavra tradere é mais usada no sentido de entrega de algo a alguém, por exemplo, de terras ou da guarda de uma fortaleza: “... terras tradidit amplas ac multum opimas ..." e "traditurum interim ipsius militum custodiae castrum Doveram" ${ }^{\prime 17}$. Entretanto, aparece com sentido condenável no começo da narrativa, quando Guilherme fala da perfídia do conde Godwin que ofereceu amizade e fidelidade a Alfredo, irmão de Eduardo o Confessor, e pretendente ao trono da Inglaterra, apenas para poder entrega-lo ao seu inimigo Haroldo I, filho e sucessor de Canuto o Grande. Esse episódio assemelha-se com a paixão do Cristo, pois além da entrega há a tortura e a execução do jovem $^{174}$. Posteriormente Guilherme escreve uma espécie de profecia relativa ao crime de Godwin: "Fundis traditione tua immeritum sanguinem Normannorum: fundetur sanguis tuorum pari vice ferro Normannorum"175. Alfredo, pelo lado da mãe, era neto do duque Ricardo I da Normandia, portanto tinha sangue normando; quando Guilherme o Bastardo venceu a batalha de Hastings (1066) na qual morreu Haroldo II, filho de Godwin, consumou-se a vingança dessa antiga afronta.

Guibert de Nogent não utiliza tradere com sentido de infidelidade ou de ato contrário a alguém, preferindo especialmente o termo proditio / proditor para isso ${ }^{176}$.

Finalmente, Suger de Saint Denis segue a mesma orientação de Guibert, empregando tradere em duas oportunidades referindo-se à entrega de filhas de nobres em casamento, "nuptii tradidit"177, e nunca como qualificação de uma falta. Ele emprega proditio e proditor nos dois episódios onde ocorrem traições, a primeira ao escrever sobre o assassinato de Gui do castelo de La Roche-Guyon, morto pelo próprio cunhado, e o segundo a conspiração contra Carlos o Bom, conde de Flandres, assassinado por seus $\operatorname{vassalos}^{178}$.

\footnotetext{
${ }^{172}$ RICHER DE REIMS. Vol. I, desertor / desertoribus, p. 46, 50, 62, 82, 92, 116, 162, 172, 194, 206; proditio / proditor, p. 48, 94, 96, 140, 144, 146, 164; dolus, p. 120, 136, 202. Vol. II, transfuga, p. 20, 170 ; proditio / proditor, p. 20, 218, 248.

${ }_{173}$ GUILLAUME DE POITIERS, p. 102-105

${ }^{174}$ Ibid., p. 4-11.

${ }^{175}$ Ibid., p.10-13: «Tu derramaste através da sua traição o sangue inocente dos normandos; em retorno, será derramado o sangues dos teus pelo ferro dos normandos" (tradução nossa).

${ }^{176}$ GUIBERT DE NOGENT, para tradere, p. 222, 226, 250; para proditio / proditione, p. 268, 350, 408, 412, 418, 420, 432.

${ }^{177}$ SUGER DE SAINT DENIS, p. 36-37 e 194-195.

${ }^{178}$ Ibid., p. 112-122, para Gui de La Roche-Guyon; p. 240-250, para Carlos o Bom.
} 
Do século XII, temos uma obra interessante de Galbert de Bruges ${ }^{179}$, sobre o assassinato do conde de Flandres Carlos o Bom, em 1127. Galbert pertencia ao clero da catedral de Bruges e exerceu nela a função de notário, servindo na chancelaria ou na administração dominial do conde ${ }^{180}$, e seu escrito destinava-se a ser a história oficial do evento e até mesmo uma quase hagiografia do nobre morto. Infelizmente para Galbert outros autores conseguiram ter suas versões da conspiração aceitas pelos novos senhores de Flandres antes que a sua ficasse pronta. Escrita em latim como uma narrativa diária dos acontecimentos de 1127-1128, essa obra foi a única onde encontramos traditio / traditor / tradere dominando todo o texto como qualificativos do assassinato do senhor cometido pelos vassalos. Não se sabe exatamente qual a intenção de Galbert ao afastar-se do vocabulário latino clássico. Talvez o escrito disponível seja um rascunho para ser remanejado posteriormente e tal projeto pode ter sido abandonado pelo notário após a ascensão de Thierry da Alsácia. Também não se pode aventurar a dizer que o autor tinha maior proximidade com as palavras correntes em vulgar (traïson, traïtre) em sua cidade, pois a região de Bruges onde ele vivia era de língua germânica e não românica. Apesar disso, em uma contagem não muito exata das ocorrências, traditio tem 35 menções no texto, tradere tem 37 e traditor 62 citações. Galbert sabia da existência de outros termos para a traição, mas os utiliza parcamente: para proditor três casos, para prodire e proditio apenas um caso.

Nos textos sobre leis analisados durante o trabalho não localizamos tantas citações sobre a traição (ou a felonia) como pensávamos encontrar. No Très ancien coutumier de Normandie, tanto em latim como em francês, reconhecia-se a traditione como um dos casos em que a paz através de uma reconciliação entre o culpado e a família da vítima era difícil de ser feita ${ }^{181}$. Em compensação, na Summa de legibus Normannie in curia laicali encontramos a expressão "traditores principi" no capítulo XIII, sobre a fidelidade devida

\footnotetext{
${ }^{179}$ GALBERT DE BRUGES. Histoire du meurtre de Charles le Bon, Comte de Flandre (1127-1128), suivie de poésies latines contemporaines. Publiées par Henri PIRENNE. Paris: Alphonse Picard, 1891. GALBERT OF BRUGES. The Murder of Charles the Good. Translated and Edited by James Bruce ROSS. Toronto: University of Toronto Press, 1993.

${ }^{180}$ DHONDT, Jean. Une mentalité du douzième siècle. Galbert de Bruges. Revue du Nord, T-XXXIX, 1957, p. 101-109.

${ }^{181}$ COUTUMIERS DE NORMANDIE. Tome I: Le très ancien coutumier de Normandie, texte latin, publié par Ernest-Joseph TARDIF. Rouen: Espérance Cagniard, 1881, Capitulum XXXVI, p. 30-31. COUTUMIERS DE NORMANDIE. Tome I: Le très ancien coutumier de Normandie, textes français et Normand, publiés par Ernest-Joseph TARDIF. Rouen : A. Lestrigant ; Paris : A. Picard et Fils, 1903, Cap. XXXVI, p. 27-29.
} 
ao duque e um capítulo específico, o LXXII, intitulado "De traditione", sobre a forma de acusação e defesa orais feitas na corte ducal ${ }^{182}$.

Nos Établissements de Saint Louis, em língua vulgar, encontramos com certa frequência o termo traïson em capítulos onde são tratados os crimes puníveis com a perda da vida ou de um membro do corpo. Dos diversos crimes citados junto com a traição, neste texto, verificamos a existência de uma associação constante de traïson com murdre (assassinato) e isto representaria uma correlação entre as duas faltas no pensamento jurídico francês medieval ${ }^{183}$. Traïson era algo que podia atingir qualquer indivíduo e não apenas a um superior hierárquico.

Os Coutumes de Beauvaisis, de Felipe de Beaumanoir, apresentam varias citações do termo trä̈son, como nos Établissements, e o colocam em paralelo com murdre. Uma característica da obra de Beaumanoir decorre da vontade do autor em definir com minúcias determinados crimes e, assim, ele explica que uma trä̈son pode não estar ligada a murdre, pois ela não termina necessariamente na morte de alguém, mas murdre sempre envolveria traïson, já que se mata a outro sem dar a este oportunidade de defender-se ${ }^{184}$.

Os textos das Canções de Gesta, nos diversos dialetos nos quais se apresentam, afastam-se do vocabulário romano clássico cujo sentido poderia ser o de traição. Predominam os termos extraídos da Vulgata como designativos dos atos voltados à destruição ou ao prejuízo de determinados personagens. Possivelmente a lembrança do ato de Judas Iscariótes levou a uma redefinição de traditio tornando-a identificadora de algo condenável. Os cinco poemas por nós analisados trazem bem clara as escolhas feitas em língua vulgar para nomear o crime aqui estudado.

\subsection{2: Traïson / Traïtre / Traïr nas Canções de Gesta}

Os termos traïson, traïtre e trä̈r ocorrem com muita frequência nos poemas utilizados em nossa pesquisa para designar atos, personagens e ações condenados no decorrer das narrativas. O seu uso torna-se mais intenso na poesia épica depois de 1200 ,

\footnotetext{
${ }^{182}$ COUTUMIERS DE NORMANDIE. Tome II: La Summa de legibus Normannie in curia laicali. Textes critiques publiés par Ernest-Joseph TARDIF. Rouen: A. Lestringant ; Paris : A. Picard et Fils, 1896, p. 38-39 e 181-182.

${ }^{183}$ ÉTABLISSEMENTS DE SAINT LOUIS (Les). Publiées par Paul VIOLET. Paris : Renouard, Tome II, 1886, p. 14,47, 49, 144, 187, 190, 314, 343, 357, 407, 447, 458.

${ }^{184}$ PHILIPPE DE BEAUMANOIR. Coutumes de Beauvaisis. Texte critique publié par Am. SALMON. Paris: T-I, Alphonse Picard et Fils, 1899, p. 428-430.
} 
como pudemos observar após a contagem de suas ocorrências e quando são empregados. Quanto aos personagens que estão a elas ligados como autores, consideramos mais prático organizar quadros para cada Canção de modo a verificar quem era mais propenso a ser acusado desse ato. E, no final deste subcapítulo, poderemos observar como a traição e os traidores vão se tornando cada vez mais dominantes nos enredos dos poemas.

Na Chanson de Roland, do manuscrito de Oxford, essas palavras aparecem 22 vezes, assim distribuídas: traïson, 13 vezes; traïtre, 03 vezes; traïr, 06 vezes.

Quadro n 01: Distribuição de Traïson-traïtre-traïr na Chanson de Roland

\begin{tabular}{|l|c|c|c|c|}
\hline & Traïson & Traïtre & Trä̈r & Total \\
\hline Ganelon & 10 & 01 & 03 & 14 \\
\hline Carlos Magno & 01 & - & 01 & 02 \\
\hline Pagãos & 02 & 02 & - & 04 \\
\hline Adágio & - & - & 02 & 02 \\
\hline
\end{tabular}

Pelo Quadro $\mathrm{n}^{\mathbf{0}} 01$ acima, é perceptível que esses termos são utilizados predominantemente em relação a Ganelon (14 ocorrências) devido ao papel deste personagem no desastre de Roncesvales cantado no poema. Com a sua utilização frequente procurou-se deixar bem claro aos ouvintes ou ao leitor o caráter negativo de Ganelon, assim como sua culpa e responsabilidade na morte dos doze pares da França e no prejuízo causado ao seu senhor Carlos Magno. Desde a primeira menção do personagem houve esse direcionamento, quando o imperador chamou seus conselheiros para discutir a proposta de paz do sarraceno Marsílio:

\footnotetext{
Li empereres s'en vait desuz um pin, ses baruns mandet pur sun cunseill fenir: le duc Oger, l'arcevesque Turpin, Richard li velz e sun nevuld Henri, e de Gascuigne li proz quens Acelin, Tedbald de Reins e Milun, sun cusin, e si i furent e Gerers e Gerin ; ensembl'od els li quens Rollant $i$ vint e Oliver, li proz e li gentilz. Des Francs de France en $i$ ad plus de mil. Guenes $i$ vint, ki la traïsun fist.
}

Nesse episódio há dois pontos a diferenciar Ganelon dos demais barões de Carlos. O primeiro é que o seu nome não foi colocado sequencialmente com o dos demais 
conselheiros. Entre eles o verso "Des Francs de France en i ad plus de mil" separa o traidor daqueles cuja fidelidade ao seu senhor é inquestionável. O outro ponto é o paralelo claríssimo com os textos dos quatro Evangelhos quando citam pela primeira vez o nome de Judas, como em Mateus:

Et convocatis duodecim discipulis suis, dedit illis potestatem spirituum immundorum, ut eiicerent eos, et curarent omne languorem, et omnem infirmitatem. Duodecim autem Apostolorum nomina sunt haec. Primus: Simon, qui dicitur Petrus, et Andreas frater eius, Iacobus Zebedaei, et Ioannes frater eius, Philippus, et Bartholomaeus, Thomas, et Matthaeus publicanus, Iacobus Alphaei, et Thaddaeus, Simon Chananeus, et Iudas Iscariotes, qui et tradidit eum.

(Mt, 10:1-4)

Décimo segundo nome citado no grupo de conselheiros convocado pelo imperador para discutir um assunto capital, assim como Judas quando chamado por Jesus para receber o poder de curar os homens, Ganelon seria um personagem pelo qual o público do poema nutriria hostilidade imediata. Some-se o fato da antecipação literária dos atos condenáveis nos dois textos, "ki la traïsun fist" e "qui et tradidit eum", e não haveria salvação para o padrasto de Rolando, assim como não houve para o Iscariótis.

De forma surpreendente aparece o nome de Carlos Magno ligado à traição, mas tratava-se não de uma acusação e sim de uma provocação, lançada pelo sobrinho de Marsílio pouco antes do choque entre as forças sarracenas e cristãs em Roncesvales. O pagão dissera aos doze pares "Traït vos ad ki a guarder vos out" (v. 1192), dando a entender que o imperador, a quem caberia proteger aqueles homens, havia-os traído por deixá-los expostos na retaguarda da hoste. Rolando mata o atrevido e nega a falta de seu senhor dizendo que este "ne traïsun unkes amer ne volt" (v.1208).

Há acusações contra os pagãos utilizando-se os termos traïsun e traïtre, mas somente em relação à Marsílio, por ter mandado decapitar os mensageiros cristãos Basan e Basílio, há uma justificativa para seu emprego. Nos outros casos tratou-se mais de um procedimento narrativo visando denegrir determinados personagens de modo a mostrá-los tão maus a ponto do único destino possível para eles ser a morte pelas armas cristãs.

Como adágio há duas ocorrências seguidas, posteriores à execução dos parentes de Ganelon e dele próprio. Era uma forma de acentuar no discurso poético a impossibilidade de uma traição ficar impune e seu responsável trazer desgraça não apenas para si, mas 
também para sua linhagem, algo importante de ser pensado em uma sociedade onde os laços familiares extensos permaneciam vigentes (v. 3959 e 3974).

Girart de Vienne é o poema que menos apresenta os termos aqui estudados, 22 citações. Contamos 08 menções de traïson, 09 de traïtre e 05 do verbo traïr.

Quadro 02: Distribuição de Traïson-traïtre-traïr no Girat de Vienne

\begin{tabular}{|l|c|c|c|c|}
\hline & Traïson & Traïtre & Trä̈r & Total \\
\hline Ganelon & - & - & 01 & 01 \\
\hline Ganelidas & 02 & - & - & 02 \\
\hline Franceses & 02 & 05 & 01 & 08 \\
\hline Homens de Girart & 02 & 04 & 01 & 01 \\
\hline Judas & - & - & - & 02 \\
\hline Sem identificação & 02 & - & 02 \\
\hline
\end{tabular}

O primeiro personagem a ser citado em nossos quadros será sempre Ganelon, pois ele se tornou um paradigma da traição épica e mesmo quando um poema não trata diretamente dele e de suas ações ao menos há a lembrança de seu crime. É o caso na Canção Girart de Vienne, onde seu nome é citado apenas para lembrar sua responsabilidade no desastre de Roncesvales (v. 1185 e 6925).

Quanto ao termo "Ganelidas", nesta Canção ele seria até impróprio, pois a linhagem não realiza nenhuma ação no transcorrer da narrativa. Mesmo os atritos na corte são de iniciativa de outras linhagens, invejosas daquela de Garin de Monglane e de Girart. Na verdade ocorre uma censura à "gesta de Doon de Mayence", a segunda mencionada por Bertrand de Bar-sur-Aube, e que apesar de rica e composta de cavaleiros de coragem, devido ao seu orgulho e ganância, é responsável pelos males do reino. E Ganelon é incluído nessa família como o caso extremo da maldade dela:

Des rois de France est la plus seignorie, et l'autre aprés, bien est droiz que jeu die, fu de Doon a la barbe florie, cil de Maience qui molt ot baronnie. El sien lingnaje ot gent fiere et hardie ; de tote France eüsent seignorie, et de richece et de chevalerie, se il ne fusent plain d'orgueil et d'envie. De ce lingnaje, ou tant ot de boidie, fu Ganelon, qui par sa tricherie, en grant dolor mist France la garnie, qant en Espangne fist la grant felonnie dont furent mort entre gent paiennie 
Os versos iniciais do poema Girart de Vienne, na versão de Bertrand, criam ou manifestam de forma escrita, pela primeira vez, a divisão da épica francesa por Ciclos: o do rei, o de Doon de Mayence e o de Garin de Monglane. Entretanto, sua preocupação principal é a de unir seu herói à família de Guilherme de Orange, modelo de fidelidade vassálica do lendário carolíngio, daí o autor não atentar muito para a "lingnage, ou tant ot de boidie"185.

O emprego contra os franceses e os homens de Girart não correspondem à efetiva acusação de um crime. Neste poema os termos funcionam como ofensas lançadas a um adversário para provoca-lo. O autor deste remanejamento tentava mostrar seu herói como um cavaleiro e vassalo exemplar, levado à guerra por uma injustiça régia. Não caberia no enredo a ocorrência de uma traição, especialmente porque a linhagem ganelida ainda não tinha tomado forma quando Bertrand concluiu seu trabalho e houve apenas um esforço para situar a origem de Ganelon dentro das diversas parentelas francas.

Com a Gesta Renaut de Montauban há um aumento acentuado de ocorrências dos termos estudados, no total de 176. Isso se deve não apenas à extensão da Canção, com 14.310 versos, como ainda pela presença de episódios onde o poeta desenvolveu situações detalhadas de traição. Traïson aparece 48 vezes, traïtre 97 vezes e traïr 31 vezes. Desta vez observamos uma concentração desses vocábulos em determinados episódios e, principalmente, em certos personagens, conforme se depreende da observação dos dados abaixo.

Quadro 03: Distribuição de Traïson-traïtre-traïr no Renaut de Montauban

\begin{tabular}{|l|c|c|c|c|}
\hline & Traïson & Traïtre & Trä̈r & Total \\
\hline Ganelon & 01 & - & - & 01 \\
\hline Ganelidas & 02 & 33 & 01 & 08 \\
\hline Herves de Lausane & - & 06 & - & 06 \\
\hline Ripeu & 01 & 05 & - & 09 \\
\hline Yon da Gasconha & 14 & 05 & & 08 \\
\hline Conselheiros de & 05 & 03 & - & 06 \\
\hline Yon & & 02 & - & 08 \\
\hline Carlos Magno & 04 & &
\end{tabular}

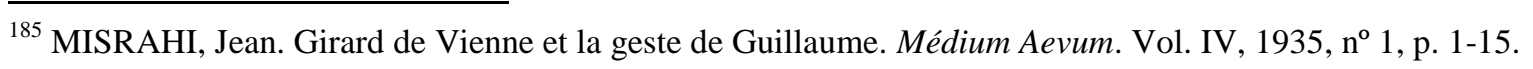




\begin{tabular}{|c|c|c|c|c|}
\hline Franceses & 05 & 11 & 02 & 18 \\
\hline Ogier & 04 & 05 & 04 & 13 \\
\hline Reinaldo & 05 & 05 & 03 & 13 \\
\hline Maugis & 02 & 10 & 01 & 13 \\
\hline $\begin{array}{l}\text { Bueves de } \\
\text { Aygremont }\end{array}$ & 01 & 04 & - & 05 \\
\hline Aymonidas & 02 & 06 & - & 08 \\
\hline Maria Madalena & 01 & - & - & 01 \\
\hline Judas & - & 01 & 03 & 04 \\
\hline $\begin{array}{l}\text { Pedreiros de } \\
\text { Colônia }\end{array}$ & - & 01 & - & 01 \\
\hline Sapateiro de Paris & - & - & 01 & 01 \\
\hline Emboscada & 01 & - & 02 & 03 \\
\hline Adágio & - & - & 03 & 03 \\
\hline
\end{tabular}

O nome de Ganelon como faltoso aparece uma vez e, curiosamente, numa incongruência do poema. Lotário, filho do imperador, ameaçou Bueves de Aygremont, um vassalo relapso, e os versos finais do seu discurso são: "Et lors seras jugiez come fu Guenelon / Qui fist la traïson de Rollant le Baron" (v. 598-99). Rolando vai reaparecer no verso 4647 ainda para ser armado cavaleiro e Ganelon está ativo com seus parentes desde o verso $1080^{186}$.

É justamente à linhagem ganelida que mais é relacionada com os termos estudados, especialmente com o adjetivo traïtre. Isso ocorre não porque estivessem conspirando contra o monarca, mas sim por apresentarem-se como os executores dos mais condenáveis planos de Carlos Magno, primeiro contra Bueves e, depois, contra os quatro filhos de Aymon de Dordogne. Os Ganelidas procuram obter poder e riqueza através de uma obediência interesseira ao imperador, assumindo o papel épico dos maus conselheiros pois a continuidade da guerra os faz indispensáveis enquanto os bons conselheiros, favoráveis à paz, não eram ouvidos pelo rei.

Dois personagens individualizados também são muito qualificados pelos termos aqui estudados e, também, muito apodados de traïtres: Herves de Lausanne e Ripeu de Ripemont. O primeiro usou da mentira e da dissimulação para ser aceito na inexpugnável fortaleza de Montessor e, assim, matar Reinaldo e seus irmãos (v. 2815-3012). Não é

\footnotetext{
${ }^{186}$ Esta não é a única incongruência do poema, quer seja na versão do manuscrito Douce ou na do manuscrito La Vallière, o que nos leva a pensar ter havido um agrupamento de diversas narrativas independentes dos heróis Aymonidas para criar a história contínua de Reinaldo de Montauban hoje conhecida.
} 
mencionada no poema a linhagem da qual ele era originário. Quanto a Ripeu, uma menção ao nome de seu pai como Fouque, morto pelo herói, faz pensar em Fouque de Morillon, um ganelida (v. 9565- 69), mas não há outras menções a esta linhagem em seu episódio, motivo pelo qual o mantivemos separado dela. Este personagem foi chamado de traidor por concordar em conduzir o enforcamento de Ricardinho, o mais novo dos Aymonidas. Essa determinação de Carlos Magno não fora aceita por nenhum dos doze pares ou pelos principais cavaleiros da corte, pois todos eles consideravam desonrosa a sua execução. Por ter concordado em fazer tal serviço Ripeu perdeu a dignidade e o poeta passou a identificalo com o pior adjetivo da narrativa.

Outro personagem associado aos termos traïson, traïtre e traïr é o rei Yon da Gasconha, o senhor direto de Reinaldo e, também, o seu genro. Por aceitar encaminhá-los à emboscada em Vaucoulours e mentir quanto às intenções do imperador, Yon viu sua honra destruída. Entretanto, são muitos os versos nos quais ele mesmo se acusa do malfeito, remoendo um grande remorso, o que talvez tenha levado o poeta a poupar-lhe a vida no poema, muito embora o culpado tenha "morrido para o mundo" ao entrar em um mosteiro para pagar seu pecado e, com isso, privando definitivamente a Gasconha de reis: "Puis n'out roi em Gascoigne par cele traïson" (v. 8338).

Parte da culpa do rei gascão é lançada sobre seus conselheiros, os responsáveis pela decisão de seu senhor em apoiar os maus desígnios do imperador franco. Movidos pela inveja contra os Aymonidas, vistos como estrangeiros que fizeram fortuna servindo Yon e apoiando este contra os vassalos indóceis de seus domínios, os cortesãos ameaçaram unirse aos franceses contra seu rei. De certo modo estes conselheiros, em especial o bispo ou conde de Avignon, reduzem um pouco a responsabilidade de Yon na traição de Vaucoulours, mas ao mesmo tempo acentuam a diferença deste personagem em relação a Carlos. Enquanto este é censurado por não ouvir seus melhores auxiliares, o gascão aparece como um monarca incapaz de tomar por si próprio uma decisão e preferir seguir o parecer dos outros, mesmo sendo ele injusto.

Carlos Magno, monarca modelo em muitas Canções, não foi isentado da acusação de traição no poema Renaut de Montauban. Especialmente no prólogo "Bueves de Aygremont", no qual violando uma promessa feita de permitir que Bueves se justificasse na corte de Paris e fizesse uma compensação por ter morto Lotário, o imperador concorda em mandar os Ganelidas emboscarem e assassinarem o barão de Aygremont. Apesar disso, não há punição para Carlos e a vingança dos parentes de Bueves termina na derrota destes em batalha. 
Há acusações genéricas contra os franceses, especialmente por participarem dos atos contrários aos Aymonidas. Mas sobre Ogier o Dinamarquês o poeta criou uma situação complexa, pois ele é parente de Reinaldo e vassalo de Carlos. Por conta disso Ogier oscila em sua fidelidade e no caso dele tomar posição em favor de um dos dois beligerantes estaria incorrendo em traição perante o outro contendor.

Com relação aos adversários do imperador, Reinaldo é visto como traidor por lutar contra seu senhor e, principalmente, por ter morto o sobrinho deste, Bertolai, durante uma festa na corte real. Maugis também é assim apodado diversas vezes, mas isso não decorre dele ter movido algum complô contra o monarca e sim por deter habilidades mágicas e agir como ladrão, tornando-o praticamente invencível. Mais grave é a posição de seu pai, Bueves de Aygremont, responsável por duas faltas graves perante seu imperial senhor. Primeiro ele não compareceu à hoste convocada para combater os pagãos da Saxônia e, depois, o assassinou o filho do rei que lhe fora enviado como mensageiro. Embora o poeta elogie Bueves frequentemente, este, ao contrário de outros "rebeldes", não conhece o perdão régio e nem permanece vivo no final do poema.

Judas Iscariótis é lembrado no texto por ter traído Jesus, especialmente nas chamadas "orações diante do grande perigo" proferido pelos heróis nos momentos mais difíceis da história, no qual se pede ajuda divina através da lembrança dos eventos bíblicos. Interessante é a citação do nome de Maria Madalena como mulher plena de traição, mas quem pronunciara a frase foi Judas, logo, não passava de uma calúnia.

Alguns representantes do meio urbano são citados no decorrer da narrativa por agirem contra Reinaldo, no caso, o sapateiro de Paris que tentou denunciar a presença do barão e de seu primo Maugis quando da corrida de cavalos promovida pelo imperador, e os pedreiros de Colônia que, por inveja, assassinaram o herói e tentaram esconder o seu cadáver.

Embora não seja comum denominar uma situação com esse termo, traïson é usada uma vez para nomear uma emboscada. E por três vezes o verbo trä̈r aparece em adágios citados no poema.

A Canção de Gesta Gaydon supera todos os outros poemas analisados no quantitativo das palavras aqui estudadas, perfazendo nada menos do que 303 ocorrências, assim distribuídas: traïson, 71 vezes; traïtre, 218 vezes, traïr, 14 vezes. Há uma concentração acentuada desses vocábulos para designar os membros da linhagem de Ganelon e as ações perpetradas ou planejadas por eles. 
Quadro 04: Distribuição de Traïson-traïtre-traïr no Gaydon

\begin{tabular}{|l|c|c|c|c|}
\hline & Traïson & Trä̈tre & Trä̈r & Total \\
\hline Ganelon & 04 & 02 & 06 & 12 \\
\hline Ganelidas & 41 & 208 & 06 & 01 \\
\hline Gaydon & 16 & 02 & 01 & 09 \\
\hline Ferraut & 06 & 02 & - & 01 \\
\hline Gautier & 01 & - & - & 02 \\
\hline Angevinos & 01 & - & - & 04 \\
\hline Adágio & 02 & - & - & - \\
\hline Sem difinição & - & &
\end{tabular}

Embora a narrativa evoque um tempo posterior à morte de Ganelon este é muito citado, pois a história se refere a Thierry, o jovem cavaleiro responsável pela derrota de Pinabel no duelo judicial e por comprovar ter havido uma traição. O fato de Carlos Magno se esquecer disto e apoiar-se no clã ganelida obriga o herói a lembra-lo constantemente desse serviço.

Quanto à linhagem ganelida, o fato dos termos serem usados contra eles 255 vezes, 208 delas sob a forma do adjetivo trä̈tre, demonstra claramente o direcionamento dado pelo poeta para o julgamento destes personagens pelo seu público. Não se tratava apenas de mostrar a família de Ganelon como fonte de toda a maldade épica, pois ao fazê-los recorrer a procedimentos indignos dos integrantes da cavalaria, como o envenenamento dos adversários (e até dos próprios parentes), havia um esforço poético para demonizá-la. Missas com rituais inversos aos aceitos pela Igreja e seus fiéis, a presença de demônios a protegê-los no lugar dos anjos e sua capacidade de seduzir o imperador como se o enfeitiçassem, faziam da linhagem algo pior do que os maus conselheiros de Yon da Gasconha. Como são muitos os personagens citados como membros do clã (como Thibaut d'Aspremont, Aulori, Hertaut, Gui d'Autefoille), mas todos mantendo as mesmas características traiçoeiras, nós não vimos motivo para individualiza-los.

Gaydon é acusado de traição em várias oportunidades, mas ou são os Ganelidas os acusadores ou é um imperador ludibriado e pouco propenso a buscar a verdade quem faz essas acusações. Por tratar-se de um atentado ocorrido contra o rei, utilizando-se um procedimento odioso, o envenenamento, trä̈son tem o seu caráter negativo acentuado. Mas isso torna ainda mais gritante a injustiça de Carlos para com o seu fiel campeão angevino. O mesmo ocorre com o sobrinho de Gaydon, Ferraut, responsável pela morte de 
vários inimigos, mas todas justificadas por ações hostis movidas pela família de Ganelon. Aliás, é esta a responsável pelas acusações perante o rei e este não se dá ao trabalho de ouvir o acusado para tomar partido do pérfido clã. As citações contra os cavaleiros angevinos ou contra o bravo Gautier também não tem fundamento, pois lançadas pela má linhagem.

Há ainda duas ocorrências de traïson sob a forma de adágios e quatro ocorrências as quais encontramos dúvidas quanto ao enquadramento e a quem diziam respeito efetivamente.

Para o poema Jehan de Lançon temos o sério problema do manuscrito do século XIII estar mutilado de talvez 1.900 versos do seu início. Ficamos reduzidos à análise dos 4.146 versos restantes, que vão da fuga de Basin do acampamento de Jehan de Lançon até a captura deste pelo imperador e pelo mágico ladrão. Pudemos contar para traïson 13 ocorrências, para traïtre, 38; para traïr, 06; e para uma variante, trä̈sement, 01 ocorrência. Isso totalizou 58 citações. Não é possível saber exatamente quantos versos perdidos utilizaram esses termos, mesmo empregando a versão do século XV desse poema, dadas as acentuadas diferenças ortográficas e inclusões feitas no texto mais recente.

Quadro 05: Distribuição de Traïson-traïtre-traïr no Jehan de Lançon

\begin{tabular}{|l|c|c|c|c|c|}
\hline & Traïson & Traïtre & Trä̈r & Traïsement & Total \\
\hline Ganelon & 03 & 12 & 02 & 01 & 18 \\
\hline Ganelidas & 06 & 15 & 01 & - & - \\
\hline Jehan & 01 & 03 & - & - & 04 \\
\hline Malaquin & - & 01 & - & - & 01 \\
\hline Homens de & - & - & 01 & - & 01 \\
\hline Jehan & - & 01 & - & - & 02 \\
\hline Isoré & - & 02 & - & - & 01 \\
\hline Carlos Magno & 01 & 04 & 02 & - & 01 \\
\hline Basin & 01 & - & - & - & - \\
\hline Thierry & 01 & - & - & - & - \\
\hline Servein & & & & - & - \\
\hline
\end{tabular}

Ganelon está bem representado nas ocorrências dos termos estudados, algo nada excepcional em um poema cuja narrativa se coloca antes de Roncesvales, mas já prevê o papel nefasto deste personagem. O trabalho principal deste poema é a integração de 
Ganelon com sua linhagem mostrada como tendo o mesmo caráter de seu patrono, não apenas interessada em prejudicar os interesses de Carlos Magno, mas cogitando até destrona-lo. Assim, os Ganelidas frequentadores da corte em Paris também são citados muitas vezes como traïtres e seus atos como traïson.

Jehan de Lançon, seu mágico Malaquim e seus homens estão pouco relacionados com os termos, embora Jehan empregue frequentemente procedimentos censuráveis, baseados na mentira, na demonstração de uma falsa amizade ou respeito, para tentar vencer os doze pares da França. O cavaleiro que lhe foi infiel e aliou-se a Rolando, Isoré, recebe apenas uma designação como traïtre.

Do lado imperial, Carlos é adjetivado duas vezes, mas tratava-se da ação de um Ganelida interessado em enganar alguns cavaleiros para estes se unirem ao senhor de Lançon. Basin também é acusado várias vezes, mas, tal como Maugis no Renaut de Montauban, eram acusações lançadas por seus inimigos, incapazes de vencer um indivíduo expert em magia e no furto. Uma vez é lançada contra Thierry, negando ser este capaz de cometer uma traição.

Quanto ao ladrão Servein, sua tentativa de enganar Basin para mata-lo garantiu-lhe ao menos uma acusação desse crime.

Desses diversos quadros podemos extrair algumas conclusões gerais que nortearão outros desenvolvimentos desta pesquisa. Em primeiro lugar é o papel de Ganelon como "o Judas" das Canções de Gesta. Presente ou nomeado em todas elas, seu nome está diretamente ligado à traição. Com o passar do tempo seu caráter vai sendo mais desabonado a ponto do ato impulsivo descrito na Chanson de Roland tornar-se parte da personalidade de Ganelon, no Jehan de Lançon. Se no primeiro poema ele teria sido motivado pela sua designação para a embaixada junto a Marsílio, no último poema a predisposição para a traição já existia nele antes da expedição à Espanha.

Quanto à linhagem ganelida, esta não tem características condenáveis no Roland, onde não há nenhuma acusação contra ela e esta se perde por levar às últimas consequências o seu dever de defesa de um de seus membros. Paulatinamente ela vai sendo transformada literariamente para tornar-se a origem de todos os personagens traidores responsáveis pelas crises no império franco, colocando mesmo Ganelon em segundo plano, como no Renaut de Montauban, e fazendo do caráter traiçoeiro um vício ligado ao sangue de seus membros, tal como aparece no Gaydon. 
Os reis, mesmo Carlos Magno, não estão livres de serem acusados de traição ou de agirem como traidores. Tais alegações podem ser injustificadas ou, se justificadas, decorrem do abuso do poder pelo monarca carolíngio épico e, para Yon da Gasconha, de sua fraqueza diante das ameaças de conselheiros invejosos.

Lançados contra diversos personagens, alguns deles totalmente inocentes de tal crime, esses termos parecem infundir nas mentalidades dos homens medievais, em especial sua elite cavaleiresca, um horror à traição representada como o pior crime a ser cometido e do qual foi vítima o próprio fundador do Cristianismo.

Mas traïtre, traïson, traïr não são os únicos designativos. Há outras palavras que podem tomar esse sentido, entretanto só a análise de suas ocorrências nos textos permite a confirmação desse entendimento.

\section{2: Felonie / Felon nas Canções de Gesta}

Os termos Felonie e felon, pelos estudos até agora realizados, não têm uma origem definida $^{187}$. Eles poderiam estar ligados aos termos latinos fell-, fel, denominando a bílis e com o significado de amargor ou veneno, havendo uma associação nas mentalidades antigas entre a bilis e o veneno ${ }^{188}$. Esses vocábulos teriam sido utilizados como sinônimo de infidelidade ou traição em 858 quando o arcebispo Hincmar de Reims escreveu uma missiva para o rei da Francia Orientalis, Luís o Germânico, censurando-o por invadir as terras de seu irmão Carlos o Calvo na Francia Occidentalis. A palavra latinizada fellones era empregada para designar os grandes do reino ocidental que passaram para o lado de Luís devido ao seu sucesso inicial na invasão e, segundo o arcebispo, estes indivíduos o abandonariam no caso da fortuna deixar-lhe de sorrir ${ }^{189}$.

Costuma-se considerar felon / felonie como os termos próprios para designar a infidelidade feudal, a quebra dos laços vassálicos e como sinônimo de traição ${ }^{190}$. Esse entendimento parece bem arraigado e é corroborado pelas obras que tratam do feudalismo

\footnotetext{
${ }^{187}$ HOLLYMAN, K.-J. Le développement du vocabulaire féodal pendant le haut Moyen Age. Genève : Droz ; Paris : Minard, 1957, p. 151.

${ }^{188}$ POLLOCK, F.; MAITLAND, F. W. Op. cit., Vol. II, p. 464-465.

${ }^{189}$ BOUREAU, Alain. De la félonie à la haute trahison. In. Le genre humain, 16-17: La trahison. Paris : Seuil, 1988, p. 268-269; HALPHEN. Op. cit., p. 311-317.

${ }^{190}$ LITTRÉ, Émile. Dictionnaire de la langue française. Paris: Gallimard; Hachette, T-3, 1958. Neste dicionário encontramos no verbete félon, onne esta definição: traidor ou rebelde; diz-se do vassalo que agia contra a fé devida ao seu senhor. Por extensão, traidor ou malvado.
} 
e das relações vassálicas, como as de F.-L. Ganshof e de R. Boutruche ${ }^{191}$. Entretanto, nas leituras feitas nas obras em latim de Richer de Reims, de Guilherme de Poitiers, de Suger, de Galbert de Bruges e de Guibert de Nogent não encontramos empregada uma única vez o vocábulo Fello(nem), quer fosse apenas para desdenhar alguém ou como uma acusação de infidelidade ou traição ${ }^{192}$. Mas no Très ancien coutumier de Normandie, o capítulo XXXV, Des Omecides, ao tratar da morte de alguém pelas mãos de um parente (pai, mãe, filho, filha, primo) é usada a expressão "par felonie" em oposição a "par mesaventure"193. $\mathrm{O}$ editor E.-J. Tardif traduziu felonie por "trahison, préméditation"194. No caso estabelecia-se a diferença na punição de quem matara um familiar sem intenção, por acidente, daquele que planejara a morte do parente sendo o castigo para este último a morte.

Os dicionários especializados no francês antigo têm outras definições para felon / felonie: terrível, cruel, crueldade, malvado, maldade, violento, violência, duro, furioso, difícil, impiedoso, assustador, ameaçador e estes podiam ser aplicados tanto a coisas como a pessoas ${ }^{195}$. Verificar qual o significado que essas palavras tomavam nas Canções de Gesta pode indicar como, de fato, elas eram entendidas pelo público dos poemas.

As ocorrências desses termos na Chanson de Roland são: 03 para felonie e 32 para felon/fel:

Quadro 06: Distribuição de Felonie-felon/fel na Chanson de Roland

\begin{tabular}{|l|c|c|c|}
\hline & Felonie & Felon/fel & Total \\
\hline Ganelon & 01 & 09 & 10 \\
\hline Pagãos & 02 & 16 & 18 \\
\hline Franceses & - & 07 & 07 \\
\hline
\end{tabular}

Ganelon recebe principalmente o qualificativo felon/fel em várias ocasiões, algumas delas acompanhadas de traïr e seus derivados. Todavia é questionável que o termo fosse considerado como sinônimo de traïtre, servindo mais para rebaixar moralmente o

${ }^{191}$ BOUTRUCHE, Robert. Seigneurie et féodalité, T-II: L’apogée (XIe-XIIIe siècles). Paris: Aubier, 1970, p. 210-211; GANSHOF, F.-L. Op. cit., p. 158.

${ }^{192}$ GALBERT DE BRUGES. Histoire du meurtre de Charles le Bom. GREGOIRE DE TOURS. Histoire des Francs; GUIBERT DE NOGENT. Autobiographie; GUILLAUME DE POITIERS. Histoire de Gullaume le Conquerant ; RICHER. Histoire de France ; SUGER. Vie de Louis VI le Gros.

${ }^{193}$ COUTUMIERS DE NORMANDIE, T-I, 2e partie, p. 26-27.

${ }^{194}$ Ibid., p. 110. Podemos aproximar esta expressão também ao murdre.

${ }^{195}$ GODEFROY, Frédéric. Dictionnaire de l'ancienne langue française et de tous sés dialectes du IXe au XVe siècle. Paris : Librairie des sciences et des arts, T-III, 1938, p. 743-746. 
personagem por este não ter tido o comportamento de um cavaleiro cristão ${ }^{196}$. Mesmo na acusação lançada por Thierry contra Ganelon, na corte de Carlos Magno, não fíca demonstrado ser felonie a designação do seu crime contra o imperador, seu senhor vassálico:

Que que Rollant Guenelun forsfesist,

Vostre servise l'en doüst bien guarir.

Guenes est fels d'iço qu'il le trä̈t,

Vers vos s'en est parjurez e malmis.

Pur ço le juz a pendre e a murir,

E sun cors metre en peine e en exil

Si cume fel ki felonie fist.

Em relação ao rei houve a acusação de perjúrio. Quanto ao verso 3830, “Guenes est fels d'iço qu'il le traït", refere-se ao ato contra Rolando, seu enteado. O crime está definido na expressão "le traït" e a parte inicial do verso "Guenes est fels" parece indicar a degradação moral do acusado por ter cometido algo infame.

Os sarracenos recebem esses designativos em 18 oportunidades, portanto a metade das ocorrências foi dirigida contra eles. Dizer, como escreveu A. Dessau ${ }^{197}$, serem eles felons por traírem ao verdadeiro Deus, que a Chansond de Roland defende ser o dos cristãos, não nos parece correto, pois os pagãos não são representados como apóstatas e sim como seguidores de outra crença oposta ao Cristianismo e sua inimiga. Novamente felon / felonie apareceriam como expressões para a degradação de determinados personagens, numa demonstração de estarem estes em grave erro e fadados a serem punidos por isso.

Do mesmo modo, o uso dos termos aqui analisados para os franceses decorre em alguns casos de uma ofensa moral diante de um comportamento censurável, como quando Carlos Magno desabafa diante dos barões que lhe pedem para perdoar Ganelon,

A Charlemagne repairent si barun, Dient al rei : 'Sire, nus vos prïum Que Clamez quite le cunte Guenelun, Puis si vos servet par feid e par amor. Vivre l' laisez, car mult est gentilz hoem. Ja por murir n' ert rendud gueredun, Ne por aveir ja ne l' revuverum.' Co dist li reis : 'Vos estes mi felun!' (v. 3807-3814).

\footnotetext{
${ }^{196}$ HOLLYMAN, p. 162.

${ }^{197}$ DESSAU, A. L'idée de la trahison ..., p. 24.
} 
Para o imperador o crime de Ganelon era evidente, mas seus conselheiros não se mostraram dignos ao impedi-lo de punir o responsável pelo desastre de Roncesvales, daí seu desabafo. Em outras situações, especialmente quando ditos pelos pagãos, referem-se à forma feroz como os franceses combatiam.

No Girart de Vienne há uma maior distribuição desses termos, contando felonie com 03 ocorrências e felon/fel com 24 menções:

Quadro 07: Distribuição de Felonie-felon/fel no Girart de Vienne

\begin{tabular}{|l|c|c|c|}
\hline & Felonie & Felon/fel & Total \\
\hline Ganelon & 01 & 01 & 02 \\
\hline Pagãos & - & 04 & 04 \\
\hline Carlos Magno & 02 & - & 02 \\
\hline Franceses & - & 03 & 03 \\
\hline Homens de Girart & - & 11 & 11 \\
\hline Judas & - & 01 & 01 \\
\hline Judeus & - & 01 & 01 \\
\hline Herodes & - & 01 & 01 \\
\hline Combates & - & 02 & 02 \\
\hline
\end{tabular}

Neste poema Ganelon é citado como felon e por ter feito felonie, mas isso ocorre logo no início do poema, quando o Bertrand traça o perfil da linhagem de Doon de Mayence. Não se trata de uma acusação, mas de uma desqualificação do personagem.

Os pagãos são igualmente desqualificados, através do adjetivo felon, como forma de mostrar o desprezo dos cristãos por eles.

Carlos Magno é citado em duas oportunidades, entretanto elas não estavam ligadas a atos contra seus vassalos. Um dos casos, marcando um uso sem qualquer relação com questões de fidelidade, referia-se ao olhar furioso lançado contra a rainha, após Girart dizer como ela o havia humilhado na corte:

Li enpereres a la parole oïe,

Lez lui saoit la roïne esbahie ;

Il la regarde par molt grant felonnie,

Et puis Girart a la chiere hardie.

(v. 2202-2205, grifo nosso). 
Quanto aos franceses a serviço do imperador, alguns são adjetivados apenas por irem contra os heróis do poema. Já os homens de Girart são denominados felons pela forma brutal como combatem as forças imperiais.

Judas, Herodes e os judeus recebem o adjetivo, mas como insulto. Seus atos foram moralmente condenáveis e o uso de felon para eles deveria ser um lugar comum, da mesma forma que ocorria para com os sarracenos.

Já os combates entre os guerreiros de Girart e de Carlos, pela sua violência, eram qualificados com os termos estudados aqui, mas com o sentido de ferozes ou violentos.

A Canção Renaut de Montauban tem a predominância do adjetivo felon/fel, escritos 52 vezes, enquanto há só uma ocorrência de felonie:

Quadro 08: Distribuição de Felonie-felon/fel no Renaut de Montauban

\begin{tabular}{|c|c|c|c|}
\hline & Felonie & Felon/fel & Total \\
\hline Ganelidas & - & 04 & 04 \\
\hline Ripeu & - & 04 & 04 \\
\hline Yon da Gasconha & - & 01 & 01 \\
\hline Conselheiros de Yon & - & 01 & 01 \\
\hline Carlos Magno & - & 06 & 06 \\
\hline Franceses & - & 04 & 04 \\
\hline Reinaldo & 01 & 05 & 06 \\
\hline Maugis & - & 03 & 03 \\
\hline Bueves de Aygremont & - & 06 & 06 \\
\hline Aymonidas & - & 04 & 04 \\
\hline Judas & - & 01 & 01 \\
\hline Judeus & - & 03 & 03 \\
\hline Herodes & - & 01 & 01 \\
\hline Cristãos & - & 01 & 01 \\
\hline Homens & - & 01 & 01 \\
\hline Pedreiros & - & 01 & 01 \\
\hline Ferimento & - & 01 & 01 \\
\hline Pagãos & - & 05 & 05 \\
\hline
\end{tabular}

Há uma pulverização do adjetivo, repartido entre diversos personagens e nenhum destes apresenta um quantitativo alto desses termos. Ele não é usado contra Ganelon. Poucas vezes os Ganelidas recebem essa qualificação. Do mesmo modo o rei Yon da 
Gasconha, o traidor dos Aymonidas, é assim chamado uma vez apenas. Ripeu de Ripemont, os conselheiros de Yon, os franceses, Judas, Herodes, os cristãos, os homens em sentido geral, também recebem ocasionalmente o adjetivo, mas sempre com características de ofensa e não uma acusação formal de infidelidade.

O termo é usado em relação a Carlos Magno, mas em geral se referindo à fúria com a qual recebe os conselhos para perdoar os "rebeldes" e acabar com uma guerra inútil. A raiva do rei manifesta-se através da face ameaçadora e mesmo insana dirigida contra quem o criticasse, e descrita pelo poeta com o termo felon (furiosa, terrível, ameaçadora).

Reinaldo, Maugis e Bueves de Aygremont também são nomeados felons, mas para os dois primeiros personagens consistiam em ofensas lançadas pelos homens do rei incapazes de prendê-los. Para Bueves o adjetivo tinha um caráter mais negativo, devido ao fato de ter matado o filho do imperador, mas não constituía uma clara acusação de infidelidade e sim pontuava uma característica moral dele, a sua crueldade, a sua violência. Talvez ao usar a palavra contra ele estivesse sendo levantado o defeito da vanglória, o desejo de ser igual ou melhor do que o seu superior hierárquico, Carlos Magno.

Embora pouco citados neste poema, os sarracenos, quando aparecem, recebem imediatamente o designativo de felon, termo associado de forma complementar ao seu nome em qualquer poema épico do século XII ou XIII.

No poema Gaydon Felonie aparece 07 vezes e Felon/fel 108 vezes. Comparado aos outros poemas é um número muito elevado de ocorrências:

Quadro 09: Distribuição de Felonie-felon/fel no Gaydon

\begin{tabular}{|l|c|c|c|}
\hline & Felonie & Felon/fel & Total \\
\hline Ganelon & - & 03 & 03 \\
\hline Ganelidas & 04 & 88 & 92 \\
\hline Carlos Magno & - & 01 & 01 \\
\hline Gaydon & - & 06 & 06 \\
\hline Ferraut & 03 & 04 & 07 \\
\hline Savary & - & 01 & 01 \\
\hline Gautier & - & 02 & 02 \\
\hline Judeus & - & 01 & 01 \\
\hline Herodes & - & 01 & 01 \\
\hline Perseguição & - & 01 & 01 \\
\hline
\end{tabular}


Essa presença maciça dos termos não nos deve surpreender se nos lembrarmos de que a quantidade de ocorrências de traïson / traïte /traïr é bem superior ao de felon / felonie. A própria trama do poema envolve o uso massivo de palavras, em especial adjetivos, para caracterizar os elementos perversos cuja existência na narrativa é apenas e tão somente voltada à realização de traições, sejam estas dirigidas contra o herói ou o rei.

Não se estranha, portanto, o número de vezes em que felon qualifica os membros da linhagem de Ganelon, no total, 91 ocorrências se incluirmos o traidor de Rolando. Como nos demais poemas, marca principalmente uma deficiência moral do grupo.

Os termos também são usados contra os angevinos Gaydon, Ferraut, Savary e Gautier. Entretanto devemos entender como ofensas visando rebaixar esses personagens ou provocá-los para adotarem atitudes impensadas e prejudiciais à sua causa.

As outras ocorrências são irrelevantes: uma vez para Carlos Magno, os judeus e Herodes. Um emprego para qualificar uma perseguição movida contra um dos heróis do poema.

Felon / felonie aparecem no Gaydon principalmente como um epíteto próprio para os Ganelidas, uma complemento obrigatório para ser usado quando algum de seus membros fosse apresentado ou à linhagem como um todo, quando esta realizava suas ações.

A Canção Jehan de Lançon, nos 4.146 versos considerados neste trabalho, apresenta apenas uma ocorrência de felonie e 11 casos felon/fel:

Quadro 10: Distribuição de Felonie-felon/fel no Jehan de Lançon

\begin{tabular}{|l|c|c|c|}
\hline & Felonie & Felon/fel & Total \\
\hline Ganelon & - & 04 & 04 \\
\hline Ganelidas & 01 & 02 & 03 \\
\hline Jehan & - & 01 & 01 \\
\hline Isoré & - & 01 & 01 \\
\hline Carlos Magno & - & 01 & 01 \\
\hline Basin & - & 01 & 01 \\
\hline Franceses & - & 01 & 01 \\
\hline
\end{tabular}

Novamente vemo-nos prejudicados devido à falta da parte inicial do poema, no manuscrito do século XIII do poema Jehan de Lançon. Pelo número de versos disponíveis 
o Jehan está próximo dos existentes na Chanson de Roland (4002 versos), mas a utilização dos termos aqui analisados é insignificante.

Mais da metade das ocorrências referem-se a Ganelon e seus parentes, inclusive o conde de Lançon, mostrando a associação de felon / felonie a essa linhagem. Contra Isoré, Carlos Magno, Basin e os franceses só há uma ocorrência para cada um deles.

\section{3: Termos raros, mas designativos da traição}

Além dos termos especificamente relacionados com a traição e a infidelidade existem palavras que podem tomar esses sentidos, mas usadas raramente. Em alguns casos esses termos sofreram uma adaptação, pois possuíam significados particulares, eram usados preferencialmente para outras situações distintas da traição e só eventualmente eram empregadas para substituir os vocábulos mais específicos. As Canções de Gesta trazem alguns desses casos, dos quais descreveremos os principais.

O primeiro deles é Boisier / Boisdie / Boiseor. Sua origem seria o franco bausjan, latinizado para bausia e deste último sairiam os termos românicos. No dicionário de Du Cange bausia é apresentado como "Felonia, proditio, crimen capitale" e os exemplos apresentados no verbete são de origem ibérica ${ }^{198}$. A. Iglesia Ferreiros também informa ser essa palavra um sinônimo de traição e sua origem como franca, tendo sido adotada pelos hispânicos quando da instalação de comunidades de migrantes de além-Pirineus ${ }^{199}$.

Os poemas estudados neste trabalho trazem esses termos não como designativos de um ato contra a fidelidade devida ao senhor, mas como um atentado contra o direito de outra pessoa podendo ser esta o rei ou um personagem de seu séquito. De qualquer modo designa ações condenáveis e coloca uma mácula sobre quem as realiza. No Renaut de Montauban o verbo boisier tem diversas ocorrências quando da traição feita pelo rei Yon da Gasconha ${ }^{200}$. Por ser seu vassalo, Reinaldo não acredita que Yon possa fazer-lhe algo prejudicial: "Certes ja ne crerai qu’il me voille boisier" (v. 6657), diz o herói à esposa Clarice, quando esta o alerta sobre uma possível traição. Estes termos não são muito empregados nos poemas aqui estudados, pois havia outros capazes de marcar emocionalmente os ouvintes dessas Canções.

\footnotetext{
${ }^{198}$ DU CANGE, D. Glossarium mediae et infimae latinitatis. Paris : Librairie des sciences et des arts, Tomus primus, pars II, 1937, p. 610-611.

${ }^{199}$ IGLESIA FERREIROS, A. Op. cit., p. 116-118.

${ }^{200}$ RENAUT DE MONTAUBAN, v. 6657 e ainda os versos 6700, 6738, 6743, 6755, 8337.
} 
O verbo Vendre (vender) é outro termo cuja presença na poesia épica indica a ocorrência de uma traição. Para esta ser reconhecida havia a necessidade do traidor ter recebido um pagamento ou uma recompensa pelo seu ato. Nos Evangelhos Judas Iscariótis negociou a entrega de Jesus ao Sinédrio de Jerusalém, estipulando-se o valor de trinta denários como preço por aquele que seria entregue e houve o recebimento desse dinheiro. Esse motivo levou a uma associação nos textos medievais entre as ações nas quais os heróis eram oferecidos a seus inimigos em troca de algum benefício. Este poderia ser constituído em moedas, objetos de luxo, armas, montarias, terras, cargos honoríficos. Podiam ser os pagãos quem oferecia o valor, como no caso da Chanson de Roland, onde Ganelon recebe a espada de Valdabrum, o elmo de Climborim, os dois colares da rainha Bramimonda e dez mulas carregadas de ouro dados por Marsílio ${ }^{201}$. Por conta disto, Ganelon será apresentado nos outros poemas épicos como aquele que vendeu Rolando e os doze pares da França aos sarracenos.

Todavia o próprio Carlos Magno poderia ser mostrado como quem faz a "compra" dos personagens traídos, como acontece no texto do Renaut de Montauban. Um dos lamentos de Yon quando aceita mandar os quatro filhos de Aymon para uma emboscada é justamente "Venduz vos ai a Kalles le nobile guerrier" (v. 5457) e vendre é usado em outras oportunidades para o ato cometido pelo rei gascão ${ }^{202}$. Entretanto, é o rei da Gasconha quem assume a condição de traidor por vender seus homens ao imperador.

Parjure, parjurer são expressões ligadas à violação de um juramento. Como este era prestado tomando Deus e seus santos como testemunhas e realizado em um ritual no qual objetos sagrados, livros ou relicários, eram tocados, desrespeita-los era visto como um pecado grave. Quem perjurasse perdia a proteção divina estava sujeito a um castigo pelas forças sobrenaturais, mas os próprios homens, em especial os prejudicados pelo ato, poderiam punir o responsável. Quando Thierry fez a acusação de Ganelon, afirmara ter este sido perjuro a Carlos Magno, violando sua promessa de servi-lo lealmente enquanto a palavra traição era reservada para o ato contra Rolando ${ }^{203}$.

Ocasionalmente encontramos a expressão foi mentie em alguns poemas épicos. Tal como parjure ela se refere ao rompimento de um juramento de fidelidade e sujeita o responsável pela falta a uma punição.

\footnotetext{
${ }^{201}$ CHANSON DE ROLAND, v. 617-641; 647-660.

202 RENAUT DE MONTAUBAN, v. 7303, 7369, 7576, 8338, 9237.

${ }^{203}$ CHANSON DE ROLAND, v.3824-3836.
} 
Encontramos também o nome de Judas associado a um traidor ou a um ato de traição, uma comparação negativa que visava mostrar o personagem a ele relacionado como um criminoso, alguém responsável por ações condenáveis e cuja dignidade moral era nula ou era rebaixada como consequência de seu comportamento. O Renaut de Montauban apresenta dois episódios onde há esse emprego. O primeiro decorre do estratagema de Herves de Lausanne para tomar o castelo de Montessor e prender os quatro filhos de Aymon. Como ele mentiu para ser admitido na fortaleza e ofereceu uma imagem e palavras contrárias às suas verdadeiras intenções houve a associação com Judas:

Hervis ne dormi mie, li cuvert renoiez Qui en leu de Judas fu laienz herbegiez.

(v. 2889-90)

O outro evento foi a atitude do rei Yon da Gasconha ao conduzir os Aymonidas para a emboscada imperial em Vaucoulours. O próprio Yon se censura por estar realizando tal ato, ele mesmo se compara a Judas e se coloca na mesma posição daquele que traiu Cristo e não mereceu perdão:

A la loi de Judas me sui ci herbegié : Vendu vos ai a Kalles le nobile guerrier. Dameldeu en perdrai le Pere droiturier, $N$ 'i serei racordez por nule rien soz ciel. (v. 6456-59)

Uma palavra em francês medieval muito próxima da traição é murdre, também escrita murtre e em latim murtrum, mutrum, mudru, murdrum ${ }^{204}$. Ela designa, no francês atual, meurtre, o assassinato. Trata-se do homicídio cometido sem dar chances de defesa à vítima, de preferência com esta desarmada. Encontramos uma boa definição desse crime em Felipe de Beaumanoir ${ }^{205}$,

825. Murtres si est quant aucuns tue ou fet tuer autrui em aguet apensé puis soleil esconsant dusques a soleil levant, ou quant il tue ou fet tuer en trives ou en asseurement.

E o mais interessante é o quão próximo o bailio do Beauvaisis coloca murdre da traição,

${ }^{204}$ DU CANGE, Glossarium ..., T-V, p. 524-526.

${ }^{205}$ PHILIPPE DE BEAUMANOIR, p. 429-430. Na Summa de legibus Normannie in curia laicali, o capítulo LXVII é intitulado De Multro e trata não apenas dos atos assim qualificados, mas também como se devia proceder no julgamento, os juramentos e a questão do duelo judicial para esses casos. COUTUMIERS DE NORMANDIE, T-II, p. 167-174. 
827. Nus murtres n'est sans trä̈son, mes trä̈sons puet bien estre sans murtre en mout de cas; car murtres n'est pas sans mort d'homme

Assim, murdre (assassinato) era uma forma vista como condenável de se matar alguém em uma sociedade onde os homicídios poderiam ser justificados. Desde que tivessem sido seguidos determinados procedimentos como, no caso da vingança, ter declarado a existência da hostilidade entre dois homens ou duas linhagens e o motivo dela. Também o ataque durante a noite era condenado, por deixar desprotegida a vítima e proteger o agressor, além de impedir a identificação deste. Quando era acertada uma trégua para o conflito ou era garantida a segurança de alguém, atacá-lo ou matá-lo representava violar os costumes legais e podia levar a alguma forma de sanção sobre o agressor.

Existem várias ocorrências de murtrir no poema Gaydon $^{206}$. São normalmente atos planejados pelos Ganelidas contra Carlos Magno ou contra Gaydon e seus homens. Tratase das tentativas de emboscada aos angevinos ou o projeto da má linhagem para se livrar do imperador e tomar-lhe a coroa. Em outros poemas essa palavra e suas congêneres não aparecem com frequência, pois não existe uma conspiração permanente como ocorre nesta Canção. Na Gesta Renaut de Montauban há duas aplicações dos termos próximas ao apontado por Felipe de Beaumanoir em seu Coutumier. Após a morte de Bueves de Aygremont, Maugis dirige-se ao seu tio Girart de Roussillon e afirma "Li rois l'a fet murdrir com traïtor morter" (v. 1632), pois o próprio monarca havia oferecido um salvoconduto para o barão ir com segurança para Paris e pedir perdão por haver morto Lotário. Outro verso onde aparece o termo ocorre quase no final do poema, quando os pedreiros de Colônia decidem pela morte de Reinaldo. Conforme o poeta, «Tant ont parlé ensenble que il sera murtri» (v. 14202). Se no primeiro caso Carlos criou condições para a emboscada (guet apensé) de Bueves, pegando-o de surpresa e sem dar oportunidade de escapar, no segundo houve um conluio entre os pedreiros para agir mortalmente contra o herói sem serem descobertos pelo seu crime. A agravante da ocultação do cadáver, jogando-o no rio, é até mesmo um dos exemplos tirados por Du Cange num dos verbetes de definir o murdrum $^{207}$.

Consideramos essas palavras as mais próximas como designativas da traição e elas aparecem ocasionalmente na poesia épica francesa, embora os poetas já tenham os seus

${ }^{206}$ GAYDON, v. 3165, 5876, 5920, 5988, 5989, 6392, 6452, 6546, 6595, 6735, 6922, 7513,7629, 8513, $9467,10112,10334,10354,10530,10807$.

${ }^{207}$ DU CANGE. Glossarium ..., p. 525. Lex Bajwar. Tit. 18, §1 : Si quis liberum occiderit furtivo modo, et in flumen ajecerit, vel in talem locum, ut cadaver reddere non quiverit, quod Bajwarii Murdrido dicunt, etc. 
vocábulos preferidos para designar esse crime. Por esse motivo nós nos detivemos pouco no estudo destas, sem dar a atenção e o cuidado expositivo empregado quando do estudo dos vocábulos traïson e felonie e seus associados.

\section{4: Palavras que podem tomar o sentido de traição}

Ao final deste estudo, devemos considerar a existência, nas Canções de Gesta, de palavras designando ações que, em determinado contexto, especialmente quando ligados às questões de fidelidade ou de companheirismo podem ser entendidas como menções veladas à traição. Em geral elas decorrem do estilo formulário da poesia épica francesa, são frases feitas, decoradas pelo poeta para a criação da narrativa por ele transmitida, seguindo o mesmo esquema através do qual são criados os relatos de combate à cavalo utilizando-se da lança ou da espada e o desenrolar das assembleias onde um senhor deve tomar uma decisão orientado pelos seus vassalos, conforme expos J. Rychner ${ }^{208}$.

Dois verbos aparecem com muita frequência nas Canções, mas eles não designam atos condenáveis cometidos por algum personagem e sim, predominantemente, aparecem em frases de cavaleiros nas quais se afirma de modo peremptório que não se incorrerá em um malfeito, fosse este a fuga do campo de batalha ou o abandono do senhor ou líder devido aos perigos do combate.

Um desses verbos é Faudra, que traduzimos por "faltar". Ele é proferido antes ou no decorrer das refregas, em geral como resposta a um questionamento de quem comanda a hoste, fosse este Carlos Magno ou qualquer um dos heróis épicos. Quando Olivier conclama os franceses para se prepararem para a batalha:

Dïent Franceis:Dehét ait ki s'en fuit! Ja pur murir ne vus en faldrat uns.

(v.1047-48)

E nos demais poemas esse tipo de discurso será repetido: assim respondem os vassalos de Girart de Vienne "qui vos faudra si soit vis recreant!" (v. 3177); Ogier afirma em relação aos quatro filhos de Aymon, “Jamés ne lor faudrai tant com je soie vif” (v. 8041); durante um combate no Gaydon, Naimes diz a seu filho Richer a respeito de Carlos Magno, "Ne por nul home ne li faudrai nul jor" (v. 9504).

$\overline{{ }^{208} \text { RYCHNER. Op. cit., p. 141-153. }}$ 
O outro verbo é Faillir, "falhar", no caso falhar em relação à fidelidade devida ao líder ou ao companheiro de armas. É outro tipo de ação a ser evitada e, para demonstrar o caráter e o quanto se é fiel, são recorrentes os discursos de cavaleiros nos quais se afirma que não se incorrerá nessa vergonha. Na Chanson de Roland podemos encontrar dois usos para esse verbo, um deles louvável, como quando os pagãos falam dos franceses em relação a Carlos Magno: "Fiers sunt si hume, n’unt talent qu’il li faillent" (v. 3133). Em sentido inverso tem-se a constatação pelos pagãos da impotência de seus deuses, nas palavras de Bramimonda: "Cest mien seignur en bataille faillirent" (v. 2718).

A insistência no uso de fórmulas nas quais esses vocábulos aparecem talvez não seja apenas decorrente da necessidade de ter versos prontos para a criação poética em um meio no qual a oralidade e a memória ainda dominam. O martelar constante das frases "não vos faltarei" ou "não vos falharei por temor à morte" para um público composto principalmente de guerreiros, cuja moral induzia à coragem por vezes desmedida e à necessidade de respeitar os compromissos assumidos perante um chefe ou amigo, era um reforço para esse comportamento belicoso e de camaradagem. Era um modo de gravar nas mentes dos cavaleiros uma forma de conduta utilizando-se para isso uma frase na qual se nega a possibilidade de incorrer em determinada falta.

Como pudemos observar, a nomeação da traição nas Canções de Gesta dispõe de vocábulos específicos nas palavras herdadas do latim traditio / tradere / traditor, cujo sentido pejorativo decorre de seu emprego neotestamentário para nomear o ato de entrega de Jesus por Judas Iscariótis. Dominam na poesia épica os termos trä̈son / traïr / traïtre, sendo empregadas para designar os atos voltados à morte ou à perdição de alguém ao qual se devotou um ódio exacerbado e envolve alguma forma de dissimulação que permita o sucesso da ação. Seu uso inicial visava os barões do mesmo nível do traidor, mas pertencentes a uma linhagem diferente, como era o caso de Rolando (Roncesvales, Lançon), Reinaldo de Montauban (Montessor e Vaucoulours), Thierry - Gaydon. Foi preciso esperar o final do século XII para as Canções utilizarem trä̈son como um ato dirigido contra o rei, de modo a estender o campo de aplicação da terminologia dos casos de cunho pessoal para casos eminentemente políticos, como o complô para derrubar o rei.

Se havia muitas outras palavras passíveis de assumir o significado de traição ou infidelidade, a que menos parece tomar esse sentido é justamente felonie / felon, pois designava principalmente caracterísicas negativas (crueldade, violência, ferocidade, maldade) e quem as tinha. Encontramos muitas situações onde traïtre e felon aparecem no 
mesmo verso ou em versos próximos, mas tratava-se de uma forma do poeta vilipendiar a imagem daquele de quem ele falava.

Dos diversos outros termos, suas origens são variadas: latina (parjurer), germânica (boiser, murdre), adaptação da tradição bíblica (vendre, judas). Também podem ser palavras adaptadas a uma determinada situação, relacionada à confiança entre os homens (faillir, faudra).

Com esse levantamento temos uma ideia do vocabulário disponível para os jograis e poetas criadores e difusores das Canções de Gesta. Estes trabalhavam com a emoção de seu público e essas palavras deveriam ter, quando pronunciadas, um forte efeito sobre a sensibilidade dos ouvintes desses poemas. Eram termos conhecidos do ambiente aristocrático-cavaleiresco e nomeavam faltas censuradas nesse meio e, portanto, não poderiam deixar os membros desse grupo indiferentes aos episódios onde assas palavras surgiam. 


\section{3- OS TRAÍDOS E OS TIPOS DE TRAIÇÃO}

Passando ao estudo das fontes, a nossa atenção será dirigida primeiramente para os personagens vítimas da traição nas Canções de Gesta. Não nos limitaremos apenas a identificar quem são eles e a posição que ocupam na hierarquia feudo-vassálica. Também atentaremos para as formas como se manifestam as ações contra eles dirigidas. No final tentaremos cruzar as informações existentes na poesia épica com alguns dados extraídos dos escritos legais, os Costumes (Coutumiers), colocados por escrito no século XIII.

\section{1- Os cavaleiros e vassalos}

Pelo que pudemos verificar nas leituras feitas, a traição na épica medieval francesa era dirigida inicialmente contra os cavaleiros e os vassalos, representados como os heróis das diversas narrativas. Eles eram mostrados como exemplos de coragem, virtude e fidelidade. Por conta disso tornavam-se vítimas da inveja e de atos hostis por parte de outros membros da corte de Carlos Magno.

Os traídos e os traidores pertenciam, em geral, ao mesmo nível social e hierárquico. Eram todos barões importantes, guerreiros reputados como destemidos e constituam linhagens com numerosos membros, detentores de importantes propriedades e riquezas. Também eram frequentemente chamados para aconselhar seu senhor sobre os mais diversos assuntos, em especial os relativos às guerras. Todavia, houve uma polarização conscientemente concebida pelos poetas, na qual as diversas famílias que compunham o império franco eram divididas em dois grupos antitéticos: um deles era considerado virtuoso e tornava-se alvo de constantes traições; o outro grupo, firmemente ligado pelo sangue, era mostrado como sendo responsável pelas tramas visando destruir os heróis épicos.

Começando pelo poema considerado o mais antigo, a Chanson de Roland do manuscrito de Oxford, temos como traídos Rolando, sobrinho do imperador, e os pares da França. Eles formavam um grupo de privilegiados dentro da corte imperial e, com seus 
vinte mil cavaleiros ${ }^{209}$, constituíam a ponta de lança das hostes de Carlos Magno, a tropa de elite responsável pelo início dos combates e a garantia de que as batalhas seriam vencidas pelos cristãos. A crença nisso é apresentada no poema através dos discursos dos pagãos. Para eles, morta essa elite, os demais cavaleiros franceses não representavam nenhum poder capaz de resistir-lhes ao ataque, como diz Baligant ao conduzir suas tropas contra as de Carlos,

Ier fu ocis le bon vassal Rollant,

E Olivier li proz e li vaillanz,

Li duze per qui Carles amat tant,

De cels de France vint milie cumbatanz;

Trestuz les altres ne pris jo mie un guant.

(v. 3185-89)

Levar à perda esses guerreiros era enfraquecer o imperador, o reino e a própria Cristandade, vista a partir de então como incapaz não só de expandir-se, mas também de defender seus territórios de um avanço pagão. A bravata de Margariz de Sevilha diante de Marsílio, “Jusqu'a un an avrum France saisie; / Gesir purrum el burc de seint Denise" (v. 972-3), constituía um aviso da ameaça a pairar sobre o mundo cristão.

Na narrativa, Rolando foi traído por provocar Ganelon, seu padrasto, quando da escolha do embaixador encarregado de impor as condições de paz de Carlos a Marsílio. Entretanto há algo nos versos relativos à assembleia que indicam a existência de uma diferença antiga entre os dois personagens. Após o imperador pedir conselho aos seus barões, Rolando defende a continuidade da guerra, começando seu discurso com a expressão "Ja mar crerez Marsilie!" (v. 196), para alertar a todos sobre o caráter mentiroso do rei pagão. Ganelon é o segundo a falar e retoma o início do discurso do enteado de um modo agressivo, "Ja mar crerez bricun (= tratante)" (v. 220), direcionando claramente essas palavras contra Rolando. Não existe uma Canção de Gesta na qual seja explicado o motivo para esse comportamento hostil. Encontramos na versão La Valière do poema Renaut de Montauban uma promessa de vingança devido à morte dos sobrinhos de Ganelon após o duelo judicial contra os filhos de Reinaldo ${ }^{210}$. Na Karlamagnus Saga ${ }^{211}$,

\footnotetext{
${ }^{209}$ As Canções de Gesta apresentam predominantemente combates entre cavaleiros e exércitos formados apenas pela cavalaria. Unidades de infantaria, os pedites, não tem lugar nessa literatura voltada ao enaltecimento dos valores cavaleirescos. As menções de arqueiros são ocasionais; grupos de mercenários contratados para fazer a guerra não são citados. O mundo da poesia épica, nesse campo, difere totamente daquele real da França dos séculos XII e XIII, onde arqueiros e mercenários competem com os cavaleiros quando das ações militares.

${ }^{210}$ CHANSON DES QUATRE FILS AYMON (La). D'après le manuscrit La Vallière, par Ferdinand CASTETS. Genève: Slatkine, 1974, p. 873, «Par Diex, dist Guenelons, qui se laissa estandre, / Encor venra
} 
versão norueguesa de algumas narrativas épicas francesas, a antipatia de Ganelon por seu enteado decorre do fato da sua primeira esposa ter tentado seduzir Rolando e apesar deste rejeitar o avanço da mulher e contar o ocorrido ao marido desta, ainda assim, criara-se uma inimizade latente. Além desta versão há outra, possivelmente mais difundida, na qual Rolando não seria sobrinho de Carlos Magno e sim seu filho, fruto pecaminoso do incesto com sua irmã Gilles (ou Gisele) ${ }^{212}$. Ganelon guardaria esse segredo e não se conformaria com esta situação, a ponto de odiar seu enteado ${ }^{213}$.

De nossa parte, podemos pensar em outro motivo para o ódio do padrasto. Todo matrimônio envolvendo grandes famílias no medievo francês comprometia os interesses das linhagens. No caso de uma união da mulher de uma linhagem superior à linhagem do marido, este último procurava ascender social e materialmente e, com isto, fortalecer seu clã ou dar início à uma casa dominial nova, como descreveu Georges Duby ${ }^{214}$. Em princípio a união de Ganelon com a irmã do imperador elevaria ele e sua família na corte e no reino. Entretanto há um filho do primeiro casamento de sua esposa, Rolando, herdeiro das honras de seu pai e, na condição de sobrinho, um favorito privilegiado do rei. As vantagens do matrimônio estariam anuladas enquanto esse enteado continuasse vivo.

Mas a traição não atingiu apenas um indivíduo, no poema. O peso da solidariedade entre os homens agiu no pensamento de Ganelon, pois se Rolando sofresse alguma represália os outros pares da França também deveriam sofrer uma vez que estavam ligados pela lealdade e pelo afeto ao sobrinho do imperador. O desafio do padrasto fora bem claro ao responsabilizar o enteado pela sua escolha como mensageiro em Saragoça, com risco de perder a vida,

\footnotetext{
"Sire”, dist Guenes, “ço ad tut fait Rollant:

Ne l'amerai a trestut mun vivant

Në Olivier, por ço qu'est si cumpainz;

Li duze per, por ço qu'il l'aiment tant,

Desfi les ci, sire, vostre veiant."
}

(v. 322-26)

\footnotetext{
.I. jours, à Charle lo cuit rendre. / Il dist voir li traïstres, ains ne deigna [mesprendre] ; / Puis vendi toz les pers, si en fist les chiés prendre. » (v. 17797-800).

${ }^{211}$ SAGA DE CHARLEMAGNE, Chap.LVI, p. 134-136.

212 GAIFFIER, Baudouin de. La légende de Charlemagne. Le péché de l'empereur et son pardon. In: Recueil de travaux offerts a M. Clovis Brunel. Paris: Bibliothèque de l'École des Chartes, 1955, T-I, p. 490-503.

${ }^{213}$ CLEJ, Alina. Le miroir du Roi. Une réflexion sur la Chanson de Roland. Romance Philology, vol. XLIV, $1990, \mathrm{n}^{\circ} 1$, p. 36-53.

${ }^{214}$ DUBY, Georges. O cavaleiro, a mulher e o padre. O casamento na França feudal. Lisboa: Dom Quixote, 1988, p. 161-198, os capítulos referentes às linhagens dos senhores de Amboise e dos condes de Guines.
} 
Se os pares da França formavam um corpo unido por uma fidelidade recíproca, todos os membros deste pagariam solidariamente pela afronta feita por um deles. Talvez fosse, também, uma forma de evitar uma desforra posterior, pois o ideário de vingança seria assumido pelos mais próximos da vítima ${ }^{215}$. E os mais ligados a Rolando eram os outros pares, seus companheiros de combate.

Há vários estudos nos quais se tentou mostrar a ideia central através da qual foi conduzida a criação e/ou a escrita da Chanson de Roland. No rol de motivos estaria a desavença entre Rolando e Ganelon ou a antítese heroica entre o bravo Rolando e sábio Olivier. Para nós a explicação encontra-se na necessidade de justificação para o desastre de Roncesvales, evento ocorrido em 778, cuja lembrança marcou profundamente a história franca, fosse esta oficial nas crônicas e anais escritos em latim ou a poética narrada ou cantada em língua vulgar ${ }^{216}$. Somente após a morte de Carlos Magno essa derrota foi mencionada nos textos em latim, mas presume-se que se manteve viva na memória de quem viveu ou ouviu de testemunhas o relato da batalha. A traição perpetrada por um dos membros da hoste franca era a única resposta para questão de como um exército cristão, comandado por um monarca vitorioso e invicto, movendo guerra aos inimigos da fé, poderia ter sido derrotado pelos infiéis.

Uma situação levantada no decorrer do poema era se o monarca poderia ter traído os doze pares ao permitir a sua exposição na retaguarda da hoste. O sobrinho de Marsílio lançara essa acusação quando do início do combate: "Traït vos ad ki a guarder vos out" (v. 1192), deixando a entender ter o imperador abandonado os vassalos a quem deveria, por obrigação, defender. Rolando matou o acusador e negou a possibilidade do imperador ter cometido semelhante falta: "Ne traïsun unkes amer ne volt" (v. 1208). Há pesquisadores que vêem no texto uma responsabilização de Carlos Magno, assim como de Ganelon, no desastre de Roncesvales. O rei, como senhor feudal, tinha por obrigação defender seus homens e Carlos não impediu o seu sobrinho de assumir a posição mais exposta da retirada franca, apesar dos sonhos premonitórios tidos na noite anterior à escolha da retaguarda e da vanguarda de seu exército e da desconfiança quanto a designação feita pelo seu cunhado ${ }^{217}$. Mas não havia o que ser feito pelo monarca, pois a assembleia dos barões aceitara o acordo de paz com Marsílio, Ganelon retornara de Saragoça afirmando a boa-fé do pagão, ninguém na hoste contestou a escolha de Rolando para a retaguarda e o sobrinho do

\footnotetext{
${ }^{215}$ BLOCH, M. Op. cit., p. 183-192.

${ }^{216}$ HORRENT, Jules. La bataille des Pyrénées de 778. Le Moyen Age, T-LXXVIII, 1972, no 2, p. 197-227.

${ }^{217}$ HAIDU, Peter. The Subject of Violence. The Song of Roland and the Birth of the State. Bloomington; Indianapolis: Indiana University Press, 1993, p. 85-100.
} 
imperador, movido pelo orgulho, não só aceitou a posição como ainda recusou um reforço composto da metade da hoste franca oferecido por seu tio ${ }^{218}$.

No Renaut de Montauban vemos a traição aos Aymonidas também tomava um caráter horizontal, pois são principalmente barões e cavaleiros do mesmo nível social deles os responsáveis pela sua ocorrência.

Um dos primeiros casos narrados no poema envolveu Herves de Lausanne, tendo este se oferecido junto ao rei para capturar ou matar os quatro filhos de Aymon então alojados na fortaleza de Montessor $^{219}$. Este castelo mostrou-se inexpugnável e os cavaleiros de Reinaldo eram imbatíveis quando resolviam sair dele para atacar o acampamento imperial, apesar do grande número de guerreiros trazidos pelo imperador para o assédio. O único jeito de conseguir derrotá-los seria recorrer a alguma forma de ardil, um procedimento antigo na epopeia ocidental, usado desde as narrativas de Homero.

Herves jurou ao rei entregar Reinaldo, pediu a preparação de uma pequena tropa e deixou a hoste real, dirigindo-se sozinho à fortaleza cercada onde alegou ter caído na ira do rei por defender os Aymonidas,

Acuilliez moi lä̈n, por Deu li criator! Meslé me sui a Karles le noble empereor Tot por les filz. Aymon que il fet dessenor.

Aceito dentro do castelo, agindo como um Judas, ou "Qui en leu de Judas fu laienz herbegiez" (v. 2890), ele esperou o anoitecer para abrir os portões e permitir a entrada do destacamento imperial para ocupar o local ${ }^{220}$. Houve o uso do engano, da dissimulação e da mentira para se atingir um objetivo prejudicial àqueles a quem se oferecera a amizade. Ao apresentar-se diante de Montessor e pedir guarida, Herves obteve a confiança dos filhos de Aymon e, embora não tenha prestado nenhum juramento de fidelidade a estes, fora considerado como parte do grupo ali instalado. Por esse motivo, após a sua derrota, a punição que recebeu foi atroz e digna de um traidor, segundo o poeta.

Mais grave, entretanto, foi a traição perpetrada pelo rei Yon da Gasconha, o senhor imediato dos Aymonidas, após a instalação destes nas suas terras. Reinaldo e seus irmãos

\footnotetext{
${ }^{218}$ CHANSON DE ROLAND, v. 783-791.

${ }^{219}$ RENAUT DE MONTAUBAN, v. 2813-2857.

${ }^{220}$ O episódio pode lembrar a lenda do "Cavalo de Tróia", onde os gregos ofereceram essa construção de madeira com guerreiros escondidos para poder entrar na cidade. Mas não acreditamos ter o poeta tal narrativa em mente quando elaborou a trama de Herves de Lausanne, pois este ofereceu a si mesmo, de forma mentirosa, como aliado daqueles a quem desejava destruir aproveitando-se da boa-fé destes em relação à sua pessoa. É uma situação que veremos descrita nos Coutumes, mais adiante.
} 
sempre se mostraram vassalos fiéis a Yon, ajudando-o a derrotar uma invasão sarracena e, depois, combatendo e submetendo os barões indóceis ao rei ${ }^{221}$. Uma vez que cumpriam suas obrigações, não havia motivo para esses vassalos desconfiarem da má-fé de seu senhor. Pelo contrário, esperavam a ajuda deste para enfrentar a ameaça representada pela hoste de Carlos Magno ou a intermediação de Yon visando um acordo com o imperador objetivando a paz definitiva deste com os jovens cavaleiros. Como agravante havia a questão de Reinaldo ser cunhado do rei gascão, devido ao seu matrimônio com Clarice, portanto os laços entre esses homens deixavam de ser apenas vassálicos, decorrentes de um contrato, para se tornarem familiares. Apesar disso esse monarca não teve escrúpulos em mandar uma missiva ao imperador franco informando como seria feita a traição e, depois, apresentar-se em Montauban não apenas mostrando amizade, mas ainda cobrando manifestações de fidelidade de Reinaldo e de seus irmãos. Calando sobre suas reais intenções e exigindo dos jovens que se apresentassem praticamente desarmados diante de seu adversário, o senhor gascão tinha certeza de qual seria o destino deles: a morte pelas armas dos franceses.

Embora as ameaças de Carlos Magno representassem um fator novo e externo para ser revista a aliança com os Aymonidas, por trás da ação traidora de Yon havia outra motivação, esta alheia à vontade do rei e baseada na inveja dos demais barões da Gasconha aos filhos de Aymon. Os jovens heróis haviam chegado como exilados em busca de um senhor para sustentá-los e foram aceitos por Yon, este sabendo do ódio de Carlos aos rapazes. Logo Reinaldo e seus irmãos haviam adquirido enorme ascendência sobre o rei em detrimento dos demais membros da sua corte, a ponto de obterem a permissão de construir uma cidade-fortaleza, Montauban, considerada ameaçadora até para seu próprio senhor, na visão de alguns conselheiros. Para agravar o sentimento de hostilidade dos cortesãos, Yon dera sua irmã em casamento a Reinaldo, um estrangeiro, em detrimento dos demais grandes do seu reino. Convocados para dar seus conselhos, pois o próprio rei admitira "Je ne sui qu’um selx hom, conseillier me devez" (v. 5982), esses barões se sentiram fortes o bastante para colocar seu senhor na obrigação de acatar sua decisão, mesmo sendo esta originada da inveja.

O próprio Yon associou a entrega dos Aymonidas ao imperador com a entrega de Jesus por Judas e, como este, ele se viu condenado eternamente, deixando isso claro ao ser bem recebido em Montauban,

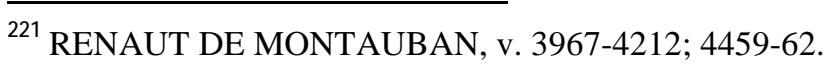


Por quoi me faites joie, nobile chevalier?

A la loi de Judas me sui ci herbergié :

Venduz vos ai a Kalles le nobile guerrier.

Dameldeu en perdrai le Pere droiturier,

$N$ 'i serai racordez por nule rien soz ciel.

Hon qui traïst tel gent a bien Dez renoié.

(v. 6455-60).

O rei gascão age com remorso e, após a conclusão do episódio, com a vitória dos quatro filhos de Aymon, ele renuncia à coroa e entra para um mosteiro, onde pretende penitenciarse pela sua falta, e isto ameniza as censuras diretamente a ele dirigidas ${ }^{222}$.

Sobre a traição dos franceses em Vaucoulours, tão citada no decorrer da narrativa da emboscada, primeiro é preciso observar que boa parte da força usada no combate foi composta de Ganelidas, estando estes interessados em agradar Carlos Magno e, assim, ganhar mais influência na corte deste. Se Ogier o Dinamarquês participou com seus homens da empreitada, diz o poeta, fez isso por imposição do rei franco, a quem fora obrigado a jurar obediência e a cumprir uma ordem injusta ${ }^{223}$. No local da emboscada deveria realizar-se o encontro para o acordo de paz com o Carlos e o perdão deste aos Aymonidas. Convencidos da sinceridade da oferta, estes últimos se apresentam sem armamento ofensivo e sem montarias de combate. Ao serem atacados estão em total desvantagem material e numérica em relação aos agressores. Com isso a traição contra eles apresenta-se sob dois aspectos, o primeiro é a tentativa de se matar alguém sem darlhe oportunidade de defesa, o que corresponderia a um assassinato ou murdre, severamente condenado pela legislação medieval. $\mathrm{O}$ segundo aspecto é da violação da moral cavaleiresca, pois não se respeita a condição do adversário atacado, praticamente desarmado, não sendo permitido a este combater de igual para igual com os agressores, e usou-se da falsidade para atraí-lo para uma armadilha.

O poema Renaut de Montauban apresenta ainda algumas traições pontuais, no caso, as cometidas pelo sapateiro de Paris e pelos serventes de pedreiro de Colônia ${ }^{224}$. Elas envolveram a ação de pessoas pertencentes a um grupo social inferior ao do herói cavaleiresco e, uma característica frequente neste poema, os faltosos estavam estabelecidos nos meios urbanos, fugindo dos estereótipos camponeses de outras Canções. No caso do sapateiro de Paris, este servira de hospedeiro para Reinaldo e Maugis quando estes

${ }^{222}$ SPIJKER, Irene. Le roi Yon: homme pitoyable ou traître félon? In: ACTES DU XIe CONGRÈS INTERNATIONAL DE LA SOCIÉTÉ RONCESVALS, Barcelona, 22-27 aôut 1988. Memorias de la real academia de buenas letras de Barcelona, vol. 21-22, 1990, Tome II, p. 231-240.

${ }^{223}$ RENAUT DE MONTAUBAN, v. 6296-6313.

${ }^{224}$ Ibid., v. 5060-5108, para o sapateiro de Paris; v. 14145-14264, para os serventes de pedreiro. 
chegaram disfarçados à cidade, para participar da corrida de cavalos promovida pelo imperador. Ao descobrir quem eram seus hóspedes o artesão correu para denunciar ao rei a presença dos dois heróis, pois havia ordens régias para isso ser feito, mas não conseguiu realizar o seu intento porque foi perseguido e morto por Reinaldo. Se a intenção de entregar os primos ao poder real fez o sapateiro ser visto como traidor, o ato do Aymonida não foi isento de censura por parte de Maugis ${ }^{225}$, pois quem morrera lhes dera acolhida e violara-se, assim, um dos princípios a reger as relações humanas medievais, o da hospitalidade. Para nós esse episódio pode parecer um tanto desconcertante, uma vez que os heróis eram tão censuráveis por esconder suas identidades, quanto seu hospedeiro delator. Entretanto o poeta desenvolveu sua narrativa com um pensamento simples: todo ato contrário aos Aymonidas ou a Maugis seria considerado uma traição e seu realizador deveria ser vilipendiado.

Já a ação movida pelos serventes de pedreiro em Colônia teve uma característica diferenciada, o de aproximar a morte do herói a um martírio. Tornado um penitente, Reinaldo ofereceu seus serviços como trabalhador braçal na construção da catedral da cidade e, devido à sua penitência, recebia um salário insignificante por um rendimento no trabalho superior ao dos demais trabalhadores da obra. Ao fazer isso ele foi visto como uma ameaça aos ganhos monetários dos outros pedreiros e serventes e estes resolveram matá-lo e esconder-lhe o cadáver ${ }^{226}$. Novamente há uma associação da traição com o assassinato (murdre), pois o ataque foi feito sem ser anunciado e de modo a não dar oportunidade para vítima escapar. Reinaldo não chegou a ver de onde veio a pedra jogada sobre sua cabeça. Além disso, houve a agravante de se desfazerem do corpo, jogando-o no Reno, para que o crime não viesse a ser descoberto.

Ainda na Gesta Renaut de Montauban, encontramos problemas quando tratamos do personagem Bueves de Aygremont, pois este foi alvo de uma traição movida pelo próprio imperador. Entretanto ele também cometeu atos censuráveis e graves o suficiente para fazer dele um traidor. Aqui nos limitaremos a tratar da sua condição de vítima, deixando para o próximo capítulo a sua caracterização como culpado de vários erros perante seu senhor.

Bueves cometera três atos condenáveis contra Carlos Magno: não se apresentara à hoste reunida para combater os saxões, matara Lotário, o filho do rei, enquanto mensageiro

\footnotetext{
${ }^{225}$ Ibid., v. 5106-07: «Qu'as tu fet, vis deable? As tu le sens desvé, / Que nostre hoste as ocis meïsme en son osté?»

${ }^{226}$ Ibid., v. 14181-230.
} 
de seu senhor, e reunira um exército para invadir as terras imperiais. Apesar disso recebera uma proposta de paz e de perdão se fosse prestar homenagem a Carlos em Paris. Para poder realizar a viagem, o monarca lhe ofereceu um salvo-conduto garantindo-lhe a integridade física. Mas ao saber da vinda do barão, o imperador começou a mudar de intenção e o desejo de vingança tornou-se mais forte do que uma possível compensação oferecida pelo criminoso. O clã ganelida, aproveitando-se da inconstância do rei, incentivou-o a emboscar Bueves, pois este estaria vulnerável a um ataque ${ }^{227}$. E de fato, o barão faz a viagem com poucos cavaleiros de escolta e não acreditava na possibilidade de ser atacado por ordem do rei, uma vez ter este comprometido sua palavra no salvo-conduto e, conforme afirmara Ogier o Dinamarquês, se Carlos violasse sua promessa "Que li monz l'en tendroit a traïtor provez" (v.1343), algo degradante para um monarca cristão coroado. O senhor de Aygremont caiu na armadilha e foi morto, não havendo possibilidade de fuga para ele, ao contrário do destino de seus sobrinhos, capazes de superar todas as traições armadas contra eles em Montessor e em Vaucoulours.

Em certo sentido e sem o poema dizer isso com clareza, vemos o episódio desse assassinato como a consequência final da morte de Lotário pelas mãos de Bueves. Se o barão foi vítima de uma traição de seu rei, ele também fora o algoz do filho deste. Ao contrário dos Aymonidas, não havia como o poeta pudesse desenvolver um enredo no qual Bueves escapasse vivo da emboscada, pois o crime por ele cometido ameaçava a ordem do reino, uma vez que o filho de um monarca era, com grande possibilidade, o herdeiro e sucessor da coroa. Para esse ato criminoso não haveria perdão ${ }^{228}$.

Ao lermos o poema Gaydon vemos a traição aparecer estreitamente ligada a tentativas de vingança, constituindo um meio pelo qual esta poderia ser conseguida com sucesso. Como Thierry/Gaydon foi o responsável por provar a traição de Ganelon, vencendo e matando em duelo a Pinabel, o jovem atraiu para si o ódio da linhagem destes. E, também, por ser um dos favoritos de Carlos Magno, tal como Naimes da Baviera e Ogier o Dinamarquês, o angevino era vítima da inveja do clã ganelida, como se depreende das palavras amargas de Alori ao observar as tendas do acampamento imperial no início do poema:

\footnotetext{
${ }^{227}$ Ibid., v. 1118-1556.

${ }^{228}$ Como todos os textos das Canções de Gesta disponíveis, editadas ou não, o do Renaut de Montauban é um remanejamento no qual foram escolhidas algumas aventuras e estas foram adaptadas de acordo com o gosto do poeta / jogral e o seu desejo de agradar um público aristocrático cavaleiresco. O episódio de Bueves de Aygremont pode não ter feito parte das lendas originais dos Aymonidas e, mesmo após ser incluído nelas, a versão hoje conhecida apresenta características de reformulação do personagem idênticas às ocorridas com no Girart de Vienne de Bertrand de Bar-sur-Aube, para torna-lo mais simpático aos ouvintes da Canção.
} 
Ce fait Gaydons, nostre annemis mortex,

Il et ses oncles, dus Naynmes li senez,

Et li Danois, cui Dex puist mal donner!

Cil sont dou roi del tout issi privé

Que ses conseuls ne puet sans euls finer.

Véez lor tentes (toz les confonde Dés!)

Com il sont prez de cel demainne tref.

$(\text { v. 58-64) })^{229}$

A presença das tendas de Gaydon, Naimes e Ogier próximos à do rei marca a importância destes para o seu senhor na condução dos assuntos militares e políticos de interesse do reino. Desse modo, a linhagem de Ganelon se vê excluída das decisões mais importantes, apesar de ser numerosa e rica, acentuando sua tendência para a inveja até o ponto de odiar os outros membros da hoste.

No início deste poema a traição se manifesta, primeiramente, através de acusações mentirosas lançadas pelos Ganelidas contra Gaydon. Reforçando esse procedimento, são realizadas ações dos traidores contra o imperador, no caso a oferta de frutas envenenadas através de um mensageiro orientado a dizer tratar-se de um presente de Thierry. Apesar de Carlos escapar do atentado a desconfiança em relação ao herói havia sido plantada em sua mente, reforçada depois pela acusação por parte do ganelida Thibaut d'Aspremont do herói ter tramado contra a vida do rei $^{230}$. Esse comportamento dos Ganelidas será constante no poema. Gaydon e seus aliados ver-se-ão acusados continuamente de tentarem matar ou destronar o imperador, quando na verdade é a linhagem rival a responsável por todas as conjurações.

Outro método muito usado pelos traidores no decorrer desta Canção é o das emboscadas armadas sem o conhecimento de quem não é da linhagem, visando destruir os adversários dos Ganelidas. Nem o monarca deveria saber dessas ciladas, pois no caso delas fracassarem poder-se-ia lançar a responsabilidade nos angevinos. Para elas terem sucesso a discrição era importante, pois era preciso agir de modo a que o monarca não as descobrisse e, principalmente, tentar impedir a fuga ou a oportunidade de defesa de quem seria atacado. Isso envolvia, ainda, agir com superioridade numérica suficiente para a obtenção da vitória, reduzindo ao mínimo a capacidade de resistência dos adversários. Foi esse o plano quando os Ganelidas atacaram o comboio angevino que abandonava a hoste imperial em direção a Angers, pouco antes do duelo entre Thierry e o ganelida Thibaut

\footnotetext{
${ }^{229}$ GAYDON, p. 3.

${ }^{230}$ Ibid., v. 69-315, p. 3-10.
} 
d'Aspremont $^{231}$. E foi, também, pretensão dos traidores matar através de emboscada ao mensageiro Ferraut, sobrinho de Gaydon, mandado a corte régia para pedir a punição da linhagem adversária e desafiar o rei caso isto não fosse feito ${ }^{232}$.

Um dos episódios do Gaydon, ainda relativo ao jovem Ferraut, envolveu o uso da mentira e da violação da obrigação de hospitalidade, quando o ganelida Hertau atrai o herói para seu castelo, onde pretendia mata-lo ${ }^{233}$. Para fazer isso aproveitou o desconhecimento do angevino de quem ele era e mostrando simpatia ofereceu pousada ao mensageiro, pois isso lhe dava a oportunidade de ataca-lo quando estivesse desarmado. Esse ato violava os preceitos da cavalaria e rebaixava moralmente Hertau, mas isso não o dissuadiu de recorrer à astúcia para destruir um inimigo. A mulher do Ganelida, pensando na honra deste, aconselhou-o a devolver as armas de Ferraut e manda-lo embora, desafiando-o fora das muralhas,

Sire, fait elle, ce iert desloiautez

Si mal le faites, quat harbergié l'avez;

Touz jors seriez mais traïtres clammez.

Mais faitez bien, son harnois li randez,

Metez le à voie, et puis le deffiez;

N'en aurez blasme, sladonques l'ociez.

(v. 4243-4248) $)^{234}$

Esse tipo de argumentação não era capaz de mudar o comportamento dos Ganelidas, uma vez que eles tinham nas ações condenadas pela moral cavaleiresca os meios mais eficazes para sobrepujar seus adversários, estes sim, presos a um código de conduta constrangedor. Como não convenceu seu marido a agir com lealdade, ela e seu filho passaram a apoiar o sobrinho de Gaydon, evitando a sua morte.

A Gesta de Jehan de Lançon mostra Ganelon e seus parentes buscando ininterruptamente a destruição dos doze pares de França. Por se tratar da elite dos cavaleiros de Carlos Magno, se estes guerreiros viessem a ser mortos o imperador não teria condições de defender-se de um complô visando destroná-lo. O envio dos pares como mensageiros à Lançon para intimar Jehan a submeter-se a Carlos abria uma boa possibilidade para isso. No que se refere à execução da missão e ao trato com o inimigo, nos combates ocorridos quando da chegada dos heróis na cidade, os assaltos de Jehan mostraram-se inúteis, devido à habilidade e força dos franceses. Então, o senhor de

\footnotetext{
${ }^{231}$ Ibid., v.1983-2989, p. 61-91.

${ }^{232}$ Ibid., v. 3478-3824, p. 105-116.

${ }^{233}$ Ibid., v. 4139-4687, p.125-141.

${ }^{234}$ Ibid., p. 128.
} 
Lançon pede orientação aos seus conselheiros, sendo o mais ouvido seu parente Alori, um exilado da Corte imperial, o qual sugeriu usar da mentira e da malícia para subjugar os pares. Ofereceu-se hospitalidade aos franceses, além da promessa de submissão por eles exigida, mas apenas com o intuito de atacá-los desarmados. Isso teria sido feito durante a noite, se não fosse a censura de Isoré de Marselha condenando o uso de um procedimento não cavaleiresco e o conselho de agir somente quando os pares estivessem armados e fosse dia, para não se incorrer em desonra. Entretanto, o emprego da mentira continuou na manhã seguinte, com um convite para uma caçada que na verdade terminaria em uma emboscada na qual os franceses seriam sobrepujados pelos seus inimigos em maior número e mortos $^{235}$.

Mas além do exilado Alori, os demais Ganelidas ainda instalados na corte de Carlos Magno teriam um papel importante na ajuda a Jehan de Lançon. O auxílio dessa linhagem visou principalmente a evitar que o imperador reunisse suas tropas e marchasse em socorro dos pares da França. Sabendo da impossibilidade dos franceses resistirem por um longo tempo na cidade de Lançon, Ganelon e seus parentes agem intencionalmente para paralisar os movimentos de seu régio senhor. Assim esperavam dar tempo suficiente para Jehan executar Rolando e seus amigos.

A principal artimanha foi o uso de falsos peregrinos, um grupo de Ganelidas disfarçados de modo a não serem reconhecidos pelos demais membros da corte. Dizendo terem vindo do Santo Sepulcro, afirmaram terem encontrado os doze pares em Roma e estes haviam mandado uma missiva informando da conquista de Lançon e do seu breve retorno a Paris. O plano paralisou a marcha da hoste franca ${ }^{236}$ e isso ofereceu a Jehan a oportunidade e o tempo para tentar destruir os mensageiros franceses através da fome, uma vez eles estarem bloqueados dentro da cidade de Lançon.

Quanto ao personagem Basin, este usa uma série de artifícios, inclusive a mágica e o roubo, para enganar os inimigos dos doze pares e obter vantagens durante a luta. Embora use constantemente disfarces e a mentira, ele não é censurado como um traidor por não mostrar suas reais intenções aos adversários. Como Basin faz parte do grupo de heróis do poema, os seus atos aparecem como habilidades positivas, pois eles garantem a vitória do lado bom, o dos franceses, sobre o lado mau, o de Jehan.

${ }^{235}$ Como já expusemos o Jehan de Lançon, em seu texto do século XIII, não apresenta o início do poema. Tivemos que utilizar a narrativa escrita no século XV para dar uma ideia de como começou a aventura dos doze pares. JEHAN DE LANÇON, Appendice I, p. 163-214.

${ }^{236}$ JEHAN DE LANÇON, v. 1676-1898. 


\section{2- Traição ao monarca}

Verificamos que a traição ao monarca, de forma direta, desenvolveu-se posteriormente à Chanson de Roland. Neste poema o rei era atingido pelo crime devido aos seus principais combatentes, a sua elite guerreira, terem sido massacrados pelos pagãos com a ajuda de um de seus barões, desejoso de vingar-se do que este considerou uma afronta de Rolando.

Embora o termo traïson não tenha sido usado como a nomeação do ato dirigido contra Carlos Magnos, a conduta de Ganelon quando da entrevista com Marsílio e a troca de palavras entre eles, deixam bem claro serem as suas ações prejudiciais ao seu senhor. Quando o rei sarraceno pede informações sobre o imperador cristão e o seu poderio, Ganelon as fornece sem o menor escrúpulo:

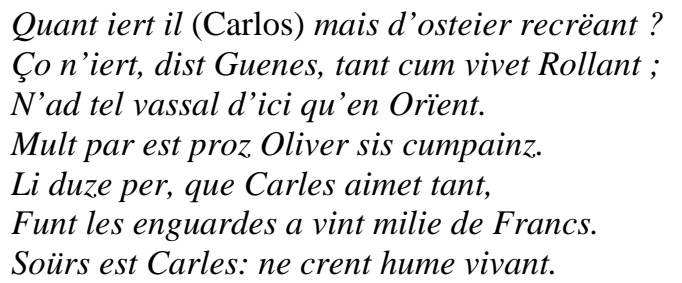
(v. 556-562).

Rolando e os doze pares eram a ponta de lança da hoste francesa e se fossem destruídos Carlos seria derrotado, obrigado a voltar à França e não teria condições de novamente mover guerras na Espanha pagã. Tal ato era uma ajuda clara aos inimigos de seu senhor, agravada pela orientação de como o imperador deveria ser enganado e como poderia ser derrotada em combate à elite guerreira franca:

Bel sire Guenes, dist Marsilies li reis, Jo ai tel gent, plus bele ne verreiz ; Quatre cenz milie chevalers puis aveir. Puis m'en cumbatre a Carle e a Franceis? Guenes respunt: Ne vus a cest feiz! De voz paiens mult grant perte i avreiz. Lessez folie, tenez vos al saveir: L'empereür tant le dunez aveir $N$ 'i ait Franceis ki tot ne s'en merveilt. Par vint hostages que li enveiereiz. En dulce France s'en repairrat li reis. Sa rereguarde lerrat derere sei; Iert i sis niés, li quens Rollant, ço crei; E Oliver Le proz e li curteis. Mort sunt li cunte; së est ki mei em creit, Carles verrat sun grant orguill cadeir, $N$ 'avrat talent que jamais vus guerreit. 
Bel sire Guenes, ço dist li reis Marsilies, Cumfaitement purrai Rollant ocire? Guenes respont: Ço vos sai jo ben dire: Li reis serat as meillors porz de Sizre, Sa rereguarde avrat detrés sei mise; Iert $i$ sis niés, li quens Rollant li riches, E Oliver, en qui il tant si fiet; Vint milie Francs unt en lur cumpaignie. De voz paiens lur enveiez cent milie; Une bataille lur i rendent cil primes. La gent de France iert blecee e blesmie. Ne l' di por ço, des vos iert la martirie. Altre bataille lur livrez de meïsme; De quel que seit, Rollant n'estoertrat mie. Dunc avrez faite gente chevalerie, N'avrez mais guerre en tute vostre vie.

(Laisse 44, v. 580-595)

Chi purreit faire que Rollant i fust mort, Dunc perdreit Carles le destre braz del cors, Si remeindreient les merveilluses oz: N'asemblereit jamais si grant esforz; Tere Major remeindreit en repos.

(Laisse 45, v. 596-600)

O poeta deixou bem claro, nesses versos, a superior capacidade bélica de Carlos Magno como sendo decorrente da presença de Rolando e dos homens ligados a este. Anular este grupo acarretaria a impotência imperial para o cumprimento de sua missão de conquista das terras pagãs e foi esta a expectativa dada pelo traidor a Marsílio. Portanto, não é possível defender ter a traição de Ganelon visado apenas a Rolando e seus companheiros, pois para atingir a estes com o uso das forças sarracenas foi preciso deixar evidente que a morte dos doze pares seria a derrota definitiva do líder dos cristãos, justamente o desejado pelos pagãos. O senhor feudal e rei seria também vitimado pelo ato do barão infiel e o público da Canção teria conhecimento disso desde o início, mas para evitar a punição o criminoso, diante dos franceses, calaria quanto ao seu comportamento na corte de Saragoça.

Quando do julgamento de Ganelon, o cavaleiro Thierry qualificou o crime cometido por aquele como perjúrio, uma violação do juramento de fidelidade ao rei:

Que que Rollant Guenelun forsfesist, Vostre servise l'en doüst bien guarir. Guenes est fels d'iço qu'il le trä̈t, Vers vos s'en est parjurez e malmis. Pur ço le juz a pendre e a murir, E sun cors metre en peine e en exil Si cume fel ki felonie fist.

(v. 3827-33). 
No poema, Carlos movia uma guerra da Cristandade contra o paganismo, uma guerra santa. Os guerreiros convocados para ela estavam ao seu serviço e, portanto, sob sua proteção enquanto demorasse a campanha. Mesmo sentindo-se ofendido, Ganelon não poderia ter agido contra Rolando durante o tempo em que ambos estivessem na hoste real, pois isso atentaria contra o dever do imperador de proteger quem o serve em tempo de guerra. Talvez, se o traidor tivesse feito qualquer coisa contra seu enteado depois do retorno à França, isso poderia ser visto efetivamente como vingança, mas não enquanto estava na Espanha e, como fator agravante, foram utilizados os inimigos de seu senhor e da sua religião para atingir seu objetivo de revanche.

Podemos ter mais evidente a ideia de como Ganelon violou suas obrigações vassálicas se olharmos um documento no qual a fidelidade foi tema e tornou-se muito citado pela clareza como trata o assunto. Em 1020, a pedido do duque Guilherme V da Aquitânia, Fulbert de Chartres escreveu uma missiva na qual definia os deveres do vassalo para com seu senhor. Dela extraímos os elementos mais interessantes para ilustrar não apenas o caso exposto na Chanson de Roland, mas também em outras Canções de Gesta. Fulbert diz existirem seis palavras a serem lembradas pelos vassalos e o que cada uma delas significava:

Incolume, videlicet ne sit domino in damnum de corpore suo. Tutum, ne sit ei in damnum de secreto suo, vel de munitionibus per quas tutus esse potest. Honestum, ne sit ei in damnum de sua iustitia, vel aliis causis, quae ad honestatem eius pertinere videntur. Utile, ne sit ei in damnum de suis possessionibus. Facile vel possibile, ne id bonum, quod dominus suus leviter facere poterat, faciat ei difficile; neve id quod possibile erat, reddat ei impossibile. $^{237}$

Nesse trecho da missiva encontramos as obrigações do vassalo, descritas em tom negativo, que podem ser resumidas em "não atentar contra o corpo do senhor, contre seus castelos, contra seus direitos e seus projetos”. Embora não mencione casos de traição, Fulbert de Chartres completa seu pensamento dizendo, após falar sobre o senhor, "sicut ille, si in eorum praevaricatione vel faciendo consentiendo deprehensus fuerit, perfidus et perjurus"

237 "São e salvo, para que não cause qualquer prejuízo ao corpo de seu senhor. Seguro para que não prejudique o seu senhor divulgando os seus segredos ou os castelos que garantem a sua segurança. Honesto, para que não prejudique os direitos de justiça do seu senhor ou outras prerrogativas que interessem a honra a que pode pretender. Útil para que não cause prejuízo aos bens do seu senhor. Fácil e possível, para que não torne difícil ao seu senhor o bem que este poderia facilmente fazer e para que não torne impossível o que teria sido possível ao seu senhor". Apud GANSHOF, F.-L. Que é o Feudalismo? Lisboa: Europa-América, 1976, p. 113-114. 
("tal como o vassalo que fosse visto faltar aos seus deveres, pela acção ou por simples consentimento, seria ele culpado de perfídia e perjúrio") ${ }^{238}$, ou seja, não cumprir as promessas estabelecidas pela vassalagem levavam à condenação do seu violador.

Ganelon desrespeitou vários dos itens citados pelo bispo de Chartres. Disse a Marsílio de onde vinha a força ofensiva de Carlos Magno, da presença dos doze pares e dos vinte mil franceses na sua vanguarda, e isso ameaçava o seu poder e a sua segurança. Atentou contra o direito e a honra de seu senhor, ao procurar infringir-lhe uma derrota militar. Também tornou impossível algo possível ao seu rei, a conquista de Saragoça e de toda a Espanha. Violados os princípios mais importantes das relações de fidelidade vassalo-senhor, mesmo não sendo nomeado traidor para com o imperador, Ganelon tacitamente o era. E se em nenhum momento o barão infiel apresentou a proposta de ferir ou matar Carlos, ao enfraquecer a hoste franca, ele permitia essa possibilidade ao criar a expectativa dos sarracenos avançarem mais para o norte, invadindo as terras cristãs. Para Fulbert, o vassalo ao incorrer nessas faltas tornava-se perjurus ao seu senhor, do mesmo modo que na acusação feita por Thierry Ganelon "s'en est perjurez" frente ao imperador.

Passando para a Canção Girart de Vienne, existem poucos discursos a fazer do herói um traidor do rei, feitos por Rolando diante de Olivier, antes dos dois se tornarem companheiros e tais afirmações podiam soar mais como uma provocação do que uma acusação $^{239}$. Bertrand de Bar-sur-Aube, obviamente, faz disso uma alegação falsa, rebatida pelo comportamento respeitoso de Girart para com seu senhor. Neste poema temos um primeiro exemplo na literatura épica de que lutar contra o rei não poderia ser visto como uma traição se tivesse havido uma falta qualquer do senhor, como a negação de justiça ou um abuso de poder prejudicial ao vassalo. Como a relação vassálica era contratual e tinha caráter sinalagmático, qualquer das partes poderia romper o acordo se a outra não cumprisse as obrigações dela esperadas.

O poema Renaut de Montauban, por seu lado, apresenta uma série de problemas diferentes, embora pareça seguir a ideia trabalhada por Bertrand. Talvez o mais complexo seja a dupla falta de Bueves de Aygremont, ao não responder a chamado para a hoste real para combater os pagãos da Saxônia e, depois, matar o filho do imperador, enviado para intima-lo a comparecer na corte e justificar-se perante Carlos Magno. Apesar do poeta fazer elogios a Bueves, ele não abafa definitivamente a censura a este pela sua violência e desrespeito para com seu senhor vassálico. Que a relação senhor-vassalo existia fica

\footnotetext{
${ }^{238}$ Ibid., p. 114.

${ }^{239}$ GIRARD DE VIENNE, v. 5194 e 5625.
} 
evidente por uma resposta dada a Carlos por um dos irmãos do barão de Aygremont, Aymon de Dordonne.

S'il vos fait tort de rien, si soit guerredoné,
Qu'il est vos liges hon, si vos doit feelté:
De vos doit il tenir trestote s'erité
Et porter vos doit foi et tote loiauté.
Et ce poise moi mult qu'a qu'a li estes meslé.

(v. 835-839)

$\mathrm{Na}$ condição de homem lígio do imperador era seu dever apresentar-se quando convocada a hoste e, também, respeitar os mensageiros enviados pela corte de Paris, ainda mais sendo um dos membros da embaixada o próprio filho de seu senhor. Bueves violou essas obrigações, terminou morto em uma emboscada dos Ganelidas e seus parentes não puderam vingar-se do imperador, sendo derrotados em batalha. Se nos lembrarmos de que uma batalha na Idade Média era vista como um julgamento de Deus e, portanto, travada apenas em último caso pelos adversários em guerra ${ }^{240}$, a derrota dos irmãos de Bueves foi a confirmação deste ter agido de forma condenável, não havendo opção à linhagem além de aceitar um acordo com o imperador, conforme externou Fouque, um sobrinho de Girart de Roussillon:

\footnotetext{
Quer oiez mon conseil qui vos dirai briement, A vos et a mon oncle qui voi ci en present: Acordons nos a Karles au fier contenement Et devenon si home, jel vos lo loiaument, Et pardonon la mort vostre frere briment, Ou, se atendez Karles jusqu'a l'ajornement, Sachiez de verité nos i perdron forment, Quer il sont plus de nos .xxx.m. et .vii.c.
}

Conformar-se com a derrota implicava em abandonar o direito a vingança e, de certa forma, no reconhecimento de que um parente agira mal.

Existe um poema ligado à Gesta de Renaut de Montauban, no qual se tentou dar uma justificativa para o não comparecimento de Bueves de Aygremont na hoste contra os saxões. Trata-se do Vivien de Monbranc ${ }^{241}$, do século XIII, e nele o herói Vivien é filho de Bueves e irmão de Maugis, sendo ainda um almançor convertido ao cristianismo. Por conta disto é cercado em Monbranc pelos pagãos e seu pai e seu irmão vão à Paris pedir a ajuda de Carlos Magno. Como este se recusa a marchar, ambos o desafiam:

${ }^{240}$ BOURIN-DERRUAU, Monique. Temps d'équilibres, temps de ruptures: XIIIe siècle. Paris: Seuil, 1990, p. 152-157. DUBY. Le dimanche de Bouvines, p. 190-200.

${ }^{241}$ VIVIEN DE MONBRANC. Chanson de geste du XIIIe siècle. Editée par Wolfgang VAN EMDEN. Genève : Droz, 1987. 
Puis que vous me failliez, vostre hommage vous rent:

Ne tendroi mes de vous de terre plain .i. gant

(v. 323-24),

e partem da corte perseguidos por Lotário. Se fosse levado em conta esse episódio, Bueves não teria obrigação de juntar-se ao exército imperial e nem de comparecer à corte régia. $\mathrm{O}$ senhor não havia cumprido com suas obrigações vassálicas, não defendera seus homens. Por conta disso Bueves procedeu ao diffidatio, ao desafio, rompendo os laços com Carlos e arguindo para si o amparo do direito feudo-vassálico ${ }^{242}$. Entretanto, não existe nenhuma menção nos textos dos manuscritos Douce e La Vallière do poema Renaut de Montauban sobre esse episódio, nem mesmo nos discursos de Bueves ao saber do envio dos mensageiros reais e nos quais ele faz ameaças ao imperador. Se o barão nada diz a respeito desse rompimento, isto leva a pensar na existência dos laços vassalicos quando da chamada da hoste e da partida da embaixada fatídica, ao menos nesses dois manuscritos.

Em compensação temos mais uma incongruência nesse poema, a menção em algumas oportunidades de um episódio excluído da narrativa, o da morte de Luís, outro filho de Carlos Magno, pelas mãos de Ricardinho, o mais jovem dos Aymonidas:

Richart será detrait a coe de somier, Qu'il ocist Loeÿs a l'espee d'acier,

Et Renaut Bertelai le preuz d'un eschequier.

Quant je les adoubai mult fis que mal senez, Puis ocistrent mon filz,donc je suis adolez.

(v. 2998-99)

Tal homicídio teria ocorrido na mesma festa na qual Reinaldo matara Bertolai, o sobrinho do imperador e estaria ligado à aventura em Montessor, nas Ardennes. Nessa ocasião, para a paz ser feita, a intimação imperial ao chefe do grupo era "Envoie li ton frere Richart que tant as chier, / Li rois li fera pendre ou tot vif escorchier" (v. 2494-95). Escolher apenas um dos irmãos para ser supliciado e a execução sendo degradante, marcariam a ocorrência de um crime gravíssimo perante o senhor. Supomos ter o poeta descartado esse episódio pelo peso negativo que o mesmo teria para os filhos de Aymon, maculados por derramar o sangue de um membro da família real e apto à sucessão ao trono. Se Bueves de Aygremont não escapou da morte, isto talvez se devesse à ideia dele ter cometido um ato

${ }^{242}$ BLOCH, Marc. Les formes de la rupture de l'hommage dans l'ancien droit féodal. In: Mélanges historiques. Paris: Serge Fleury; Éditions de l'EHESS, T-I, 1983, p.189-206. GANSHOF. Qu'est-ce que la féodalité?, p. 156-160. 
imperdoável ao matar Lotário. Excluir o episódio do homicídio de Luís mantinha as mãos dos Aymonidas limpas do sangue de um herdeiro de seu senhor e não criava uma situação embaraçosa para quando fosse feita a paz com o imperador, no final do poema.

As tentativas de mostrar Reinaldo de Montauban e Maugis de Aygremont como traidores ao rei, assim como no caso de Girart de Vienne, decorrem das acusações do imperador, o qual se sente prejudicado pelas ações desses heróis. Para provar isso o rei chega a tomar para si o procedimento que precedia o duelo judicial, algo inadmissível por causa da sua condição de chefe supremo da Cristandade épica:

Renaut, dist Karllemaigne, je ne vos puis amer. Je vous ferai ardoir ou les menbres couper. Par mon chief, dist Ogier, ne l'oserez penser! Ogier, dist Karllemaigne qui se prist a irer, Volez donc vos vers moi mon traïtor tenser? Sire, ce dist Renaut, qui l'oseroit mostrer Que je fusse traïtre? - Je! dist Karle li ber. Renaut done gaje sanz plus de demorer.

(v. 10708-10715)

Sire, ce dist Renaut, a moi en entendez. A cui me combatrai? Por Deu, ne me celez. A moi, ce li dist Karlles, qui vos ci veez.

(v. 10727-10729)

Atitudes impensadas ou movidas pelo ódio e desejo de vingança, levando o imperador a abusar de seu poder e esquecer ser a sua função manter a paz e distribuir a justiça, justificavam no poema os fracassos de Carlos diante de seus jovens adversários. Do lado oposto, Reinaldo considerava-se em erro com relação a Carlos Magno por lutar contra este e ansiava pelo perdão régio ${ }^{243}$. Esse comportamento era mostrado pelo poeta como indicativo da inexistência de traição por parte do senhor de Montauban e os bons conselheiros do rei aparecem com o mesmo entendimento, incentivando um acordo de paz com os Aymonidas no qual estes seriam perdoados e reintroduzidos na corte.

Por outro lado, os Ganelidas são identificados como traidores no decorrer da narrativa devido aos maus conselhos dados por eles a Carlos Magno. Não se tratava apenas de agradar ao monarca defendendo o seu ponto de vista, pois por trás desse apoio havia o interesse material movendo a parentela de Ganelon, pois a continuidade da guerra mantinha a proximidade do clã junto ao rei. Estar perto deste e oferecer-lhe sustentação garantia recompensas aos Ganelidas, enquanto as mesmas eram negadas aos defensores do fim do conflito. Por conta disso a má linhagem incentivava as ações belicosas de Carlos

${ }^{243}$ BOUTET, Dominique. Les chansons de geste et l'affermissement du pouvoir royal (1100-1250). Annales $E S C, 1982$, n $^{\circ} 1$, p. $10-12$. 
apesar de estas serem prejudiciais ao reino e à Cristandade. O clã dos traidores incentivou a emboscada contra Bueves de Aygremont e ofereceu os guerreiros para executa-la, às escondidas do resto da corte. Foram ainda a principal força de ataque aos Aymonidas em Vaucoulours. Outro problema criado pelos maus conselheiros era o de afastar o imperador de suas obrigações básicas, que eram garantir a paz nas terras sob seu governo e distribuir justiça aos homens colocados sob o seu poder, conforme proposto pelos preceitos do chamado "agostinismo político", corrente nos séculos XII-XIII para justificar o poder dos reis na terra ${ }^{244}$. Preso ao desejo de vingança Carlos esquecia-se de seus deveres e os Ganelidas esforçavam-se para levar seu senhor a continuar nesse esquecimento.

A existência de obrigações conflitantes gerou uma situação problemática para o personagem Ogier o Dinamarquês, na Gesta Renaut de Montauban, pois ele oscila entre a fidelidade devida ao rei e aquela decorrente dos laços familiares, pois ele era primo dos Aymonidas. Obrigado por juramento a levar seus homens para a emboscada de Vaucoulours, Ogier recusou-se a combater desde o início da luta, mas foi obrigado a isso depois de desafiado por Reinaldo, nos estágios finais da batalha. Para Maugis ele se comportara como um traidor e desonrava seus parentes ao participar daquela emboscada ${ }^{245}$. Ao retornar para o acampamento imperial, Rolando o acusou de trair o rei e permitir a fuga dos filhos de Aymon ${ }^{246}$. Apesar disso, Carlos não levou tal acusação para julgamento e nem, no resto do poema, considerou o Dinamarquês como responsável por tal crime, embora Ogier deixasse clara sua simpatia pelos de Montauban.

O choque entre os deveres do vassalo e do sangue era algo possível na França medieval, por conta de irmãos e primos servirem a senhores diferentes e, em algumas ocasiões, inimigos. Uma das dificuldades da monarquia capetíngia para estender o seu poder foi com relação às linhagens suficientemente fortes e solidárias, capazes de travar as

${ }^{244}$ BOUTET, Dominique. La politique et l'histoire dans les chansons de geste. Annales ESC, 1976, $\mathrm{n}^{\circ}$ 6, p. 1124-1125.

${ }^{245}$ Quando Maugis chega para socorrer os Aymonidas, ataca primeiramente Ogier e faz o seguinte discurso:

Par Deu, sire Daneis, grant marveille en avon Que venistes traïr les .iiii. fiz Aymon: Vos fustes del lignage Girart de Rosillon Et Doon de Nantuil et Bueves de Aygremont, Onques vostre lignage ne pensa traïson! Quant vos estes traïtre, cuer avez de felon! (v. 7718-23)

${ }^{246}$ RENAUT DE MONTAUBAN, v. 7988-8014. 
ações do rei ${ }^{247}$. Outro problema decorria da preferência pelo princípio da primogenitura para transmissão dos bens territoriais e honoríficos. Quando um vassalo ou mesmo senhor territorial tinha vários filhos e não podia dotá-los todos com algum lote de terras, com alguma renda ou alguma prebenda eclesiástica, a opção para os irmãos mais novos era a busca de um senhor que os sustentasse. Tal procura poderia conduzi-los às cortes capazes de se tornarem inimigas da linhagem desses cavaleiros devido aos constantes conflitos decorrentes das disputas entre o rei capetíngio da França e seu poderoso vassalo Plantageneta, nos séculos XII e XIII. Na batalha de Bouvines (1214), guerreiros do lado rebelde enfrentaram membros de sua própria família que permaneciam fiéis à realeza e estavam presentes na hoste real francesa ${ }^{248}$. Quando exércitos se encontravam para combater, cada cavaleiro podia reconhecer algum parente ou amigo do lado oposto do campo $^{249}$.

No poema Gaydon a traição impera com os complôs ganelidas contra o rei, visando usurpar a coroa. Um de seus procedimentos foi acusar falsamente o herói do poema de tentar envenenar Carlos Magno. Ao fazer isso eles conseguem distorcer a visão do rei na avaliação do justo e do injusto, tornando o monarca obcecado no desejo de vingança contra Thierry. Novamente os Ganelidas desviam o imperador do cumprimento correto de suas funções, pois ao invés de fazer justiça a seus homens, Carlos comporta-se de forma injusta e intransigente, mesmo depois de um duelo judicial apontar a culpa da parentela de Ganelon.

Ao difamarem a imagem do bom vassalo diante do rei, os Ganelidas podiam avançar seu plano principal, uma conspiração visando destronar Carlos Magno. Para fazerem isso consideraram necessário eliminar o imperador, daí recorrerem frequentemente ao envenenamento. O uso de venenos não é muito comum nas Canções de Gesta, sendo citada no fragmento do poema Mainet ${ }^{250}$, narrativa sobre a infância de Carlos, para explicar a morte de Pepino o Breve e de Berta dos Pés Grandes, pais do imperador, pelos filhos tidos por Pepino com a serva Aliste. Na Canção Gaydon o veneno torna-se uma arma recorrente no desenvolver da narrativa e não é usada apenas contra Carlos, pois

\footnotetext{
${ }^{247}$ BARTHÉLEMY, Dominique. L'État contre le "Lignage": un thème a développer dans l'histoire des pouvoirs en France aux XIe, XIIe et XIIIe siècles. Médiévales, n 10, 1986, p. 37-50.

${ }^{248}$ DUBY. Le dimanche de Bouvines, p. 58, referindo-se a Hugo de Boves.

${ }^{249}$ Ibid., p. 217.

${ }^{250}$ MAINET, fragments d'une chanson de geste du XIIe siècle. Par Gaston PARIS. Romania, T-IV, 1875, p. 305-337.
} 
outros personagens são vítimas dela, inclusive membros da má linhagem ${ }^{251}$. Outra ação ganelida contra o rei foi a tentativa de sequestra-lo para depois assassina-lo, nos versos finais do poema ${ }^{252}$. Apoderar-se do corpo de seu senhor para fazer-lhe mal era visto como traição, especialmente por ser um dos primeiros juramentos feitos quando da criação de laços vassálicos o de não se atentar contra o corpo e os membros daquele a quem se promete fidelidade ${ }^{253}$.

A linhagem traidora faz uso de maus conselhos para levar seu senhor a agir de acordo com os seus interesses. Por vezes seus pedidos ou orientações vêm acompanhados de algum presente, em especial ouro, pois Carlos é representado no poema como avaro e senil. Após a vitória de Gaydon sobre Thibaut d'Aspremont no ordálio, em troca de duas mulas carregadas de riquezas o imperador liberta os prisioneiros Ganelidas, reféns ou violadores do duelo judicial ${ }^{254}$. Convertidos nos principais conselheiros da corte, os Ganelidas empregam todos os meios para enganar seu senhor, exigindo a punição de inocentes. Para isso assumiam o papel de vítimas quando suas armadilhas contra os heróis falhavam, jogando a culpa pelos incidentes sobre os seus adversários. Como têm certeza de encontrar os ouvidos do imperador favoráveis a eles, os Ganelidas conseguem fazer com que o este perca sua iniciativa para conduzir o reino. Tudo isso é conduzido sem a má linhagem perder de vista a conspiração visando derrubar o rei, substituindo-o por algum de seus membros.

Presos aos seus interesses pessoais e linhageiros, a parentela de Ganelon prejudicava o seu senhor e o império cristão. Movidos pela cobiça eles levavam outros barões à penúria ou prejudicavam os seus direitos, como no caso do castelão impedido de caçar pelas maquinações da linhagem criminosa ${ }^{255}$. Por não fazer nada contra esse tipo de mazela, o imperador poderia estar sendo conduzido ao pecado, pois após a sua morte responderia perante Deus sobre seus maus passos e negligências. Uma preocupação dos bons conselheiros deveria ser com a salvação do corpo e da alma de seu senhor. Os Ganelidas estavam preocupados apenas em garantir o desaparecimento do rei para poder suceder-lhe no trono.

\footnotetext{
${ }^{251}$ Carlos Magno é alvo do veneno nas páginas 3-9 (v. 69-259) e 110 (v. 3639-47); o jovem provençal que levou as frutas envenenadas ao imperador morre ao comer uma que lhe foi oferecida por Alori, p. 7 (v. 208 221); os ganelidas Guinemant e Humbalt são acusados de matar os pais envenenados, nas páginas 159 (v. 5258-78) e 209 (v.6919-23).

${ }^{252}$ GAYDON, p. 318-320 (v. 10572-10642).

253 GANSHOF, Op. cit., p. 136-139, além do exemplo da missiva de Fulbert de Chartres, p. $135-136$.

${ }^{254}$ GAYDON, p. 60 (v. 1949-77).

${ }^{255}$ Ibid., p. 119-120 (v. 3934-68).
} 
Na Gesta Jehan de Lançon, novamente estão presentes os complôs movidos pela linhagem de Ganelon contra Carlos Magno, agora em favor de um inimigo "estrangeiro" do imperador. Seguindo a versão do século XV, na qual consta o início do poema, verificamos que Jehan já havia combatido o imperador ${ }^{256}$. No manuscrito do século XIII o clã ganelida permanece na corte de Paris, apesar de Jehan ser um dos seus membros e aproveita a condição de independência deste, bem como sua riqueza, para conspirar contra o rei. A conspiração visava substituir Carlos por um membro da sua linhagem e o primeiro candidato era justamente Ganelon, o qual ansiava exercer esse poder:

Que je vos rendrai [a Carlos] pris au seignieur de Lanson,

Encor serei ge rois, qui qu'en poit ne qui non,

Et tenrai riche cort a Rains ou a Loon

Ne ja n'avrai o moi se tous traïtres non.

(v. 1655-58).

Por esse motivo eles agem de modo a retardar a partida da hoste de socorro aos doze pares, tentam recrutar cavaleiros para o senhor de Lançon, dão informações aos inimigos do rei para estes terem vantagens na luta. Um dos informes dados por Ganelon permitiria a captura de Carlos durante uma caçada ${ }^{257}$. Não apenas o traidor tenta tornar impossível a vitória de seu senhor, mas também põe em risco a integridade física deste ao permitir seu aprisionamento, novamente violando os princípios contidos na missiva de Fulbert de Chartres. Esta captura não visaria a obtenção de condições razoáveis para um acordo de paz, como ocorre nos poemas Girart de Vienne, Renaut de Montauban e Gaydon, e tencionava apenas destronar Carlos em favor de um membro da má linhagem.

Para os Ganelidas deste poema, o dever para com a linhagem era superior à fidelidade devida ao rei. O interesse principal do clã é ampliar seu poder, não importa se para isso fosse necessário ir contra os interesses do monarca e do reino. Apesar desse comportamento a linhagem não é banida da corte e das terras cristãs embora existam motivos para essa punição: maus conselhos, mentiras tentando impedir o socorro aos doze pares, conluio com Jehan para derrotar as forças imperiais. Talvez o não banimento se deva ao fato do Jehan de Lançon não ser uma Canção de Gesta de fundo histórico e sim uma criação baseada na apropriação e na adaptação de episódios de outros poemas épicos. Por conta disso, Ganelon e seus parentes deveriam continuar junto aos franceses para mais tarde cometer o seu maior crime, provocando o desastre de Roncesvales.

\footnotetext{
${ }^{256}$ JEHAN DE LANÇON, Appendice I, v. 61-70.

${ }^{257}$ Ibid., v. 3643-3747.
} 


\section{3- Canções de Gesta e Coutumiers}

Nas Canções de Gesta a traição apresenta certas características que são repetidas em diversos poemas. Constituem lugares comuns adotados pelo poeta para deixar bem clara a identificação dos personagens negativos de sua narrativa, mostrando o quanto eles eram inassimiláveis por uma sociedade cavaleiresca idealizada e o quão perigosos eram esses elementos para seu senhor, para o resto da corte, para o reino/império e para a própria Cristandade.

Inicialmente a traição é mostrada como um ato contra qualquer indivíduo do grupo cavaleiresco, não precisando haver uma relação hierárquica entre os envolvidos. O crime é apresentado principalmente como seguindo uma tendência horizontal, pois o traído e o traidor eram do mesmo grupo social e possuiam semelhantes poder e riqueza. Rolando, Thierry, Reinaldo e seus irmãos, os doze pares de França são cavaleiros originários de linhagens hierárquica e materialmente equiparadas ao clã ganelida. Se há diferenças entre eles, elas decorrem da proximidade com o monarca, distribuidor de benesses e de justiça dentro do reino. Rolando está mais próximo de Carlos Magno do que Ganelon; Gaydon, antes de ter sido injustamente acusado, também tinha essa posição ao contrário dos Ganelidas. Os doze pares, como guerreiros de elite do exército franco, também gozavam de um favor especial do imperador. Mas isso não significava que um membro de outra linhagem, não próxima da corte, não viesse a ser beneficiada pelo rei por seus serviços. Carlos prometera recompensar Ganelon quando este retornou de Saragoça ${ }^{258}$.

O traidor é motivado, na poesia épica, pelo ódio ou pela inveja daqueles cujo sucesso ou favoritismo diante do senhor comum é mais evidente. O ódio pode vir de uma disputa ou desentendimento antigo, tal como a vitória de Thierry sobre Pinabel na Chanson de Roland, influenciou o poema Gaydon e o ódio que lhe votaram os Ganelidas. Ele também pode surgir do sentimento de ter sido destratado em público, como Ganelon ao ser escolhido por seu enteado como mensageiro junto aos pagãos. A inveja conduz os cortesãos insatisfeitos a urdir alguma trama para a destruição dos heróis, como fazem os conselheiros do rei Yon, intimando este a trair os Aymonidas, tendo em vista serem estrangeiros muito beneficiados pelo seu senhor em detrimento dos demais barões da Gasconha.

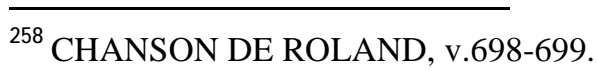


A traição era algo planejado individual ou coletivamente. Como o Ganelon do Roland, um cavaleiro sozinho poderia executar algum ato para destruir um desafeto, sem envolver o resto de sua parentela. Entretanto, devemos reconhecer tratar-se de uma situação rara na poesia épica. O mais comum era um grupo ou uma linhagem inteira estar envolvido com alguma forma de conspiração contra um concorrente ou contra o monarca. Nas Gestas Renaut de Montauban, Gaydon e Jehan de Lançon, os membros da linhagem de Ganelon reúnem-se frequentemente para planejar algum golpe para prejudicar seus inimigos. A responsabilidade da parentela na realização de ações condenáveis era uma forma de mostrar como a solidariedade ao clã se apresentava como superior aos indivíduos e o quanto estes deviam aparecer, na literatura medieval, como manifestações humanas do caráter de sua família. $\mathrm{O}$ sangue conduzia à traição, na visão dos poemas épicos posteriores a 1180, e esse motivo determinava o destino dos diversos personagens de uma Canção.

Para um plano traiçoeiro ter sucesso, o segredo era fundamental e os poetas e jograis trabalhavam constantemente com esse princípio. Trair envolvia a dissimulação, pois quem não estivesse envolvido no plano não poderia saber o que se intentava. Daí o mostrar certa fisionomia falaciosa ao rei e aos outros cavaleiros escondendo as verdadeiras intenções sob uma máscara de solicitude e respeito fraudulentos em alguns episódios, rapidamente denunciados pelo poeta ao explicar para seu público as reais intenções dos traidores, isso quando não havia a antecipação do alerta quanto a má ação a ser praticada. Isso era válido para os Ganelidas, mas estendia-se a Herves de Lausanne, a Yon da Gasconha, não ligados àquela linhagem e, todavia, dissimulados quando tencionaram levar os Aymonidas à perdição.

Outra característica levantada sobre a traição é o de ser um ato tramado às escondidas, envolvendo um pequeno grupo de pessoas. Quando Ganelon chegou a Saragoça, primeiro comportou-se como um mensageiro exemplar, sendo ameaçado de morte por Marsílio e pelo filho deste ${ }^{259}$. Mas nesse momento ele estava diante de todos os barões e cavaleiros pagãos da cidade, reunidos em uma grande assembléia para ouvi-lo. Somente quando o rei sarraceno e alguns de seus conselheiros mais próximos levaram Ganelon para um vergel, um lugar bem discreto, é que a traição começou a ser tratada e planejada ou, como diz o poeta, "La purparolent la trä̈sun senz dreit" (v. 511). Do mesmo modo, Renaut de Montauban a decisão de trair os Aymonidas foi tomada por um

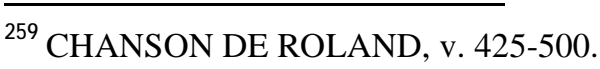


grupo restrito de conselheiros, seis no total, reunidos junto a Yon e não em uma corte para a qual todos os vassalos gascões tivessem sido chamados a opinar ${ }^{260}$. Gaydon também vai nesse sentido, pois são constantes os encontros de um seleto grupo de Ganelidas para planejar as formas de destruir o herói e o seu monarca. Somente os barões mais importantes ou cuja imoralidade é mais exacerbada participavam das reuniões, feitas estas com discrição e longe das vistas da maioria dos membros da hoste, inclusive de boa parte da própria linhagem ganelida, como no primeiro episódio de tentativa de envenenamento do imperador, onde Thibaut d'Aspremont é incisivo com seu senescal, alegando um malestar:

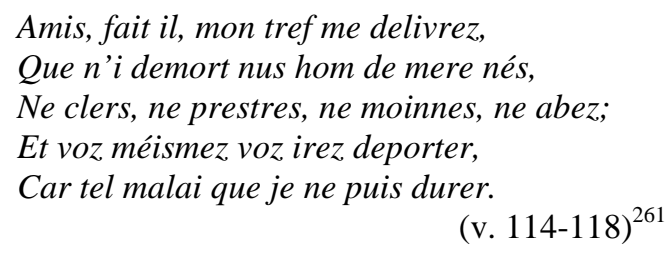

É possível fazer um paralelo com a obra de Galbert de Bruges, na qual é narrado o assassinato de Carlos o Bom, duque de Flandres. A linhagem dos Erembaut, segundo o autor, reuniu-se discretamente em determinadas moradias, inclusive à noite, para evitar que pessoas alheias aos seus projetos soubessem de seus planos homicidas ${ }^{262}$. Graças ao segredo, puderam aproximar-se de seu senhor e matá-lo junto com alguns conselheiros.

Se o sucesso de uma traição depende de não ser descoberta antecipadamente, o comportamento dos envolvidos nela pode obrigar a simulação de uma falsa amizade ou, ao menos, passar para as demais pessoas uma imagem favorável dos conjurados. Fingir-se amigo ou aliado de quem se pretende trair cria a vantagem da aproximação e com isso aumentam as chances do plano funcionar. Foi desse modo que agiu Herves de Lausanne para poder penetrar em Montessor e dominar os Aymonidas. Yon da Gasconha procedeu de modo a não demonstrar ter aceitado entregar Reinaldo e seus irmãos a Carlos Magno, reafirmando de forma enfática - e mentirosa - nunca ter atentado contra o direito de alguém ou buscado o seu mal:

Renaut, me mescrois tu, di, cuvert renoiez, Que de noient te voille traïr ne engignnier? Ainc ne boisai nul home le monte d'un denier!

(v. 6736-38)

\footnotetext{
${ }^{260}$ RENAUT DE MONTAUBAN, v. 5668-6198.

${ }^{261}$ GAYDON, p. 4.

${ }^{262}$ GALBERT DE BRUGES. Histoire du meurtre ..., p. 18-20. The Murder ..., p. 108-111.
} 
Graças a esse comportamento, no qual o vassalo (Reinaldo) se vê obrigado a respeitar a palavra de seu senhor (Yon), os filhos de Aymon partem ingenuamente ao encontro da emboscada. Trair nas Canções de Gesta envolve, primeiramente, a busca da destruição de um adversário, levando-o à morte. Para isso ocorrer, tomam-se medidas visando conduzilo ao local onde seria emboscado, sem a vítima saber o que a aguarda. Toma-se ainda a precaução de colocar o traído em desvantagem em relação aos seus atacantes, quer seja devido a uma grande desvantagem numérica ou por estarem armados de modo inconveniente para a situação enfrentada.

Mas também a traição pode limitar-se a fazer o indivíduo ou grupo prejudicado ser rejeitado pelo seu senhor. No caso da poesia épica, isso envolvia afastar os bons conselheiros e cavaleiros da presença de Carlos Magno, sendo eles substituídos, principalmente, por representantes da linhagem Ganelida. Longe da corte ou da boavontade do monarca, perdia-se a oportunidade de receber boas recompensas, de ganhar presentes valiosos nas festas, de obter novos feudos ou funções áulicas rentáveis, de ser agraciado com a mão de uma rica herdeira. Uma corte era um ambiente de competição constante entre os diversos homens que a compõem, particularmente entre os cavaleiros ainda solteiros e não beneficiados com algum bem enfeudado ou casamento. A maledicência podia estar muito difundida nesse meio onde quem adquirisse uma posição favorável passava a ser atacado pelos concorrentes.

Passemos agora à traição em relação ao monarca. De início ela pode consistir numa conspiração para derrubá-lo. No caso da poesia épica os Ganelidas são tidos como os responsáveis pelos planos visando destronar Carlos Magno. Se Bertrand de Bar-surAube não mostra essa característica ao dividir os ciclos da Matéria Carolíngia, ela se apresenta bem desenvolvida no poema Fierabras, onde os parentes de Ganelon vêem na morte do imperador a oportunidade deles tomarem o reino para si, bastando abandonar a hoste durante a batalha por Maltrible ${ }^{263}$. Se Renaut de Montauban não apresenta nenhum episódio no qual tenha havido alguma trama para deposição de Carlos, apesar do comportamento deste ser contrário àquele esperado de um rei cristão, mesmo a

${ }^{263}$ FIERABRAS, v. 5118-5156. Neste poema o próprio Ganelon não aceita a ideia de abandonar Carlos Magno à morte, destoando o seu comportamento do de sua parentela:

Ne Plache Dex, dist Guenes, qui en croiz fu penez, Ke ja en tel maniere soit mis sires tuez. Mex woil avoir la teste et les membres coupez. Que mon poier n'en fache, ja n'en serai blamez. (v. 5158-61). 
possibilidade de sua renúncia voluntária é inaceitável para os barões, os quais são conduzidos ao desespero diante de tal possibilidade ${ }^{264}$. Foi o próprio imperador quem lembrou a todos, em um de seus discursos, as conspirações movidas contra ele ${ }^{265}$. A primeira, quando ele era ainda jovem, urdida pelos seus meios-irmãos, obrigando-o a fugir para a Espanha ${ }^{266}$. Outra tentativa fora feita na época de cingir a coroa e orquestrada pelos doze pares de então ${ }^{267}$. Entretanto, é na Gesta Gaydon que encontramos as citações mais frequentes sobre um golpe ganelida contra Carlos e sobre as diversas tentativas feitas, de início com o uso de veneno para se conseguir a morte do imperador e, posteriormente, por meio do sequestro do monarca, para mata-lo longe da hoste.

Todavia, não era preciso ambicionar o trono para se cometer traição. $O$ ato de bajular o rei quando este estava errado, com o intuito de se obter vantagens para si ou para a linhagem também podia ser visto, nos poemas, como uma forma de trair o senhor. Quando o rei se mostrava fraco ou insistia em comportar-se de forma contrária ao exigido pelo seu magistério, caberia aos conselheiros reconduzi-lo ao bom caminho. Os Ganelidas agem de forma a acentuar os erros do monarca e, no Gaydon, comportavam-se de uma forma diabólica e sedutora, de modo que o velho Carlos Magno não conseguia enxergar o perigo à sua frente, representado pelo desejo regicida desses cortesãos.

Outra consequência dos maus conselhos da corte era levar o monarca a esquecer de suas obrigações de garantir a paz no reino e distribuir justiça para seus súditos. Com isso o rei entrava em desacordo com a justificativa divina para sua existência e começava a beirar a tirania. Ao fazer isso, ele punha em risco a própria salvação de sua alma, pois se na terra nenhum homem podia puni-lo por seus erros, segundo os princípios do agostinismo político, corrente nos séculos XII e XIII, Deus o julgaria e condenaria no Além.

Os Coutumiers analisados durante nossas pesquisas apresentam alguns elementos idênticos à poesia épica. Talvez isso não deva surpreender, pois é reconhecido por muitos estudiosos que as Canções de Gesta trazem em suas narrativas muitos elementos jurídicos relativos às relações feudo-vassálicas e, também, manifestam uma tendência para tratar temas políticos caros à aristocracia cavaleiresca de língua francesa, tanto a continental quanto a insular inglesa ${ }^{268}$. Léon Gautier já havia demonstrado isso em um artigo de

\footnotetext{
${ }^{264}$ RENAUT DE MONTAUBAN, v. 10215-10290.

${ }^{265}$ Ibid., v. 9355-9373.

${ }^{266}$ Desta história existe o fragmento do poema conhecido como Mainet, editado por G. Paris.

${ }^{267}$ Um testemunho sobre a existência deste poema perdido existe na Karlamagnus Saga norueguesa. SAGA DE CHARLEMAGNE, p. 61-97.

${ }^{268}$ BOUTET. La politique et l'histoire dans les chansons de geste, p. 1119-20 ; 1124-25.
} 
$1869^{269}$, mas os trabalhos de Dominique Boutet e de François Suard colocaram essa característica em relevo nos últimos decênios. Quanto aos diversos textos legais usados para orientar os juristas das diversas autoridades locais francesas, eles foram escritos para atender uma necessidade regional e do senhor daquele território, não à monarquia capetíngia. Mesmo o chamado Établissements de Saint Louis constituía um apanhado dos costumes das regiões de Orleans e de Paris, mas não emanaram da corte régia.

Um primeiro ponto levantado nos Coutumiers é o de uma visão da traição como crime abrangente. É cometido contra qualquer membro da sociedade e a definição dada nos Coutumes de Beauvais é o melhor exemplo dessa amplidão:

826. Traïsons si est quant l'en ne moustre pas semblant de haine e l'em het mortelment si que, par la haine l'en tue ou fet tuer, ou bat ou fet batre dusques a afoleure celui qu'il het par traïson.

827. Nus murtres n'est sans traïson, mes traïson puet bien estre sans murtre en mout de cas; car murtres n'est pas sans mort d'homme, mes trä̈sons est pour batre ou pour afoler en trives ou en asseurement ou en aguet apensé ou pour porter faus tesmoing pour celi metre a mort, ou pour li deseriter, ou pour li fere banir, ou pour li fere hair de son seigneur lige, ou pour mout d'autres cas semblables. ${ }^{270}$

Nessa relação feita pelo bailio encontramos vários exemplos expressos nas Canções de Gesta: a dissimulação do ódio, a busca da morte do outro sem dar-lhe oportunidade de defesa, o falso testemunho ou a tentativa de indispor um senhor contra um bom vassalo. Nos Établissements, quando se orienta como deveriam ser feitos os discursos de acusação e de defesa numa corte de justiça, procura-se dar exemplos claros da falta cometida pormenorizando o ato que deveria ser julgado ${ }^{271}$.

Com muita frequência os Coutumiers fazem uma associação da traição com o assassinato (murdre/murtre), crime também definido por Felipe de Beaumanoir:

825. Murtres si est quant aucuns tue ou fet tuer autrui en aguet apensé puis soleil esconsant dusques a soleil levant, ou quant il tue ou fet tuer en trives ou en asseurement. ${ }^{272}$

\footnotetext{
${ }^{269}$ GAUTIER.. Op. cit., 1869, p. 79-114.

${ }^{270}$ PHILIPPE DE BEAUMANOIR, p. 430.

${ }^{271}$ ÉTABLISSEMENTS DE SAINT LOUIS, T-II, Livre I, Chap. CLXXI - D'apeler home de murtre et de traïson, p. 314-316. Livre II, Chap. XII - De apeler home de murtre et de trä̈son, p. 357-360

${ }^{272}$ PHILIPPE DE BEAUMANOIR, p. 429-430.
} 
Ambos ocorrem de forma idêntica, baseando-se em um ataque dirigido a alguém sem este ter condições de defender-se, reagir ou fugir da agressão. A dissimulação entra como elemento principal, pois não se demonstra o ódio homicida para com aquele a quem se deseja matar, até o momento de assassina-lo.

Mas, como Beaumanoir deixou claro, não é preciso haver morte para a traição se manifestar. Toda ação prejudicial a alguém na qual foi usada a mentira, a calúnia, a dissimulação ou a má-fé podia ser assim qualificada. E como dissemos anteriormente, o ambiente das cortes régias e senhoriais era de competição extrema entre um elevado número de candidatos a propriedades feudais, herdeiras ricas ou presentes, conscientes do limitado estoque de "bens" a serem oferecidos como prêmio. Assim só os melhores ou os mais hábeis ou os mais astutos podiam conseguir uma recompensa cobiçada. Caluniar um concorrente, fazer este cair em desgraça frente ao senhor comum, era uma das táticas para obter-se vantagem nessa competição. E a legislação medieval tinha conhecimento desse tipo de procedimento condenável.

$\mathrm{Na}$ leitura de determinados parágrafos dos Coutumiers encontramos várias situações consideradas traição e que poderiam ser levadas à julgamento em uma corte de justiça. Obviamente eles partem da premissa da sobrevivência do agredido e da sua presença para fazer a acusação. Os atos condenados tem relação com a quebra da paz firmada entre dois grupos contendores, a violação dos salvo-condutos concedidos durante o trânsito de determinados elementos numa região, o desrespeito aos compromissos assumidos entre duas linhagens relativas a matrimônio ou compensação de algum dano.

Feitos para orientar os responsáveis pela aplicação das leis em uma determinada região, esses textos não costumavam falar dos atos dirigidos contra o rei e sim contra os grandes senhores de terra. Assim a violação da paz do senhor em determinado território, o desrespeito às obrigações vassálicas, a recusa do vassalo em comparecer à corte ou em responder a uma convocação do senhor imediato eram condenáveis ${ }^{273}$. Inclui-se nessa relação o aprisionar o senhor ${ }^{274}$ e a morte deste às mãos de um de seus homens. A pena para esses casos era a perda dos bens ou, dependendo da gravidade da falta, a morte.

Há, portanto, uma proximidade entre o entendimento destes documentos voltados à orientação dos tribunais com as representações da traição ou das traições nas Canções de Gesta. Para agradar o seu público cavaleiresco, a poesia épica deveria apresentar em suas

\footnotetext{
${ }^{273}$ COUTUMIERS DE NORMANDIE. Tome II: La Summa de legibus Normannie in curia laicali, p.180190.

${ }^{274}$ ÉTABLISSEMENTS DE SAINT LOUIS, T-II, p. 74-75.
} 
narrativas situações conhecidas e valorizadas por ele. As questões ligadas ao direito e à justiça eram importantes, especialmente numa época na qual a realeza aumentava o seu poder político e material, ameaçando os privilégios antes detidos de forma incontestável pelos diversos senhores territoriais franceses. 


\section{4- OS QUE LUTAM CONTRA O REI}

Dos poemas escolhidos para nosso trabalho quatro se referem a vassalos em luta contra o monarca: Girart de Vienne, Renaut de Montauban, Gaydon e Jehan de Lançonapesar deste último não aparecer efetivamente como vassalo de Carlos Magno. O fato de conduzirem um conflito armado desafiando o poder de seu senhor ou daquele visto como o líder da Cristandade não macula a imagem da maioria desses barões e cavaleiros. No final do século XII e na primeira metade do século XIII ocorre, pelo contrário, uma valorização dos que contestavam o poder régio quando este deixava de cumprir com as obrigações, estas ligadas a uma determinada forma de visão do exercício do ministério monárquico baseado no chamado "agostinismo político"275. Esses personagens épicos não são descritos como traidores e, em vez disso, são representados como exemplos de lealdade e devoção ao rei. Essa situação contraditória é tratada neste capítulo.

\section{1- Entender quem são os vassalos em conflito com o rei}

Uma primeira observação deve ser feita em relação à impropriedade da qualificação "vassalo rebelde" para designar Girart de Vienne, os Aymonidas e Gaydon nos poemas onde são narradas suas histórias, assim como em toda e qualquer outra Canção onde se apresentem personagens nas mesmas situações destes heróis. Em nenhum desses textos a expressão "vassalo rebelde" ou apenas a palavra "rebelde" é usada para designá-los e, também, não as encontramos em outros poemas enquadrados como pertencentes ao Ciclo de Doon de Mayence.

Talvez o primeiro motivo para isso ocorrer é que dentro da tradição judaico-cristã os termos "revolta" e "rebelde" eram associados à rebelião de Lúcifer contra Deus. Levado pelo orgulho e pela vanglória esse anjo, tido como o mais belo e inteligente do mundo celeste, seduziu e levou outros anjos a se oporem à Divindade. Derrotados, foram todos precipitados do céu e privados da presença de Deus ${ }^{276}$, mas, apesar disso, não

\footnotetext{
${ }^{275}$ ARQUILLIÈRE. Op. cit.

${ }^{276}$ Essa era a interpretação dada pelos Padres da Igreja para o Livro de Isaías, 14:12-14, cuja versão latina se apresenta assim: Quomodo cecidisti de caelo, / Lucifer, qui mane oriebaris? / Curruist in terram, / Qui vulnerabas gentes? / Qui dicebas in corde tuo: / In caelum conscendam, / Super astra Dei / Exaltabo solium
} 
desistiram de afrontar seu antigo Senhor e Lúcifer continuou a tentar destruir as obras divinas, em especial o Homem. A revolta contra o poder constituído por Deus na terra enquadra-se no pecado capital do orgulho e, portanto, não podia ser encarado de forma positiva pelos cristãos do medievo ${ }^{277}$. Esses termos foram tornados correntes a partir do século XIX, quando as Canções começaram a ser estudadas e agrupadas de acordo com suas temáticas particulares. Tornadas correntes desde então elas permanecem em uso até os dias atuais.

Aqueles que foram chamados de "Rebeldes" pelos estudiosos da épica medieval francesa $^{278}$, não atentavam contra a ordem estabelecida na terra e nem contra o poder detido pelo monarca. Eles não desejam destronar Carlos Magno, privá-lo de parte de seu império ou constituir um reino oposto ao dele. Os barões em confronto buscavam uma satisfação da justiça real diante de uma afronta feita contra eles e, na impossibilidade de consegui-la, direcionavam sua fúria contra algum membro da corte ou algum parente do rei, nunca visavam diretamente a este. Depois disso, fugiam e limitavam-se a se defender dos ataques lançados por um imperador obcecado pelo desejo de castigá-los e de vingar-se dos atos hostis realizados em seu prejuízo.

O denominado Ciclo de Doon de Mayence engloba as Canções nas quais cavaleiros e barões estão em luta contra seu senhor e rei, mas os diversos personagens descritos nos poemas acabavam sendo divididos entre aqueles vitimados por uma injustiça imperial, os chamados "rebeldes" 279 , e os verdadeiros traidores, cujas ações eram conscientemente direcionadas a prejudicar ou depor o monarca. O próprio Doon, de quem se tirou o designativo do Ciclo, tem um poema próprio, mas composto apenas no século XIII. Portanto tratou-se de uma narrativa tardia cujo autor tentava mostrar seu personagem-título como tendo um caráter positivo, cuidado necessário, pois havia um Doon de Mayence traidor e sem escrúpulos citado em uma narrativa de fins do século XII, a meio termo entre

meum; / Sedebo in monte testamenti, / In lateribus aquilonis; / Ascendam super altitudinem nubium, / Similis ero Altissimo?

277 CASAGRANDE, Carla; VECCHIO, Silvana. Histoire des péchés capitaux au Moyen Age. Paris: Aubier, 2003, p. 19-44.

${ }^{278}$ GAUTIER, L. Les épopées françaises, T-III, 1880, p. 95, referente ao poema Girart de Vienne ; p. 719, para o Huon de Bordeaux.

${ }^{279}$ Empregaremos a palavra "rebelde" (entre aspas) por tratar-se de um termo cômodo para designar quem está em luta contra o monarca. Mas temos consciência de que ele é impróprio para adjetivar os heróis da maioria dos poemas com esse tema. 
a Canção de Gesta e a Canção de Aventuras, o Beuve de Hamptone ${ }^{280}$. Em pelo menos duas oportunidades o poeta marca a diferença dos dois personagens no Doon de Mayence:

On m'apele Doon de Maience la grant;

Mes chen n'est pas Maience dont chantent li auquant,

Qui est près de Hantonne outre la mer flotant, Ains siet jouste le Rim, une eve moult bruiant, Par decoste Alemaigne, où sunt li Alemant.

Et si rot maint Doon à Maience jadis. Chil Do dont je vous chant,qui chest fet a empris Contre le roi Kallon et qui s'est aatis, Chen ne fu pas chil Do, le traïtre faillis, Que Beuvon de Hantonne cacha de son païs, Le mari Josiane, la bien feite au cler vis. Ains est li anchien et li premerain vis Dont la geste sailli des barons de haut pris, Qui ont sus Sarrazins le bon resne conquis

Apesar dessa preocupação, Doon de Mayence tornou-se para a poesia épica francesa dos séculos XIV-XV e para as suas adaptações franco-italianas não apenas o chefe de uma linhagem condenável, como também um dos principais responsáveis por deserdar os heróis dessas narrativas.

Outro poema do século XIII, o Gaufrey, é favorável a Doon e o encontramos como o pai de doze rapazes: Gaufrey (pai de Ogier o Dinamarquês), Doon de Nanteuil (pai de Garnier), Grifon (pai de Ganelon), Aymon (pai de Reinaldo de Montauban), Bueves de Aygremont (pai de Maugis), Oto (pai de Yvon e Yvoire), Ripeu (pai de Anseis) e Sevin (pai de Huon de Bordeaux), Peron (ancestral de Godofredo de Bouillon, herói da Cruzada de 1095-1099), Morant de Riviers (pai de Raimundo de Saint-Gilles, outro herói da primeira Cruzada), Hernaut de Gironda e Girart de Roussillon. Quase todos esses personagens ou os filhos destes aparecem em narrativas nas quais combatem Carlos Magno (Ogier, Doon e Garnier de Nanteuil, os Aymonidas, Maugis e seu pai, Huon de Bordeaux, Girart de Roussillon) ${ }^{282}$. Observa-se, entretanto, serem onze deles apresentados como leais e dignos. Mas Grifon de Autefoille é representado de forma negativa e, no decorrer da narrativa, mostra-se capaz até de abandonar o pai nas mãos dos sarracenos. Como genitor

\footnotetext{
${ }^{280}$ BEUVE DE HAMPTONE. Chanson de geste anglo-normande de la fin du XIIe siècle. Édition bilingue. Publication, traduction, présentation et notes par Jean-Pierre MARTIN. Paris : Honoré Champion, 2014.

${ }^{281}$ DOON DE MAYENCE, p. 97 e 201, além das explicações do editor, no Prefácio, p. i-iii.

${ }^{282}$ GAUFREY, chanson de geste. Publiée pour la première fois d'après le manuscrit unique de Montpellier par MM. F. GUESSARD et P. CHABAILLE. Paris : Vieweg, 1859, v. 80-119, p. 4-5.
} 
de Ganelon, portanto, dele se origina a linhagem responsável pelo desastre de Roncesvales, lembrado quando de sua apresentação, nos versos 86-88:

Et le tiers des enfans si ot à non Grifon;

Chil fu pere fel Guenes qui fist la trä̈son

Dont moururent à glesve li .XII. compengnon. ${ }^{283}$

Essa linhagem também estaria implicada em todas as crises que ameaçaram a integridade do reino franco e a vida do próprio imperador. A opção do autor por doze filhos pode estar associada à tentativa de criar um paralelo entre esses cavaleiros e os doze apóstolos. Como estes, a prole de Doon iria expandir a fé cristã, mas através das armas e da conquista das terras pagãs e não pela pregação. E como no caso dos apóstolos um dos seus membros não apresentaria o mesmo caráter dos demais, sendo capaz de colocar a perder todos os esforços de expansão da Cristandade.

Possivelmente antes do final do século XII havia poemas nos quais se cantavam as histórias de barões em luta contra os monarcas carolíngios e esses vassalos eram apresentados como os responsáveis pela guerra por seu orgulho e pela desobediência ao seu senhor. A partir de cerca de 1180 os jograis e poetas começam a rever esse motivo e o Girart de Vienne de Bertrand de Bar-sur-Aube aparece como um caso emblemático, pois há indícios de poemas anteriores desfavoráveis a Girart contrapondo-se ao texto escrito por Bertrand.

Na Saga de Charlemagne norueguesa e na Chronique Rimée de Philippe Mousket encontramos um Girart de Vienne sem disposição de servir ao imperador e recusando reconhecer ter recebido suas terras como vassalo do rei. Nesses resumos que se serviram de versões da narrativa anteriores a 1180 a revolta do vassalo não tem justificativa alguma. Na Saga Carlos entrega Vienne a Girart porque o pai deste o servira com lealdade ${ }^{284}$. Mas o herdeiro começa a prejudicar seu senhor, recusa-se a comparecer em sua corte e alega não dever homenagem ao rei por seus domínios ${ }^{285}$. Esse comportamento leva o imperador a reunir seu exército e a cercar Vienne. Já na Chronique Rimée, Girart fora convocado à corte real e negou-se a comparecer, dizendo ainda " $Q u$ 'il n'el siervi ne sierviroit, / Mais le sien francement tenroit" (v. 4508-09) ${ }^{286}$, negando a existência de laços vassálicos de subordinação a Carlos. Em ambas as fontes o barão orgulhoso foi obrigado a pedir a paz ao rei.

${ }^{283}$ Ibid., p. 4.

${ }^{284}$ SAGA DE CHARLEMAGNE, Chap. XXXIV-XXXV, p. 106-108.

${ }^{285}$ Ibid.. Chap. XXXVIII, p. 112-113.

${ }^{286}$ PHILIPPE MOUSKES. Chronique rimée, p.181. 
Fica claro nos dois resumos a censura ao vassalo por não cumprir os deveres de auxilio e conselho ao seu senhor. Ao negar a existência dessas obrigações deixara, portanto, de ter direito às terras recebidas como feudo para a realização de suas obrigações vassálicas. O senhor/rei tinha o direito de mover-lhe guerra, cabendo ao vassalo reconhecer seu erro e se colocar à mercê do rei. Carlos não era movido por impulsos de vingança e nem negara algo a seu "homem" e sim este cometera uma falta contra o imperador.

Na versão de Bertrand de Bar-sur-Aube trabalhou-se para tornar a "revolta" justificada, pois em nenhum momento, segundo o poeta, Girart deixara de cumprir com seus deveres. Ao invés disso, havia a má-vontade da parte do imperador em recompensar os filhos de Garin de Monglane, apesar de estes o servirem com lealdade e realizarem diversas campanhas em seu nome ${ }^{287}$. Renier só recebe Genebra após ameaçar abandonar a corte, sendo apoiado em suas reclamações pelos demais conselheiros de $\operatorname{Carlos}^{288}$. E Girart é investido de Vienne porque seu senhor lhe havia prometido a duquesa da Borgonha como esposa, mas depois decidiu toma-la para si, prejudicando o seu servidor. Apesar de ofendido, este não desafiou ou ameaçou o imperador e todos os demais membros da corte insistiram na concessão de uma compensação justa pela quebra da palavra régia $^{289}$.

No poema, o vassalo continuou mantendo sua fidelidade, até ser vítima de uma afronta, não de seu senhor, mas da rainha. Estava escuro quando Carlos cedeu Vienne como feudo a Girart e este foi beijar o pé de seu senhor, já deitado no seu leito; a rainha colocou o pé dela diante do rosto do barão e este o beijou ${ }^{290}$. Como ninguém tinha visto, não haveria consequências para esse ato, mas a rainha resolveu, anos depois, vangloriar-se disso diante de Aymeri, o sobrinho de Girart. O rapaz e, depois, toda a sua linhagem, viu nisso uma forma de desonra gravíssima. Quando o senhor de Vienne foi exigir compensação com base em seu direito de vingança, e isso significava pedir a cabeça da rainha, ele encontrou um Carlos Magno intratável e não disposto a atender a vontade de

${ }^{287}$ GIRART DE VIENNE, v. 835-881. É interessante nesses versos Renier combater especificamente os ladrões de caminhos que infestavam os domínios do rei. Se a presença de salteadores era uma constante em todas as regiões da Cristandade, também podemos nos lembrar das lutas movidas por Luís o Gordo, antes e depois de sua coroação, contra os castelões salteadores instalados em suas terras ou nas das igrejas sob sua proteção.

${ }^{288}$ Ibid., v. 935-1186.

${ }^{289}$ Ibid., v. 1200-1458.

${ }^{290}$ Ibid., v. 1459-1476. 
seu "homem",291. Essa injustiça da parte do rei abriu a possibilidade do rompimento da fidelidade vassálica, e o barão prejudicado não perdeu tempo para mover atos hostis contra o seu senhor, atacando e saqueando a cidade de Mâcon.

Apesar do longo conflito que se seguiu, com o cerco de Vienne, o comportamento dos barões e cavaleiros "rebeldes" permaneceu respeitoso para com o rei. Durante um dos combates Girart golpeia o próprio Carlos Magno. Envergonhado desce do cavalo e vai abraçar as pernas do imperador, pedindo perdão pela ousadia ${ }^{292}$. Esse procedimento tornase um passo literário corrente em poemas posteriores, onde o tema é a luta entre um barão e o rei. A poesia épica não admitiu a morte do senhor, especialmente em se tratando do monarca, pelas mãos do vassalo, mesmo quando aquele abusava de seu poder na tentativa de derrotar o "rebelde".

Outro ponto trabalhado por Bertrand e tornado comum nos posteriores poemas de "revolta" foi a continuidade do conflito como decorrente da obstinação do rei em perseguir seu oponente, do desejo de puni-lo, mesmo que isso se mostrasse difícil de realizar e um acordo se apresentasse como mais vantajoso para as duas partes. Através de Olivier, Girart tenta obter a paz com Carlos, oferecendo-se para servir a este em Paris e reconhecendo a sua condição de vassalo do rei ${ }^{293}$. Tal procedimento resguardaria a dignidade do barão e de sua linhagem, pois seria uma submissão sem desonra. Entretanto, o desejo do imperador - e ele deixa claro isso - é a humilhação de seu oponente, algo inaceitável para esse grupo familiar cioso de sua honra:

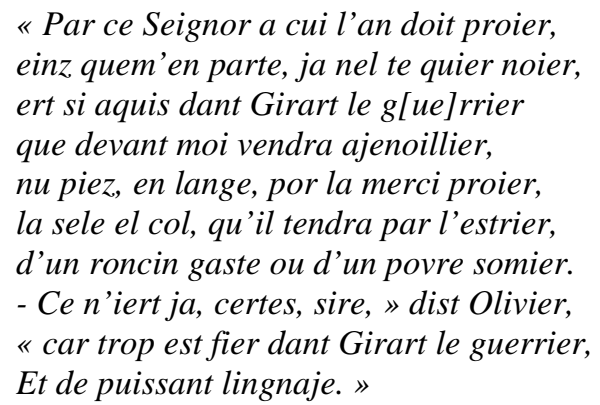

(v. 4025-4034)

Enquanto o rei se mantivesse irascível, a guerra continuaria sem vencedor e sem vencido, apenas desgastando as forças da Cristandade e fazendo desta uma presa fácil para os sarracenos, como o final do poema mostraria.

\footnotetext{
${ }^{291}$ Ibid., v. 1821-2288.

292 Ibid., v. 4413-4455.

293 Ibid., v. 3971-4034. É interessante notar que o motivo gerador do conflito, a afronta da rainha, simplesmente desaparece do poema após o início do cerco de Vienne.
} 
Do lado dos vassalos levados a combater seu senhor, estes se mostravam dispostos a submeter-se ao rei, desde que sua honra como cavaleiros e barões fosse preservada. Demonstravam isso quando tinham a oportunidade de capturar Carlos Magno, após este ter se perdido durante uma caçada e cair numa emboscada preparada pelos de Vienne. Todavia esses "rebeldes" preferem renunciar a todo ato lesivo física e moralmente ao seu senhor, mostrar humildade diante deste e implorar o perdão régio, não como os penitentes derrotados descritos nos versos acima, mas como guerreiros ainda em armas voluntariamente colocados numa posição de humilde e respeitosa reverência ${ }^{294}$.

A narrativa do poema Renaut de Montauban apresenta outra dinâmica, com um monarca muito diferente daquele encontrado no Girart de Vienne. No poema dos filhos de Aymon o rei constantemente comete atos censuráveis perante os seus vassalos e não admite qualquer contestação aos seus desejos e às suas ordens. Isso só deixa como opção aos jovens "rebeldes" continuar indefinidamente a luta, enquanto para os barões da hoste as alternativas ficam restritas a cumprir a contragosto as ordens do imperador, consideradas por eles como injustas, ou negar-se a isso e serem vítimas do furor régio.

O início do conflito com os Aymonidas decorreu de uma negação de justiça pelo monarca à Reinaldo, seguida de uma agressão, verbal ou física, de Carlos contra o jovem. Durante uma partida de xadrez Bertolai, sobrinho do imperador, agredira a Reinaldo e este foi ao seu senhor pedir uma indenização. Entretanto, quando pediu a compensação, ao invés de limitar-se ao ocorrido na corte, ele a relacionou à morte de seu tio Bueves de Aygremont, assassinado em uma emboscada com assentimento do rei ${ }^{295}$. Aquela festa realizada na corte era para celebrar a paz recentemente feita entre o monarca e os parentes de Bueves, que derrotados em batalha aceitaram perdoar Carlos pelo assassinato de seu membro. Aymon de Dordogne e seus filhos não haviam se apresentado à hoste levantada por Girart de Roussillon e Doon de Nanteuil para vingar a morte do senhor de Aygremont. Quando os acordos para cessar o conflito foram feitos, ainda no campo de batalha, eles também não estavam presentes e não participaram das promessas de perdão a Carlos ${ }^{296}$. Por nada ter prometido, Reinaldo se sentiu no direito de exigir uma indenização pela morte de seu tio, mas não era essa a visão do resto de seu clã e ele e os irmãos acabaram banidos das terras de seu pai e não encontraram refúgio nos domínios de nenhum de seus parentes,

\footnotetext{
${ }^{294}$ Ibid., v. 6358-6480.

${ }^{295}$ RENAUT DE MONTAUBAN, v. 2156-2199.

${ }^{296}$ Ibid., v. 2057-2142.
} 
sendo obrigados a construir a fortaleza de Montessor, um castelo "bastardo", ou seja, ilegal por não ter sido autorizado por qualquer representante do poder territorial.

Boa parte das ações dirigidas contra os Aymonidas é apresentada no poema como de responsabilidade dos Ganelidas. Eles constituiram uma parte considerável das forças imperiais usadas na emboscada de Vaucoulours, nas assembleias eram os defensores da continuidade do conflito, espionavam os outros barões para poder denunciá-los ao rei, caso se mostrassem simpáticos aos Aymonidas. No manuscrito La Valière ${ }^{297}$, quando Rolando comanda a retirada das hostes francas cansadas de lutar inutilmente contra Reinaldo e fartos da intransigência do rei, apenas a linhagem de Ganelon permaneceu no acampamento imperial. Conforme diz um mensageiro enviado a Reinaldo, agora em Tremoine (Dortmund),

Rollans s'est correchiés, si em devint molt noir; De Charlon s'est partis por vostre amor avoir, O li li.XII. per, cez pues apercevoir. Veez com il s'en vont, ces tentes font chaoir. N'i a gaires haut home qui tiegne haut menoir, Ne s'en voit par corroz,por vostre amor avoir, Fors Guenelon lo conte; cil ne s'an volt movoir, Ne nus de son lignage; vez les tantes seoir. (v. 15079-15086).

O interesse da linhagem traidora na guerra implica no seu afastamento das outras parentelas francas, principalmente porque os outros clãs parecem ter laços de sangue com os filhos de Aymon. Mesmo após ter sido feita a paz entre os Aymonidas e Carlos Magno e depois do cumprimento da penitência pelo herói principal do poema, os Ganelidas ainda perturbaram a corte forjando falsas acusações contra Reinaldo para poderem ferir os filhos deste $^{298}$. Por conta dessa conduta hostil da família de Ganelon, boa parte das ações bélicas e represálias dos cavaleiros "rebeldes" são dirigidas contra essa linhagem e não necessariamente contra o imperador.

Fazer de outros personagens o alvo de represálias permite aos heróis da narrativa manter o respeito ao rei, especialmente ao serem iniciados os episódios que compõem a "fase gascã" do poema, quando os Aymonidas já estão instalados no reino da Gasconha, a serviço de Yon e possuem o controle de Montauban. Entretanto, o texto apresenta muitas variações quanto a forma desse respeito, pois do episódio do cerco de Montessor até o da corrida de cavalos em Paris, Reinaldo se portara de forma intransigente na sua hostilidade

\footnotetext{
${ }^{297}$ CHANSON DES QUATRE FILS AYMON, p. 761-762.

${ }^{298}$ RENAUT DE MONTAUBAN, v. 13564-13643.
} 
contra o imperador e nem mostrou-se disposto a um acordo de paz. Mas quando a hoste francesa invade a Gasconha o desejo de perdão e o caráter respeitoso do herói para com seu imperador tornam-se mais fortes. Isso afeta muito pouco os outros filhos de Aymon, especialmente Ricardinho, partidário do confronto e até da eliminação física do rei ${ }^{299}$, enquanto Aalard e Guiscardo aceitam as decisões de Reinaldo. Nesse caso podemos pensar numa diferenciação de comportamento decorrente da posição de Reinaldo e de Ricardinho na hierarquia feudo-vassalica. O primeiro aparece como senhor inconteste de Montauban, é casado com a irmã de Yon e tem filhos, assumindo assim a posição de senior, o mais velho e líder do grupo. Seu irmão mais novo não tem as responsabilidades decorrentes da condição de um dominus em um elo intermediário da cadeia feudal, nem é responsável pela direção de um feudo com o comando de outros homens, mas ao mesmo tempo um vassalo obrigado a servir um superior. Ricardinho é, portanto, um iuvenes e como não tinha obrigações, além da fidelidade aos irmãos e o dever, ao qual se juntava o prazer, de combater, podia ter arroubos irresponsáveis, logo contrariados pelas decisões mais ponderadas de seu irmão mais velho ${ }^{300}$.

Outra característica dos Aymonidas, em especial de Reinaldo, é a busca constante do perdão imperial. Assim, quando do resgate de Ricardinho, o herói troca golpes com Carlos sem reconhecê-lo e ao perceber quem era seu oponente diz,

Hé! Diex, ce dist le ber, qui me feïstes nez, Cist norri mon lignage et tot mon parentez: Le poing devroie perdre donc je l'ai adesez! (v. 9974-9976).

Depois se ajoelha e pede perdão ao rei, se não para ele, ao menos para os irmãos. Mais tarde, com o imperador desarmado em Montauban, Reinaldo repete suas propostas, mas não consegue a misericórdia do monarca e deixa-o partir ${ }^{301}$. O herói encara o conflito com Carlos como algo contra a natureza dos laços que os unem, pois fora o imperador quem o armara cavaleiro e aos seus irmãos, dera-lhes montarias, inclusive o seu cavalo maravilhoso Bayart ${ }^{302}$. O texto deixa entrever, ainda, serem os filhos de Aymon sobrinhos do imperador, pois ainda no início da narrativa este "Mult par aime Renaut filz sa seror

${ }^{299}$ Ibid., v. 9885-9919: após ser salvo da forca, Ricardinho veste a armadura de Ripeu de Ripemont, provoca Carlos Magno e ambos combatem a cavalo e a pé; v. 11045-11050: com o imperador capturado em Montauban, Ricardinho jura mata-lo, se Renaut concordar.

${ }^{300}$ DUBY, Georges.. Les “jeunes” dans la société aristocratique dans la France du Nord-Ouest au XIIe siècle. In : ___ Féodalité. Paris : Gallimard, 1996, p. 1383-1397. Esse estudo ainda valia para no início do século XIII, quando a versão Douce do Renaut de Montauban foi escrita.

${ }^{301}$ RENAUT DE MONTAUBAN, v. 11001-11182.

${ }^{302}$ Ibid., v. 840-929. 
germaine" (v. 935), e esse parentesco aumenta a gravidade da discórdia entre eles. Os bons conselheiros, como Naimes da Baviera, procuram restabelecer a paz, pois reconhecem ser melhor dispor do serviço desses duros guerreiros de Montauban do que continuar uma guerra desgastante da qual não se espera a vitória. Os laços de sangue entre muitos barões e os Aymonidas também incentivam a busca de um acordo para por fim ao conflito e protegem os jovens quando estes estão em perigo.

O respeito pelos laços vassálicos assumidos era outra característica dos filhos de Aymon, obviamente influenciados pelo secundogênito ${ }^{303}$. Assim, a crença de Reinaldo que o rei Yon, por ser o seu senhor, estava falando a verdade sobre a possibilidade de ser perdoado por Carlos facilitou o envio dos quatro rapazes para a armadilha imperial em Vaucoulours. E vencido este perigo, Reinaldo insistiu na necessidade de resgatar das mãos de Rolando o seu senhor, mesmo tendo este se comportado de modo infiel para com seu vassalo, pois não houvera desafio formal (diffidatio) e, portanto, os laços de fidelidade ainda estariam valendo na concepção do herói. Esse comportamento, descrito pelo poeta, fazia desse Aymonida um exemplo para os cavaleiros que constituíam o público principal da Canção de Gesta. Esta, no século XIII, assim como outras formas literárias, tomara uma forma moralizante, ensinava quem a ouvia ser cantada ou declamada quais as formas corretas e erradas de agir e, esperava-se, que o ouvinte colocasse em prática os bons ensinamentos $^{304}$.

O caráter íntegro dos Aymonidas é marcado, finalmente, por sua submissão à vontade final do rei, visando conseguir a paz definitiva e o retorno à corte de Paris. Mas o acordo com o imperador só foi possível após os jovens terem conseguido uma vantagem militar e moral muito superior à capacidade de revide de seus inimigos. Isso se deveu ao aprisionamento de Ricardo da Normandia, após um combate perto de Tremoine, e do filho do imperador, o jovem Carlinhos, sequestrado por Maugis ${ }^{305}$. Diante da possibilidade de ver os dois prisioneiros enforcados, o rei aceitou fazer a paz, mas ao ver salvo seu barão e seu herdeiro, voltara atrás em sua promessa. Somente a ameaça da partida dos doze pares e da maior parte da hoste, convenceu Carlos a aquiescer em por fim da guerra e perdoar seus inimigos. Entretanto é ele quem coloca os termos do acordo, apesar de Reinaldo já os ter propostos anteriormente, e estes não são fáceis. O cavalo encantado Bayard é jogado

\footnotetext{
303 Dos filhos de Aymon, o primogênito é Aalard, e tem o papel de conselheiro; Renaut é o segundo e destaca-se pela estatura alta, superior à dos outros homens; Guiscardo é o terceiro e muito discreto; Ricardinho, o mais novo é o mais agressivo dos rapazes.

${ }^{304}$ BOURIN-DERRUAU, Op. cit. p. 26.

${ }^{305}$ Esta é a versão do manuscrito Douce, v. 12580-12802. Na versão do manuscrito La Valière apenas Ricardo da Normandia é capturado pelos Aymonidas.
} 
no Reno para morrer afogado, mas ele consegue salvar-se e foge para a floresta de Ardennes. Reinaldo, por sua vez, é obrigado a fazer uma peregrinação ao Santo Sepulcro para purgar os seus pecados e os de seus irmãos. Somente quando voltasse seria aceito na corte de Paris.

Se a guerra foi prolongada, desgastante e humilhante para Carlos Magno isso ocorreu apenas devido à intransigência imperial, não por vontade dos "rebeldes". O rei aferrara-se ao desejo de vingança, colocando isso como o seu único objetivo e fechando os olhos para suas obrigações como monarca cristão. Ao invés da paz, ele incentivara o conflito. Ao invés de fazer justiça, ele continuamente a violou. Somente quando sentiu estar perdendo o reino ao qual devia governar, Carlos desistiu da luta e aceitou por em prática uma virtude esperada de quem exercia o magistério régio, a misericórdia.

Ao lermos o poema Gaydon encontramos uma situação totalmente desfavorável a Carlos Magno, cujas características principais eram, aqui, a ingratidão a quem o servira fielmente e uma senilidade que o tornava cego perante os acontecimentos ao seu redor. Thierry prestara serviços importantes ao rei, sendo o principal deles o desmascarar Ganelon e sua traição, arriscando a própria vida no duelo judicial contra Pinabel. Entretanto Carlos passa a persegui-lo, crente na história de ter o jovem planejado a sua morte, quando na verdade isso era obra dos parentes de Ganelon. Mesmo a vitória de Gaydon em um duelo com Thibaut d'Aspremont, o verdadeiro conspirador e preparador de venenos contra o rei, levou este a rever suas desconfianças ${ }^{306}$. E como se não bastasse, o imperador faz dos Ganelidas seus principais conselheiros, em detrimento de Naimes ou Ogier, simpáticos a Gaydon. Parte disso deve-se à cobiça e à avareza do monarca, incentivadas pelo ouro oferecido continuamente pela linhagem traidora.

Aqui a luta entre senhor e vassalo decorre da incapacidade de Carlos em cumprir suas obrigações como rei. Ele não consegue manter a paz no reino, não faz justiça aos seus homens e nem protege seus súditos dos abusos cometidos pelos maus barões de sua corte. O imperador se mantém alienado do que ocorre nas terras sob sua proteção. As manifestações divinas em seu favor não lhe vêm diretamente trazida por entes celestes, como ocorria na Chanson de Roland. Os sonhos premonitórios estão ausentes, assim como os anjos protetores. No final da narrativa é Gaydon quem recebe o enviado celeste

\footnotetext{
${ }^{306}$ GAYDON, v. 85-105, 122-130, 210-221 (p. 3-8), referentes ao veneno de Thibaut; v. 1336-1807 (p. 41 55 ), para o duelo judicial entre Gaydon e Thibaut.
} 
informando da última traição dos Ganelidas, o sequestro de Carlos, e ordenando-lhe ir salvar o rei ${ }^{307}$.

Apesar das muitas fraquezas do rei, Gaydon mantém o respeito pelo monarca. $\mathrm{O}$ desafio ao senhor é postergado ao máximo, na esperança de que este voltasse a agir de acordo com as expectativas de seu ministério. Se o jovem conde angevino é tomado de algum arroubo contra Carlos, seus velhos servidores, como o duque Riol do Mans, o lembram de seus deveres e das exigências do contrato vassálico, a principal delas a manutenção de uma fidelidade heroica ao senhor, mesmo se o comportamento deste fosse censurável. Em sua raiva, por ser acusado injustamente pelo imperador e denunciado falsamente por Thibaut d'Aspremont, Gaydon diz a seus homens desejar ferir o rei, sendo imediatamente criticado por Riol,

Hé! fel gloutons, dist Riolz, que diz, tu?

Ton droit seignor, se l'avoiez feru, Devant celle hore que il deffiez fust, Jamais en cort ne seroiez connus Que chevaliers ne tendist ton escu. (v. 807-811).

O direito de guerrear contra o senhor faltoso não é negado no poema, mas para isso acontecer era primeiro preciso respeitar os rituais de diffidatio, com o desafio a quem não cumprira com suas obrigações. Esperava-se não chegar ao ponto de ruptura do laço vassalico, mas o poema joga com a falta de discernimento do monarca para a crise ocorrer.

Praticamente todos os ataques de Thierry e seus homens foram voltados contra os Ganelidas, seus verdadeiros inimigos. Além disso, os combates ocorriam por iniciativa destes, empenhados em mover emboscadas contra os angevinos, como a dirigida contra o grupo que retornava a Angers no início do poema. Também violaram o duelo judicial interferindo no combate para socorrer Gui de Autefoille, quase dominado por Ferraut. E houve ainda a tentativa de Hertaut em assassinar este mesmo Ferraut, oferecendo uma falsa hospitalidade em seu castelo.

Logo, o adversário dos rebeldes não era o rei e sim a linhagem de Ganelon. O poema transferia a responsabilidade pelo conflito para o clã da maldade e Carlos ficava apenas como um senhor desorientado graças aos procedimentos de calúnia e lisonja utilizados pelos Ganelidas. Com isso a narrativa afastava o monarca das represálias movidas pelos heróis do poema, mantendo-o imune e inatacável, sendo respeitada a sua condição de escolhido por Deus para conduzir os homens na terra. As punições eram

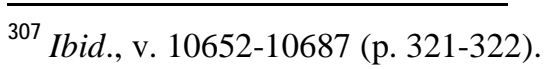


concentradas sobre os Ganelidas, contra quem os "rebeldes" tinham toda a liberdade para agir. Adalbert Dessau, em 1960, alertara sobre esse procedimento na epopeia francesa, na qual a solução jurídica envolvendo a morte de quem fosse traidor era desviada da pessoa do rei e direcionada para outros personagens, salvando o princípio de inviolabilidade do monarca $^{308}$.

Se, como afirma J. Subrenat, o poema Gaydon foi escrito por um poeta / jogral do Anjou quando da sua anexação aos domínios capetíngios, podemos entender algumas de suas particularidades $^{309}$. Na narrativa era pregada a fidelidade ao monarca, independente das ações condenáveis por ele realizadas e, ao mesmo tempo, o Carlos Magno que deveria comandar todo o reino da França e tinha um passado épico enaltecedor, é mostrado neste poema como uma figura patética. $\mathrm{O}$ respeito pela instituição monárquica e pelo seu representante não significava para os angevinos um olhar condescendente e submisso sobre sua imagem. O Anjou dos Plantagenetas manteve uma luta constante contra os Capetíngios desde a metade do século XII e era difícil aceitar o fato de terem sido conquistados, na primeira metade do século XIII. Por outro lado, as histórias das revoltas durante o reinado de Henrique II, nas quais não apenas os grandes feudatários, mas também os próprios filhos dele estavam envolvidos, deve ter pesado muito nas considerações dos poetas ao escreverem ou cantarem suas obras.

Por último temos o Jehan de Lançon, que é muito distinto dos demais poemas envolvendo a luta de um vassalo contra o rei épico carolíngio. Além de tardia, a Canção se mostra hostil ao barão cujas terras são invadidas pelo imperador, estando este determinado a dominar ou prender o seu adversário, muito embora tecnicamente Jehan nem fosse vassalo de Carlos. Era o fato daquele barão independente, senhor de grandes propriedades nas terras cristãs, não ser seu subordinado o que inspirara o imperador a querer guerrea$10^{310}$.

Para poder desenvolver sua narrativa nesse sentido, o poeta se viu obrigado a, primeiramente, desqualificar Jehan e fez isso o identificando como sendo um parente dos Ganelidas. Apesar de hostil à corte de Paris, os seus primos e tios são membros dela, compartilham o mesmo espaço dos outros conselheiros do rei. Mas, secretamente, eles ambicionam domina-la e até depor Carlos Magno.

\footnotetext{
${ }^{308}$ DESSAU, Op. cit., p. 25-26.

${ }^{309}$ SUBRENAT, Op. cit., p. 423-424.

${ }^{310}$ BOUTET, La politique et l'histoire ..., p. 1126-1127.
} 
Jehan é representado como um senhor sem laços com o rei carolíngio, não lhe devendo serviço ou fidelidade. Aparece também como um adversário de Carlos, tendo movido uma guerra feroz contra os franceses e mesmo derrotado estes em batalha, conforme lembra Rolando quando o imperador expõe sua intenção de combater o senhor de Lançon $^{311}$.

O personagem título deste poema é visto como um "rebelde" por não se submeter ao poder de Carlos Magno, considerado o senhor supremo da Cristandade, o guia das hostes cristãs contra os pagãos e o responsável pela justiça nas terras onde vigora o cristianismo. O poema não considera justificável um barão cristão permanecer fora da influência do imperador. Por seu lado, Jehan luta para manter sua independência e ao fazer isso ameaça dividir o mundo cristão, ainda mais tendo como aliados Ganelon e seus parentes. Estes vão acender a cobiça do senhor de Lançon, oferecendo-lhe a oportunidade de ser rei da França.

Essa situação justifica, no final do poema, a derrota de Jehan e o seu aprisionamento. Isso é algo inadmissível nos poemas anteriormente estudados e em outros poemas do Ciclo de Doon de Mayence. Houve um trabalho por parte do autor desta Canção de fazer do vassalo alguém que merecia a derrota. O poema foi feito para exaltar a figura de Carlos Magno na condição de um soberano intransigente e belicoso, mas capaz de submeter quem lhe fosse contrário. Em contrapartida, não se admite nenhuma veleidade de independência a qualquer barão cristão, devendo estar todos submissos ao poder do imperador. Esta Canção foi escrita após a derrota dos Plantagenetas e de outros príncipes e senhores territoriais em Bouvines (1214) e das vitórias de Luís IX sobre Henrique III e seus aliados, até ser celebrado o tratado de Paris de 1258, no qual foi selado o desaparecimento do império Plantageneta. No momento em que os monarcas capetíngios dominaram diretamente um vasto território conquistado e controlaram os poucos grandes senhores ainda existentes, uma narrativa épica sobre um Carlos Magno vitorioso sobre um "rebelde" tornou-se possível de ser cantada.

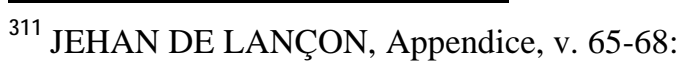

Jehan est orguilleuz et s'est moult ricez hon, Il ne doutte Franchois vaillant ung esporon; Ne se conbaty il mie a nous sous Morimon? La fumez desconfit a grant destruissîon 


\section{2- O "rebelde" entre a desonra e a culpa}

Além de tratar das questões políticas e legais ligadas à vassalidade, às relações entre barões e seu rei e à própria função régia no quadro de uma monarquia feudal, as Canções de Gesta em geral e o Ciclo de Doon de Mayence em particular, podem levantar outro problema referente ao comportamento cultural da aristocracia cavaleiresca. Trata-se da questão da honra ou do sentimento de desonra como fator inicial da revolta, como motivo desencadeador do conflito entre senhor e vassalo.

A poesia épica francesa pode ser vista como uma forma de trabalhar literariamente o choque entre uma cultura da desonra ou vergonha, herança de tradições antigas Grecoromanas e germânicas, e uma cultura da culpa ou pecado, criada com o advento do Cristianismo. No caso de mentalidades baseadas na desonra, se alguém realiza um ato considerado pelo atingido como motivo de vergonha para si ou para sua linhagem é obrigatório dar uma resposta agressiva para punir o ofensor e lavar a honra do ofendido. Este tipo de representação foi elaborado pela antropóloga Ruth Benedict ao estudar o comportamento dos japoneses e tentar entender o motivo das acentuadas diferenças entre as culturas nipônica e ocidental ${ }^{312}$. Mas no caso japonês a reação de quem se julga desonrado pode ser direcionada tanto contra o ofensor quanto à própria pessoa do ofendido, através do haraquiri. Esta opção pelo suicídio, se foi aceita pelos gregos da época clássica (século V a.C.) e pelos romanos até os primeiros séculos da nossa era, acabou rejeitada quando o Cristianismo se firmou no Ocidente e este passou a ensinar que isso era um crime, como afirmou Santo Agostinho em $A$ cidade de Deus ${ }^{313}$. Durante a Idade Média a condenação ao suicídio tornou-se ainda mais forte e se ele era ainda frequente, alegava-se ter ocorrido devido ao caráter pecador de quem o cometeu ou por este estar influenciado pelos demônios ${ }^{314}$.

Para o Ocidente medieval a única forma de responder a uma ação desonrosa era punir o ofensor. Como a sociedade estava baseada em agrupamentos humanos, o primeiro deles a família ou linhagem, enveredava-se para o caminho da vingança e o fato gerador dela, mesmo que fosse decorrente de disputa entre dois indivíduos apenas, degenerava em

\footnotetext{
312 BENEDICT, Ruth. O crisântemo e a espada. Padrões da cultura japonesa. SP: Perspectiva, $2^{\mathrm{a}}$ edição, 1997, p. 188-190.

${ }^{313}$ AGOSTINHO (Santo). A cidade de Deus. Petrópolis: Vozes, vol. 1, $2^{\text {a }}$ edição, 1990, p. 46-55, onde trata principlamente do suicídio da matrona romana Lucrécia.

314 BOURQUELOT, Félix. Recherches sur les opinions et la législation en matière de mort volontaire pendant le Moyen Age. Bibliothèque de l'école des chartes. T-III, 1841-1842, p. 539-560; T-IV, 1842-1843, p. 242-266, 456-475.
} 
uma luta coletiva, na qual cada grupo buscava vingar-se do último ataque sofrido ${ }^{315}$. Mais do que uma cultura de desonra ou honra, D. Barthélemy mostra o mundo feudal europeu do medievo como uma sociedade da vingança e, portanto, contando com procedimentos capazes de impedir um ascender ilimitado dos confrontos entre famílias ${ }^{316}$.

Nas Canções de Gesta os conflitos decorrem da negação de justiça por parte do senhor, no nosso caso Carlos Magno. Mas esse pedido de justiça se originou de um atentado à honra dos barões e cavaleiros. Assim, Girart de Vienne foi humilhado pela rainha em público, quando ela se vangloriou de tê-lo feito beijar seu pé. Como consequência, Aymeri, o sobrinho de Girart, tentou matar a rainha e, depois, foi uma exigência do clã de Monglane a entrega dessa mulher para ser decapitada. Podemos considerar esse episódio como parte do que Bertrand chamou de "començaille" (v. 87), o início da história, desconhecido dos outros poetas e jograis e descoberto por ele. $\mathrm{Na}$ verdade o autor da Champagne precisava encontrar uma justificação para a luta contra o imperador, diferente da lenda tradicional, e ela passava necessariamente por um ato no qual o herói fosse desonrado, envergonhado, e o seu direito de vingança negado por seu senhor Carlos.

No início da Gesta Renaut de Montauban, Bueves de Aygremont se sentiu ofendido por Lotário em sua própria corte e por isso ordenou o ataque aos mensageiros franceses. Isso também era uma forma de justificar seus atos condenáveis. Mas contra o barão pesavam duas censuras graves. Uma delas lembrada por Ogier o Dinamarquês, era de Lotário ser ainda jovem e Bueves um homem e senhor feito. O primeiro, pela própria juventude, teria um comportamento arrebatado e o segundo, pela idade, devia ter-se mostrado sábio e tolerante, como o aristocrata venerável que Bueves era. Matar o filho do imperador só serviu para levar este a desejar vingança e ficar satisfeito apenas depois do assassinato do barão de Aygremont e da derrota militar dos parentes deste.

Quanto a Reinaldo, ele fora humilhado pela agressão de Bertolai, ao ser esbofeteado por este durante uma partida de xadrez. Dirigiu-se a Carlos Magno para pedir uma compensação, algo fácil de ser obtido devido a simplicidade da afronta. Mas o herói não se ateve ao seu caso e pediu indenização do rei pela morte de seu tio Bueves, considerando esta uma desonra para sua família e pondo em causa o acordo de paz feito

\footnotetext{
${ }^{315}$ BLOCH, M. Op. cit., p. 186-192.

${ }^{316}$ BARTHÉLEMY, Dominique. Nouvelle histoire des Capétiens - 987-1214. Paris: Seuil, 2012, p. $20-24$.
} 
com os irmãos do morto, no qual se perdoara o ato do imperador. Como nada obteve, Reinaldo matou Bertolai e acabou banido da corte e da casa paterna.

No caso do poema Gaydon a desonra de Thierry tem várias motivações: a acusação falsa feita pelo rei, decorrente da tentativa de envenenamento; o esquecimento por Carlos dos serviços prestados pelo jovem a ele; a negativa do rei em punir os culpados pelas traições na corte; a aliança de seu senhor com os Ganelidas, inimigos de Gaydon e dos angevinos. A diferença principal deste poema em relação às outras Canções é o de ser uma narrativa desenvolvida de forma a preservar o monarca em erro, permitindo o lançamento de toda a força da vingança sobre a linhagem de Ganelon.

Para essa cultura cavaleiresca a ocorrência de desonra obrigava a busca de vingança. Em compensação, nos mesmos poemas onde vemos o empenho em vingar uma afronta, encontramos o arrependimento como fator de reintegração dos "rebeldes". Isso coloca o princípio da cultura da culpa ou pecado como a chave para o final do poema e o encerramento do conflito entre senhor e vassalo. Mas o fim da luta só ocorre quando o orgulho guerreiro e o desejo de vingança deixam de ser o móvel de sua conduta. Alterando sua postura o envolvido passa a buscar uma penitência para as suas faltas, submetendo-se àquele a quem combatera de forma encarniçada e aceitando alguma punição determinada pelo seu adversário, se este o desejasse.

Assim, Girart de Vienne renuncia à vantagem obtida quando encontrou Carlos Magno sozinho na floresta e, ao invés de capturar o imperador, lança-se aos seus pés pedindo perdão e a oportunidade de voltar a servir fielmente o seu senhor. Isso implicava a renúncia a todo e qualquer pedido de compensação pela afronta feita pela rainha - que já desaparecera da narrativa, desde o início do cerco de Vienne. Em certo sentido isso significava, também, ter Girart assumido para si a culpa pelo início do conflito, pois foi ele quem se colocou na posição do pecador em busca de redenção diante daquele cujo ministério incluía a obrigação de perdoar os arrependidos. Esse poema épico praticamente se encerra com essa relação entre o "rebelde" contrito e o senhor misericordioso.

Para o personagem Reinaldo de Montauban o uso da culpa ou pecado como fator de reinclusão na corte régia é bem mais demorado e difícil do que para Girart. Os Aymonidas encontraram um Carlos Magno muito mais obstinado em seu poema. O próprio imperador, vencido pelo princípio da desonra ou vergonha, não via outra possibilidade para o fim da guerra a não ser a destruição de seus adversários. Enquanto isso Reinaldo sempre ao encontrar o rei pedia a este, de joelhos, o perdão pelas suas faltas e a de seus irmãos. E, no final, mesmo tendo sido a paz obtida através de uma demonstração de força dos 
Aymonidas, ainda assim o monarca apareceu como aquele cujas palavras garantiam o perdão dos pecadores e oficializava qualquer penitência a ser realizada pelos culpados de uma falta. Para Reinaldo fazer a peregrinação ao Santo Sepulcro, precisou-se da autorização de Carlos. Enquanto isso, para Carlos voltar a ser um imperador respeitado, ele teve que assumir o papel de quem perdoa ou dá a penitência ao pecador para este ter condições de ficar livre de suas culpas.

No nosso entendimento, este choque entre cultura da desonra e da cultura do culpa ainda não foi convenientemente estudado nas Canções de Gesta e, talvez, também nas literaturas voltadas ao tema arturiano e ao tema da antiguidade. Neste trabalho levantamos a questão apenas como uma forma de entender a motivação da luta do "vassalo rebelde" contra seu senhor e por qual meio a poesia épica encontrava uma solução para esse conflito. 


\section{5- A LINHAGEM DOS TRAIDORES}

A poesia épica francesa, para explicar derrotas como a de Roncesvales ou as lutas internas que enfraqueceram o império carolíngio, criou uma série de personagens os quais assumiram o papel de traidores para serem responsabilizados por essas crises. O primeiro deles parece ter sido Ganelon. Entretanto algo ocorreu durante a difusão das Canções de Gesta transformando esse barão infiel em uma espécie de patrono ou representante maior de todos os elementos desprovidos de respeito pelas relações de fidelidade. No final do século XII a linhagem, cujo crime havia se limitado a cumprir os deveres do sangue na defesa de um de seus membros acusado de perjúrio ao rei, tornou-se ela própria maculada com a predisposição para trair seu senhor e os demais membros da corte. Este é o tema principal deste capítulo.

\section{1- Transformações do personagem Ganelon e de sua linhagem}

A primeira coisa a ser notada no Ganelon da Chanson de Roland foi o ter sido individual, pessoal, o seu ato de traição. Escolhido contra a sua vontade para ser mensageiro em Saragoça, objeto de um riso jocoso de Rolando ao proferir suas ameaças, o barão lançou o seu desafio contra o sobrinho do imperador e contra os amigos deste. Seu desejo de vingança foi dirigido para membros da hoste franca cuja diferença em relação a ele era apenas estarem mais próximos do rei na corte e nos conselhos. Ganelon planeja e age sozinho. A sua decisão de trair surge durante suas conversas com Blancandrino e concretiza-se no encontro reservado com Marsílio, onde ele jura entregar os doze pares aos sarracenos,

\footnotetext{
La traïsun me jurrez e le plait! [diz o rei pagão]

Ço respunt Guenes : Issi seit cum vos plaist! Sur les reliques de s'espee Murgleis La traïsun jurat, si s'est forsfait.
}

(v. 605-608).

Ele assumira individualmente o acordo com os inimigos de seu senhor e jurara realizar a traição tocando os objetos sagrados guardados no punho de sua espada. O público do poema sabia que o barão tinha consciência de seu ato, de seu crime. 
A linhagem de Ganelon desconhece essa traição. Nenhum de seus membros acompanhou o mensageiro à cidade pagã. Ninguém da parentela viu, ouviu ou expressou seu ponto de vista quando o acordo de traição foi firmado. Não que ela não se importasse com a segurança Ganelon, mas porque este vetara a ida de qualquer outro barão junto com ele $^{317}$.

Quando da corte de justiça para julgar o traidor, a linhagem apenas seguiu o princípio aristocrático e linhageiro de defender um de seus membros acusado de um crime. Ver alguém da parentela ser punido, possivelmente com um tipo de morte degradante, seria uma humilhação para todos e, portanto, uma desonra a ser evitada a todo custo. Por conta dessa forma de encarar a questão, desconsiderando tratar-se do próprio rei a parte atingida pelo ato de Ganelon, a família como um todo pagou com a vida por colocar-se contra o direito de seu senhor na vã tentativa de proteger o culpado ${ }^{318}$.

Não foram poucos os estudiosos que tentaram de certo modo "compreender" o personagem Ganelon e os seus atos na Chanson de Roland. Chegou-se a responsabilizar Carlos Magno de estar querendo a ruína desse barão ou o descaso de Rolando por seu padrasto. Para alguns pesquisadores Ganelon era um personagem trágico, levado à própria destruição por defender concepções morais ultrapassadas, nas quais se valorizava a honra pessoal, sem atentar para as mudanças ao seu redor, sendo a principal delas a necessidade de obedecer e respeitar um poder monárquico fortalecido, conforme se readquiria consciência da noção de Estado, a partir do século XII ${ }^{319}$. Há inclusive uma aproximação do comportamento de Ganelon com o de Rolando, ambos preocupados apenas com a sua honra, um tentando vingar-se de um ultraje sofrido, o outro tentando evitar a desonra pessoal e familiar caso não se comportasse de forma corajosa - e temerária - durante um combate desesperador $^{320}$. Aos dois se oporia Olivier, preocupado com os interesses de seu senhor Carlos Magno e do bem público, mas incapaz de impor sua visão de mundo e obrigado pela fidelidade aos companheiros a segui-los para o desastre.

\footnotetext{
${ }^{317}$ CHANSON DE ROLAND, v. 349-365.

${ }^{318}$ BLOCH, M. Op. cit, p. 183-186.

${ }^{319}$ HAIDU, P. The Subject of Violence. STRANGES, John A. The Character and the Trial of Ganelon. A New Appraisal. Romania, T-96, 1975, p. 333-367. MICKEL, E. J. Ganelon, Treason, and the "Chanson de Roland.

${ }^{320}$ GERARD, Alb. L'axe Roland-Ganelon: valeurs em conflit dans la Chanson de Roland. Le Moyen Age, TLXXV, 1969, n 3-4, p. 445-465. HALVERSON, John. Ganelon's Trial. Speculum, Vol. 42, 1967, n 4, p. 661-669. JONES, George Fenwick. The Ethos of the Song of Roland. Baltimore: Johns Hopkins Press, 1963.
} 
O esquema no qual o traidor age sozinho e a parentela é punida por defendê-lo, mas sem ter participado da traição, sofre mudanças conforme a lenda rolandiana é transmitida durante o século XII. No início do século XIII as caracterizações de Ganelon e de sua parentela terão se alterado a ponto de se oporem às imagens existentes na Chanson de Roland do manuscrito de Oxford.

Essas alterações atingem inicialmente ao próprio Ganelon nas demais versões poéticas sobre o desastre de Roncesvales. Nos manuscritos Venise 4 (posterior, mas próximo ao de Oxford), Châteauroux / Venise 7, Paris, Cambridge e Lyon ${ }^{321}$ ocorre a inclusão de dois episódios narrando fugas do traidor. A primeira delas se dá quando a hoste franca ainda está voltando da Espanha. Ganelon consegue se armar e abandona o acampamento, tentando chegar a Saragoça, onde pensa encontrar refúgio junto a Marsílio. Um cavaleiro, Oto, persegue-o e após um combate difícil consegue recaptura-lo e trazê-lo de volta ao exército cristão ${ }^{322}$. A segunda escapada ocorre já em Laon, com o barão fugindo para evitar o combate judicial requerido pelo julgamento de sua traição e no qual ele lutaria. Mesmo a sua linhagem não sabe de suas intenções e o arma pensando estar ele indo para o duelo. Mas tão logo é percebida sua fuga um dos cavaleiros fieis ao rei, Gundebeuves o Frisão, vai ao seu encalço e Ganelon é novamente preso $^{323}$. Os dois episódios vêm reforçar a ideia de que o criminoso tinha consciência de sua traição e, pior, caso o julgamento ocorresse ele não teria como evitar a pena capital ou a morte no duelo. Fugir funcionava como uma confissão de culpa e, no caso da poesia épica, aumentava as reservas do público em relação ao personagem identificado como traidor.

Em pelo menos uma dessas versões do Roland, a contida nos manuscritos Châteauroux e Venise 7, ocorre um rebaixamento moral do personagem quando da sua indicação como embaixador aos pagãos. Após reclamar de seu envio para Saragoça, o imperador o censura: "Culvert, dist il, li cors Diu mal te die! / Ge t'ai prové de mainte felonie!" (Venise 7, v. 369-370). Depois disso Ganelon ainda ameaça Rolando e Olivier tenta agredi-lo, mas é impedido pelos demais barões (Venise 7, v. 375-385) ${ }^{324}$. Essas

\footnotetext{
${ }^{321}$ CHANSON DE ROLAND (La) / The Song of Roland, The French Corpus. General editor Joseph J. DUGGAN. T-I : The Oxford Version, edited by Ian SHORT; The Venice 4 Version, edited by Robert F. COOK. T-II: The Châteauroux - Venice 7 Version, edited by Joseph J. DUGGAN. T-III: The Paris Version, edited by Annalee C. REJHON; The Cambridge Version, edited by Wolfgang G. VAN EMDEN; The Lyon Version, edited by William W. KIBLER. Turnhout (Belgium): Brepols, 2005.

$322 \mathrm{O}$ episódio corresponde às laisses 323-333 de Venise 4; 333-343 de Venice 7; 341-351 de Châteauroux; 265-283; 236-253 de Cambridge; 126-136 de Lyon.

${ }^{323}$ Isto corresponde às laisses 376-380 de Venise 4; 405-409 de Châteauroux; 399-404 de Venise 7; 334-339 de Paris; 305-310 de Cambridge; 179-184 de Lyon.

${ }^{324}$ No manuscrito Châteauroux corresponde aos versos 359-360 e 365- 375, respectivamente.
} 
adições marcam uma transformação do caráter do personagem de modo a torna-lo cada vez mais condenável. Apesar dessas alterações na sua caracterização, nos diversos poemas sobre Roncesvales, Ganelon permanece sempre um traidor solitário.

A Canção de Girart de Vienne, na versão de Bertrand de Bar-sur-Aube, apresenta a primeira menção de uma linhagem de Ganelon. Na verdade o patrono da parentela é Doon de Mayence, mas nela se concentram barões e cavaleiros conduzidos pelo orgulho, arrogância e cobiça a realizar atos condenáveis. O único nome mencionado como membro da linhagem foi o do traidor de Rolando ${ }^{325}$ e, portanto, o poeta deixava entrever que não se podia esperar um bom comportamento do resto da família, pois pelas suas virtudes guerreiras seriam notáveis no reino, "s'an eus n'eüst orgueil et traïson” (v. 32). A divisão em três "Gestas" compôs um grupo de poemas dedicados ao rei, tendo Carlos Magno como personagem principal; um de possíveis traidores, o de Doon de Mayence; e um grupo cuja linhagem numerosa, a de Garin de Monglane, era composta de bons vassalos, dispostos a sacrificar-se pelo seu senhor e a combater quem o ameaçasse. Três vértices de um triângulo onde o rei esta na ponta superior e abaixo dele, sendo observados por ele, a linhagem dos bons vassalos e a dos maus vassalos, no mesmo nível, uma em cada ponta, e em constante disputa. Essa é a imagem que, no final, marcará a corte do Carlos Magno épico.

As transformações relativas ao traidor juntamente com sua linhagem começam a tomar forma no final do século XII, mas mantém características por vezes contraditórias, tanto em relação à Chanson de Roland como em relação aos poemas posteriores. Assim, no Fierabras existem dois episódios marcantes envolvendo Ganelon, um dos quais o faz diferente do resto de sua família. Durante um combate por Maltrible, Carlos imprudentemente avança mais do que suas tropas e penetra na cidade. Logo atrás dele estão os cavaleiros da linhagem ganelida. Alguns membros desta sugerem o abandono do imperador e o retorno à França, da qual tomarão posse para $\mathrm{si}^{326}$. Ganelon se opõe a esse plano e diz preferir permanecer junto ao imperador mesmo se fosse para morrer,

Ne plache Dex, dist Guenes, qui en croiz fu penez,

Ke ja en tel maniere soit mi sire tuez.

Mex woil avoir la teste et les membres coupez

Ke mon poier n'en fache, ja n'en serai blasmez.

(v. 5158-5161),

\footnotetext{
${ }^{325}$ De ce lingnaje, ou tanto t de boidie / fu Ganelon ... (v. 21-22)

${ }^{326}$ FIERABRAS, v. 5118-5166.
} 
e isso chocou os seus parentes, mais propensos a trair do que o personagem então visto como o maior representante da traição. Algumas laisses adiante, Carlos o escolhe para ser mensageiro junto ao rei pagão, o almirante Balant, e Ganelon não só aceita a missão sem pestanejar, como ainda comporta-se como um modelo cavaleiresco cristão, pois ameaçado na corte sarracena mata um dos chefes inimigos e é obrigado a fugir com todo o exército adversário a persegui-lo ${ }^{327}$. O poeta deixará claro depois que apesar desses atos elogiosos Ganelon iria trair porque essa tendência estava no seu sangue, fora herdada de sua linhagem. Isso representou uma enorme alteração se compararmos este poema ao Roland. O padrasto de Rolando podia ser mostrado em alguns momentos com nobreza de caráter, enquanto a sua linhagem não apresentava essa característica e, pelo contrário, desprezavaa. Temos aqui talvez um testemunho do começo da inversão do papel de Ganelon, de único responsável pelo desastre de Roncesvales para a condição de produto de uma linhagem marcada por comportamentos condenáveis, insidiosa e incapaz de manter sua fidelidade ao senhor ou à causa cristã.

Há outro poema, Gui de Bourgogne, que na verdade é uma variante do Fierabras, sobre as lutas de Carlos Magno na Espanha. O clã ganelida não é muito citado, mas quando aparece está tentando induzir o imperador a fazer algo injusto ou se retirando com medo de enfrentar um possível combate com os sarracenos, quando na verdade estão vendo a chegada dos reforços reunidos por $\mathrm{Gui}^{328}$. Infelizmente não encontramos indicações sobre relação entre os dois poemas e embora o personagem Gui da Borgonha apareça em ambos, ele toma papéis diferentes em cada um deles. No Fierabras era um dos doze pares e está participando desde o início da expedição, e no poema seu homônimo ele nascera após a partida de seu pai para a Espanha, crescido em Paris tornara-se o líder dos filhos dos grandes barões franceses, ausentes já havia mais de vinte anos devido à luta além Pirineus, e a quem os jovens vão socorrer. De qualquer modo, isto mostra como ainda era variável a apresentação de Ganelon e de sua linhagem, entre 1180 e 1200.

Quando foi composto o poema Renaut de Montauban do manuscrito Douce, no início do século XIII, os Ganelidas já estavam organizados de modo a representar a fonte da discórdia dentro do reino franco. Eles eram apresentados como um grupo muito numeroso, coeso, com muitos recursos materiais e com bons combatentes. Constituiam um poder respeitável dentro da Cristandade e se opunham às demais linhagens da corte régia.

${ }^{327}$ Ibid., v. 5631-5727.

${ }^{328}$ GUI DE BOURGOGNE, v. 3842-3871. 
O clã de Ganelon é favorecido em tempo de guerra. Por esse motivo interfere nas ocasiões onde existe a possibilidade de um acordo de paz para impedir a sua concretização. Ele fornece ao imperador os guerreiros necessários para a realização de atos condenáveis, no caso as emboscadas contra Bueves de Aygremont ${ }^{329}$ e contra os Aymonidas, em Vaucoulours ${ }^{330}$. Carlos não encontraria apoio nas outras linhagens para realizá-las, daí sua dependência dos Ganelidas nessas ocasiões.

Essa conduta de lealdade interesseira da parentela ganelida acabava por incentivar o rei a continuar agindo de modo errado, na visão do poeta. Contando com o apoio de um grupo numeroso e poderoso, Carlos acreditava ter condições de lutar até a vitória contra os filhos de Aymon e contra o mágico/ladrão Maugis. Com isso afastava-se dos antigos conselheiros, como Naimes e Ogier, cujas palavras não lhe eram agradáveis.

A linhagem de Ganelon depende tanto da guerra, que perde espaço quando a paz é finalmente alcançada. A partir do momento do perdão de Carlos aos Aymonidas altera-se a relação de influências dentro da corte real. Os Ganelidas praticamente desaparecem, enquanto os membros de clãs adversários assumem a condição de principais conselheiros. Talvez o termo "clãs adversários" não seja o mais conveniente. Durante todo o desenrolar da história do Renaut de Montauban, o poeta se esforça em unir todos os heróis e os bons vassalos em uma única linhagem. Não é apenas Ogier o Dinamarques que é primo dos "rebeldes"; Turpin, Olivier, quase todos os pares da França 331 . Rolando é chamado por Reinaldo de primo ${ }^{332}$. E o poeta deixa escapar a possibilidade de ser o herói um sobrinho do imperador ${ }^{333}$. De certo modo, voltamos a encontrar a figura do triângulo já presente no poema Girart de Vienne. Mas no caso da Canção Renaut de Montauban há uma maior clareza no papel de cada ponta. Carlos Magno pairando no vértice superior, como um ente à parte nas relações de sangue, e inclinando-se para cada um dos outros, conforme a situação enfrentada ou de acordo com os caprichos pessoais do imperador. Na base do triângulo, em lados opostos, as linhagens boa e má digladiam-se para ver quem iria ter proeminência junto ao monarca. A preferência régia por um dos lados descarta automaticamente o outro. Daí a luta constante entre as duas parentelas e o esforço

\footnotetext{
${ }^{329}$ RENAUT DE MONTAUBAN, v. 1368-1390.

330 Ibid., v. 6279-6295. Fouque de Morillon é citado muitas vezes nas laisses posteriores, com Renaut acreditando encontra-lo como enviado para um acordo de paz.

${ }^{331}$ Ibid., v. 9249-9493, nos quais Carlos Magno chama vários barões para enforcar Ricardinho, o mais moço dos Aymonidas, e cada um dos convocados nega-se a cumprir tal ordem, muitos alegando seu parentesco com o prisioneiro.

332 Ibid. v. 8528-8529.

333 Ibid., v. 935; 9423-9424.
} 
Ganelida em manter os Aymonidas como inimigos de Carlos, pois desse modo eles afastavam os conselheiros adversários, ligados pelo sangue aos "rebeldes".

Já na Gesta Gaydon a imagem da linhagem de Ganelon é tornada mais nítida e precisa: ela conspira contra o rei, deseja mata-lo, dominar a França, destruir todos os seus opositores e usufruir das riquezas do reino em seu exclusivo benefício, como dissera no início Thibaut d'Aspremont ${ }^{334}$. Este poema retoma certas características presentes no Fierabras, fazendo dos Ganelidas uma ameaça potencial ao império cristão, pelo anseio de tomá-lo egoisticamente para si. Mas o poeta do Gaydon leva mais longe o objetivo de rebaixar moralmente essa linhagem.

Primeiramente essa parentela viciosa constitui a fonte de toda a discórdia entre o bom vassalo e seu rei. Através de insinuações, mentiras, falsas acusações e dissimulações os Ganelidas conseguem fazer com que Carlos veja em Gaydon um inimigo mortal. Com isso quebra-se o laço entre o fiel servidor e seu senhor. No vácuo surgido na corte com a partida do injustiçado, a má linhagem encontra espaço para instalar-se e começar a influenciar o comportamento do imperador, de acordo com seus interesses egoístas. E não adiantou o juízo de Deus na vitória de Thierry no duelo contra Thibaut d'Aspremont, pois apesar de provada a inocência do vencedor na tentativa de envenenamento do rei, este usará essa acusação para justificar seus atos hostis ao angevino até quase o fim do poema. Isso graças ao ascendente tomado pelos Ganelidas junto a Carlos.

Outra consequência da liberdade de ação da má linhagem é a difusão de injustiças no reino, pois como dispunham de poder como consequência de sua proximidade com o monarca, ela podia fazer exigências absurdas aos demais barões do reino e impor sanções contra quem não lhes fosse simpático. Foi o caso do senhor encontrado por Ferraut no retorno de sua embaixada a Paris, condenado a não caçar de modo nobre por instigação dos Ganelidas. Segundo sua filha, o nobre homem,

N'ose avoir chiens corrans ne chacerie, Et si nen a fors d'autre chose envie ; Mais l'empereres li deffent e devie, Por.I. lyngnaige cui Jhesus maleie, Par lui est meute mainte diablerie: C'est Auloris, cui li cors Deu maudie, Guimars li fel, cellu pute lyngnie, Qui touz jours chasent traïson et boisdie, Qui mon seignor ont tolu chacerie, Et tolu terre par lor losengerie. (v. 3953-3962) ${ }^{335}$.

${ }_{334}^{334}$ GAYDON, v. 96-108, p. 4.

335 Ibid., p. 120. 
O episódio era uma forma simples de mostrar como poderia ser nociva uma parentela alheia aos ideais morais cavaleirescos, movida apenas pelo desejo de ganho e poder. As outras linhagens seriam perseguidas e teriam confiscados os privilégios que caracterizavam sua nobreza, como o direito à caça com o uso de cães.

O poeta também se esforça para mostrar a clã de Ganelon como degenerado e uma das formas de marcar essa condição é o uso recorrente por ela do envenenamento. $\mathrm{O}$ Gaydon é um poema onde o uso do veneno é citado várias vezes. Trata-se de uma forma condenável de matar uma pessoa, visto como assassinato (murdre $)^{336}$. A vítima não sabe do perigo que corre e confia nas pessoas do seu entorno. Quanto ao assassino, além de matar sem dar oportunidade de defesa, aproveitando-se da proximidade do seu alvo, faz isso de maneira a não ser identificado e procura evitar, desse modo, a punição por seu crime.

Outra característica é a desses personagens não respeitarem os próprios membros da sua linhagem. Há dois exemplos onde são descritos barões cujas maldades incluíam o assassinato do pai e da mãe, indicando que para eles os laços familiares e o amor filial nada significavam. Sobre Guinemant o poeta diz,

Quant il fu jones, moult iot put anfant, Car il aprinst empoisonnement tant, Dont il fist puis maint mal en son vivant : Son pere ocist par puison en buvant, .II. de ses freres estraingla en dormant, De sa puison va sa mere abevrant $C$ 'andui li oil li saillirent errant, Et chaï morte dedens.I. feu ardant. Quant ot ce fait, si s'en torna riant, A son lyngnaige en vint en France errant. (v. 5262-5271) 337

E sobre Humbaut, "Qui as mere ot par poisons enherbée, I Sa fame avoit murtrie et estrainglée" (v. 6921-6922) 338 . Se há união entre esses barões ela decorre de cada um deles ter o mesmo comportamento intrigante, violento, traiçoeiro dos seus companheiros. Tios, sobrinhos e primos tem mais afinidade entre si do que com os pais e os irmãos. Eles estavam juntos para obter vantagens materiais e políticas em detrimento de seu senhor e dos demais aristocratas da corte ou da hoste régia. Essa caracterização do grupo ganelida

\footnotetext{
${ }^{336}$ COLLARD, Franck. Le crime de poison au Moyen Age. Paris: PUF, 2003.

${ }^{337}$ GAYDON, p. 159.

${ }^{338}$ Ibid., p. 209.
} 
todo ele voltado para a realização de atos censuráveis chega a colocá-los à parte na sociedade cristã.

Mais do que denegrir a linhagem de Ganelon, esse poema transforma-os em seres verdadeiramente demoníacos. Se os seus bispos os reúnem para um sermão, é para pregar a realização de todas as torpezas possíveis, para louvar a traição e escarnecer de todos os homens preocupados em seguir os ditames cristãos. Quando Gui de Autefoille vai se bater em duelo judicial com Ferraut, o abade Guirrez, lhe faz um sermão extraordinário, que merece ser citado na integra:

Dist à Guiot: Biau niés, or entendez: Se voz volez faire mes volentez. Et mon commant, la bataille vaintrez. Et tout avant à Dammeldeu voez Que ja à home ne tenras loiautez; Vo seignor lige ja foi ne porterez,

Les loiaus homes traïssiez et vendez, Le mal hauciez et le bien abatez. Se voz à home compaingnie prennez, En devant lui tout adez le loez, Et en derrier à la gent le blasmez. Les povres gens laidengiez et gabez, Les orphelins à tort desheritez, Les vesves dammes lor doayres tolez, Les murtrissors, les larrons souztenez. Et sainte eglise adez deshonorez, Prestres et clers fuiez et eschievez, Rendus et moinnes, par tout les desrobez, Les cordeliers et jacobins batez. Petirs anfans en la boe gietez, Et coiement les prennez et mordez; S'on ne voz voit, as mains les estrainglez. Les vielles gens empoingniez et boutez, Ou an visaiges au mains les escopez. Les abéies escilliez et gastez, Et les nonnains toutes abandonnez. En touz les lieus là où voz esterez. Hardiement mentez et parjurez, Que ja vo foi nul jor ne mentirez. Devant ice que voz la main perdrez. Se voz ce faitez que voz oï avez, Ja à nul jor desconfiz ne serez.

(v. 6438-6469) $)^{339}$

O poema desenvolve um verdadeiro ritual invertido de investidura cavaleiresca difundida nos séculos XII e XIII, quando a Igreja procurou fazer da cavalaria uma ordem submetida aos ditames cristãos, em continuidade aos movimentos da Paz de Deus do século XI. Nesse episódio do poema Gaydon todas as obrigações morais e deveres para com os outros membros da sociedade fossem estes cavaleiros, clérigos, monges, pessoas humildes,

${ }^{339}$ Ibid., p. 194-195. 
crianças, viúvas, velhos, eram conscientemente renegadas, de modo a tornar os membros da linhagem de Ganelon uma "cavalaria do diabo", voltada à realização do mal na Terra. Ao pregarem esse comportamento e tentarem colocar seus desejos em prática, os Ganelidas tornam-se uma ameaça para a existência da Cristandade. Eles subvertem todo o ideário cristão e toda a moral cavaleiresca, como se essa linhagem defendesse a manifestação de um mundo oposto a tudo o que era pregado pela Igreja romana ${ }^{340}$. Se para os demais barões e cavaleiros havia o anseio, herdado da tradição agostiniana, da instalação do reino celeste na terra, para a má linhagem o ideal era a instalação de um reino infernal onde eles pudessem atormentar ou torturar quem não tivesse o seu sangue.

E enquanto Carlos Magno, Gaydon e os demais guerreiros da hoste franca podiam contar com a proteção divina e dos anjos, os Ganelidas tinham a proteção dos demônios e estes eram capazes de evitar a morte de seus protegidos ${ }^{341}$. Há um lado cômico nessa forma de apresentar os membros da má família, nesta Canção, quando é relatada a morte de Guinemant, o parricida envenenador, em combate. A alma deste é arrebatada por dois diabos que saem correndo e jogando-a um para o outro como se fosse uma bola ou peteca:

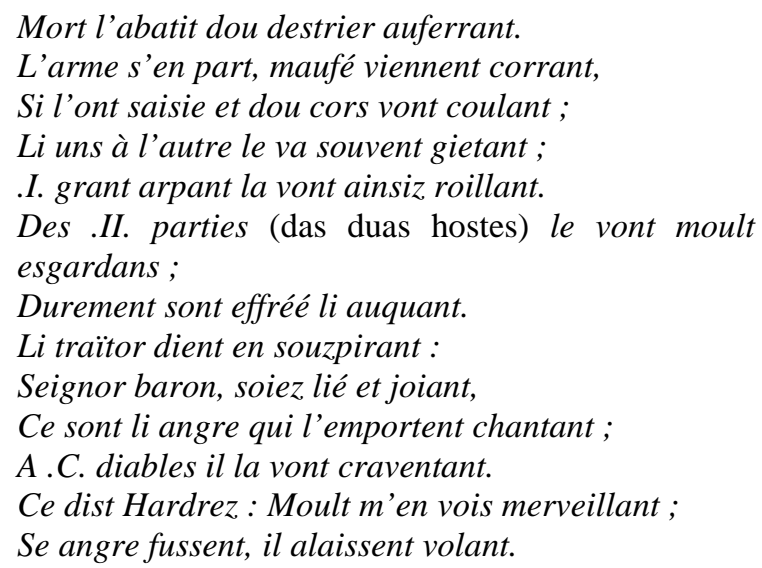

(v. 5282-5294)

Uma descrição destas não é gratuita. O poeta desejava colocar os Ganelidas não apenas como homens desprezíveis, mas também como seres demoníacos, ameaçando a Cristandade e antecipadamente condenados pelos seus pecados. Não há como deixar de comparar, após ver os cultos e as formas de devoção da parentela de Ganelon, com uma espécie de heresia, pois o século XIII deu sequencia a várias delas e ainda viu ser promovida uma cruzada específica contra hereges no sul da França, a Cruzada Albigense

\footnotetext{
${ }^{340}$ FLORI, Jean. L'Essor de la chevalerie: XIe.-XIIe. siècles. Genève: Droz, 1986.

${ }^{341}$ Ibid., p. 204-206: v. 6768-6775, referindo-se a Gui de Autefoille, golpeado por Ferraut; v. 6838-6847, de Guimars, golpeado por Bertrand.
} 
$(1209-1229)^{342}$. O poeta, se originário realmente do Anjou, pode muito bem ter sido influenciado por acontecimentos inquietantes como esse para trabalhar a imagem dos Ganelidas de uma forma tão contrária a todo o pensamento cristão e cavaleiresco então corrente.

O poema Jehan de Lançon também mostra essa linhagem como infiel ao rei, invejosa dos demais barões franceses e capaz de conspirar para conseguir derrubar seu senhor. O ponto mais interessante dessa narrativa é o de ter sido escrita aproveitando-se do material existente em várias Canções anteriores e estar construída de forma a excluir qualquer justificativa do "rebelde" para mover guerra contra o rei.

Para começar não existe qualquer laço vassálico entre Jehan e Carlos. O primeiro é senhor de grandes territórios e não conhece nenhum poder superior ao seu na terra. Mas seus domínios fazem parte da Cristandade e há um rei/imperador épico cujo governo deveria se estender a todas as regiões onde a religião cristã estivesse instalada. Mesmo Constantinopla, capital de outro império no Oriente, submeteu-se a Carlos Magno, conforme consta em um verso da Chanson de Roland, quando o herói expirando lembra suas conquistas $^{343}$, e é narrado no Voyage de Charlemagne à Jérusalem et à Constantinople $^{344}$. Não havia como justificar a independência de Jehan. Ela era, portanto, inaceitável, na visão do poeta. O barão deveria ter feito homenagem ao rei dos francos, mas ao invés disso movera-lhe uma guerra ${ }^{345}$.

Constituindo um poder externo ao império de Carlos, concorrendo militarmente com este e existindo na corte francesa um grupo consanguíneo ao senhor de Lançon, havia a possibilidade de uma conspiração desenvolver-se. Ao mandar os doze pares para as terras de seu inimigo para exigir sua submissão, Carlos desencadeia sem o desejar uma reação dos Ganelidas em defesa do seu parente e contrário às suas intenções expansionistas.

A linhagem de Ganelon vê a fidelidade ao sangue, aos parentes, como superior à fidelidade de ordem vassálica, dirigida a um senhor a quem se jurara servir. Os interesses do clã estão acima dos do reino e da própria cristandade. Quando Carlos ameaça cercar a cidade de Lançon, Ganelon sussurra:

\footnotetext{
${ }^{342}$ BOURIN-DERRUAU, Op. cit., p. 164-169; LUCHAIRE, A . Philippe Auguste ..., p. 276-295.

${ }^{343}$ CHANSON DE ROLAND, v. 2329.

${ }^{344}$ VOYAGE DE CHARLEMAGNE À JÉRUSALEM ET À CONSTANTINOPLE (Le). Texte publié par Paul AEBISCHER. Genève: Droz, 1965, v. 794-803.

${ }^{345}$ BOUTET, D. La politique et l'histoire ..., p. 1125-1127.
} 
Ains en arois soufert mainte dure hachie, Que Jehanz est mes niés de ma serour florie. Manderai mon linnage et ma riche mainnie, Mil en anvoierain a Lanson en aïe.

(v. 1430-1433)

Tendo um aliado poderoso fora das terras imperiais e desejando apoderar-se da coroa, essa parentela tenta de todas as formas suplantar a Carlos para depois entrega-la a algum de seus membros, o próprio Ganelon ou Jehan de Lançon. Como no Gaydon, o resultado do sucesso da má linhagem seria a instalação do reino da injustiça na terra, conforme é declarado pelo padrasto de Rolando:

Encor serei ge rois, qui qu'en poit ne qui non, Et tenrai riche cort a Rains ou a Loon Ne ja n'avrai o moi se tous traïtes non. Je ne seroie un an sans faire trä̈zon, Qui me donroit tout l'or d'une grant region; Itiex sui, itiex erent trestuit mi conpaignon.

Persiste, portanto, o processo de degradação da imagem do clã ganelida no qual este se transforma na fonte de todos os males do reino e quem fosse seu membro não poderia escapar à sina de tornar-se um traidor. Todos os seus integrantes comungam o mesmo projeto de apoio a Jehan e de prejudicar o imperador. Assim, uma de suas primeiras preocupações foi evitar a partida da hoste real em socorro dos doze pares da França. O meio encontrado para paralisar as tropas foi disfarçar alguns homens de sua linhagem em peregrinos e fazê-los mentir quanto a situação na qual se encontravam os cavaleiros de Carlos Magno, dizendo estarem estes em Roma, quando na verdade estavam cercados em Lançon. A condição de peregrinos obrigava os franceses a serem respeitosos com eles e disso se aproveitaram os traidores ${ }^{346}$. Somente quando outro peregrino verdadeiro, mandado por Basin, chega com notícias da real situação de Rolando e seus companheiros, o imperador age para descobrir quem são os falsos peregrinos e para puni-los com a morte por enforcamento ${ }^{347}$. Convém observar que Basin se fizera passar por peregrino para enganar Jehan e poder sair de Lançon em busca de ajuda aos outros franceses, mas não há censura quanto a isto, pois o poeta, ao determinar qual o lado certo e qual o errado, permitia-se a elogiar a malícia de seu herói enquanto condenava a dos seus adversários.

\footnotetext{
346 JEHAN DE LANÇON, v. 1788-1876.

${ }^{347}$ Ibid., v. 2433-2634.
} 


\section{2- Doon de Mayence convertido em traidor}

Como vimos anteriormente, ocorreu desde fins do século XII uma associação dos personagens tidos como traidores com Doon de Mayence, tornado-se este o patrono da linhagem condenada ${ }^{348}$. Mas até fins do século XIII isso não estava totalmente estabelecido. Tanto é assim que Doon de Mayence não é citado nos poemas Renaut de Montauban, Gaydon e Jehan de Lançon. Há muitos outros poemas nos quais há luta entre vassalos e o rei, como Aye d'Avignon e Gui de Nanteuil, onde sequer é mencionado o nome de Doon $^{349}$.

Quanto a um poema sobre esse personagem, ele só apareceria no início do século XIII e procuraria afasta-lo da imagem negativa já existente em um poema de aventuras que segue o estilo das Canções de Gesta, o Beuves de Hamptone ${ }^{350}$. Para isso o poeta insiste na diferença entre os locais onde teriam vivido os personagens, o mau na Grã Bretanha e o bom às margens do Reno ${ }^{351}$. Dos doze filhos de Doon de Mayence, descritos no poema Gaufrey, só um é efetivamente um traidor, Grifon de Autefoille, em um paralelo com os apóstolos nos Evangelhos. E deste mau filho seria gerado Ganelon, o maior dos traidores épicos $^{352}$.

Tendo em vista o esforço para fazer de Doon de Mayence a origem de várias linhagens épicas, fixou-se a ideia de ver incluídos em um Ciclo com seu nome todos os barões épicos empenhados em lutas contra Carlos Magno e mesmo contra Luís o Piedoso. Assim os poemas envolvendo os Aymonidas, Ogier o Dinamarquês, Gaydon, Gui e Garnier de Nanteuil e Girart du Roussillon são colocados como pertencentes a esse Ciclo. Eles não fora realmentem traidores ao rei, pelo contrário, mostravam-se fieis e respeitosos ao senhor, apesar deste persegui-los e, no final das suas Canções, obtinham o perdão régio e voltavam a pertencer à corte de Carlos. Assim vemos certo exagero na afirmação de Dessau de que em determinado momento a resistência ao monarca, até então justificada por alguma injustiça régia, tenha se tornado inadmissível e os cavaleiros envolvidos nessa

\footnotetext{
${ }^{348}$ GIRART DE VIENNE, v. 14-45.

349 AYE D'AVIGNON, chanson de geste anonyme. Édition critique par S. J. BORG. Genève: Droz, 1967. GUI DE NANTEUIL, chanson de geste. Édition critique par James R. McCORMACK. Genève: Droz, 1970.

350 Beuve de Hamptone foi escrito na Inglaterra e a localidade a que se refere é identificada com Southampton. Na narrativa o velho senhor Gui de Hamptone desposa uma mulher mais jovem e esta o trai com o imperador Doon de Mayence, mandando matar o marido e o seu filho Beuves. Este último é vendido a mercadores sarracenos e vai para o Egito, onde se envolve em várias aventuras até conseguir casar com a princesa Josiane e retornar à Inglaterra para vingar seu pai.

${ }^{351}$ DOON DE MAYENCE, v. 3183-3191; 6650-6659.

${ }^{352}$ GAUFREY, v. 79-121.
} 
situação fossem englobados em um "Ciclo dos Traidores", como teria ocorrido com a narrativa sobre Ogier o Dinamarquês ${ }^{353}$.

Embora o Ciclo de Doon de Mayence assim como o conhecemos aglutine os poemas dos vassalos ditos "rebeldes", estes não são responsáveis por qualquer traição. Os poetas os mostram como inimigos dos verdadeiros traidores, membros da linhagem de Ganelon. Mas o personagem Doon de Mayence sofre um processo de difamação à mão dos poetas responsáveis pelos textos franco-italianos e para os poetas franceses após 1300, passando a ser mostrado um traidor e fonte de distúrbios do reino e o seu clã, o dos Mayençais, substituiria o dos Ganelidas como linhagem de traidores ${ }^{354}$.

\section{3- As dificuldades para descobrir, julgar e punir uma traição}

Um dos cuidados tomados por poetas e jograis quando compunham ou cantavam suas Canções de Gesta era o de criar uma situação na qual o crime permaneceria oculto dos personagens não envolvidos em sua execução, mas não dos ouvintes do poema. Assim, a hoste de Carlos Magno desconhecia a perfídia de Ganelon até ser travado o duelo judicial. O mesmo ocorre no início do poema Gaydon, quando os Ganelidas tentaram envenenar o imperador e depois jogaram a culpa no herói. O problema sempre colocado nos poemas era a dificuldade em se provar a traição. Não havia testemunhas diretas e nem provas materiais. Existia apenas uma acusação oral, rebatida com ardor pelo acusado.

O público das Canções sabia da ocorrência da traição, pois o poeta já lhe havia contado em detalhes como ela fora urdida. Os atos dos traidores são descritos de forma explícita nos textos, não deixando qualquer dúvida quanto ao caráter de quem os realizara e o quão nefastas eram suas ações. A entrevista entre Ganelon e Marsílio visava claramente a destruição de Rolando e o fracasso da conquista da Espanha levada a cabo por Carlos Magno ${ }^{355}$. Quando Thibaut d'Aspremont planejou envenenar o imperador, os ouvintes do poema foram informados de seus estudos sobre ervas em Saint Denis, antes de tornar-se cavaleiro e como o traidor pretendia usar isso contra seu senhor ${ }^{356}$.

\footnotetext{
${ }^{353}$ DESSAU. Op. cit., p. 25.

${ }^{354}$ KRAUSS, Henning. Aspects de l'histoire poétique de Charlemagne en Italie. In : CHARLEMAGNE ET L'ÉPOPÉE ROMANE. Actes du VIIe Congrès International de la Société Rencesvals. Liège, 28 août - 4 septembre 1976, Tome I. Paris : Les Belles Lettres, 1978, p. 103-123.

${ }^{355}$ CHANSON DE ROLAND, v. 520-660.

${ }^{356}$ GAYDON, v. 69-159.
} 
Nos poemas épicos, a traição aparece como um crime oculto, desconhecido do rei e de todos os seus conselheiros mais próximos. Para ser descoberta, primeiramente ela deve ser evocada e isso ocorre quando um barão ou o rei diante de uma assembleia ou corte, na condição de acusadores, fazem um discurso ritualizado no qual dizem ter havido uma traição e quem eram os traidores, como Rohart, filho de Fouque de Morillon, na Gesta Renaut de Montauban:

Sire, dist Rohart, or oiez mon pense.

Cuidez vos, emperere, de nos soient amé?

Renaut ocist mon pere par mult grant cruauté,

Et veez ci mon gage, par Deu de majesté,

Que lor pere est traïtre, ja lor sera mostré.

Et se il le desdient, vez me ci apresté

De conbatre vers els se il sunt tant osé.

(v. 13626-13632).

Os acusados não apresentam provas de sua inocência e, tal como quem acusa, fazem apenas um discurso ritual rebatendo as alegações do outro, como Aymonet faz em relação a Rohart:

Tais toi, dist il Rohart, traïtre renoiez!

La bataille en avrez, ja poor n'aiez.

Emperere de France,vez mon gage ploiez

Por defendre mon pere que tant par est proisiez,

Qu'il n'est pas traïtre, par Dieu le droiturier.

Vers li le defendrai et sel ferai iriez.

(v. 13634-13639).

Obviamente, para quem não se preocupa em trair, como é comum nos Ganelidas, o próprio procedimento acima é uma oportunidade para fazer uma traição acusando os outros barões de crimes que eles não cometeram. Feitos os discursos rituais de acusação e de defesa não cabe investigação ou questionamentos. Serão ações físicas, a luta em um duelo judicial, os meios para provar-se quem mente e quem diz a verdade, quem está em erro e quem está com o direito. Empenhar a palavra em uma afirmação utilizando o nome de Deus, como nos dois casos acima citados, era grave e, nos conceitos religiosos medievais, poderia acarretar uma punição a quem fosse mendaz, ainda mais se houvesse um combate entre as partes.

Em uma sociedade onde a coletividade está acima dos indivíduos, como no caso da sociedade feudo-vassálica e linhageira francesa dos séculos XI-XIII, são exigidos dos personagens envolvidos no processo a apresentação de garantias, ou seja, os seus parentes declaravam-se responsáveis pela apresentação do duelista no dia do combate. Depois, 
ofereciam-se como reféns, desta vez assumindo o compromisso de confirmar que quem eles caucionam dizia a verdade. Desse modo eles podiam tornar-se solidários com o acusado ou acusador e assumir o risco de serem punidos caso fosse confirmado estarem do lado do erro, como ocorreu na Chanson de Roland, com os trinta parentes de Ganelon.

O duelo judicial não era uma mera disputa na qual a força física ou a habilidade com as armas decidia o resultado. Ele era uma forma de ordálio, um meio de pedir para Deus se manifestar de modo a ser feita a justiça. Considerado justo e verdadeiro nos poemas, Deus não permitiria a vitória de quem tivesse cometido um crime ou estivesse mentindo. Se na Chanson de Roland do manuscrito de Oxford não encontramos menção ao beijo ou ao toque de relíquias, outros poemas tratam disso com muitos detalhes. $\mathrm{Na}$ Gesta Renaut de Montauban, quando do duelo dos filhos de Reinaldo com os filhos de Fouque de Morillon, os quatro jovens devem jurar estarem dizendo a verdade e beijar certas relíquias ${ }^{357}$. Os netos de Aymon fazem isso sem titubear. Já os Ganelidas, apesar de confirmarem sua acusação, não conseguem tocar as relíquias e, com isso, confirmam antecipadamente sua condição de culpados.

Embora o duelo judicial tenha uma base sagrada, dada a forma como ocorrem os seus preparativos, é frequente a poesia épica mostra-lo sendo violado. A interferência é feita sempre pelos parentes de Ganelon, mas seus resultados são muito variáveis. Renaut de Montauban, no combate entre os filhos da boa e da má linhagem, mostra a intervenção dos Ganelidas frustrada por uma rápida reação dos Aymonidas, não entrando os traidores no campo de batalha ${ }^{358}$. No poema Gaydon, o duelo entre Ferraut e Gui de Autefoille, os Ganelidas interferem na luta, atacam os guardas imperiais do campo e só não matam o sobrinho de Thierry porque havia guerreiros angevinos prontos para impedi-los de realizar seu intento ${ }^{359}$. E na Gesta Jehan de Lançon, este barão resgata o seu parente Hardré durante o combate no qual Berart de Mondidier provava ser aquele um traidor ao rei ${ }^{360}$. Em alguns casos a violação do duelo judicial era punida pelo rei, mas isso não acontecia sempre. Contando com a cobiça do rei, os Ganelidas compram a boa vontade deste e conseguem evitar a punição dos violadores ${ }^{361}$.

As Canções de Gesta costumam mostrar o final desses combates rituais como uma vitória da verdade e do direito. Os personagens que juraram em falso e/ou cometeram

\footnotetext{
${ }^{357}$ RENAUT DE MONTAUBAN, v. 13709-13744.

${ }^{358}$ Ibid., v. 13914-13966.

${ }^{359}$ GAYDON, v. 6787-6870.

360 JEHAN DE LANÇON, v. 3612-3630.

${ }^{361}$ GAYDON, v. 7599-7608.
} 
crimes e tentaram escondê-los, são derrotados pelo adversário da linhagem heróica. Por vezes a luta é difícil e demorada, os heróis recebem muitos ferimentos, mas conseguem vencer, pois na ótica do poema Deus vai sempre ajudar quem está certo e não permitirá a vitória de um criminoso ou de quem o esteja defendendo. Assim, Thierry mata Pinabel e os barões gritam ter Deus manifestado o seu poder, ao proteger o campeão do rei em uma luta igual à de Davi e Golias ${ }^{362}$. O mesmo ocorre com os filhos de Reinaldo diante dos filhos de Fouque de Morillon e de Gaydon frente à Thibaut d'Aspremont.

Mas não pensemos que um duelo não pudesse ser burlado. A poesia épica podia apresentar matizes dependendo da situação ou da falta na qual se encontre um herói. Um caso emblemático é o do duelo entre Ami e o traiçoeiro Hardres, na Canção de Ami et $A_{m i l e}{ }^{363}$. Estes dois cavaleiros do título eram amigos e fisicamente iguais, embora não fossem irmãos gêmeos. Ami se casara com uma mulher oriunda de uma linhagem infiel, a de Hardré. Amile permaneceu na corte, envolveu-se sexualmente com a filha de Carlos Magno e foi denunciado pelo traidor, devendo participar de um duelo judicial, no qual seria derrotado. Amile buscou a ajuda de Ami e este tomou o lugar do amigo no duelo. A questão do ritual corretamente feito, com as palavras proferidas de modo a corresponder exatamente aos fatos pelos quais haveria o combate foi, neste poema, conduzida de uma forma esclarecedora. Ami e Hardré estão diante do imperador, o qual manda trazer relíquias para o juramento dos combatentes. Hardré inicia o procedimento:

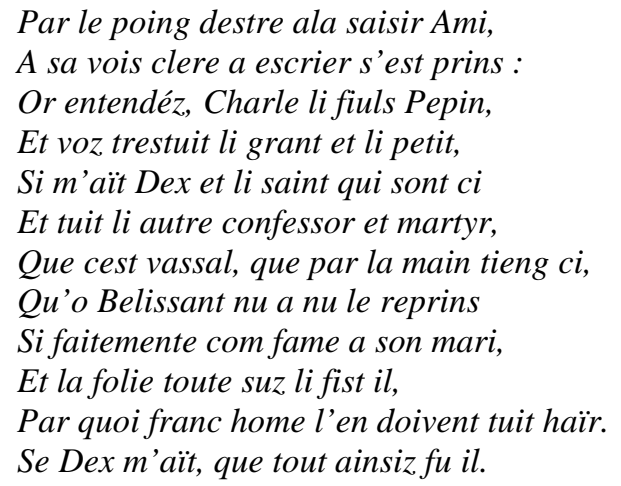

(v. 1413-1424)

O traidor pensava estar com Amile do lado, tê-lo seguro pela mão, mas não estava e quem ele acusou era inocente daquela falta e, portanto, o acusador cometera um perjúrio. Talvez

\footnotetext{
362 CHANSON DE ROLAND, v. 3931, «Escrïent Franc: Deus i ad fait vertu! ». É comum encontrarmos o termo vertu deste verso traduzido por miracle. Preferimos, de nossa parte, adotar o sentido de "força" ou "poder", seguindo a exposição de G. F. Jones, sobre essa palavra. JONES, G. F. The Ethos of the Song of Roland, p. 32.

${ }^{363}$ AMI ET AMILE. Chanson de geste publié par Peter F. DEMBOWSKI. Paris: Honoré Champion, 1987.
} 
se tivesse citado o nome de Amile o desenrolar do combate fosse diferente, mas o poeta não tinha intenção de dar uma oportunidade para o pérfido de seu poema sair vitorioso. $\mathrm{O}$ duelo foi vencido pelo herói, embora tivesse realmente havido uma falta grave contra o senhor, através da "sedução" de sua filha ${ }^{364}$. Se Ami é punido posteriormente tornando-se leproso, isso não decorreu da sua participação no combate judicial no lugar de Amile e sim por ter jurado tomar Belissenda como sua esposa, embora já casado com Lúbias. Ao incorrer no adultério Ami tornou-se passível de punição divina, conforme anunciou-lhe um anjo;

\author{
Li cuens Amis ot fait son sairement, \\ De vers le ciel vint un angres volant, \\ Desor l'espaule ami de maintenant \\ S'assist li angres, sachiéz certainnement, \\ Onques nel virent ne li rois ne sa gent. \\ Enz en l'oreille li consilla forment : \\ "Di va, Ami, com te voi nonsaichant! \\ Tu preïz fame au los de tes parans. \\ Hui jures autre, Deu en poise forment. \\ Moult grans martyres de ta char t'en atent : \\ Tu seras ladres et meziaus ausiment
} (v.1806-1817)

A vitória dos heróis nos combates judicias tinha como consequência evitar que um crime que resultara na perda de guerreiros importantes, como ocorreu em Roncesvales, ficasse impune. Ou impediriam originar-se uma injustiça, caso os traidores vencessem, como no duelo realizado pelos filhos de Reinaldo. Um complô contra o rei poderia ser descoberto ou não, dependendo de quem tivesse sucesso na luta, como no primeiro combate de Gaydon. Por representarem uma ameaça ao poder do rei ou por ameaçar a paz do reino, aqueles convictos de traição deveriam pagar caro pela sua afrontosa tentativa de criar o caos na Cristandade. Uma vez provada, a traição deveria ser punida.

Uma das questões surgidas quando se tinha o traidor nas mãos era quem deveria puni-lo. Na maioria dos casos o castigo era dado pelo rei, pois ele detinha o poder supremo e era considerado a guardião de toda justiça. Assim, Carlos Magno ordenou a execução de Ganelon na Chanson de Roland e dos falsos peregrinos Ganelidas, no Jehan de Lançon. Se os malfeitores fossem mortos no decorrer do duelo judicial, ele ordenava que os cadáveres fossem expostos, pendurados em patíbulos, como ocorre com Thibaut d'Aspremont, no Gaydon. Mas nem sempre é o monarca o traído do poema épico. No

\footnotetext{
${ }^{364} \mathrm{Na}$ verdade foi a voluntariosa filha do imperador quem enganou Amile para este dormir com ela, AMI ET AMILE, v. 612-704.
} 
Renaut de Montauban, no episódio de Montessor, os Aymonidas foram vitimas da traição de Herves de Lausanne e depois de captura-lo, não tiveram a menor compaixão dele, esquartejando-o e destruindo seu corpo através do fogo,

\begin{abstract}
Adonques fu Hervix e la place amené, A .iiii. buens chevaux qui furent abrivé ; Le traïtor ont pris si l'ont si atorné Con vos porrez oür s'entendre le volez: Et es piéz et es poinz a granz seïns noez, A chascune des menbres fu .i. cheval coplez, Toz les .iiii. chevaux ont brochiez et hastez: Iluec fu le traïtres et morz et afolez. Le mairien des arsiz ont tantost assemblez, Lors firent .i. feu faire qui tost fu alumez, Lors fu ars li traïtres et la poudre ventez.
\end{abstract} (v. 2984-2994)

A execução do traidor seguiu em parte a tradição rolandiana, com o uso do esquartejamento por meio de cavalos. Mas a cremação do cadáver e o espalhar as suas cinzas ao vento constitui um requinte particular deste poema.

Por essas observações, verificamos que a ação punitiva do monarca dava-se se houvesse um julgamento, quando um procedimento formal de justiça em uma assembleia ou corte determinava a culpa do traidor e o rei como seu representante maior tornava-se o responsável pela aplicação da pena. Já quando a punição seguia imediatamente a tentativa de traição, não era o imperador a ordenar o castigo. Além disso, como no caso dos Aymonidas em Montessor, os que foram ameaçados de ser destruídos pelo traidor não pertenciam ao séquito real.

Entretanto, quando comparamos os textos épicos com os procedimentos judiciais adotados pelos Capetíngios notamos algumas diferenças. Os monarcas franceses dos séculos XII e XIII não tinham poder suficiente para impor a pena capital a algum grande barão. Às vezes era difícil até aplicar penalidades a vassalos modestos dos domínios reais. Luís VI combateu vários castelões salteadores, mas frequentemente obrigava-os a compensar suas vítimas e não o uso da pena de morte. Luís VII fez leis pela paz extensivas a todo o reino, mas deixou aos grandes príncipes territoriais a aplicação das mesmas. Renaud de Dammartin foi um adversário difícil para Felipe Augusto e traiu a este frequentemente. Após Bouvines, Renaud foi capturado e embora Guilherme o Bretão afirme que o rei poderia tê-lo sentenciado à morte, o barão foi enviado à prisão ${ }^{365}$ na qual veio a falecer quando da ascensão de Luís IX. Aplicar a pena capital contra algum

${ }^{365}$ DUBY, G. Le dimanche de Bouvines, p. 88-91. 
aristocrata esbarrava na resistência dos outros grandes senhores do reino, pois o reconhecimento do direito de vida e morte ao rei poderia implicar no enfraquecimento dessa aristocracia. Não eram poucos os barões dispostos a recorrer às armas caso entendessem ter o seu senhor, mesmo sendo este o rei, cometido alguma injustiça com eles. Além disso, como os capetíngios tinham muita proximidade com a Igreja e havia muitos bispos e abades na condição de conselheiros reais, a condenação eclesiástica aos ordálios e ao combate judicial ganhava espaço na corte de Paris. São Luís e seus juízes negaram a Enguerrand de Couci o direito ao duelo judicial para provar não ter cometido crime ao enforcar três jovens cavaleiros que entraram sem permissão em suas terras. Seu processo foi conduzido utilizando-se testemunhas, mas a vontade do rei de punir com a morte o acusado não prosperou devido a intervenção de outros príncipes territoriais franceses.

As formas de punição na poesia épica não são muito variadas, sendo a mais difundida delas o esquartejamento, talvez tornado o mais comum por ser o castigo infligido a Ganelon na Chanson de Roland. O enforcamento também era possível, como ocorreu com os falsos peregrinos do poema Gaydon, mas não foi aplicado nos demais poemas por nós estudados. Sabemos do seu emprego na Canção Aye de Avignon, após Garnier de Nanteuil vencer o duelo contra o Ganelida Auboíno, que o acusara de planejar matar Carlos Magno $^{366}$. Em outros poemas o castigo era dado no próprio campo de batalha, onde foi feito o duelo judicial. Nestes casos os traidores morriam no decorrer da luta, como os filhos de Fouque de Morillon, na Gesta Renaut de Montauban, ou são executados pelo herói logo após terem confessado seus crimes, como Thibaut d'Aspremont, no texto do Gaydon.

Parte do castigo à traição atingia a linhagem do culpado, pois ela se tornava desonrada. As parentelas eram agrupamentos aristocráticos, ciosos de sua importância no reino, orgulhosos pela condição de senhores fundiários, de guerreiros destemidos, de conselheiros do rei. Ter um parente morto de forma vergonhosa era ver-se a si e a todos os outros membros do clã como passiveis de censura ou de escárnio dos demais barões do reino. No caso da linhagem de Ganelon, a imagem que a poesia épica passa frequentemente não é a de vergonha por terem cometido um crime o qual foi punido de forma infamante. Os Ganelidas se sentem humilhados porque falharam nos seus projetos e seus membros, pegos cometendo esses crimes, haviam sido castigados. Como ocorre no decorrer do poema Gaydon, todos os parentes de Ganelon cometem maldades e eles não

${ }^{366}$ AYE D'AVIGNON, v. 713-737. 
têm vergonha por fazerem isso. O problema estava em ser preso e punido por causa delas e era isto o que tentavam evitar.

Segundo os poemas épicos, castigar a traição era exercer uma vingança sobre alguém culpado de prejudicar seu senhor ou os seus companheiros de hoste ou mesmo os membros de sua mesma fé religiosa. Quem cometeu o crime devia obrigatoriamente pagar por ele. Mas as Canções de Gesta não colocam a responsabilidade apenas em quem executou o ato. Estendia-se muitas vezes a punição aos parentes do traidor, por terem se portado como garantia da inocência do acusado ou por instigação de membros da corte régia, temerosos de que a linhagem buscasse vingança. Isso talvez não fosse algo limitado à literatura medieval. Se a justiça era confundida com a vingança, nem sempre esta atingia o culpado por um crime, mas um parente seu. Quem aplicava a lei, se fosse punir e não tivesse o condenado nas mãos, poderia usar do princípio da solidariedade do sangue e aplicar a sansão em alguém que nada fizera, mas era da família do acusado. Quando os Coutumiers, como os da Normandia, foram escritos, tentavam deixar claro não serem os parentes puníveis pelo crime de alguém só por causa de seu sangue.

Notamos uma atenção muito grande da poesia épica para com o destino dos corpos dos traidores. Depois de mortos estes eram privados de sepultura, permanecendo seus cadáveres despedaçados espalhados no campo onde morreram, ou conduzidos a patíbulos onde ficariam expostos até apodrecerem completamente. Se esses mortos tivessem sido decapitados, impedindo de serem eles pendurados pelo pescoço, a corda era passada entre os seus braços e o tronco, para a exposição ser feita ${ }^{367}$. Havia também a destruição através do fogo e, depois de reduzido a cinzas, estas seriam espalhadas pelo vento ${ }^{368}$.

Talvez, em parte, essas descrições tenham sido trabalhadas a partir das lendas sobre a morte de Judas Iscariótis. No Evangelho de Mateus e nos Atos dos Apóstolos onde é relatada sua morte, Judas teria se enforcado e enquanto estava pendurado seu ventre rompera, espalhando suas entranhas no chão ${ }^{369}$. E a Vulgata não fala do sepultamento do Iscariótis. Há lendas nas quais se diz ter Judas vivido até bem depois da crucificação de Cristo, mas atingido pela obesidade ele teria ficado enorme e, ao passar por uma rua

${ }^{367}$ É o que ocorre com Thibaut d'Aspremont, no Gaydon, decapitado por Thierry após este vencer o duelo judicial.

${ }_{368}$ Herves de Lausanne, no Renaut de Montauban.

${ }^{369}$ MATEUS, 27: 5, cita apenas do enforcamento. ATOS, 1:16-19, fala do enforcamento e do rompimento do ventre. 
estreita, foi esmagado por uma carroça por não ter como desviar-se dela ${ }^{370}$. A destruição do corpo do traidor é uma constante nas Canções de Gesta e esse destino acabou sendo repassado para outros indivíduos ou personagens responsabilizados por crimes semelhantes ou associados ao do Iscariótis.

Uma das explicações para a proliferação desse tipo de castigo aos traidores possivelmente decorresse da crença cristã na ressurreição da carne quando da chegada do fim dos tempos e da segunda vinda do Cristo, para julgar os homens e premiá-los ou punilos pela eternidade. Na tradição cristã a preservação do corpo para esse evento era muito importante, pois sobre o esqueleto do falecido ressurgiria a carne desaparecida pela ação da decomposição, dos vermes e dos animais, e ele se levantaria para ir ao julgamento final. Daí a necessidade dos mortos descansarem em locais seguros, de serem acumulados seus restos mortais em ossuários ou, para os mais ricos e importantes dos homens, serem sepultados perto dos restos dos santos, de suas relíquias, para que intercedessem por eles.

No pensamento cristão medieval, destruir o corpo de alguém era uma tentativa de impedir a sua ressurreição, pois privado de um corpo material não seria possível dela ocorrer. Tal pena era aplicada aos crimes considerados mais graves, como o infanticídio, o canibalismo, a sodomia. Os hereges e apóstatas também eram castigados pelo fogo como punição por renegarem a Divindade e negarem o Seu poder na terra. Ao se destruir o corpo físico dessa forma, condenava-se antecipadamente o culpado morto a arder no fogo do Inferno. Para o queimado não haveria julgamento, pois ele já fora julgado e condenado quando lançado, vivo ou morto, no fogo. Aos traidores, por todas as características que o ligavam a Judas Iscariótis, aos que renegavam a fé, aos que cometiam sacrilégio conspirando contra um senhor imposto por Deus, aos que ameaçavam a estabilidade do cosmos criado e ordenado pela Divindade, todos estes mereceriam, na visão cristã medieval, um castigo capaz de fazê-los desaparecer fisicamente e não terem a oportunidade de retornarem a este mundo, mesmo no fim dos tempos.

Podemos contrapor ao destino dos corpos dos traidores, a sorte reservada aos restos mortais dos heróis épicos, conservados como verdadeiras relíquias, segundo os jograis. Assim, Rolando, Olivier e Turpin descansavam em sarcófagos na igreja de Saint-Romain, em Blaye, e podiam ser vistos pelos peregrinos. Reinaldo de Montauban, de guerreiro passara a eremita e, depois, tornara-se um servente de pedreiro em Colônia, onde seria

${ }^{370}$ CABROL, D. F.; LECLERCQ, D. H. Dictionnaire d'archéologie chrétienne et de liturgie, T-VIII, Judas Iscariote, p. 259-264. HASTINGS, James. A Dictionary of the Bible. Edinburgh : T. \& T. Clark, 1900 , Vol. II, p. 797-798. 
martirizado. Os seus assassinos tentaram desaparecer com seu corpo, jogando-o no rio Reno, mas os peixes não deixaram a correnteza o levar ${ }^{371}$. Recuperado e honrado, esse corpo ainda conduziria a carroça que o levava ao cemitério para Tremoine, onde ele queria ser enterrado e venerado ${ }^{372}$.

${ }^{371}$ RENAUT DE MONTAUBAN, v. 14205-14255.

${ }^{372}$ Ibid, v. 14268-14305. 


\section{CONCLUSÃO}

A traição foi uma preocupação constante para os homens do medievo, em especial para os de suas camadas superiores e dirigentes. A organização das relações de poder político e de posse territorial envolvia a existência de relações pessoais entre os membros da aristocracia entre si e para com um personagem superior, o rei. Essas relações baseavam-se na fidelidade jurada, na qual os contratantes prometiam-se não prejudicar um ao outro e a ajudarem-se mutuamente. A violação desses acordos ameaçava não apenas quem era traído, mas também todo o arcabouço que sustentava essa sociedade. E a religião cristã dominante nesta sociedade tinha seu evento fundador numa traição feita por um discípulo ao seu Mestre, ato relembrado anualmente quando das festas da Páscoa e da ressurreição do Cristo. Além disso, o próprio termo designativo do crime foi extraído dos livros sagrados, dos Evangelhos, e superara todas as demais palavras passíveis de ser seu sinônimo.

As Canções de Gesta, gênero literário surgido e difundido do século XI ao século $\mathrm{XV}$, por se tratarem de poemas voltados ao entretenimento de uma aristocracia cavaleiresca, apresentavam em suas narrativas as representações de mundo desse público e mudavam seus enredos de acordo com as alterações nas concepções e gostos desse grupo. Coetânea a elas, a monarquia capetíngia (987-1328) enfrentara um período de fraqueza diante dos grandes senhores territoriais, até o início do século XII. A partir de então, paulatinamente foi readquirindo força e poder para sobrepujar a aristocracia senhorial até então quase independente. Há uma aceleração desse processo desde 1180 e, paralelamente, as Canções de Gesta sofrem alterações que afetam principalmente as relações idealizadas entre os vassalos e seu rei. Assim, a luta contra o distante Carlos Magno e a traição passaram a ser os temas dominantes dessa literatura.

A Chanson de Roland (c. 1100) mostrava Carlos Magno como um rei respeitado por seus vassalos, orientado por anjos mandados por Deus, mas incapaz de evitar desastres por respeitar muito as assembleias de barões. Girart de Vienne de Bertrand de Bar-surAube (1180-83) apresenta-se como uma obra intermediária e, reconhecendo alterar lendas anteriores, o autor faz do antigo vassalo descumpridor de suas obrigações um vassalo modelo de fidelidade, mas obrigado a lutar contra seu senhor por culpa deste. Renaut de Montauban e Gaydon (primeira metade do século XIII) fazem de Carlos Magno um 
personagem por vezes injusto, vingativo, esquecido das obrigações régias de manter a paz e a justiça, e influenciável por um grupo de traidores encastelados na corte. Se a luta dos filhos de Aymon e de Thierry é justificada nestes poemas, na metade do século XIII, com Jehan de Lançon, vemos um poeta defender a necessidade de submissão de todos os príncipes cristãos ao imperador de Paris. E aquele que ousasse desafiá-lo acabaria derrotado e condenado a prisão. A poesia épica tomara um sentido contrário ao das transformações verificadas com a monarquia capetíngia na França, de 1180 a 1328, pois neste período os Capetos venceram os grandes senhores territoriais, em especial os Plantagenetas, passaram a interferir na administração e justiça dos senhorios, aumentaram seus recursos humanos, militares e financeiros, sobrepujando todos os outros potentados franceses. As Canções de Gesta, no momento de fortalecimento capetíngio, passaram a censurar o rei épico que abusava de seu poder, mostrando como heróis cavaleiros em luta contra o monarca. Mas ao mesmo tempo elas defenderam a fidelidade e o respeito para com a pessoa desse rei e a busca do seu perdão, pois a condução do reino, de acordo com a vontade de Deus, exigia a presença da figura régia como governante máximo.

Para justificar a luta do vassalo contra seu senhor a poesia épica difundiu a ideia da injustiça do rei para com seu "homem". Este não era um traidor, pois estava defendendo sua honra e a de sua linhagem. Esse vassalo injustiçado respeita sempre a pessoa do monarca, evita atacá-lo ou feri-lo e demonstra contínua disposição para pedir o perdão régio e o seu retorno à corte, deixando ao seu senhor a escolha de uma penitência para purgar suas ações durante a luta. Esse vassalo não aceita ser punido pela sua resistência, pois uma punição só atinge quem fosse culpado de algum crime ou falta. Portanto o papel de traidor recai em outros personagens, estando estes filiados ao clã dos Ganelidas e este só começou a ser esboçado no final do século XII e início do XIII.

Ganelon, seu patrono, na Chanson de Roland agira individualmente para cometer sua traição. Se sua parentela também foi punida, isso se deveu a darem mais importância à defesa de um de seus membros, sendo este um traidor. Renaut de Montauban, Gaydon e Jehan de Lançon manifestam uma transformação importante, fazendo a linhagem Ganelida comportar-se como infiel e traidora diante do rei e dos demais barões do reino. A traição deixava de ser um crime individual para ser uma conjuração, o ato planejado por um grupo visando obter alguma vantagem ou vingança ou, mais grave, matar seu senhor e tomar a coroa da França. Para os poetas e jograis, cometer esse crime não era mais uma decisão do indivíduo e sim uma propensão herdada através do sangue da linhagem, algo do qual seus membros não podiam eximir-se de realizar, pois trair fazia parte da sua natureza. 
Como a traição era um ato orquestrado às escondidas e envolvia dissimulação, prová-la em uma corte de justiça era difícil, ainda mais quando essa corte se baseava em declarações de acusadores e acusados e deixava a decisão do certo e do errado para um duelo, onde a Divindade deveria dar o veredicto. Tais procedimentos, básicos nos textos épicos, estavam sendo contestados, no século XIII, primeiro pela Igreja e depois pelos próprios monarcas, como Luís IX, pois estes viam nos combates judiciais uma tentação a Deus. A poesia, representando um passado glorioso em suas narrativas, reafirmava o valor desse tipo de prova, não permitindo a vitória de um traidor e, assim, rejeitava as transformações na forma de condução dos julgamentos na corte de Paris ou nas cortes senhoriais, conduzidos por pessoal formado em faculdades de direito e baseando suas decisões em provas e testemunhos.

Se houve contestação quanto às formas de julgar os crimes, a visão de como seria a punição por crimes graves como a traição na poesia épica era idêntica à da sociedade onde ela circulou. Quem fosse culpado deveria pagar com a vida, mas as Canções de Gesta desenvolvem narrativas de execução, enquanto para os monarcas Capetos, pelo menos até Felipe o Ousado, era difícil aplicar a pena capital a um aristocrata, pois os outros membros da aristocracia procurariam impedir essa punição, limitando as condenações à prisão perpétua de um Renaud de Dammartin ou às pesadas compensações feitas por Enguerrand de Couci. Já a crença cristã na ressurreição no final dos tempos levou à descrição épica da destruição do corpo do criminoso através do fogo ou a privação de sepultura, ficando o cadáver exposto até estar completamente decomposto. Estes procedimentos não eram apenas ficção literária, sendo aplicadas com frequência e não se limitava apenas ao crime de traição, fosse nos diversos senhorios ou mesmo na corte régia, especialmente com relação aos hereges.

Vemos, portanto, que as Canções de Gesta se apresentam como fontes privilegiadas para o estudo não apenas da traição, mas também de outras representações do ideal político na França do período em que foram compiladas. A poesia épica, além disso, mostra como determinadas ideias são suplantadas quando alterações afetaram as relações de poder na sociedade onde ela era cantada ou recitada. Mas tais alterações deveriam respeitar os dois personagens da luta política no reino da França. De um lado mostrar de modo favorável os vassalos em luta contra o rei, para agradar os senhores territoriais interessados nos poemas e remuneradores de poetas e jograis. Do outro lado, manter o respeito pela instituição monárquica mesmo fazendo em seus versos o monarca adquirir características negativas. A criação da linhagem dos traidores ajudaria nesse sentido, pois, afinal de contas, são eles 
que trabalham para o desentendimento entre o bom vassalo e seu senhor. Eliminando-se os traidores da corte, a desavença acabava e o reino podia ser gerido em harmonia pelo rei e seus bons vassalos, haveria paz e a justiça voltaria a ser distribuída, conforme os ditames do agostinismo político.

As Canções de Gesta não influenciaram no fortalecimento político da monarquia capetíngia, pois há sérias dúvidas de que fossem recepcionadas nas cortes régias, onde a sobriedade clerical dominava. As narrativas épicas eram feitas para divertir ou distrair as pessoas, em especial os membros da ordem cavaleiresca, os mais interessados em ouvir as histórias das guerras de seus antepassados francos. Mas, para serem aceitas, as Canções deviam apresentar elementos de fácil entendimento para o seu público e adaptar-se às mudanças ocorridas na sociedade e nos meios onde elas circulavam. Assim, elas falavam de reis poderosos ou injustos, da luta contra os sarracenos ou entre um senhor e seus vassalos, levantavam problemas de justiça, pregavam uma sociedade idealizada com base nas relações feudo-vassálicas, onde a aristocracia cavaleiresca tinha um papel capital junto ao seu monarca. A poesia épica francesa era uma representação ligada aos anseios de um mundo laico e aristocrático, no qual as grandes linhagens tinham um papel a ser cumprido apoiando um rei cuja existência era necessária para conduzir o reino com segurança. Essa representação, a partir de 1180, chocou-se com uma realidade de fortalecimento da monarquia capetíngia em detrimento dos grandes senhores territoriais. Não podendo ou não querendo tomar uma posição clara, as Canções passaram a elogiar os "vassalos rebeldes", mas sem perder de vista que, no final, estes e o rei contra o qual lutavam deveriam firmar a paz e viver em concordância. Do mesmo modo, a aristocracia francesa do final do século XII e do século XIII, após muitas revoltas inúteis, teve que concordar com uma submissão maior ao monarca capetíngio. E é neste ponto que a poesia épica pode ser relacionada com o fortalecimento da realeza. 


\section{BIBLIOGRAFIA}

\section{Fontes}

AGOSTINHO (Santo). A cidade de Deus. Petrópolis: Vozes, 2 Volumes, $2^{\text {a }}$ edição, 1990.

AMI ET AMILE. Chanson de geste publié par Peter F. DEMBOWSKI. Paris: Honoré Champion, 1987.

BEUVE DE HAMPTONE. Chanson de geste anglo-normande de la fin du XIIe siècle. Édition bilingue. Publication, traduction, présentation et notes par Jean-Pierre MARTIN. Paris : Honoré Champion, 2014.

BERTRAND DE BAR-SUR-AUBE. Girart de Vienne, publié par Wolfgang VAN EMDEN. Paris: A. e J. Picard, 1977.

BIBLIA SACRA IUXTA VULGATA CLEMENTINAM. Nova editio: Alberto COLUNGA O.P. et Laurentio TURRADO. Matriti: Biblioteca de Autores Cristianos, $10^{\mathrm{a}}$ editio, 1999.

BÍBLIA SAGRADA. Tradução da Vulgata pelo Pe. Matos SOARES. SP: Paulinas, 1989.

CHANSON DE ROLAND (La). Édition critique et traduction de Ian SHORT. Paris: Libr. Générale Française; Le Livre de Poche, 1990.

CHANSON DE ROLAND (La). Édition critique par Cesare SEGRE. Genève: Droz, 2 tomes, 1989.

CHANSON DE ROLAND (La) / The Song of Roland, The French Corpus. General editor Joseph J. DUGGAN. Turnhout (Belgium): Brepols, 3 vols, 2005.

CHANSON DES QUATRE FILS AYMON (La). D'après le manuscrit La Vallière, par Ferdinand CASTETS. Genève: Slatkine, 1974.

CÍCERO. As Catilinárias. SP: Martin Claret, 2006.

CODEX THEODOSIANUS. Disponível em http://koeblergerhard.de/Fontes/Codex Theodosianus438.htm. Acessado em 24/08/2014.

CORPUS IURIS CIVILIS. Volumen Primum. Institutiones, recognovit Paulus Krueger. Digesta, recognovit Theodorus Mommsen, retractavit Paulus Krueger. Berolini, Weidmannos, 1893.

COURONNEMENT DE LOUIS (Le). Chanson de geste du XIIe. siècle, éditée par Ernest LANGLOIS. Paris: Champion, 1984, 2e. édition. 
COUTUMIERS DE NORMANDIE. Tome I: Le très ancien coutumier de Normandie, texte latin, publié par Ernest-Joseph TARDIF. Rouen : Espérance Cagniard, 1881.

COUTUMIERS DE NORMANDIE. Tome I: Le très ancien coutumier de Normandie, textes français et Normand, publiés par Ernest-Joseph TARDIF. Rouen : A. Lestrigant ; Paris : A. Picard et Fils, 1903.

COUTUMIERS DE NORMANDIE. Tome II: La Summa de legibus Normannie in curia laicali. Textes critiques publiés par Ernest-Joseph TARDIF. Rouen: A. Lestringant ; Paris : A. Picard et Fils, 1896.

DOON DE MAIENCE, Chanson de Geste. Publiée pour la premiére fois d'après les manuscrits de Montpellier et de Paris par M. A. PEY. Paris : F. Vieweg, 1859.

ÉTABLISSEMENTS DE SAINT LOUIS (Les). Publiées par Paul VIOLET. Paris : Renouard, Tome I, 1881 ; Tomes II et IV, 1886.

FIERABRAS. Chanson de geste du XIIe siècle. Éditée par Marc LE PERSON. Paris: Champion, 2003.

GALBERT DE BRUGES. Histoire du meurtre de Charles le Bon, Comte de Flandre (1127-1128), suivie de poésies latines contemporaines. Publiées par Henri PIRENNE. Paris: Alphonse Picard, 1891.

GALBERT OF BRUGES. The Murder of Charles the Good. Translated and Edited by James Bruce ROSS. Toronto: University of Toronto Press, 1993.

GAUFREY, chanson de geste. Publiée pour la première fois d'après le manuscrit unique de Montpellier par MM. F. GUESSARD et P. CHABAILLE. Paris : Vieweg, 1859.

GAYDON, chanson de geste. Publiée pour la première fois d'après les trois manuscrits de Paris, par F. GUESSARD et S. LUCE. Paris: A. Franck, 1872.

GRÉGOIRE DE TOURS. Histoire des Francs, Livres I-VI. Texte du manuscrit de Corbie, Bibliothèque Nationale, ms. Lat. 17665. Publié par Henri OMOUT. Paris: Alphonse Picard, 1886.

GRÉGOIRE DE TOURS. Histoire des Francs, Livres VII-X. Texte du manuscrit de Corbie, Bibliothèque Naitonale, ms. Lat. 17665. Publié par Gaston COLLON. Paris: Alphonse Picard et Fils, 1893.

GRÉGOIRE DE TOURS. Histoire des Francs. Traduite du latin par Robert LATOUCHE. Paris: Les Belles Lettres, 1999.

GUI DE BOURGOGNE, chanson de geste. Publiée pour la première fois d'après les manuscrits de Tours et de Londres par MM. F. GUESSARD et H. MICHELANT. Paris : Vieweg, 1859. 
GUIBERT DE NOGENT. Autobiographie. Introduction, édition et traduction par EdmondRené LABANDE. Paris: Les Belles Lettres, 1981.

GUILLAUME DE POITIERS. Histoire de Guillaume le Conquerant. Éditée et traduite par Raymond FOREVILLE. Paris: Les Belles Letres, 1952.

HUGUES CAPET. Chanson de geste du XIV siècle. Editée par Noëlle LABORDERIE. Paris : Honoré Champion, 1997.

HUON DE BORDEAUX. Édition biligue établie, traduite, présentée et annotée par William W. KIBLER et François SUARD. Paris: Honoré Champion, 2003.

IRENEU DE LIÃO. Contra as heresias. SP: Paulus, 1995.

JEAN BODEL. La chanson des Saisnes. Édition critique par Annette BRASSEUR, Genève: Droz, 2 vols., 1989.

JEHAN DE LANÇON. Chanson de geste du XIIIe siècle. Publiée par Jean DUPLESSY. Paris: Le Léopard d'Or, 2004.

JOINVILLE. Vie de Saint Louis. Texte établi, traduit, présenté et annoté par Jacques MONFRIN. Paris : Garnier, 1995.

MAINET, fragments d'une chanson de geste du XIIe siècle. Par Gaston PARIS. Romania, T-IV, 1875, p. 305-337.

PHILIPPE DE BEAUMANOIR. Coutumes de Beauvaisis. Texte critique publié par Am. SALMON. Paris: T-I, Alphonse Picard et Fils, 1899; T-II, A. et J. Picard, 1970.

PHILIPPE MOUSKES. Chronique rimée. Publiée par le Baron de Reinffenberg. Bruxelles : M. Hayez, T-I, 1836 ; T-II, 1838.

RAOUL DE CAMBRAI. Chanson de geste du XIIe siècle. Introduction, notes et traduction de William KIBLER. Texte édité par Sarah KEY. Paris : Le livre de poche, 1996.

RENAUT DE MONTAUBAN. Édition critique du manuscrit Douce par Jacques THOMAS. Genève: Droz, 1989.

RICHER. Histoire de France (888-995). Éditée et traduite par Robert LATOUCHE. Paris : Les belles lettres, 1964.

ROLAND OCCITAN (Le). Roland à Saragosse; Ronsasvals. Édition et traduction de Gérard GOUIRAN et Roberte LAFONT. Paris : Christian Bourgois, 1991.

SAGA DE CHARLEMAGNE (La). Traduction, notices, notes et index par Daniel W. LACROIX. Paris: Le Livre de Poche, 2000.

SUGER. Vie de Louis VI le Gros. Éditée et traduite par Henri WAQUET. Paris : Les belles lettres, 2007. 
VIVIEN DE MONBRANC. Chanson de geste du XIIIe siècle. Editée par Wolfgang VAN EMDEN. Genève : Droz, 1987.

VOYAGE DE CHARLEMAGNE À JÉRUSALEM ET À CONSTANTINOPLE (Le). Texte publié par Paul AEBISCHER. Genève: Droz, 1965.

\section{Obras de Apoio}

CABROL, D. F.; LECLERCQ, D. H. Dictionnaire d'archéologie chrétienne et de liturgie. Paris : Letouzey et Ané, T-VIII, prémière partie, 1928.

CALMETTE, Joseph. Atlas historique, II - Le Moyen Age. Paris : PUF, 1959.

GODEFROY, Frédéric. Dictionnaire de l'ancienne langue française et de tous sés dialectes du IXe au XVe siècle. Paris : Librairie des sciences et des arts, T-III, 1938.

GAUVARD, Claude; DE LIBERA, Alain; ZINK, Michel. Dictionnaire du Moyen Âge. Paris: PUF, 2002.

GREIMAS, A.-J. Dictionnaire de l'ancien français jusqu'au milieu du XIVe. siècle. Paris: Larousse, 1986.

HASTINGS, James. A Dictionary of the Bible. Edinburgh : T. \& T. Clark, Vol. II, 1900.

LANGLOIS, Ernest. Table des noms propres de toute nature compris dans les chansons de geste imprimées. Paris: Émile Bouillon, 1904.

LE GOFF, J. e SCHMITT, J.-C. Dicionário temático do Ocidente medieval. Bauru: Edusc; SP: Imprensa Oficial do Estado, 2 vols., 2002.

\section{Bibliografia Referenciada}

AEBISCHER, Paul. Rolandiana et Oliveriana. Genève : Droz, 1967.

Trois personnages em quête d'auteurs: Roland, Olivier, Aude. In :

Rolandiana et Oliveriana. Genève : Droz, 1967, p. 141-173.

ARIAS, Ademir Aparecido de Moraes. A traição na canção de gesta Renaut de Montauban: herança neotestamentária, ética cavaleiresca e evolução política no reino da França no século XIII. 2005, 125 f. Dissertação (Mestrado em História Social) - Faculdade de Ciências e Letras de Assis, Universidade Estadual Paulista - UNESP. Assis, 2005.

ARQUILLIÈRE, H.-X. L'Augustinisme politique: essai sur la formation des théories politiques du Moyen Age. Paris: Vrin, 1972, 2e. édition. 
BARTHÉLEMY, Dominique. L'État contre le "Lignage": un thème a développer dans l'histoire des pouvoirs en France aux XIe, XIIe et XIIIe siècles. Médiévales, $\mathrm{n}^{\circ}$ 10, 1986, p. 37-50.

Nouvelle histoire des Capétiens - 987-1214. Paris : Seuil, 2012.

BÉDIER, Joseph. Les légendes épiques. Recherches sur la formation des Chansons de Geste. Paris: Honoré Champion, 4 Tomes, 1908-1913.

BELLAMY, J. G. The Law of Treason in England in the Later Middle Ages. Cambridge: Cambridge University Press, 2004.

BENEDICT, Ruth. O crisântemo e a espada. Padrões da cultura japonesa. SP: Perspectiva, $2^{a}$ edição, 1997, p. 188-190.

BILlORÉ, Maïté; SORIA, Myiriam (Direction). La trahison au Moyen Age. De la monstruosité au crime politique (Ve-XVe siècle). Rennes : Presses Univesitaires de Rennes, 2009.

BLOCH, G. La République romaine. Conflits politiques et sociaux. Paris: Ernest Flammarion, 1913.

BLOCH, Marc. Les formes de la rupture de l'hommage dans l'ancien droit féodal. In: 206. . Mélanges historiques. Paris: Serge Fleury; Éditions de l'EHESS, T-I, 1983, p.189-

La société féodale. Paris : Albin Michel, 1994.

BOISSONNADE, P. Du nouveau sur la Chanson de Roland. Paris: Ancienne Honoré Champion, 1923.

BOUREAU, Alain. De la félonie à la haute trahison. In. Le genre humain, 16-17: La trahison. Paris : Seuil, 1988, p. 267-291.

BOURIN-DERRUAU, Monique. Temps d'équilibres, temps de ruptures: XIIIe siècle. Paris: Seuil, 1990.

BOURNAZEL, Éric. Louis VI le Gros. Paris : Fayard, 2007.

BOUTARIC, Edgard. Saint Louis et Alfonse de Poitiers. Paris: Henri Plon, 1870.

BOUTET, Dominique. Les chansons de geste et l'affermissement du pouvoir royal (11001250). Annales ESC, 1982, nº 1, p. 3-14.

Formes littéraires et conscience historique aux origines de la littérature française, 1100-1250. Paris: PUF, 1999.

1119-1130.

La politique et l'histoire dans les chansons de geste. Annales ESC, 1976, nº 6, p. 
BOUTRUCHE, Robert. Seigneurie et féodalité. Paris : Aubier, 2 Tomes,1970

BRÜHL, Carlrichard. Naissance de deux peuples. Français et Allemands (IXe-XIe siècle). Paris: Fayard, 1994.

BURGER, André. Turold, poète de la fidélité. Genève : Droz, 1977.

BOURQUELOT, Félix. Recherches sur les opinions et la législation en matière de mort volontaire pendant le Moyen Age. Bibliothèque de l'école des chartes. T-III, 1841-1842, p. 539-560; T-IV, 1842-1843, p. 242-266, 456-475.

CASAGRANDE, Carla; VECCHIO, Silvana. Histoire des péchés capitaux au Moyen Age. Paris: Aubier, 2003.

CLEJ, Alina. Le miroir du Roi. Une réflexion sur la Chanson de Roland. Romance Philology, vol. XLIV, 1990, nº 1, p. 36-53.

COLLARD, Franck. Le crime de poison au Moyen Age. Paris: PUF, 2003.

CRIME DE L'OMBRE (Le). Complots, conspirations et conjurations au Moyen Âge. Sous la direction de Corinne LEVELEUX-TEIXEIRA et Bernard RIBÉMONT. Paris: Klincksieck, 2010.

CUTTLER, S. H. The Law of Treason and Treason Trials in Later Medieval France. Cambridge: Cambridge University Press, 1981.

DANIÉLOU, Jean; MARROU, Henri: Nova história da Igreja. I- Dos primórdios a São Gregório Magno. Petrópolis: Vozes, $3^{\mathrm{a}}$ edição, 1984, p. 256-259.

DAUZAT, Pierre-Emmanuel. Judas, de l'Evangile à l'Holocauste. Paris: Perin, 2008.

DEMURGER, Alain. Temps de crises, temps d'espoirs, XIVe-XVe siècle. Paris : Seuil, 1990.

DESSAU, Adalbert. L'idée de la trahison au moyen âge et son rôle dans la motivation de quelques chansons de geste. Cahiers de civilisation médiévale, T-9, 1960, nº 1, p. 23-26.

DHONDT, Jean. Une mentalité du douzième siècle. Galbert de Bruges. Revue du Nord, TXXXIX, 1957, p. 101-109.

DUBY, Georges. O cavaleiro, a mulher e o padre. O casamento na França feudal. Lisboa: Dom Quixote, 1988.

Le dimanche de Bouvines. Paris: Gallimard, 1985.

DUBY, Georges.. Les “jeunes” dans la société aristocratique dans la France du Nord-Ouest au XIIe siècle. In : Féodalité. Paris : Gallimard, 1996, p. 1383-1397. 
ENTRE ÉPOPÉE ET LÉGENDE: Les quatre fils Aymon ou Renaut de Montauban. Études publiées sous la direction de Danielle QUÉRUEL. Langres - Saint-Geosmes: Dominique Guéniot, 2 vol., 2000.

FABRE, Claudiane. Deux planctus rythmiques em latin vulgaire du IXe siècle: I. Sur la bataille de Fontenoy (841). II. Sur le meurtre du sénéchal Alard (878). In: CHANSON DE GESTE ET LE MYTHE CAROLINGIEN. Mélanges René Louis, publiés par ses collègues, ses amis et ses élèves à l'occasion de son $75^{\mathrm{e}}$ anniversaire. Saint-Père-sousVézelay: Musée Archéologique Régional, Tome I, 1982, p. 177-252.

FARAL, Edmond. Les jongleurs en France au Moyen Âge. Genève : Slatkine, 1987.

FAVIER, Jean. Um roi de marbre. Philippe le Bel. Enguerran de Marigny. Paris : Fayard, 2005 .

FAWTIER, Robert. La Chanson de Roland. Étude historique. Paris: Boccard, 1933.

FÉLONIE, TRAHISON, RENIEMENTS AU MOYEN AGE. Actes du troisième colloque international de Montpellier, Université Paul-Valéry (24-26 novembre 1995). Montpellier: Cahiers du C.R.I.S.I.M.A., 1997.

FERREIROS, Aquilino Iglesia. Historia de la traición. La traición regia en León y Castilla. Santiago de Compostela: Univ. de Santiago de Compostela, 1971.

FINLEY, Moses I. Política no mundo antigo. Lisboa: Edições 70, 1997.

FLORI, Jean. L'Essor de la chevalerie: XIe.-XIIe. siècles. Genève: Droz, 1986.

Philippe Auguste. La naissance de l'État monarchique. Paris : Tallandier, 2007. Richard Coeur de Lion. Le roi-chevalier. Paris: Payot, 1999.

GAIFFIER, Baudouin de. La légende de Charlemagne. Le péché de l'empereur et son pardon. In: Recueil de travaux offerts a M. Clovis Brunel. Paris: Bibliothèque de l'École des Chartes, 1955, T-I, p. 490-503.

GANSHOF, F.-L. Qu'est-ce que la féodalité? Paris: Tallandier, 1982.

GAUTIER, Léon. Les épopées françaises. Étude sur les origines et l'histoire de la littérature nationale. Paris: T-I, Société Générale de Librairie Catholique, 2e édition, 1878; T-II, Librairie Universitaire H. Welter, 1894; T-III, Paris: Société Générale de Librairie Catholique, 1880; T-IV, Paris: Société Générale de Librairie Catholique, 1882.

L'Idée politique dans les chansons de geste. Revue des questions historiques, TVII, 1869, p. 79-114.

GERARD, Alb. L'axe Roland-Ganelon: valeurs em conflit dans la Chanson de Roland. Le Moyen Age, T-LXXV, 1969, nº 3-4, p. 445-465.

GOBRY, Ivan. Charles IV le Bel, 1322-1328. Paris: Pygmalion, 2011 
. Henri Ier., 1031-1060. Paris: Pygmalion, 2008.

Louis X, 1314-1316. Paris: Pygmalion, 2010.

Philippe Ier., 1060-1108. Paris: Pygmalion, 2006.

Philippe V, 1316-1322. Paris: Pygmalion, 2010

GRABOIS, Aryeh. De la trêve de Dieu à la paix du roi. Étude sur les transformations du mouvement de la paix au XIIe. siècle. In: Mélanges offerts à René Crozet, edités par Pierre GALLAIS et Yves-Jean RIOU. Poitiers: Société d'Études Médiévales, 1966, Tome I, p. 585-596.

HAIDU, Peter. The Subject of Violence. The Song of Roland and the Birth of the State. Bloomington; Indianapolis: Indiana University Press, 1993.

HALPHEN, Louis. Charlemagne et l'empire carolingien. Paris : Albin Michel, 1979.

HALVERSON, John. Ganelon's Trial. Speculum, Vol. 42, 1967, nº 4, p. 661-669.

HOLLYMAN, K.-J. Le développement du vocabulaire féodal pendant le haut Moyen Age. Genève : Droz ; Paris : Minard, 1957.

HORRENT, Jules. La bataille des Pyrénées de 778. Le Moyen Age, T-LXXVIII, 1972, n $^{\circ}$ 2, p. 197-227.

HUNT, Tony. L'inspiration idéologique du Charroi de Nîmes. Revue belge de philologie et d'histoire. T-LVI, 1978, no 3, p. 580-606.

JONES, George Fenwick. The Ethos of the Song of Roland. Baltimore: Johns Hopkins Press, 1963.

KELLER, Hans-Erich. Autour de Roland. Recherches sur la chanson de geste. Paris: Champion, 1989.

KRAUSS, Henning. Aspects de l'histoire poétique de Charlemagne en Italie. In: CHARLEMAGNE ET L'ÉPOPÉE ROMANE. Actes du VIIe Congrès International de la Société Rencesvals. Liège, 28 août - 4 septembre 1976, Tome I. Paris : Les Belles Lettres, 1978, p. 103-123.

LAFONT, Robert. La Geste de Roland. Paris : L'Harmattan, 2 Tomes, 1991.

Les origines occitanes de la chanson de geste: le cas de $\underline{\mathrm{F}(\mathrm{i}) \text { erabras. }}$ Cahiers de civilisation médiévale, T-41, 1998, p. 365-373.

LANGLOIS, Charles-Victor. Saint Louis, Philippe le Bel, les derniers Capétiens directs (1226-1328). Paris : Tallandier, 1978. 
LE GENTIL, Pierre. Girard de Roussillon, sens et structure du poème. Romania, T-78, 1957, p. 328-389; 463-510.

Ogier le Danois, héros épique. Romania, T-78, fasc. 310, 1957, nº 2, p. 199-233.

LEAR, Floyd Seyward. Treason in Roman and Germanic Law. Collected Papers. Austin: University of Texas Press, 1965.

LEMOSSE, Maxime. La lese-majesté dans la monarchie franque. Revue du moyen âge latin, T-2, 1946, p. 5-24.

LOT, Ferdinand. Études sur les légendes épiques françaises. Paris: Honoré Champion, 1970.

LOUIS, René. De la légende à la histoire: Girart, comte de Vienne dans les chansons de geste. Auxerre: Aux Bureaux de l'Imprimerie Moderne, 3 vols., 1947.

LUCHAIRE, Achille. Philippe Auguste et son temps. Paris : Tallandier, 1980.

Les premiers Capétiens (987-1137). Paris : Tallandier, 1980.

MARKSCHIES Christoph. Estructuras del cristianismo antiguo. Un viaje entre mundos. Madrid: Siglo Veintiuno, 2001, p. 95-96.

MENANT, François; MARTIN, Hervé; MERDRIGNAC, Bernard; CHAUVIN, Monique. Les Capétiens, 987-1328. Paris : Perrin, 2008.

MENÉNDEZ-PIDAL, Ramón. La Chanson de Roland et la tradition épique des Francs. Paris: A. et J. Picard, 1960, 2e. édition.

MICKEL, Emanuel J. Ganelon, Treason, and the "Chanson de Roland". Pennsylvania State University Press, 1989.

MISRAHI, Jean. Girard de Vienne et la geste de Guillaume. Médium Aevum. Vol. IV, 1935, no 1, p. 1-15.

MORRISSEY, Robert. L'Empereur à la barbe fleurie. Charlemagne dans la mythologie et l'histoire de France. Paris: Gallimard, 1997.

PAGANO, Mario. Encore quelques rotules sur les versions $\mathrm{D}$ e $\mathrm{L}$ du Renaut de Montauban. In : ENTRE ÉPOPÉE ET LÉGENDE: Les quatre fils Aymon ou Renaut de Montauban. Études publiées sous la direction de Danielle QUÉRUEL. Langres - SaintGeosmes: Dominique Guéniot, Vol. I, 2000, p. 169-181.

PARIS, Gaston. Histoire poétique de Charlemagne. Paris: A. Franck, 1865.

PAUPHILET, Albert. Sur la Chanson d'Isembart. Romania, T-50, 1924, p. 161-194.

PETIT-DUTAILLIS, Charles. La monarchie féodale en France et en Angleterre. Paris : Albin Michel, 1971. 
POLLET, Jean-Jacques; SYS, Jacques. Figures du traître. Les représentations de la trahison dans l'imaginaire des lettres européennes et des cultures occidentales. Arras: Artois Presses Université, 2007.

POLLOCK, Frederick; MAITLAND, Frederic William. The History of English Law before the Time of Edward I. Cambridge: Cambridge University Press; Boston: Little, Brown, \& Company, Vol. I, 1895; Vol. II, 1898.

RIBÉMONT, Bernard (Dir.). Crimes et châtiments dans la chanson de geste. Paris: Klincksieck, 2008.

RIBÉMONT, Bernard (Dir.). La faute dans l'épopée médiévale. Ambigüité du jugement. Rennes : Presses Universitaires de Rennes, 2012.

RIQUER, M. de. Los cantares de gesta franceses, sus problemas, su relación con España. Madrid: Gredos, 1952.

RYCHNER, Jean. La chanson de geste: essai sur l'art épique des jongleurs. Genève; Lille: Droz; Girad, 1955.

SARDINHA, Carlos. Alta-traição e lesa-majestade. Germanismo e romanismo na história do direito visigótico primitivo. Lisboa: Universidade Católica, 2011.

SASSIER, Yves. Hugues Capet. Paris: Fayard, 1987.

Louis VII. Paris: Fayard, 1991.

SIVÉRY, Gérard. Louis VIII le Lion. Paris : Fayard, 1995.

Philippe III Le Hardi. Paris : Fayard, 2003.

Saint Louis et son siècle. Paris : Tallandier, 1983, p. 374-397.

SPIJKER, Irene. Le roi Yon: homme pitoyable ou traître félon ? In: ACTES DU XIe CONGRÈS INTERNATIONAL DE LA SOCIÉTÉ RONCESVALS, Barcelona, 22-27 aôut 1988. Memorias de la real academia de buenas letras de Barcelona, vol. 21-22, 1990, Tome II, p. 231-240.

STRANGES, John A. The Character and the Trial of Ganelon. A New Appraisal. Romania, T-96, 1975, p. 333-367.

SUARD, François. La chanson de geste. Paris: PUF, 1993.

Guide de la chanson de geste et de sa postérité littéraire (XIe-XVe siècle). Paris: Honoré Champion, 2011.

SUBRENAT, Jean. Étude sur Gaydon, chanson de geste du XIIIe. Siècle. Aix-enProvence: Presses Universitaires de Provence, 1974. 
THEIS, Laurent. Robert le Pieux. Le roi de l'na mil. Paris : Perrin, 2008.

THIREAU, Jean-Louis. Introduction historique au droit. Paris: Flammarion, 2e. édition, 2003.

VAN WAARD, R. Le Couronnement de Louis et le principe de l'hérédité de la couronne. Neophilologus, Vol. 30, 1946, p. 52-58.

VERDON, Jean. Intrigues, complots et trahisons au Moyen Âge. Paris : Perrin, 2012.

VICTORIO, Juan (direction). L'Épopée. Turnhout-Belgium: Brepols, 1988.

ZUMTHOR, Paul. Charles le Chauve. Paris : Club Français du Livre, 1957. 


\begin{abstract}
APÊNDICES
Das cinco Canções de Gesta utilizadas neste trabalho, somente a Chanson de Roland conheceu uma difusão grande o suficiente para ser conhecida por um público maior na atualidade. Os outros poemas estudados são pouco conhecidos mesmo entre os estudiosos do medievo no Brasil.

Por esse motivo consideramos conveniente apresentar um resumo dos poemas Girart de Vienne, Renaut de Montauban, Gaydon e Jehan de Lançon. Isso permite inclusive ao leitor desta pesquisa ter ao menos uma noção do conteúdo de cada Canção e, talvez, o entendimento da escolha feita nesta Tese por essas fontes.

Quem desejar obter ao menos um texto completo, caso se interesse por algum dos poemas, pode conseguir isso na Internet, através do portal Gallica, site mantido pela Bibliothèque Nationale de France. Ali estão disponíveis o Girart de Vienne (edição de Frederic G. YEANDLE, 1930), o Renaut de Montauban (manuscrito La Valière) e o Gaydon.

Também incluímos dois mapas abrangendo os territórios que compunham o reino da França medieval. O primeiro deles mostra ainda o império de Carlos Magno quando da partilha de Verdun (843), enquanto o outro apresenta os territórios sobre os quais a monarquia capetíngia podia exigir obediência ou a fidelidade de seus senhores. Através deles é possível localizar algumas das cidades e regiões citadas no decorrer de nosso trabalho.
\end{abstract}




\section{APÊNDICE I \\ Resumo da Chanson de Roland (c. 1060-1100)}

Carlos Magno está há sete anos na Espanha e já conquistou quase todo o território, faltando apenas a tomada de Saragoça. O rei desta cidade, Marsílio, convoca seus vassalos e pede conselho de como enfrentar os cristãos. Blancandrino orienta seu senhor a mentir ao imperador dizendo que ia submeter-se, oferecer um tributo e reféns, para que as hostes francas voltassem para suas terras e esperassem, inutilmente, pela ida do chefe pagão à Aix-la-Chapelle onde seria batizado.

Aceita a proposta, Marsílio manda dez pagãos como embaixadores à Carlos Magno. Quando estes encontram o imperador cristão, na cidade de Cordres, que acabava de ser tomada, dizem o conteúdo de sua oferta de paz. Carlos desconfia, mas irá pedir conselho aos seus barões. Os pagãos são alojados até o dia seguinte. Logo cedo são reunidos os barões franceses ${ }^{373}$ para decidir pela paz ou pela continuidade da guerra. Doze nomes são citados, o décimo segundo deles, Ganelon, é imediatamente identificado como traidor.

Carlos expõe a oferta pagã. Rolando, sobrinho do imperador, rejeita a proposta, lembra que os pagãos já mentiram uma vez e os mensageiros Basan e Basílio pagaram com a vida por terem os cristãos acreditado em seus inimigos. Ganelon, padrasto de Rolando, desqualifica a opinião deste, dizendo que o jovem não se importa com a vida dos membros da hoste. Naimes acompanha Ganelon na aceitação da paz, pois seria pecado continuar a guerra quando o adversário se reconhecia derrotado.

O imperador pede que um barão se ofereça como embaixador à Marsílio. Naimes, Rolando, Olivier e Turpin se oferecem um de cada vez, mas Carlos veta o envio deles. Diante do silêncio geral, Rolando propõe o nome de Ganelon, que é prontamente aceito pelo resto do conselho. Furioso com o enteado, Ganelon faz ameaças, mas tem como resposta uma risada de Rolando. Ganelon desafia o sobrinho do imperador e os doze pares de França, mas vê-se obrigado a partir para cumprir as ordens de seu senhor. Ganelon vai sozinho à Saragoça, recusando que seus familiares o acompanhem. Durante a viagem Blancandrino entra em acordo com Ganelon para destruir Rolando.

\footnotetext{
${ }^{373}$ Nas Canções de Gesta os designativos Franc e Franceis são empregados como sinônimos para designar os principais guerreiros cristãos.
} 
Em Saragoça, diante de toda a assembleia pagã reunida em frente ao seu rei, Ganelon transmite a mensagem de Carlos. Mostra bravura diante das ameaças de Marsílio e do filho deste, mas logo Blancandrino diz que o mensageiro ajudará os sarracenos a derrotar os franceses. Uma conversa privada é tida entre o rei Marsílio, seus conselheiros mais próximos e Ganelon, em um vergel. Instado por Marsílio, Ganelon diz que a força de Carlos Magno está em sua vanguarda formada pelos doze pares de França e por vinte mil guerreiros de elite. Destruída esta força, o imperador cristão não ameaçaria mais a Espanha. Também orienta como deveria dar-se a batalha contra os franceses. A traição é jurada e os pagãos oferecem riquezas a Ganelon por sua ajuda.

De volta à hoste franca, Ganelon afirma serem sinceras as propostas de Marsílio e o exército cristão prepara-se para retornar à França. Carlos tem sonhos premonitórios da traição durante a noite. De manhã o imperador pede para escolherem quem cuidaria da retaguarda. Ganelon imediatamente indica Rolando. Este aceita a incumbência, apesar dos temores de seu tio, e recusa o apoio de uma força extra, oferecida pelo rei.

O exército franco avança para suas terras, enquanto as tropas pagãs se reúnem e se preparam para a batalha. O sobrinho de Marsílio pede a este o privilégio de começar o combate e escolhe alguns pagãos importantes para se medir aos doze pares de França. Uma força inicial de cem mil pagãos se apresenta à retaguarda franca. Olivier vê o avanço dos inimigos e pede a Rolando que soe sua trompa para que o resto da hoste cristã volte para enfrentar os pagãos. Rolando se recusa, pois acredita que isso iria desonrá-lo. Os cristãos se preparam para a luta e avançam contra os sarracenos.

$\mathrm{Na}$ primeira batalha os franceses logo abatem os doze pares pagãos e aniquilam a força atacante. Os doze pares de França, Rolando em especial, fazem prodígios. Mas logo aparece o grande exército de Marsílio, com trezentos mil homens. Os franceses continuam a combater, mas são aos poucos reduzidos a apenas sessenta cavaleiros. Rolando, então, diz a Olivier que soará sua trompa para avisar a hoste francesa. Desta vez Olivier é contra. Turpin intervém e o sobrinho do imperador sopra sua trompa com tanta força que provocará sua futura morte, pois o seu esforço ocasionara feridas internas em seu corpo. $\mathrm{O}$ imperador ouve o chamado de sua retaguarda. Ganelon tenta evitar o retorno da hoste dizendo tratar-se de fanfarronada de Rolando. Naimes intervém, diz estar havendo luta e que Ganelon traíra a mesnada do rei. O exército cristão retorna, mas não evitará o massacre de sua retaguarda.

Os últimos cristãos são mortos em combate, inclusive Olivier. Rolando consegue cortar a mão de Marsílio e este foge. O sobrinho do rei e Turpin enfrentam o último ataque 
pagão. Um novo toque da trompa de Rolando tem como resposta os clarins e trombetas da hoste cristã. Os sarracenos fogem depois de haverem matado a montaria de Rolando. Este cuida do arcebispo e, depois, vai recolher os corpos dos pares mortos. Assiste a morte de Turpin e adianta-se em direção à Espanha para mostrar que terminara sua vida como conquistador. Sabendo que a morte se aproxima tenta, inutilmente, destruir sua espada Durandal e, por fim, Rolando faz suas últimas orações e os anjos levam sua alma ao Paraíso.

Carlos chega ao campo de batalha e não encontra nenhum sobrevivente. Inicia-se a perseguição aos pagãos e à pedido do imperador, Deus detém a marcha do Sol para que houvesse luz, permitindo aos cristãos alcançar os inimigos. Perto do rio Ebro dá-se o combate final. Os sarracenos que não são mortos pelas armas francas perecem afogados quando tentavam atravessar o rio a nado. Finda a luta, a hoste franca passa a noite naquele local, com os guerreiros dormindo armados. Novos sonhos premonitórios dominam ao imperador.

Marsílio chega a Saragoça e os pagãos da cidade entram em pânico. Os ídolos dos deuses pagãos são agredidos por não terem ajudado o rei em sua batalha. É lembrado que, no primeiro ano de invasão cristã, Marsílio pedira ajuda a Baligante, emir de Alexandria. Este demorara em reunir suas tropas, mas agora estava a caminho da Espanha. Entrando pelo rio Ebro, a nova hoste pagã chega perto de Saragoça. Baligante manda dois mesageiros para chamar Marsílio à sua presença. Logo que chegam à cidade, os mensageiros ficam sabendo do desastre sarraceno e da presença próxima dos cristãos. Retornam e reportam tudo a Baligante que desembarca suas tropas e inicia a marcha contra os franceses. O emir ainda mantém outro diálogo com Marsílio, mas logo se reúne ao seu exército.

Enquanto isto, a hoste franca retorna a Roncesvales. Carlos encontra o corpo de Rolando e lamenta-se pela sua perda. Os cristãos mortos são sepultados; Rolando, Olivier e Turpin têm os corpos preparados para serem levados à França. Aparece a vanguarda pagã; mensageiros chamam Carlos para o combate. O imperador ordena aos cristãos para se prepararem e dez esquadrões de cavaleiros são formandos para enfrentar os pagãos.

Baligante vê o avanço francês e organiza os seus trinta esquadrões, que superam em número aos cristãos. Os exércitos se chocam e o combate dura o dia todo. Apesar de sua superioridade em homens, os sarracenos são batidos aos poucos. O filho e o irmão do emir são mortos por Naimes e Carlos. Um último ataque pagão falha na tentativa de reverter a batalha. Baligante e Carlos se encontram no meio do campo e a luta que travam a cavalo e 
à pé só poderia terminar com a morte de um deles, pois ambos rejeitam qualquer proposta de sujeição. O emir consegue ferir o imperador, mas este, amparado por anjos, revida e mata Baligante. Os sarracenos são derrotados e fogem. Os cristãos avançam até Saragoça, tomam a cidade, destroem os ídolos e batizam à força os habitantes. No dia seguinte Carlos inicia o retorno à França, levando cativa a rainha Bramimonda.

Em terras cristãs são sepultados Rolando, Olivier e Turpin. Chegando a Aix-laChapelle, Carlos dá notícia à Auda da morte de seu noivo Rolando. A jovem se recusa a viver sem ele e morre diante do imperador, sendo sepultada em uma abadia. O imperador convoca os barões do reino para que Ganelon seja julgado por sua traição.

Quando do julgamento, Carlos inicia acusando o barão de prejudica-lo com a perda de vinte mil franceses e de Rolando, a quem traíra por dinheiro. Ganelon concorda ter buscado a destruição de Rolando, mas nega ter traído. Segundo ele o enteado o prejudicara, tinha havido um desafio público e o caso era apenas uma vingança. Após sua defesa Ganelon busca a proteção de seus parentes, em especial do temível Pinabel.

Os barões, por temor a Pinabel, dizem ao imperador para perdoar Ganelon. Carlos se sente desamparado, mas o jovem Thierry de Anjou toma a causa do imperador e afirma ter havido traição a Rolando e perjúrio ao imperador por parte de Ganelon. Pinabel rebate dizendo que tal acusação é falsa. Ambos os cavaleiros iriam se enfrentar em duelo. Preparados, os combatentes iniciam a luta montados, mas logo estão duelando à pé. Cada um deles recusa as ofertas do outro para encerrar a luta. Pinabel fere Thierry, mas este revida e mata o oponente. Findo o combate, os trinta parentes que se ofereceram como garantia de Ganelon são enforcados. O traidor é esquartejado com cada membro atado a um cavalo.

Carlos consegue que Bramimonda aceite o batismo cristão. Deitado, durante a noite, o imperador recebe a visita de um anjo que o incita a conduzir novamente suas tropas contra os pagãos. Carlos lamenta seu destino e o poema termina. 


\section{APÊNDICE II}

\section{Resumo da Canção Girart de Vienne (c. 1180-1184)}

O poeta inicia classificando as três gestas épicas francesas: a do rei (ou dos reis) da França; a de Doon de Mayence, linhagem da qual saem os traidores épicos; e a de Garin de Monglane, caracterizada pela bravura e lealdade. O poema que será narrado é a desta última gesta, ao qual o poeta informa que apresentará o início da história de Girart de Vienne e que é desconhecido dos outros poetas/jograis.

Garin, sua esposa e seus filhos Hernaut, Milon, Renier e Girart estão passando necessidades devido a uma invasão pagã às suas terras em Monglane. Os jovens remediam a situação atacando e pilhando um grupo de mercadores sarracenos. Girart, apesar da pouca idade, destacou-se na luta. Depois os filhos partem para tentar fortuna. Hernaut logo se torna senhor de Biaulande e Milon conquista a Apúlia. Renier e Girart vão para a corte de Carlos Magno. Ao passarem por Vienne ${ }^{374}$ o caçula almeja um dia ser senhor desta cidade. Em Cluny são honrados pelo abade.

Mal recebidos na corte régia devido à sua pobreza, os jovens envolvem-se na morte de um senescal e do porteiro do rei. Carlos deseja puni-los, mas os rapazes se justificam pela má acolhida. Os outros barões os apoiam e o imperador arma Renier cavaleiro e faz de Girart seu escudeiro. Renier logo mostra suas qualidades bélicas livrando o domínio real de bandoleiros (larrons). Em uma festa de pentecostes chegam mensageiros à corte, mandados por Hernaut e Milon, e anunciam os ganhos dos irmãos mais velhos. Irritado, Renier exige um feudo ou procuraria outro senhor; Carlos reage furioso e Girart tenta acalmar o irmão e o rei. Pela intervenção dos barões o rei cede a Renier a cidade e a região de Genebra.

Girart permanece na corte e é estimado por todos. Durante uma caçada Carlos recebe a notícia de que a viúva do duque de Borgonha vinha à corte pedir novo marido. $\mathrm{O}$ imperador arma Girart cavaleiro e promete dar-lhe a duquesa como esposa. Mas ao ver a mulher, Carlos a deseja para si. A duquesa tenta fazer com que Girart a despose

\footnotetext{
${ }^{374}$ Embora possa ser traduzida por Viena preferimos manter o nome francês Vienne para essa cidade localizada às margens do rio Ródano, procurando evitar qualquer associação com a mais conhecida Viena, capital da Áustria e localizada às margens do rio Danúbio.
} 
rapidamente, mas o jovem rejeita essa iniciativa. Irritada ela aceita casar com o imperador, apesar da reclamação de Girart. Para compensar a falta de palavra, o rei oferece Vienne ao jovem e o rapaz, agradecido, vai beijar o pé de seu senhor que já está deitado com a nova rainha. Esta, aproveitando a falta de luz, oferece seu pé para ser beijado, o que motivará a futura guerra. Girart vai para Vienne.

Certo dia chega a Vienne o jovem Aymeri, filho de Hernaut de Biaulande, e permanece algum tempo com Girart e, depois, vai a Paris para servir o rei. Aymeri mostra suas qualidades derrotando um grupo de bandoleiros e é logo aceito por Carlos, que estava em Saint Denis. Enquanto este retorna a Paris, o jovem permanece com a rainha e esta se vangloria de ter feito Girart beijar seu pé. Ofendido, Aymeri tenta matar a mulher e é obrigado a fugir para Vienne. Quando Girart é informado da ofensa, reúne o pai e os irmãos para discutir o que fazer. Garin prefere que o rei se diga inocente da ofensa e entregue a rainha para ser punida. Chegam mensageiros de Carlos exigindo o comparecimento de Renier e de Girart à corte, acusados de não cumprirem seus deveres vassálicos.

No encontro em Chalon-sur-Saône o clã de Girart reclama a punição da rainha. Carlos responde exigindo o cumprimento dos deveres por Renier e Girart. A altercação desemboca em confronto físico e a linhagem de Garin é obrigada a fugir perseguida pelos imperiais. Graças a reforços de Vienne conseguem repelir o rei, mas este jura cercar Vienne. De volta à cidade do Ródano, a linhagem discute a reação contra o rei. Descartada a proposta de derrubar Carlos, eles partem para a conquista da Borgonha, atacando a cidade de Mâcon. O imperador, ao tomar conhecimento do ataque, reúne suas tropas e parte para o cerco de Vienne.

O assédio da cidade dura sete anos. Rolando propõe levantar um manequim para que os jovens da hoste treinem seus golpes de lança. Carlos teme que isso atraia os guerreiros de Vienne, mas é convencido a aceitar. Olivier, filho de Renier de Genebra, vem incógnito à hoste e derruba o manequim. Logo se desenrola o combate entre as forças de Carlos e de Girart. Rolando encontra a irmã de Olivier, Auda, que saíra da cidade para ver a luta, e tenta levá-la consigo, mas é impedido pelo irmão da jovem. Este ainda consegue capturar Lamberto de Berry, afilhado do rei. Renunciando a um resgate, Girart pede a Lamberto para proteger Olivier que vai como mensageiro propor a paz a Carlos Magno.

Na entrevista com o imperador Olivier afirma que Girart seguirá Carlos e o servirá lealmente. O rei responde dizendo querer vingar-se de Girart. Olivier afirma que seus 
ancestrais não deviam fidelidade a Carlos por Vienne e ameaça convocar outros parentes para devastar a França. Rolando acusa Girart de traição e o sobrinho deste desafia o sobrinho do rei, que aceita o duelo no qual se decidiria a sorte da guerra. Todavia, o encontro descamba para o ataque contra Olivier que foge protegido por Lamberto e é socorrido por Girart. Na batalha que se segue Girart golpeia o imperador e depois se humilha diante deste, pedindo a paz. Os cavaleiros de Vienne conseguem a custo voltar à cidade. Carlos ordena o ataque contra as muralhas, mas não obtém resultados. Rolando e Auda se enamoram.

Numa ilha do Ródano Olivier e Rolando se encontram para duelar. O combate dura o dia todo e em cada um dos jovens cresce a admiração pelo adversário, enquanto em Vienne e na hoste imperial há lamentos quanto a possibilidade dos dois rapazes virem a morrer. Auda faz orações para que os dois combatentes sejam protegidos. Deus intervém levantando uma nuvem na ilha e mandando um anjo encerrar o combate e ordenando aos guerreiros ir combater os pagãos na Espanha. Rolando e Olivier troca o beijo da paz, juram amizade e cada um deles volta a seu campo.

Olivier é bem recebido em Vienne; Rolando é censurado por Carlos que deseja continuar o cerco. Seu sobrinho se nega a continuar a luta. Olivier incentiva Girart a pedir a paz ao imperador, mas um ataque lançado por Aymeri contra a hoste real põe tudo a perder. Enquanto Girart censura o sobrinho atrevido, um espião informa que o rei irá caçar no dia seguinte na floresta de Clermont.

Girart reúne seus homens e vai emboscar o imperador. Carlos se separa de seus barões e homens ao perseguir um javali. Acaba sozinho diante de Girart. Este rejeita a proposta de Aymeri de matar o monarca e, humilhando-se, pede para ser perdoado pelo rei. Carlos concorda em perdoá-lo e à sua linhagem. Esta, inclusive o recalcitrante Aymeri, juram fidelidade ao rei. Todos retornam a Vienne, onde Carlos é bem tratado. A captura do rei, segundo o poeta, também era algo desconhecido de outros poetas.

No dia seguinte, Carlos e Girart, junto com o resto da parentela deste, dirigem-se para a hoste franca. Todos comemoram a paz. O imperador restitui os feudos de Girart. A união de Rolando com Auda é jurada, mas chegam mensageiros informando de uma invasão sarracena à Gasconha. São dadas ordens para que as tropas cristãs se preparem para invadir a Espanha. Girart e Hernaut deverão administrar a França na ausência do imperador. 


\section{APÊNDICE III \\ Resumo da Canção de Renaut de Montauban (início do século XIII)}

O poema Renaut de Montauban se inicia com Carlos Magno reunido sua corte num Pentecostes e reclamando da ausência de alguns vassalos na expedição levada a efeito contra os saxões, na qual morrera seu sobrinho Balduíno. Sob o conselho de Naimes, Carlos envia uma embaixada, ao principal faltoso, Bueves de Aygremont, escolhendo seu filho Lotário para comanda-la ${ }^{375}$. Este, avisado da chegada dos mensageiros, tem intenções belicosas contra os enviados e contra o próprio rei. Em Aygremont, Lotário se encontra com Bueves e a conversa logo desemboca em provocações e o senhor da cidade ordena a prisão dos franceses; estes se defendem, mas durante o combate, Bueves mata Lotário e os sobreviventes da embaixada levam seu corpo para Paris.

Enquanto isso, Carlos arma cavaleiros os filhos do irmão de Bueves, Aymon de Dordonne. Dos quatro jovens destaca-se Reinaldo, que é armado pelo imperador e presenteado com o cavalo encantado Bayart. O novo cavaleiro e seus irmãos, Aalard, Guiscardo e Ricardinho, prometem fidelidade e serviço ao rei. A fatídica embaixada se aproxima de Paris e Carlos vai ao seu encontro, chorando a perda de Lotário. Aymon e sua mesnada, temendo represálias pelo assassinato, abandonam a corte rapidamente e se refugiam em sua fortaleza. O filho do rei é sepultado.

O imperador reúne sua hoste para punir Bueves, mas é orientado a dar uma chance ao culpado, perdoando-o caso ele lhe viesse prestar homenagem expiatória ${ }^{376}$. Carlos envia Ogier o Dinamarquês como mensageiro, propondo um salvo conduto ao assassino de Lotário. Bueves aceita a proposta e parte com uma pequena escolta. O imperador, ainda inconformado com o assassinato e orientado por um clã de malfeitores instalado em sua

\footnotetext{
${ }^{375}$ Utilizamos em nosso estudo desta Canção o manuscrito Douce. No manuscrito La Vallière o início do poema é diferente. Uma primeira embaixada é enviada a Aygremont, sob o comando de Enguerrand, convocando Beuves - é esta a grafia usada nesta versão do poema para o nome do barão - a se justificar pelo apoio dado à revolta de seu irmão Doon de Nanteuil. O mensageiro é morto e seu corpo conduzido até Carlos; só então Lotário é escolhido, por Naimes da Baviera, para uma nova tentativa de obter a submissão do barão faltoso.

${ }^{376} \mathrm{O}$ manuscrito La Vallière se afasta novamente do Douce, fazendo a hoste de Beuves, Geraldo e Doon avançarem sobre as terras imperiais e cercarem Troyes. Eles são derrotados por Carlos Magno e obrigados a pedir a paz. É após este acordo que o imperador manda emboscar Beuves. Não são dados muitos detalhes da tentativa de vingança dos irmãos do morto. Apesar de atingirem Paris, eles entraram em entendimento com Carlos e providenciaram a construção de vários edifícios religiosos, como penitência.
} 
corte - a linhagem de Ganelon - ordena uma emboscada contra o seu inimigo. A armadilha funciona e Bueves é morto. O filho deste, Maugis, jura vingança e pede socorro aos tios Girart de Roussillon e Doon de Nanteuil. Reunido um forte exército, eles invadem as terras imperiais e cercam Troyes. Carlos é informado e leva sua hoste contra os rebeldes. No violento combate travado, a linhagem revoltada é obrigada a pedir a paz ao rei e este aceita o pedido, em troca do perdão do assassinato de Bueves. Esse acordo seria comemorado em Paris, com uma grande festa, na qual Aymon e seus filhos compareceram.

No decorrer de uma partida de xadrez Reinaldo é agredido por um sobrinho de Carlos, Bertolai, e quando o imperador lhe nega justiça pela morte de Bueves de Aygremont, o jovem mata o seu agressor. Os quatro filhos de Aymon conseguem fugir da corte, mas seu pai é obrigado a renega-los, expulsando-os de suas terras. Os banidos se instalam na floresta de Ardennes, onde constroem o castelo "bastardo" de Montessor. Quando Carlos descobre o paradeiro dos fugitivos, reúne uma hoste e cerca a fortaleza dos rebeldes. Os jovens resistem às forças imperiais por muito tempo, até o rei aceitar uma proposta baseada na mentira, feita por Hervis de Lausanne. Este se apresenta aos filhos de Aymon como se tivesse abandonado Carlos em favor dos rebeldes. Aceito em Montessor, à noite ele permite a entrada de um destacamento imperial que massacra a maioria dos cavaleiros da fortaleza; Reinaldo consegue derrotar e capturar Hervis, executando-o de forma humilhante. Depois os Aymonidas abandonam Montessor e, embora perseguidos pelas tropas de Carlos Magno, conseguem se esconder na floresta das Ardennes. Mais tarde encontram e travam combate contra o contingente de seu pai, Aymon, sendo obrigados a se internar na selva, onde passam a ter uma vida dura, recorrendo por vezes à rapina das regiões vizinhas. Tornados irreconhecíveis pela sua vida miserável na floresta, os jovens decidem ir ao encontro de sua mãe, em Dordonne. Conseguem encontra-la e, identificados, passam a ser bem tratados. Aymon lamenta sua atitude anterior, de hostilidade em relação aos filhos, mas ainda está obrigado por juramento ao imperador a repudiá-los, entretanto ele permite à sua mulher cuidar dos rapazes e dar-lhes recursos. Os jovens reúnem uma tropa de cavaleiros e, logo, o seu primo Maugis se junta ao grupo, trazendo um tesouro roubado ao rei na cidade de Órleans. Reinaldo e sua companhia seguem para a Gasconha, onde tentariam se estabelecer.

Chegando em Bordeaux, os quatro filhos de Aymon são aceitos como vassalos pelo rei Yon e, breve, vencem os inimigos sarracenos deste. Ganham o direito de construir uma fortaleza, Montauban, que - graças às franquias oferecidas por Yon - atrai muitos comerciantes e artesãos. Pouco depois Reinaldo se casa com Clarice, irmã do rei da 
Gasconha. Carlos Magno, retornando de uma peregrinação a Santiago de Compostela, descobre os jovens cavaleiros e, tendo Yon se negado a entrega-los, retorna a Paris onde propõe mover guerra a Reinaldo. O jovem Rolando aparece na corte e logo demonstra seus dotes militares, ao derrotar os saxões que cercavam Colônia. Sob a orientação de Naimes, Carlos prepara uma corrida de cavalos, onde pretendia conseguir uma montaria digna para o seu sobrinho. Reinaldo, sabendo da corrida, vai participar dela, levando o primo Maugis cujas mágicas disfarçam a este, a Reinaldo e a Bayart. A corrida é vencida pelo Aymonida, que foge levando a coroa real, oferecida como prêmio ao vencedor da prova, e deixando Carlos furioso.

O imperador reúne suas forças; diante das reticências dos vassalos, exige destes o envio de seus filhos ou sobrinhos para a hoste. Entrando na Gasconha, ocupam a fortaleza de Montbendel. Carlos envia um mensageiro a Yon intimando-o a entregar os quatro irmãos. Pressionado por seus conselheiros, o rei gascão concorda em trair seu cunhado e responde afirmativamente à proposta do imperador. Yon parte para Montauban e convence Reinaldo de que conseguira a paz com Carlos, devendo os jovens ir ao seu encontro, em Valcoulours. Reinaldo tem alguma dificuldade para obter o acordo dos irmãos para segui-lo nessa jornada, ignorando estar a caminho de uma emboscada comandada por Fouque de Morillon e Ogier o Dinamarquês. Atacados logo ao chegar, os quatro filhos de Aymon são feridos, mas se defendem vigorosamente. Ogier, como é primo dos jovens, tenta chamar a atenção de Maugis para o local da luta; entretanto o mágico já estava sendo informado por um clérigo de Yon sobre a traição deste e partia para socorrer seus parentes. Os franceses são derrotados; Fouque é morto e Ogier, ao ser chamado de traidor, combate Reinaldo, mas no final o dinamarquês é constrangido a retornar a Carlos para falar da derrota. Acusado de infidelidade por Rolando, Ogier é obrigado a se defender diante da corte, mas o imperador aceita suas desculpas.

Ao saber do fiasco da emboscada de Valcoulours, Yon foge para uma abadia onde se faz monge. Todavia é preso por Rolando e conduzido para ser enforcado diante de Montauban. Reinaldo recebe mensageiros de seu cunhado e decide salvá-lo. O encontro com o sobrinho de Carlos degenera em violento combate. Graças à sorte, Reinaldo consegue libertar Yon, que passa a ser seu prisioneiro. Rolando é vítima de gozações de Ogier, mas logo depois é desafiado pelo mais novo dos Aymonidas, Ricardinho. Este é capturado e levado para o imperador. Ao saber da prisão de seu primo, Maugis se metamorfoseia em peregrino e alcança a hoste real, onde consegue enganar a todos e 
humilhar Carlos. Assim que descobre onde Ricardinho iria ser enforcado, volta para Montauban.

O imperador reúne o conselho visando escolher um responsável pela execução de seu prisioneiro e encontra a resistência de todos os pares da França. Finalmente aparece um voluntário, Ripeu de Ripemont, para conduzir Ricardinho à forca, de onde este é salvo pelos irmãos enquanto seu algoz é morto. Após o resgate, os Aymonidas, incentivados pelo primo, fazem um ataque ao acampamento do rei, onde Maugis é capturado por Olivier e entregue a um Carlos Magno que está desesperado e ameaçando renunciar à coroa em favor de Reinaldo, constrangendo os seus homens. Embora o imperador desejasse a execução imediata do prisioneiro, Naimes o convence a deixar isso para o dia seguinte, pois já era muito tarde. À meia-noite, Maugis usa de seus encantamentos para adormecer a hoste, abrir as cadeias que o prendem e fugir levando consigo as espadas do rei e dos doze pares, bem como a coroa real.

Para reaver esses objetos, um encontro é feito entre o imperador e os rebeldes, onde fica acertado um duelo entre Rolando e Reinaldo. No decorrer da luta uma nuvem desce sobre os combatentes e os impede de combater; Reinaldo convida o sobrinho de Carlos a acompanha-lo até Montauban e Rolando promete fazer o possível para uma reconciliação com seu tio. À noite, Maugis consegue raptar o rei e leva-lo para a fortaleza de seus primos. Após estes prometerem respeitar a vida do prisioneiro, o mágico se retira da cidade e vai ser eremita na Floresta da Serpente. Quando o imperador acorda, fica furioso pela situação na qual se encontra e, apesar dos pedidos de paz dos Aymonidas, de Rolando e de Naimes, afirma desejar primeiro executar Maugis. Diante das recusas de Carlos e não aceitando lhe fazer algum mal, Reinaldo o liberta e, depois de confirmar a partida de seu primo mágico, libera os outros franceses retidos em Montauban.

Começa o cerco da fortaleza, marcado pelas saídas dos defensores em busca de provisões e pelos assaltos infrutíferos dos franceses. Carlos espera vencer os rebeldes pela fome. O plano começa a funcionar, apesar de Aymon de Dordonne, por um tempo, ter suprido seus filhos através de suas catapultas. Após sacrificar seus cavalos, menos Bayart, um velho ensina os Aymonidas como abandonar a cidade, usando um túnel secreto cuja saída dava na Floresta da Serpente. Os assediados partem e conseguem alimentos junto a um eremita, indo depois buscar refúgio na cidade de Tremoigne (Dortmund), na região renana. Carlos toma Montauban vazia e envia espiões procurar os fugitivos; descoberta a localização destes, a hoste real parte para Tremoigne e novos combates e outro cerco começam. Maugis abandona seu eremitério e vai ao encontro dos primos, prometendo 
ajuda-los a conseguir a paz com Carlos Magno. Em um entrevero os Aymonidas capturam Ricardo da Normandia; enquanto isso Maugis sequestra Carlinhos, filho do imperador. Diante da ameaça de ver seu importante vassalo e seu filho enforcados e da disposição dos franceses em abandonar o rei por não concordarem com a guerra contra Reinaldo, Carlos aceita fazer a paz com os rebeldes ${ }^{377}$. Para isso Reinaldo deveria partir em peregrinação ao Santo Sepulcro e Bayart lançado ao Reno, para morrer afogado; entretanto o cavalo encantado escapa do rio e se reúne a Maugis na floresta das Ardennes.

Como um pobre peregrino Reinaldo chega à Palestina, onde reencontra o primo mágico, também em peregrinação. Ambos vão para Jerusalém, cercada pelo exército cristão. Em um primeiro combate, ainda como penitentes e sem as armas dos cavaleiros, os dois heróis espalham o terror entre os sarracenos; após a fuga dos infiéis, os barões cristãos descobrem quem são os peregrinos e se tornam homens lígios de Reinaldo. Em novo combate Jerusalém é conquistada. Reinaldo recusa a coroa que lhe é oferecida e Godofredo de Nazaré, que se distinguira na luta, é feito rei. Os primos se despedem dos cruzados e voltam para a França, onde Maugis retorna ao seu eremitério e Reinaldo vai ao encontro dos irmãos. Fica sabendo da morte de Clarice e se dirige a Paris, para ver Carlos Magno e os seus dois filhos, Yonet e Aymonet ${ }^{378}$.

Na corte, os parentes de Fouque de Morillon procuram vingança pela sua morte às mãos de Reinaldo, em Valcoulours. Os filhos de Fouque, Constâncio e Rohart, acusam o herói de traição e os filhos de Reinaldo dizem que combaterão pela inocência de seu pai. No duelo, apesar da tentativa de intervenção da linhagem dos traidores, os filhos de Reinaldo saem vitoriosos. Carlos quer fazer do Aymonida seu senescal, mas este se desculpa dizendo ter assuntos urgentes a tratar em Montauban.

Voltando à sua fortaleza, Reinaldo distribui seus bens e se retira para a floresta, onde vive como eremita algum tempo. Sabendo da construção da igreja de Colônia, para lá se dirige e se oferece como servente na obra: procura trabalhar bastante para purgar seus pecados, recebendo o mínimo de pagamento. Isto gera a inveja dos demais trabalhadores, temerosos de ver o próprio salário diminuído. Eles assassinam Reinaldo e jogam seu corpo no Reno. Todavia o cadáver é milagrosamente resgatado e os assassinos exilados. Quando

\footnotetext{
377 Aqui temos outra discordância do manuscrito Douce com o La Vallière: neste apenas Ricardo da Normandia é feito prisioneiro e a solidariedade dos doze pares possibilita a paz entre os Aymonidas e o imperador. Em certo momento quase toda a hoste francesa se retira por discordar de Carlos, permanecendo no cerco a Tremoigne apenas a linhagem de Ganelon.

${ }^{378}$ No La Vallière o poeta dedica alguns versos nos quais fala do retiro e da morte de Maugis, em seu refúgio, após sete anos de penitência. Também amplia o episódio no qual Reinaldo descobre sobre o falecimento de sua mulher, fato que os irmãos tentaram, a princípio, esconder.
} 
ia fazer-se o seu enterro, o carro que conduzia o herói andou, sem condutor, em direção a Tremoigne e, lá chegando, os sinos da cidade começaram a tocar sozinhos. O bispo local reconhece Reinaldo e consola os irmãos deste. O herói é enterrado na catedral e, tornado santo, começa a fazer muitos milagres. 


\section{APÊNDICE IV \\ Resumo da Canção de Gaydon (c. 1230-1234)}

Carlos Magno está se retirando da Espanha, após o desastre de Roncesvales e a morte de Rolando. Ganelon já foi punido e os parentes do traidor pensam em vingar-se do imperador e do vencedor de Pinabel, o cavaleiro Thierry de Anjou, também conhecido como Gaydon. O apelido deste decorreu do fato de um pássaro ter pousado em seu elmo logo após a vitória no duelo judicial.

Thibaut de Aspremont manifesta aos seus parentes o desejo de vingar a morte do irmão Ganelon. Alori cita também Naimes da Baviera e Ogier o Dinamarquês como inimigos da linhagem. Thibaut lembra os tempos em que fora monge em Saint-Denis e aprendera a fazer remédios e venenos. Leva os primos para uma tenda e prepara algumas frutas embebidas em um veneno que ele guardara, enviando-as como um presente de Gaydon à Carlos Magno. O imperador fica feliz com a oferta, mas um jovem cavaleiro que experimenta a fruta cai morto. Carlos acredita em uma traição de Gaydon. Este, sem nada saber do ocorrido, comparece à tenda do rei pela manhã. O herói nega o crime, mas Thibaut afirma que Gaydon era culpado e provaria isso em duelo.

Irritado com a conduta de Carlos, Thierry manda seus sobrinhos Ferraut e Amanfroi levar as suas bagagens e riquezas para a cidade de Angers. Os Ganelidas descobrem o plano e preparam uma emboscada ao comboio.

No dia seguinte teria lugar o combate no qual Gaydon vence Thibaut, decapitandoo. O corpo do traidor permanece insepulto amarrado pelas axilas em um patíbulo. O herói vai se recuperar de seus ferimentos. Enquanto isso os seus sobrinhos são atacados pelos Ganelidas que, em número superior, começam a sobrepujar os Angevinos. Os traidores invadem a fazenda de um vavassalo expulso de Angers, Gautier, e este, junto com os seis filhos, entra no combate ao lado dos sobrinhos de Gaydon. No final, Gautier ficará apenas com dois filhos vivos. Um mensageiro consegue avisar Thierry da emboscada e este corre em socorro de seus parentes. Os Ganelidas são derrotados. Os Angevinos chegam a sua cidade-fortaleza.

Gaydon tenciona desafiar Carlos e mover-lhe guerra. É contido pelo velho e sábio conde Rioul, que orienta a exigir que o clã de traidores seja expulso do reino ou entregue 
ao herói para ser punido. Ferraut é enviado como mensageiro à Paris. No caminho encontra um mensageiro do imperador a quem combate inicialmente e, depois, torna-se amigo. Em Paris, Ferraut é impedido pelo porteiro de cumprir sua missão junto a Carlos; o porteiro é morto. O sobrinho de Gaydon, diante da corte transmite a mensagem de Gaydon e desafia o imperador, retirando-se logo em seguida. Ao saber da morte do porteiro Carlos manda perseguir o mensageiro, mas este escapa. Os Ganelidas tentam emboscar Ferraut na sua volta para Angers e fracassam. Durante o retorno, Ferraut se apodera de um cavalo que ia ser oferecido como tributo de Toulouse ao imperador e, depois, mais quatro cavalos carregados de dinheiro que os parentes de Ganelon iam presentear ao rei.

O sobrinho de Gaydon é acolhido traiçoeiramente por Hertaut, um Ganelida, que oferece hospitalidade para poder mata-lo. O plano é denunciado pela esposa do traidor, pois ela é parenta dos angevinos, e o cavaleiro recebe a ajuda de Savari, o filho dessa mulher, que vai pedir socorro a Gaydon, enquanto Ferraut sustenta sozinho o assédio dos traidores. Thierry chega a tempo de evitar o enforcamento do sobrinho e destrói o castelo ganelida.

Carlos fica sabendo dos atos de Ferraut pelas reclamações do clã de traidores. O imperador reúne uma hoste e marcha contra Angers. Ao chegarem ao destino ocorre um primeiro combate. Lutando por Gaydon estão os filhos de vários vassalos da hoste real, incluindo Bertrand e Richier, os filhos de Naimes. No final do enfrentamento Ferraut é capturado pelos imperiais, mas os Angevinos levam Ogier cativo para sua fortaleza. Há a possibilidade de uma troca de prisioneiros, o que não é desejado pela linhagem de Ganelon. Gui de Autefoille acusa o sobrinho de Gaydon e o desafia para um duelo judicial e Ferraut aceita. Caso este viesse a ser morto Thierry poderia vingar-se executando Ogier e, com isto, a paz seria impossível. Savari vem de Angers propor a troca de prisioneiros e sabe do ordálio que haveria no dia seguinte; retorna e avisa Gaydon. Os Ganelidas escondem cavaleiros que intervirão caso Gui não consiga sustentar a luta. Os Angevinos, temendo por Ferraut, também vêm instalar-se, às escondidas, perto do campo do duelo. No dia seguinte o duelo é travado, apesar de duro o combate Ferraut caminha para a vitória, mas o clã traidor intervém e só não matam o herói devido à ação imediata dos homens de Gaydon. Nova batalha geral; os Angevinos conseguem retornar à sua cidade. Com o sobrinho em segurança, Gaydon libera Ogier. Ferraut e Amanfroi o escoltam até o campo imperial e no retorno socorrem o vavassalo Gautier, que fora capturado pelos Ganelidas. A sorte se volta contra os heróis e estes quase são enforcados pelos traidores; a intervenção 
dos homens de Claresme, rainha da Gasconha, salva os cavaleiros. A jovem viera a Carlos pedir um marido, mas a sua intenção real era casar-se com Gaydon.

Os sobrinhos e Gautier falam a Thierry de Claresme. Esta tem o desprazer de ser oferecida a Gui de Autefoille pelo imperador. A jovem envia um pajem à Gaydon pedindo para este vir visitá-la à noite. O barão aceita após ser censurado por Gautier pelo seu desinteresse por mulheres. Gaydon vai à tenda de Claresme acompanhado apenas do vavassalo. Um serviçal da rainha avisa os Ganelidas da presença dos Angevinos e um grupo de cavaleiros vai tentar prendê-los. Gaydon acredita que Claresme o traíra, mas ela consegue provar sua inocência e foge com o herói para Angers. São alcançados pelos traidores e obrigados a se defenderem. Ferraut vê o tio em dificuldades e parte em seu socorro. Novo combate e os Ganelidas são obrigados a recuar. Os Angevinos também abandonam o campo diante da chegada das tropas de Carlos Magno. O vavassalo Gautier encontra Claresme, que havia se perdido, e a entrega a Gaydon, não sem antes de fazer-lhe algumas provocações.

Carlos, irritado por não derrotar o rebelde, propõe ir pessoalmente a Angers, disfarçado de peregrino, para conhecer a força de seu inimigo. Naimes da Baviera o acompanha. Aceitos na cidade, eles logo percebem o poderio de Gaydon e lamentam a situação perigosa na qual se meteram. Conduzidos ao jantar do duque, os filhos de Naimes logo desconfiam dos dois peregrinos e vão desmascará-los. Há uma briga entre o rei e seu acompanhante com os jovens e os pelos do bigode de Carlos são arrancados por um dos rapazes. Levados à presença de Gaydon, os falsos peregrinos são bem tratados e o imperador perdoa o jovem que o ofendera. Concorda-se em fazer a paz.

No dia seguinte Thierry conduz seu senhor à hoste. Os Ganelidas fingem alegria, mas planejam uma nova traição para matar o imperador e o barão. Aconselhado por Rioul, Gaydon volta para Angers ao anoitecer. O clã dos traidores consegue embriagar Carlos e, durante a noite, acordam-no dizendo que os Angevinos haviam atacado e desbaratado a hoste franca. Com isso partem do acampamento levando o rei prisioneiro. Gaydon, avisado por um anjo da traição dos Ganelidas, parte em socorro do imperador. Alcançamno e colocam os traidores em fuga. Logo chegam outros membros do exército real, inclusive Naimes e Ogier, que os Ganelidas disseram terem sido mortos.

A paz é selada entre Carlos e Thierry. Este desposa Claresme e o rei volta a Paris. A felicidade de Gaydon não dura muito: sua esposa falece pouco tempo depois e ele acaba seus dias como eremita. Quanto a Carlos, os traidores conseguem voltar à corte e continuam com suas maldades. 


\section{APÊNDICE V \\ Resumo da Canção de Jehan de Lançon (c. metade do século XIII)}

Carlos Magno tem uma corte em Paris na qual estão seus mais valorosos cavaleiros $^{379}$. O imperador reclama da independência de Jehan de Lançon, que não é seu vassalo, e afirma que irá reduzi-lo à obediência pela guerra, se necessário. Seu sobrinho Rolando critica essa postura do rei, declarando que este só pensa em fazer guerras. Irritado, Carlos tenta agredir Rolando, mas é impedido pelos demais barões. O imperador então ordena ao sobrinho para ir como mensageiro a Lançon, intimar Jehan a vir servi-lo na corte. Um a um, os doze pares da França intervém, tentando fazer seu senhor voltar atrás em sua decisão. Em vez disso Olivier, Naimes, Ogier, Basin e os outros pares recebem ordens de acompanhar Rolando na perigosa embaixada.

Não podendo recusar a missão, os cavaleiros partem de Paris e seguem para as terras de Jehan. Quando chegam em Lançon ficam maravilhados com a cidade e entram determinados a anunciar sua mensagem. Mas enquanto avançam pelas ruas, são molestados pelo irmão de Jehan, Nivart, que é morto por Rolando. Há um primeiro combate. E o senhor da cidade leva seus homens para destruir os franceses. Estes se abrigam em uma torre e sustentam a luta contra os sitiantes.

Vendo que não poderia vencer os franceses, Jehan aceita os conselhos de Alori e finge estar disposto a honrar os mensageiros e submeter-se a Carlos Magno, para depois matar os doze pares. Estes caem na armadilha e acompanham o traidor até seu palácio onde jantam. Jehan reúne seus homens e fala sobre seu plano de traição. Um de seus vassalos, Isoré, censura o senhor por recorrer a algo que seria censurado em todas as cortes. Alori dá outra ideia: assassinar os franceses no dia seguinte, depois de convida-los para uma caçada na floresta. A proposta é aceita por Jehan. Isoré não se conforma e resolve avisar os doze pares da traição. Em troca pede a intercessão deles para que o imperador lhe perdoe faltas passadas. Rolando e os outros concordam. No dia seguinte Jehan convida os mensageiros para caçar. Alori já está emboscado na floresta. Isoré volta

\footnotetext{
${ }^{379}$ Neste resumo preferimos seguir a ordem narrativa que teria existido no poema original de Jehan de Lançon, uma vez que na edição utilizada neste trabalho o manuscrito mais antigo, do século XIII, está mutilado de toda a sua parte inicial. A parte faltante foi suprida com outro manuscrito, muito alterado, do século XV.
} 
a falar com seu senhor para evitar a traição e é privado de seus feudos. Agora justificado, Isoré reúne alguns cavaleiros fiéis para ajudar os doze pares.

Uma violenta batalha ocorre e os franceses conseguem se salvar abrigando-se em uma torre abandonada, perto de um rio. Isoré é capturado pelos de Lançon, mas os pares conseguem prender Alori. À noite Basin sai da torre e vai ao acampamento de Jehan disfarçado de peregrino para libertar Isoré. Denunciado, ele é preso junto com este companheiro, mas à meia-noite, usando de magia, consegue libertar-se e ao outro prisioneiro, voltando para a torre. Chegam a tempo de impedir a fuga de Alori, que levava as espadas dos doze pares então adormecidos. O traidor é enforcado.

Sabendo que Lançon está quase sem defensores, os Pares abandonam a torre usando um barco e chegam à cidade, anunciando trazer o corpo de Jehan, abatido por Rolando. Na verdade este se fingia de morto na liteira. Quando as portas são abertas, os franceses atacam e ocupam a principal torre de Lançon. Jehan é avisado do ocorrido e volta à sua cidade para assediar os franceses. Um mágico a seu serviço, Malaquim, consegue infiltrar-se na torre onde os pares estão, rouba-lhes as espadas e raspa o bigode e a barba de Basin. Um duelo é travado entre Basin e Malaquim, na qual o primeiro é vitorioso e recupera as espadas dos companheiros.

Os pares decidem solicitar o apoio de Carlos Magno e Basin parte como mensageiro. Novamente como peregrino ele engana Jehan e seus homens, rouba o melhor cavalo de seu adversário e vai para Paris. Durante a viagem Basin deve enfrentar um antigo companheiro de roubos, Servein, e o duque Archambaut que tentava tomar-lhe a esposa em Genebra. Chegando à corte, avisa o imperador das dificuldades dos pares. O clã de Ganelon, parente de Jehan, a partir daí, tenta impedir o apoio real aos franceses assediados. Doze traidores disfarçados de peregrinos se apresentam na corte de Carlos e dizem que os pares já conquistaram Lançon e estavam em Roma. Basin parte para Roma para confirmar a história e descobre a falsidade. Orienta um peregrino verdadeiro a avisar o imperador e vai ajudar Rolando e os outros. Após matar um grupo de ladrões, usa o produto do roubo que fizeram a uns mercadores para apresentar-se no acampamento de Jehan e, depois, penetrar na torre com alimentos para os doze pares.

Enquanto isso o verdadeiro peregrino chega a Paris e avisa o imperador da traição feita contra ele e os pares. Os falsos peregrinos, desmascarados, são executados e a hoste parte para Lançon. No decorrer da marcha os Ganelidas entram em contato com Jehan e orientam este a atacar e matar o imperador para tornar-se rei da França. Uma primeira batalha dá a vitória a Carlos Magno, graças às ações do fiel Berart de Mondidier. Hardres, 
parente de Ganelon, é acusado de traição por ajudar os inimigos do rei e é marcado um duelo judicial. Chegando a hoste a Lançon, os doze pares conseguem se reunir ao imperador. Trava-se o duelo entre Hardres e Berart. A intervenção de Jehan permite a fuga do traidor para Lançon. Ganelon continua orientando os adversários de Carlos. Graças a isso o imperador é capturado quando caçava e é levado para a cidade de seus inimigos. Basin se oferece para libertar o rei e parte, disfarçado como peregrino. Quando é aceito dentro da cidade, assume o papel de um louco para poder enganar seus adversários e ser recebido na corte. Uma última traição de Ganelon é impedida por Olivier que guarda a saída do acampamento francês.

Na cidade, Carlos é tratado com respeito por Jehan. O imperador reconhece Basin no salão do palácio. Na hora de dormir, Jehan tenciona velar o imperador junto com outros fiéis, para impedir a ação do mágico, que ele não sabe já estar ali dentro. Basin faz encantamentos para os cavaleiros dormirem e, depois, junto com Carlos, leva Jehan para fora dos muros, deixando o portão aberto para a hoste franca. Lançon é conquistada e os detentores de feudos devem reconhecer o domínio de Carlos. Isoré é recompensado com a própria Lançon. O imperador retorna a Paris, levando Jehan, que seria metido em uma prisão na qual passaria o resto de seus dias. 
APÊNDICE VI

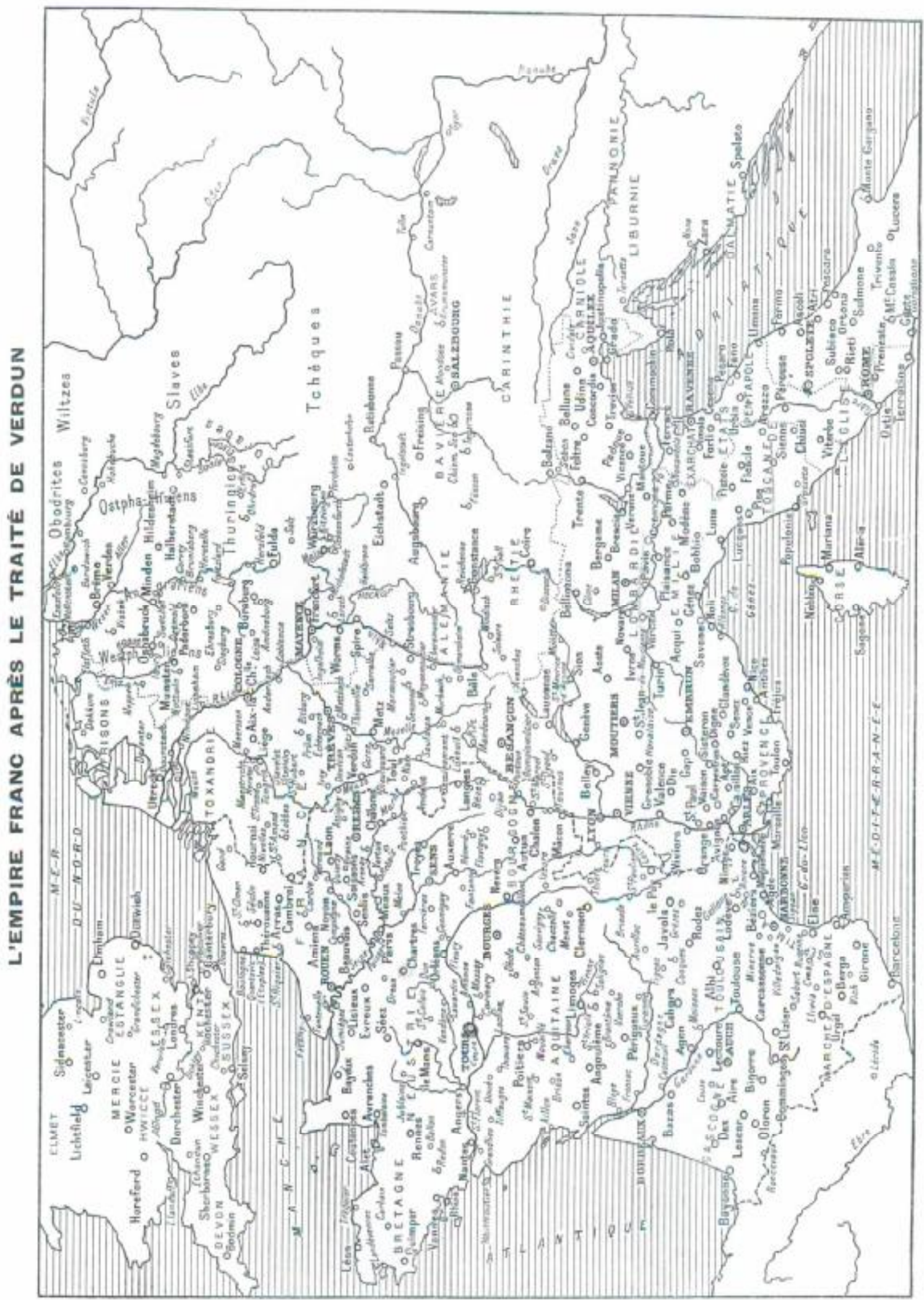

L'Empire Franc après le Traité de Verdun (843)

CALMETTE, Joseph. Atlas historique, II - Le Moyen Age. Paris : PUF, 1959, p. IV 


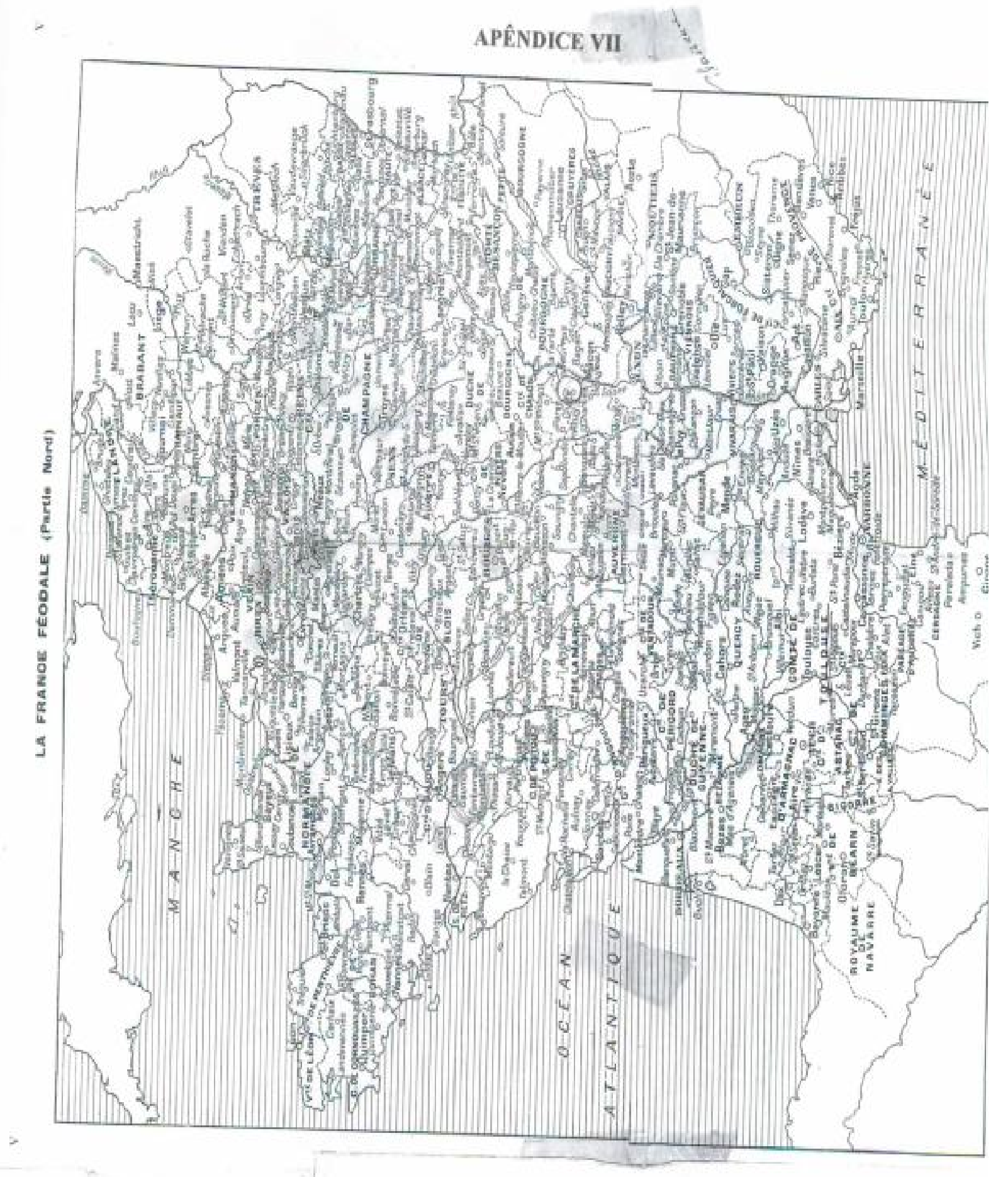

